UNIVERSIDADE DE SÃO PAULO

FACULDADE DE ECONOMIA, ADMINISTRAÇÃO E CONTABILIDADE DEPARTAMENTO DE CONTABILIDADE E ATUÁRIA

PROGRAMA DE PÓS-GRADUAÇÃO EM CONTROLADORIA E CONTABILIDADE

EMILIO MALTEZ ALVES FILHO

Cultura organizacional de cursos de Ciências Contábeis: um estudo em duas universidades públicas 
Prof. Dr. Marco Antonio Zago

Reitor da Universidade de São Paulo

Prof. Dr. Adalberto Américo Fischmann

Diretor da Faculdade de Economia, Administração e Contabilidade

Prof. Dr. Gerlando Augusto Sampaio Franco de Lima

Chefe do Departamento de Contabilidade e Atuária

Prof. Dr. Luiz Paulo Lopes Fávero

Coordenador do Programa de Pós-Graduação em Controladoria e Contabilidade 
EMILIO MALTEZ ALVES FILHO

\section{Cultura organizacional de cursos de Ciências Contábeis: um estudo em duas universidades públicas}

Tese apresentada ao Programa de PósGraduação em Controladoria e Contabilidade do Departamento de Contabilidade e Atuária, da Faculdade de Economia, Administração e Contabilidade, da Universidade de São Paulo, como requisito parcial para a obtenção do título de Doutor em Ciências.

Orientador: Prof. Dr. Luís Eduardo Afonso

Coorientador: Prof. Dr. Gilberto de Andrade Martins

\section{Versão Corrigida}

(Versão original disponível na Biblioteca da Faculdade de Economia, Administração e Contabilidade)

\section{SÃo PAULO}


Autorizo a reprodução e divulgação total ou parcial deste trabalho, por qualquer meio convencional ou eletrônico, para fins de estudo e pesquisa, desde que citada a fonte.

FICHA CATALOGRÁFICA

Elaborada pela Seção de Processamento Técnico do SBD/FEA/USP

Alves Filho, Emilio Maltez

Cultura organizacional de cursos de Ciências Contábeis: um estudo em duas universidades públicas / Emilio Maltez Alves Filho. -São Paulo, 2016.

$174 \mathrm{p}$.

Tese (Doutorado) - Universidade de São Paulo, 2016.

Orientador: Luis Eduardo Afonso.

Co-orientador: Gilberto de Andrade Martins.

1. Cultura organizacional 2. Ciências Contábeis 3 . Ensino superior 4. Etnografia 5. Técnica do discurso do sujeito coletivo I. Universidade de Săo Paulo. Faculdade de Economia, Administraçăo e Contabilidade. II. Titulo.

$\mathrm{CDD}-658.1$ 
Aos meus pais (in memoriam) Teresa M. Silva Lima Alves, pela sua ternura e exemplo de mãe e Emilio Maltez Alves pelo seu espírito humanitário, conduta impecável e pai exemplar. A minha irmã caçula Denise (in memoriam) um ser humano lindo que tão cedo nos deixou. 



\section{AGRADECIMENTOS}

Incialmente, eu agradeço ao Princípio Criador do Cosmos, Grande Arquiteto do Universo, por todas as bênçãos alcançadas ao longo da minha vida e, em especial, pela conclusão desta etapa. Agradeço aos meus pais (in memoriam) que souberam semear princípios e valores que continuam a me inspirar e que estão presentes na minha mente e no coração.

Agradeço a DEUS pela benção de ser pai de duas adoráveis, lindas e saudáveis fillhas, Taisa e Tassiana, ambas profissionais atuantes na área de saúde, das quais muito me orgulho.

Agradeço a minha companheira Dora pelo apoio nos quatro anos em que ficamos afastados da companhia um do outro, mas que muito me inspirou com seu amor e compreensão.

Agradeço, em especial, ao Prof. Luís Eduardo Afonso pela oportunidade da orientação criteriosa e brilhante, e pelo convívio e aprendizado ao longo do trabalho. Agradeço também ao Prof. Gilberto de Andrade Martins por sua orientação, convívio e incentivo, desde a sua primeira disciplina no primeiro semestre de 2012, além de mais duas ao longo do programa. $\mathrm{O}$ aprendizado propiciado pela interação e cumplicidade forjou laços fecundos de amizade.

Agradeço aos docentes do departamento com quem tive o a oportunidade do aprendizado e do convívio, ao cursar as suas disciplinas nos períodos de créditos, que agora fazem parte das nossas lembranças: Gilberto A. Martins, Gerlando A. S. F. de Lima, L. Nelson Carvalho, Bruno Salotti, Luís P. Fávero, Welinton Rocha, Edgard Cornachione e J. R. Kassai.

Agradeço ainda aos demais professores da FEA com quem tive a oportunidade de me relacionar, trazendo-me contribuições com suas experiências: Fábio Frezatti, Andson Braga, Márcio Borinelli, Luciane Reginato, Patricia Varela e João Paccez. Agradeço ainda, pelos mesmos motivos, aos docentes do DCIS/UEFS: Herval Moura, Artur R. Nascimento, Dilson Cerqueira, Vagner Silva, Tania Azevedo, Luiz Ivan, Ione Aparecida e Fernando Gentil.

Agradeço também ao Prof. Fernando Lefevre, com quem tive o privilégio de apreender a Técnica do Discurso do Sujeito Coletivo, criada e desenvolvida por ele e sua esposa.

Agradeço ao coordenador do programa, Prof. Luiz Paulo Fávero e seu pessoal de apoio. Agradeço a Marcia Bento e suas colegas. Também agradeço a Belinda Oliveira e, ao pessoal da Fotocopiadora da FEA3 e da biblioteca (Giselle e Rafael) pelo suporte técnico.

Agradeço à UEFS nas pessoas do Pró-reitor de Administração e Finanças da UEFS, Prof. Rossine Cerqueira da Cruz, o coordenador do DINTER, Prof. Rosembergue Valverde pelo empenho e dedicação e aos apoios da Secretaria da PPPG. Agradeço ainda à Universidade do Estado da Bahia (UNEB) por poder participar deste programa, pelo apoio da Bolsa PAC e também aos meus colegas do Campus DCHT em Camaçari/Bahia.

Agradeço aos meus colegas do Dinter Bahia, com os quais pudemos vivenciar momentos riquíssimos de convivência, aprendizado, ansiedade, cumplicidade, intercâmbio de ideias e auxílios mútuos, enfim, o meu fraternal abraço a: Ana Lúcia Santos, Edmilson Patrocínio de Sousa, José Renato Sena, Iracema Aragão, Marcia Figueiredo d'Souza, Raimundo Nonato Lima Filho, Robson Braga e Sandra Cerqueira Mattos.

Para não correr o risco de omitir o nome de alguém, agradeço, enfim, a todos que indiretamente contribuíram para a realização deste trabalho. O meu muito obrigado. 

"Cultura é equilíbrio intelectual, reflexão crítica, senso de discernimento, aborrecimento frente a qualquer simplificação, a qualquer maniqueísmo, a qualquer parcialidade".

Norberto Bobbio 



\section{RESUMO}

Alves Filho, Emilio Maltez. (2016). Cultura organizacional de cursos de Ciências Contábeis: um estudo em duas universidades públicas

O objetivo geral deste trabalho foi compreender o atual estágio da Cultura Organizacional Acadêmica (COA) em duas Instituições de Ensino Superior (IES) brasileiras, visando identificar possíveis relações entre a cultura e os resultados decorrentes do desempenho dessas IES. A revisão da literatura contemplou as principais teorias sobre cultura organizacional (CO), principalmente as abordagens de Schein (2009), Denison et al. (2012) e Hofstede (2003), além de referenciais empíricos de pesquisadores que se basearam nas abordagens desses autores. A metodologia utilizada teve predomínio qualitativo, com base em etnografia, elementos da observação participante e uso de entrevistas, tanto em profundidade quanto semiestruturadas, que foram gravadas para posterior transcrição e edição. Para o tratamento dos conteúdos das entrevistas, utilizou-se a técnica do Discurso do Sujeito Coletivo (DSC) de Fernando Lefevre e Ana Lefevre (2012), com o emprego do software Qualiquantisoft. O campo empírico abrangeu dois cursos de Ciências Contábeis de duas universidades públicas estaduais, contatadas por acessibilidade. Estes cursos foram o do Departamento de Contabilidade e Atuária da Faculdade de Economia, Administração e Contabilidade da Universidade de São Paulo [FEA/USP] e o do Departamento de Ciências Sociais Aplicadas da Universidade Estadual de Feira de Santana, na Bahia [DCIS/UEFS]. Foram entrevistados 10 docentes do curso da FEA/USP e oito docentes do curso do DCIS/UEFS. Também foi aplicado um questionário para 122 alunos do curso da FEA/USP e 84 alunos do curso do DCIS/UEFS. Os resultados principais são que o atual estágio da COA nos dois cursos das duas IES apresenta-se em polos diametralmente opostos, ou seja, há força na COA do curso da USP, que se reflete na responsabilidade de manter, no presente, os padrões alcançados no passado, e buscar aumentar essa alta referência e visibilidade do curso no país e na América Latina, com orientação estratégica para internacionalização. Em contrapartida, a situação do curso da UEFS é oposta, na qual, de acordo com seus docentes, ele atravessa um período de queda na sua COA, a qual se mantém basicamente adormecida frente às mudanças do ambiente externo, que se reflete em queda dos níveis de qualidade do curso e dos níveis de motivação dos alunos e docentes. Em síntese, os resultados decorrentes do desempenho do curso têm forte dependência da força e solidez de sua COA, materializada na responsabilidade, qualificação e empenho de seus membros (docentes e gestores).

Palavras-chave: Cultura organizacional. Ciências Contábeis. Ensino superior. Etnografia. Técnica do Discurso do Sujeito Coletivo 


\begin{abstract}
Alves Filho, Emilio Maltez. (2016). Organizational culture of Accounting courses: a study in two public universities.
\end{abstract}

The aim of this study was to understand the current state of Academic Organizational Culture (AOC) in two Higher Education Institutions (HEIs), to identify possible relationships between culture and the results arising from the performance of these HEIs. The literature review included the major theories of organizational culture (OC), especially the approaches to Schein (2009), Denison et al. (2012) and Hofstede (2003), and empirical references of researchers that were based on the approaches of these authors. The methodology used was predominantly qualitative, based on ethnography, participant observation elements and use of interviews, both in depth as semistructured that were recorded for later editing and transcription. For the treatment of the content of the interviews, we used the technique of the Collective Subject Discourse (CSD) of Fernando Lefevre and Ana Lefevre (2012) with the use of Qualiquantisoft software. The empirical field covered two Accounting courses at two state universities, contacted by accessibility. These courses were the Department of Accounting and Actuarial Science at the Faculty of Economics, Management and Accountancy at the University of São Paulo [FEA/USP] and the Department of Applied Social Sciences at the State University of Feira de Santana in Bahia [DCIS/UEFS]. 10 professors of the course of FEA / USP and eight professors of the course of DCIS/UEFS were interviewed. Also a questionnaire was applied to 122 students of the FEA / USP and 84 students of the DCIS/UEFS. The main results are that the current stage of the AOC in both courses of the two HEIs comes in diametrically opposite poles, that is, there is strength in the AOC of USP course, which is reflected in the responsibility of maintaining, at present, the achieved standards in the past and seek to increase this high reference and visibility of progress in the country, Latin America, with strategic direction for internationalization. In contrast, the current situation at UEFS is opposite, in which, according to their teaching, is being through a falling period of its AOC, that remains essentially dormant facing the external environment changes, which is reflects the fall of current quality and motivation levels of students and professors. In summary, the results from the course of the performance have a strong dependence of the strength and solidity of its AOC materialized responsibility, skills and commitment of its members (professors and administrators).

Keywords: Organizational culture. Accounting. Higher education. Ethnography. Collective Subject Discourse technique. 


\section{LISTA DE FIGURAS}

Figura 1. Visão esquemática da integração entre os ambientes acadêmico e externo 19

Figura 2. Distribuição das IES no Brasil em 2012, por regiões geográficas ......................... 36

Figura 3. Camadas ou níveis de cultura de Schein. .................................................. 44

Figura 4. Modelo conceitual de Pesquisa de Cultura........................................................ 54

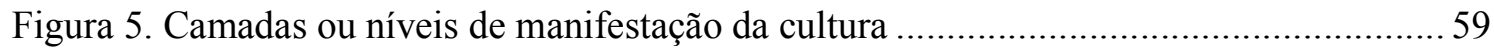

Figura 6. Interação dos elementos do modelo de culturas do Departamento Intercolegial de Atletismo.

Figura 7. Modelo de quatro forças da cultura segundo Denison e Mishra (1995) ................. 76

Figura 8. Quadro conceitual do estudo de Uprety e Chhetri (2014).................................. 78

Figura 9. Camadas de uma cultura organizacional que apoia a inovação............................ 79

Figura 10. Distribuição dos respondentes por semestre letivo (FEA/USP) ....................... 120

Figura 11. Inserção no mercado de trabalho dos alunos do curso (FEA/USP) ..................... 121

Figura 12. Distribuição dos respondentes por semestre letivo (DCIS/UEFS) .................... 150

Figura 13. Inserção no mercado de trabalho dos alunos do curso (DCIS/UEFS) ................. 150 


\section{LISTA DE TABELAS}

Tabela 1 Evolução de docentes do Ensino Superior no Brasil $(1990$ - 2011) ....................... 18

Tabela 2 Cursos de Contabilidade Stricto Sensu no Brasil até o ano 2000 ...........................20

Tabela 3 Evolução dos docentes do Ensino Superior no Brasil (1990-2011) ........................ 21

Tabela 4 Resultados do Enade - Cursos de Ciências Contábeis em IES públicas e Privadas

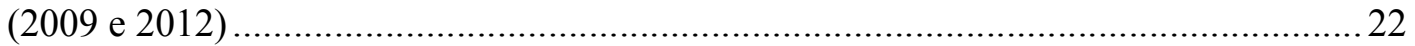

Tabela 5 Resultados do Exame de Suficiência (2011-2015).............................................. 23

Tabela 6 Evolução do Ensino Superior no Brasil: IES por setor, total geral de cursos e total de

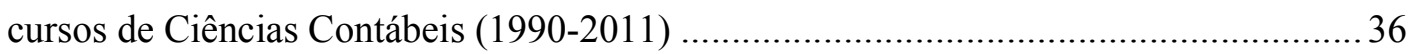

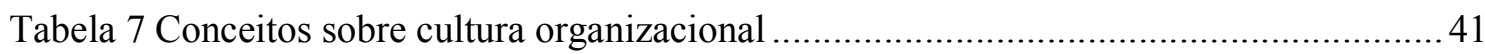

Tabela 8 Dimensões e Questões da Cultura Organizacional segundo Schein (2009) ............. 46

Tabela 9 Etapas para avaliação da cultura organizacional .................................................. 51

Tabela 10 Categorias de pesquisa nas organizações......................................................... 52

Tabela 11 Dimensões, vertentes e aspectos da Cultura Organizacional ...............................56

Tabela 12 Passos-chave e considerações sobre a cultura organizacional ............................. 61

Tabela 13 Conhecimentos, práticas e valores docentes ................................................. 68

Tabela 14 Uma síntese das práticas e/ou competências docentes ....................................... 70

Tabela 15 Um quadro conceitual para Cultura Organizacional ...................................... 72

Tabela 16 Questões iniciais para investigação da cultura no Departamento Intercolegial de

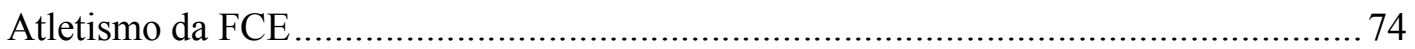

Tabela 17 Informações sobre local, data, hora e duração das entrevistas (março-maio/2015) 92

Tabela 18 Dimensões da COA, Categorias e quantidade de IC .........................................96

Tabela 19 Questionário para survey com alunos do curso de Ciências Contábeis das IES .....97

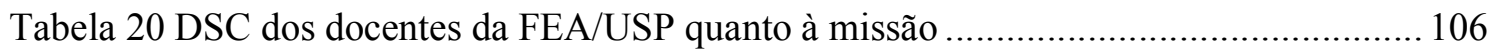

Tabela 21 DSC dos docentes da FEA/USP quanto à adaptabilidade externa ...................... 108

Tabela 22 DSC dos docentes da FEA/USP quanto à integração interna ............................ 112

Tabela 23 DSC dos docentes da FEA/USP quanto à consistência ...................................... 116

Tabela 24 Resultados do survey com os alunos do curso de Ciências Contábeis da FEA/USP

Tabela 25 Escolhas dos alunos quanto às mudanças no curso da FEA ............................... 124

Tabela 26 Síntese comparativa entre as percepções de docentes e discentes sobre a COA do curso de Ciências Contábeis da FEA/USP 
Tabela 27 DSC dos docentes do curso no DCIS/UEFS quanto à missão do curso................ 134

Tabela 28 DSC dos docentes do curso do DCIS/UEFS quanto à adaptabilidade externa..... 137

Tabela 29 DSC dos docentes do curso do DCIS/UEFS quanto à integração interna ............ 141

Tabela 30 Conceitos obtidos no Enade pelo curso de Ciências Contábeis do DCIS/UEFS na

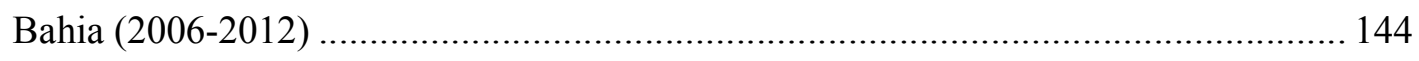

Tabela 31 DSC dos docentes do curso do DCIS/UEFS quanto à consistência ..................... 145

Tabela 32 Survey com os alunos do curso de Ciências Contábeis do DCIS/UEFS.............. 151

Tabela 33 Escolha dos alunos quanto a mudanças no curso (DCIS/UEFS) ......................... 153

Tabela 34 Síntese comparativa entre as percepções dos docentes e discentes sobre a COA do curso de Ciências Contábeis do DCIS/UEFS - BA................................................. 154 


\section{SUMÁRIO}

1 INTRODUÇÃO

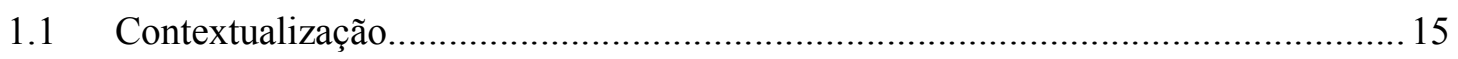

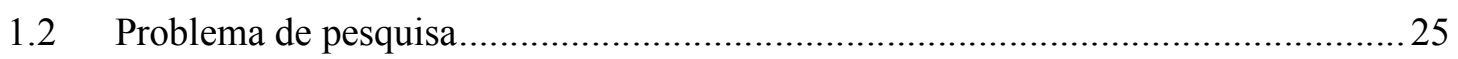

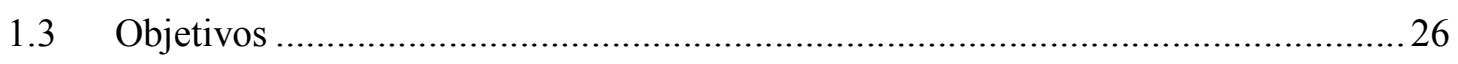

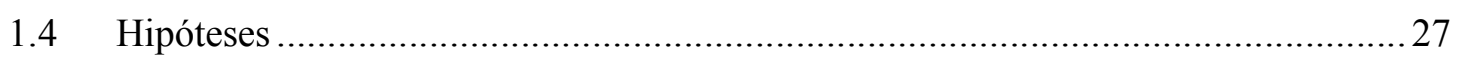

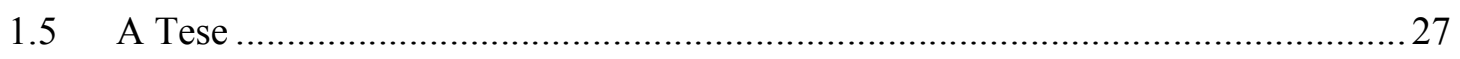

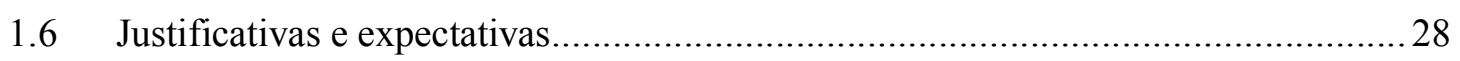

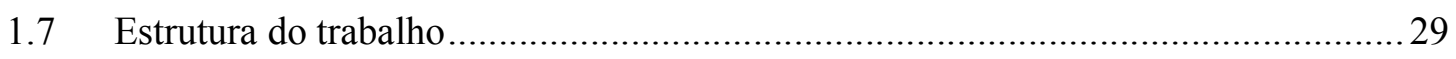

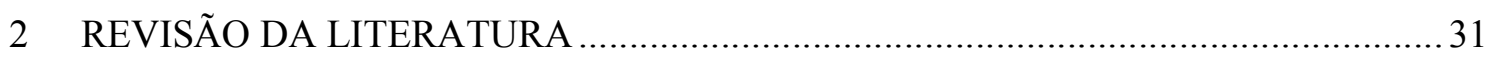

2.1 A universidade no Modelo Jesuítico (ou Escolástico) ................................................31

2.2 Evolução do Ensino Superior (ES) no Brasil, com destaque para o período 1960-

2013

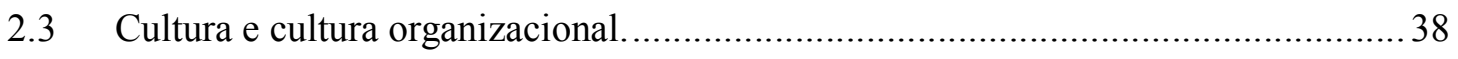

2.3.1 Cultura Organizacional segundo Edgar H. Schein (2009) ................................ 43

2.3.2 Cultura organizacional segundo Denison, Hooijberg, Lane, \& Lief (2012) ......53

2.3.3 Cultura Organizacional segundo Hofstede (2003) ………………...................58

2.4 Práticas docentes associadas à cultura organizacional acadêmica ............................64

2.5 Literatura empírica sobre cultura organizacional ............................................... 71

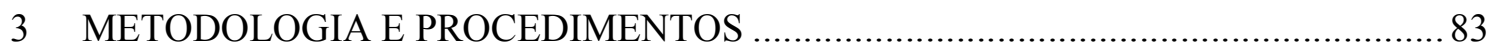

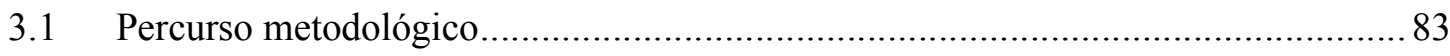

3.2 Caracterização da população e acesso às IES. …………………………………..... 85

3.3 A técnica do Discurso do Sujeito Coletivo (DSC). ................................................ 89

3.4 Trabalho de campo................................................................................... 91 
4 RESULTADOS .

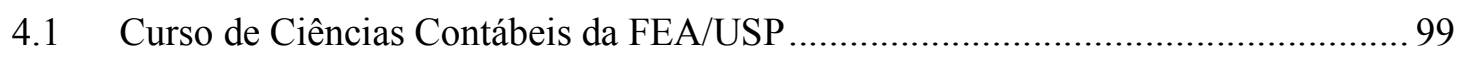

4.1.1 Breve histórico do curso de Ciências Contábeis da FEA/USP ........................ 99

4.1.2 Resultado das entrevistas com os docentes da FEA/USP ........................... 103

4.1.3 Resultados e análise do levantamento junto aos alunos do curso de Ciências

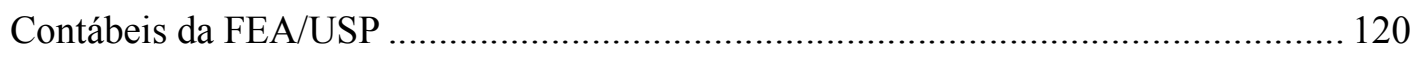

4.1.4 Síntese da comparação das percepções dos docentes e discentes (FEA/USP) 125

4.2 Curso de Ciências Contábeis do DCIS/UEFS .................................................. 129

4.2.1 Breve histórico do Curso de Ciências Contábeis do DCIS/UEFS .................. 129

4.2.2 Resultados das Entrevistas com os docentes do DCIS/UEFS...................... 132

4.2.3 Resultados e análise do levantamento com os alunos do curso de Ciências

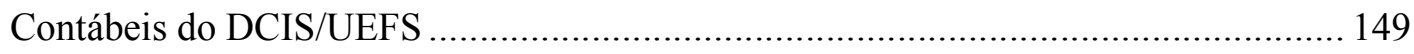

4.2.4 Síntese da comparação das percepções dos docentes e discentes (DCIS/UEFS) .. 154

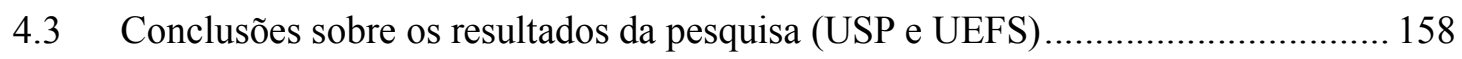

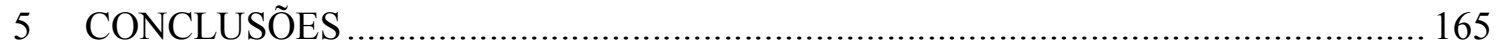

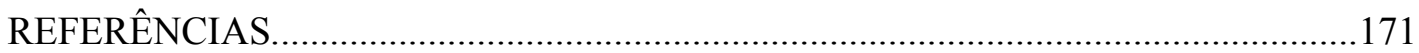





\section{INTRODUÇÃO}

\subsection{Contextualização}

O Brasil possui distintas culturas com múltiplas facetas regionais, costumes e tradições variadas. Contudo, é um país cujo nível educacional é muito baixo se comparado a outros. De acordo com o Instituto Nacional de Estudos e Pesquisas Educacionais Anísio Teixeira [INEP] (2015a), a Organização para a Cooperação e Desenvolvimento Econômico (OCDE) aponta, em sua última pesquisa de 2012, que o Brasil ${ }^{1}$ está na $58^{\mathrm{a}}$ posição entre os 65 países analisados, embora tenha conseguido uma significativa melhora, de 2003 para 2012, nas áreas de Matemática, Leitura e Ciências. Essa pesquisa avalia o desempenho de alunos com 15 anos de idade do nível médio nas referidas áreas. Abaixo do Brasil estão Argentina, Tunísia, Jordânia, Catar, Indonésia e Peru.

Até meados do século XX, o Brasil era muito atrasado em matéria de educação, quando comparado a países da América Latina (Castro \& Leite, 2006). As primeiras universidades neste continente foram instituídas no século XVI no Peru e em Santo Domingo, na República Dominicana, enquanto no Brasil a implantação de cursos superiores só veio a acontecer no século XIX, após a vinda de Dom João VI com a família real. Ainda assim, esses cursos eram limitados a escolas profissionais, abrangendo apenas Medicina, Direito e Engenharia Civil.

Percebe-se, porém, que a cultura de organizações acadêmicas no Brasil, como também em outros países, ainda guarda fortes resquícios do modelo de universidade implantada no século XII. Pimenta e Anastasiou (2011) observam que as práticas e modos de ensino-aprendizagem, presentes nas atuais universidades, contêm ainda fortes traços culturais do chamado modelo jesuítico, originado do método escolástico, do mesmo século XII, e do modus parisiensis, como era denominado na Universidade de Paris.

Complementam as autoras que, durante as aulas, cabia aos alunos fazer as anotações sobre os temas expostos pelos professores para, em seguida, serem memorizadas em exercícios. Como os textos apresentados pelos docentes suscitavam dúvidas, surgiam indagações por parte dos alunos, que os professores buscavam esclarecer, surgindo as disputationes (debates).

\footnotetext{
${ }^{1}$ A pesquisa é feita com estudantes de todas as regiões do país, assim como nos demais países.
} 
Demo (2004) aponta que, com base nesse modelo, que, supostamente, ainda sobrevive na maioria das Instituições de Ensino Superior (IES), não se aprende quase nada na universidade, em particular nas IES que apenas oferecem aulas; “[...] impera o mais atrasado instrucionismo, a reboque de didáticas medievais de mera reprodução de conhecimento, ignorando a própria pesquisa que nela se faz; [...] o emblema maior desse disparate é o horista, um professor inventado para só dar aula e pago só para isso" (p. 5). Demo conclui sobre esse atraso:

[...] O mundo gira, à velocidade cada vez mais estonteante, e a universidade sequer percebe ou faz de conta que não vê. As perplexidades invadem a vida da sociedade e do mercado, mas a universidade proclama as mesmas certezas. Só ela acredita nisso. Nem percebe que está ficando sozinha, porque, na sua empáfia, jura que não precisa de ninguém. Ela se basta, quando na verdade é apenas autofágica. Enquanto tudo à volta está em redemoinho, ela continua acreditando que, para mudar o mundo, basta deixar tudo como sempre foi. Haja aula! (Demo, 2004, p. 148).

Ademais, baseado no citado modelo jesuítico, parece razoável supor que ainda haja resquícios de traços culturais daquela época no ambiente organizacional de boa parte das atuais IES e em seus respectivos componentes. Ou seja, nos dias de hoje ainda remanescem elementos da cultura organizacional das universidades que se originaram no século XII.

Por outro lado, Perkins (1972) comenta que os séculos XII e XIII viram a fundação sequencial dos centros mais ilustres de aprendizagem: Paris, Cambridge, Oxford, Bolonha e Salamanca, entre eles. Concebidas como locais para a interação conveniente de mestres, estudiosos e estudantes, o autor ressalta que essas instituições de ensino geraram as principais características das culturas organizacionais universitárias, tais como se conhecem atualmente. Assim como o aumento da estrutura universitária levou a um crescimento da administração, o incremento do corpo docente e do currículo também levou à organização do corpo docente (Perkins, 1972). Surgiram então duas funções organizacionais dentro da universidade, que se revelaram como críticas: a administrativa e a acadêmica, tornando as atribuições do corpo docente e da administração intimamente relacionadas.

Embora Castro e Leite (2006) tentem justificar que a primeira universidade brasileira foi a Universidade de São Paulo [USP], criada em 1934, e que trouxe renomados acadêmicos 
franceses, alemães e italianos, Alfonso-Goldfarb e Ferraz (2002, p. 10) fazem a seguinte observação sobre a USP: “[...] uma das primeiras universidades brasileiras e a primeira a manter dedicação exclusiva, pressupondo ensino associado à pesquisa, esse centro tinha como uma de suas metas, desde a fundação, desenvolver a ciência e criar os quadros necessários de cientistas no país". Com o pós-guerra e o aumento da percepção de que o país precisava dar um salto no seu desenvolvimento, houve forte mudança nas políticas públicas ligadas à educação (Castro \& Leite, 2006).

De 1960 a 1990, o Brasil foi o país que teve o maior crescimento em número de IES e cursos no continente, com a criação de pelo menos uma universidade federal em cada estado, no que foi acompanhado pelo setor privado. Nos anos 1990, esse aumento tornou-se mais acelerado, embora Castro e Leite (2006) afirmem que este segundo momento foi liderado pelo setor privado.

Pereira (1997) argumenta que, na verdade, essa mudança de posicionamento no setor público decorreu da reforma do Estado nos anos 1990, tornando-o um “[...] Estado SocialLiberal do século vinte-e-um” (p. 60). Acrescenta o autor que, dentre outras ações, o Estado passou a delimitar suas funções, reduzindo o seu tamanho, principalmente em termos de pessoal, através de programas de privatização e terceirização. O Estado saía do seu papel de centralizador, provedor e gestor para tornar-se um Estado avaliador e incentivador.

Portanto, a partir dos anos 1990, para atender à expansão mais acelerada das ofertas de cursos de ensino superior (ES), notadamente pelo setor privado, as IES deste segmento passaram a contratar, nas palavras de Cunha (2004), 'professores improvisados', bastando, geralmente, um curso de especialização lato sensu. Esta expansão dos docentes pode ser vista na Tabela 1, que permite também mostrar o período (entre 1997 e 1999) em que o crescimento dos docentes do setor privado se torna mais acentuado que o do setor público.

Enquanto o número de docentes no setor público cresceu 60,3\% entre 1999 e 2011, no setor privado esse aumento foi de 145,1\% no mesmo período. Em 2011, o número de docentes do setor privado era $75,7 \%$ superior ao do setor público. De acordo com o INEP (2014a), percebe-se uma significativa predominância de oferta de vagas nos cursos de 
Administração, Direito e Ciências Contábeis nesse mesmo período em relação aos demais cursos.

Tabela 1

Evolução de docentes do Ensino Superior no Brasil (1990 - 2011)

\begin{tabular}{cccccc}
\hline Anos & IES Públicas & \% & IES Privadas & \% & Total Geral \\
\hline $\mathbf{1 9 9 0}$ & 71.904 & 54,6 & 59.737 & 45,4 & $\mathbf{1 3 1 . 6 4 1}$ \\
$\mathbf{1 9 9 1}$ & 72.123 & 54,2 & 61.012 & 45,8 & $\mathbf{1 3 3 . 1 3 5}$ \\
$\mathbf{1 9 9 3}$ & 72.594 & 52,9 & 64.562 & 47,1 & $\mathbf{1 3 7 . 1 5 6}$ \\
$\mathbf{1 9 9 5}$ & 76.268 & 52,5 & 69.022 & 47,5 & $\mathbf{1 4 5 . 2 9 0}$ \\
$\mathbf{1 9 9 7}$ & 84.591 & 51,0 & 81.373 & 49,0 & $\mathbf{1 6 5 . 9 6 4}$ \\
$\mathbf{1 9 9 9}$ & 80.883 & 46,5 & 92.953 & 53,5 & $\mathbf{1 7 3 . 8 3 6}$ \\
$\mathbf{2 0 0 1}$ & 81.300 & 39,8 & 122.806 & 60,2 & $\mathbf{2 0 4 . 1 0 6}$ \\
$\mathbf{2 0 0 3}$ & 88.795 & 34,9 & 165.358 & 65,1 & $\mathbf{2 5 4 . 1 5 3}$ \\
$\mathbf{2 0 0 5}$ & 98.033 & 33,5 & 194.471 & 66,5 & $\mathbf{2 9 2 . 5 0 4}$ \\
$\mathbf{2 0 0 7}$ & 108.828 & 34,3 & 208.213 & 65,7 & $\mathbf{3 1 7 . 0 4 1}$ \\
$\mathbf{2 0 0 9}$ & 113.030 & 33,2 & 227.787 & 66,8 & $\mathbf{3 4 0 . 8 1 7}$ \\
$\mathbf{2 0 1 1}$ & 129.631 & 36,3 & 227.787 & 63,7 & $\mathbf{3 5 7 . 4 1 8}$ \\
\hline
\end{tabular}

FONTE: Dados adaptados a partir do INEP (2014a)

A educação contábil, em particular, encontra-se em crise não apenas no Brasil, mas em nível global (Turner, Reed \& Greiman, 2011; Marshall, Dombrowski, Garner, \& Smith, 2010; Adler, Withing, \& Wynn-Williams, 2008; Lin, Xiong, \& Liu, 2005; Albrecht \& Sack, 2000). A grande quantidade de novas leis, normas e regras contábeis postas em vigor gera demasiadas informações que dificultam a sua apreensão e internalização pelos docentes das IES dos cursos de Contabilidade. Estes não conseguem, rapidamente, apreendê-las e disponibilizá-las para aprendizagem e compreensão pelos estudantes da área (Turner et al., 2011).

De acordo com estes autores, mesmo com as 150 horas adicionais de educação contábil, tornadas obrigatórias para obtenção do licenciamento CPA (Certified Public Accountant ${ }^{2}$ ), seria impraticável ensinar e assimilar tudo o que há para aprender. Ao longo dos anos, em face de mudanças no mercado profissional, atualizações têm sido recomendadas e realizadas nos currículos de Contabilidade, porém ainda são insuficientes para reduzir esse hiato.

\footnotetext{
${ }^{2}$ Registro obrigatório nos EUA para o contador possuir fé pública e assinar demonstrações contábeis.
} 
Parece haver, no referido hiato, uma significativa defasagem cultural e temporal entre os paradigmas do ambiente acadêmico interno (gestão, docentes, práticas e currículo) e os do ambiente externo às IES (Turner et al., 2011). Mais especificamente, quanto à complexidade $\mathrm{e}$ mutação da realidade socioeconômica global e das inovações tecnológicas geradas pelos negócios em geral. A Figura 1 apresenta uma visão sistêmica do macroambiente formado pelo ambiente acadêmico e o ambiente externo, no qual está o mercado profissional.

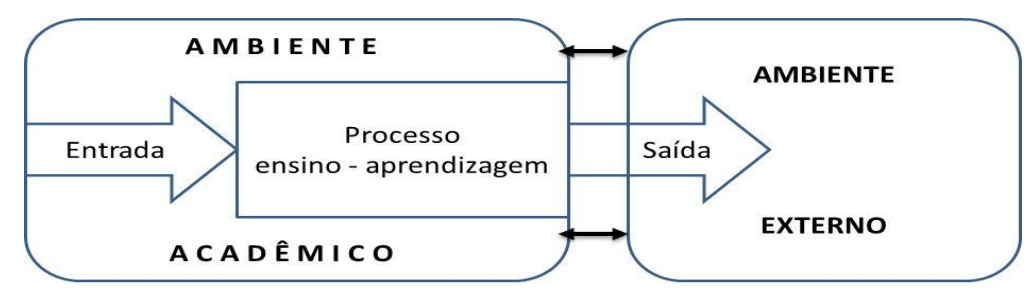

Figura 1. Visão esquemática da integração entre os ambientes acadêmico e externo

Na Figura 1, considera-se que a estrutura física e a infraestrutura necessária da IES (departamentos, secretarias, biblioteca, entre outros) já existam. Supõe-se, ainda, que estes elementos estejam em condições de operação. Assim, busca-se apresentar os componentes do processo ensino-aprendizagem que são os seus elementos de entrada, entre eles: a gestão organizacional e acadêmica, docentes, currículos, práticas, metodologias e recursos de ensino, normas internas e de órgãos normatizadores, estudantes, informações do mercado, entre outros.

Esses elementos de entrada e o próprio processo ensino-aprendizagem formam a cultura organizacional acadêmica (COA), ou seja, a 'caixa preta' em que, supostamente, deveria ocorrer o período de desenvolvimento e conversão do aluno em potencial profissional e pensador, principal 'produto' de saída do sistema, capaz de se posicionar de forma autônoma no mercado e na sociedade. Fechando o ciclo, este mercado fornece novos inputs realimentando o sistema. A COA, portanto, está presente nas ações dos membros das IES que a fazem funcionar e continuar seguindo na sua missão principal de formar profissionais e cidadãos potencialmente aptos para atuar no mercado profissional e na sociedade em geral.

Há, particularmente na área contábil, uma lacuna entre o ensino superior e a sua prática profissional, ou seja, ensino versus mercado profissional (Marshall et al., 2010). Estes autores 
questionam se a educação contábil não deveria ser ministrada por contadores, com sólida experiência profissional, ao invés de doutores e mestres, com predomínio acadêmico.

O aparente declínio de qualidade na educação, nos cursos de graduação em Ciências Contábeis, é parcialmente explicado pela expansão significativa do número desses cursos, que passou de 194 (1986) para 578 (2001), 910 (2006) e 1398 (2013) (Andere \& Araújo, 2008; Ministério da Educação [MEC], 2014). Este incremento não foi acompanhado, proporcionalmente, pelo crescimento da oferta de cursos de pós-graduação stricto sensu em Contabilidade, que ocorreu de forma gradativa e lenta. Até o ano 2000, havia apenas oito cursos de pós-graduação stricto sensu em Contabilidade no Brasil, conforme apresentado na Tabela 2.

Tabela 2

Cursos de Contabilidade Stricto Sensu no Brasil até o ano 2000

\begin{tabular}{l|l|l}
\hline \multicolumn{1}{c|}{ Instituição } & \multicolumn{1}{c}{ Cidade/UF } & \multicolumn{1}{c}{ Tipo/Ano } \\
\hline $\begin{array}{l}\text { Universidade de São Paulo - USP } \\
\text { Pontifícia Universidade Católica de São } \\
\text { Paulo - PUC/SP }\end{array}$ & São Paulo - SP & $\begin{array}{l}\text { Mestrado - 1970 } \\
\text { Doutorado - 1978 }\end{array}$ \\
\hline $\begin{array}{l}\text { Universidade do Vale do Rio dos Sinos - } \\
\text { UNISINOS }\end{array}$ & São Paulo - SP & Mestrado - 1978 \\
\hline $\begin{array}{l}\text { Programa Multi-Institucional e Inter- } \\
\text { Regional - UnB/UFPB/UFRN/UFPE }\end{array}$ & $\begin{array}{l}\text { Capitais dos Estados e } \\
\text { Distrito Federal }\end{array}$ & Mestrado 1998 \\
\hline $\begin{array}{l}\text { Universidade Federal do Rio de Janeiro - } \\
\text { UFRJ }\end{array}$ & Rio de Janeiro - RJ & Mestrado - 1999 \\
\hline $\begin{array}{l}\text { Centro Universitário Álvares Penteado - } \\
\text { FECAP }\end{array}$ & São Paulo - SP & Mestrado - 1999 \\
\hline $\begin{array}{l}\text { Fund. Inst. Capixaba de Pesq. em Cont. } \\
\text { Econ. e Finanças - FUCAPE }\end{array}$ & Vitória/ES & Mestrado - 2000 \\
\hline
\end{tabular}

Nota. Fonte: Adaptado de Peleias, I. R., Silva, G. P. D., Segreti, J. B., \& Chirotto, A. R. (2007). Evolução do ensino da contabilidade no Brasil: uma análise histórica. Revista Contabilidade \& Finanças, 30(número especial), 19-32.

No período em que ocorre a citada expansão mais acelerada do ensino superior, então liderada pelo setor privado (anos 1990), observa-se que, em 1978, havia apenas três cursos, dois de mestrado e um de doutorado. Após 20 anos, passaram a ser ofertados mais cinco cursos de mestrado, todos nas regiões sudeste e sul do Brasil, exceto o Programa MultiInstitucional e Inter-Regional - UnB/UFPB/UFRN/UFPE ${ }^{3}$. Devido à evolução muito lenta e ao número reduzido de cursos, o fluxo de mestres e doutores que se qualificaram nesse

\footnotetext{
${ }^{3}$ UnB: Universidade de Brasília. As demais são universidades federais, respectivamente, da Paraíba, do Rio Grande do Norte e de Pernambuco.
} 
período parece ter sido insuficiente para atender proporcionalmente ao aumento do número de cursos, o que pode ter gerado um acréscimo na demanda para docentes com, no máximo, especialização lato sensu.

A partir de final dos anos 1990, houve um aumento da oferta de cursos de pós-graduação stricto sensu. Busca-se mostrar, na Tabela 3, a consequência da evolução desta oferta, separando os docentes graduados e especialistas dos mestres e doutores (1990-2011). Depois de 1999, o número de mestres e doutores passa a superar o de docentes com especialização.

Tabela 3

Evolução dos docentes do Ensino Superior no Brasil (1990-2011)

\begin{tabular}{cccccc}
\hline Anos & $\begin{array}{c}\text { Graduados até } \\
\text { Especialistas }\end{array}$ & $\mathbf{\%}$ & $\begin{array}{c}\text { Mestres e } \\
\text { Doutores }\end{array}$ & \% & Total \\
\hline $\mathbf{1 9 9 0}$ & 86.949 & 66,1 & 44.692 & 33,9 & $\mathbf{1 3 1 . 6 4 1}$ \\
\hline $\mathbf{1 9 9 1}$ & 86.377 & 64,9 & 46.758 & 35,1 & $\mathbf{1 3 3 . 1 3 5}$ \\
\hline $\mathbf{1 9 9 3}$ & 86.487 & 63,1 & 50.669 & 36,9 & $\mathbf{1 3 7 . 1 5 6}$ \\
\hline $\mathbf{1 9 9 5}$ & 87.600 & 60,3 & 57.690 & 39,7 & $\mathbf{1 4 5 . 2 9 0}$ \\
\hline $\mathbf{1 9 9 7}$ & 95.068 & 57,3 & 70.896 & 42,7 & $\mathbf{1 6 5 . 9 6 4}$ \\
\hline $\mathbf{1 9 9 9}$ & 88.050 & 50,7 & 85.786 & 49,3 & $\mathbf{1 7 3 . 8 3 6}$ \\
\hline $\mathbf{2 0 0 1}$ & 94.819 & 46,5 & 109.287 & 53,5 & $\mathbf{2 0 4 . 1 0 6}$ \\
\hline $\mathbf{2 0 0 3}$ & 110.378 & 43,4 & 143.775 & 56,6 & $\mathbf{2 5 4 . 1 5 3}$ \\
\hline $\mathbf{2 0 0 5}$ & 124.096 & 42,4 & 168.408 & 57,6 & $\mathbf{2 9 2 . 5 0 4}$ \\
\hline $\mathbf{2 0 0 7}$ & 131.123 & 41,4 & 185.918 & 58,6 & $\mathbf{3 1 7 . 0 4 1}$ \\
\hline $\mathbf{2 0 0 9}$ & 127.501 & 37,4 & 213.316 & 62,6 & $\mathbf{3 4 0 . 8 1 7}$ \\
\hline $\mathbf{2 0 1 1}$ & 113.315 & 31,7 & 244.103 & 68,3 & $\mathbf{3 5 7 . 4 1 8}$ \\
\hline
\end{tabular}

Nota. Fonte: Adaptado de INEP (2014a). Censo da Educação Superior.

Em 2011 o número de mestres e doutores já superava os demais em 115,4\%. Embora este incremento na qualificação possa ter contribuído para o aumento da qualidade no ensino superior, outras ações na área educacional já vinham sendo conduzidas pelo governo federal por meio do MEC, em particular, na área de avaliação.

Essas ações de avaliação educacional só se concretizaram nos anos 1990, despertando o interesse de pesquisadores em distintos campos do conhecimento, como Educação, Economia e Psicologia (Freitas, 2012). Os principais programas foram: Sistema Nacional de Avaliação da Educação Básica (SAEB), em 2005; Exame Nacional do Ensino Médio (ENEM), 1998; e o 
Exame Nacional de Cursos (ENC), em 1996, que foi substituído posteriormente, em 2004, por meio da Lei $10.861^{4}$, pelo Exame Nacional de Desempenho dos Estudantes (Enade).

Na avaliação do Enade, de acordo com o INEP (2012; 2013), os exames em 2009 e $2012^{5}$ apresentaram os resultados relacionados na Tabela 4 em número de cursos:

Tabela 4

Resultados do Enade - Cursos de Ciências Contábeis em IES públicas e Privadas (2009 e 2012)

\begin{tabular}{|c|c|c|c|c|c|c|c|c|c|c|c|c|}
\hline \multirow{3}{*}{ Conceito } & \multicolumn{4}{|c|}{ Cursos: IES Públicas } & \multicolumn{4}{|c|}{ Cursos: IES Privadas } & \multicolumn{4}{|c|}{ TOTAL } \\
\hline & \multirow[b]{2}{*}{$\mathbf{N}$} & \multirow{2}{*}{$\frac{2009}{\%}$} & \multicolumn{2}{|c|}{ e $\quad 2012$} & \multirow[b]{2}{*}{$\mathbf{N}$} & \multirow{2}{*}{$\begin{array}{c}2009 \\
\%\end{array}$} & \multirow{2}{*}{$\begin{array}{l}\mathbf{e} \\
\mathbf{N}\end{array}$} & \multirow{2}{*}{$\frac{2012}{(\%)}$} & \multirow[b]{2}{*}{$\mathbf{N}$} & \multirow{2}{*}{$\begin{array}{l}2009 \\
(\%)\end{array}$} & \multirow{2}{*}{$\begin{array}{l}\mathbf{e} \\
\mathbf{N} \\
\end{array}$} & \multirow{2}{*}{$\frac{2012}{(\%)}$} \\
\hline & & & $\mathbf{N}$ & $\%$ & & & & & & & & \\
\hline 1 & 3 & 2,6 & 3 & 2,2 & 13 & 2,1 & 14 & 1,8 & 16 & 2,2 & 17 & 1,8 \\
\hline 2 & 16 & 13,9 & 20 & 14,7 & 201 & 32,7 & 241 & 30,3 & 217 & 29,7 & 261 & 28,0 \\
\hline 3 & 43 & 37,4 & 56 & 41,2 & 304 & 49,4 & 371 & 46,6 & 347 & 47,5 & 427 & 45,8 \\
\hline 4 & 34 & 29,6 & 46 & 33,8 & 84 & 13,7 & 148 & 18,6 & 118 & 16,2 & 194 & 20,8 \\
\hline 5 & 19 & 16,5 & 11 & 8,1 & 13 & 2,1 & 22 & 2,8 & 32 & 4,4 & 33 & 3,5 \\
\hline Total & 115 & 100 & 136 & 100 & 615 & 100 & 796 & 100 & 730 & 100 & 932 & 100 \\
\hline
\end{tabular}

Nota. Fonte: Adaptado de INEP (2012). Resultados do ENADE de 2009; INEP (2013). Resultados do ENADE de 2012.

Com base nestas avaliações de 2009 e 2012, os cursos de Ciências Contábeis têm apresentado um predomínio do conceito 3, em uma escala de 1 a 5 , em linha com a performance dos cursos de Administração no mesmo período ${ }^{6}$. Em 2009 e 2012, estes eram $43,6 \%$ contra $47,5 \%$ e $44,5 \%$ contra $45,8 \%$ dos cursos de Ciências Contábeis (CCC), respectivamente (INEP, 2012; 2013). Neste curso (CCC), foram obtidos conceitos 4 e 5 apenas em 20,6\% e 24,3\%, no total, ligeiramente melhores que nos cursos de Administração, com $16,4 \%$ e $20 \%$ no período indicado (INEP, 2012; 2013).

Pelo Censo da Educação Superior (INEP, 2012; 2013) e Portal e-MEC (MEC, 2014), a quantidade de cursos de Ciências Contábeis passou de 1.028, em 2009, para 1.295, em 2012. Participaram do Enade, no período, 902 e 943 cursos, respectivamente, mas os cursos que conseguiram pontuação igual ou superior a 1 foram 730 e 932. Portanto, o número de cursos que não obtiveram o conceito mínimo de 1 foi bastante reduzido de 2009 para 2012.

\footnotetext{
${ }^{4}$ Esta lei instituiu o Sistema Nacional da Educação Superior (SINAES), que substituiu o ENC pelo Enade.

${ }^{5} \mathrm{O}$ Enade é realizado a cada ano, para uma seleção de cursos distintos. Contudo, de três em três anos, um curso específico é avaliado. O exame mais recente dos cursos de Contabilidade foi realizado em 2012. A partir deste ano os alunos ingressantes não participam mais da avaliação do Enade, mas apenas os concluintes.

${ }^{6}$ Os totais de cursos de Administração no período foram, respectivamente, de 1.414 e 1.897 . Destes, 617 e 836 obtiveram conceito 3 (três); e 232 e 375 obtiveram conceitos entre 4 e 5.
} 
AS IES públicas tiveram 46,1\% de seus cursos com conceitos entre 4 e 5, em 2009, caindo ligeiramente para 41,9\% em 2012. Já as IES privadas tiveram apenas 15,8\% de cursos com conceitos entre 4 e 5, em 2009, porém aumentaram para 21,4\% em 2012, sugerindo ter havido ligeira melhora no desempenho destas em relação às IES públicas.

Tabela 5

Resultados do Exame de Suficiência (2011-2015)

\begin{tabular}{lcc}
\hline Ano & Semestre & Aprovação (\%) \\
\hline 2011 & 1 & 30,9 \\
2011 & 2 & 58,3 \\
2012 & 1 & 47,3 \\
2012 & 2 & 26,1 \\
2013 & 1 & 35,6 \\
2013 & 2 & 43,1 \\
2014 & 1 & 49,4 \\
2014 & 2 & 41,7 \\
2015 & 1 & 54,5 \\
\hline
\end{tabular}

Nota. Fonte: Adaptado de Conselho Federal de Contabilidade [CFC] (2015). Agência de Notícias.

A Tabela 5 apresenta a evolução dos índices de aprovação nos Exames de Suficiência do CFC, os quais são realizados duas vezes por ano, a cada semestre. Seus indicadores são ainda incipientes para serem tomados como referência, tendo em vista que este exame só foi retomado em 2011, após suspensão em 2004. Ele indica que a aprovação média entre os que participaram dos últimos cinco exames foi de $43,5 \%$.

Para a melhoria desses indicadores de exames externos (Enade e o de Suficiência do CFC), as IES e os docentes têm grandes desafios a superar para aprimorar sua cultura acadêmica contábil, envolvendo conhecimentos, práticas e metodologias, além da elaboração de uma matriz curricular atualizada e dinâmica que propicie o aperfeiçoamento do processo ensinoaprendizagem face à realidade mutante e complexa. E as IES precisam adaptar a sua cultura organizacional para criar este ambiente. Para Cornachione (2004), “[...] os meios devem ser apropriados para os cenários e objetivos específicos da educação" (p. 4).

As ideias sobre cultura organizacional $(\mathrm{CO})$ já existiam em produções acadêmicas anteriores a 1980, porém foi nesta década que os estudos sobre CO se intensificaram e se 
popularizaram com muita rapidez (Freitas, 2012). Entre os pesquisadores sobre CO encontram-se Pettigrew (1979), Smircich (1983), Schein (1984, 1985, 1992, 2004, 2007, 2009), Davis (1984), Barney (1986), Ouchi (1988), Tierney (1988) e Ott (1989). Dentre estes, o mais citado na literatura sobre este tema é Edgar H. Schein (2009), que apresenta um conceito clássico para a expressão $\mathrm{CO}$ a partir dos membros da organização, que ele denomina grupo:

A cultura de um grupo pode [...] ser definida como um padrão de suposições básicas compartilhadas, que foi aprendido por um grupo à medida que solucionava seus problemas de adaptação externa e de integração interna. Esse padrão tem funcionado bem o suficiente para ser considerado como válido e, por conseguinte, para ser ensinado aos novos membros como o modo correto de perceber, pensar e sentir-se em relação a esses problemas. Em resumo, podemos pensar a cultura como a aprendizagem acumulada e compartilhada por determinado grupo, cobrindo os elementos comportamentais, emocionais e cognitivos do funcionamento psicológico de seus membros. [Itálicos nossos] (Schein, 2009, p. 16).

Acrescenta também o autor que a cultura tem sido definida pelos antropólogos para referirse aos costumes e rituais que as sociedades desenvolvem no curso de sua história, sendo que o aspecto mais intrigante da $\mathrm{CO}$, como conceito, talvez seja que ela indica os fenômenos que estão abaixo da superfície, que são poderosos em seus impactos quase invisíveis e contemplam um grau considerável de contradição. Schein (2009) comenta que a 'adaptação externa' compreende questões ligadas à sobrevivência, crescimento e adaptação da organização em seu ambiente, tanto externo quanto interno. Os elementos essenciais da adaptabilidade externa são: a) missão e estratégia; b) metas; c) meios; d) mensuração e e) correção. Estes elementos, bem como aqueles referentes à integração interna, apresentados em síntese na sequência, estão descritos com mais detalhes no capítulo de Revisão da Literatura desta tese.

De acordo com Schein $(2009$, p.103) “[...] se a função de um grupo é realizar tarefas que possibilitem sua adaptação ao ambiente externo, ele deve ser capaz de desenvolver e manter um conjunto de relacionamentos internos entre seus membros". A 'integração interna' permite, portanto, o funcionamento diário e a capacidade de a organização se adaptar e continuar aprendendo. Os seus elementos são: i) criar uma linguagem e categorias conceituais comuns; ii) definir as fronteiras do grupo e os critérios de inclusão e exclusão; iii) distribuir 
poder e status; iv) desenvolver normas de intimidade, amizade e afetividade; v) definir e alocar recompensas e punições; e vi) explicar o inexplicável: ideologia e religião.

Outra definição clássica de cultura organizacional é a de Ouchi (1988, p. 43):

A cultura organizacional consiste em um conjunto de símbolos, cerimônias e mitos que comunicam os valores e crenças subjacentes dessa organização a seus empregados. Estes rituais concretizam aquilo que, do contrário, seriam ideias esparsas e abstratas, dando-lhes vida de modo a que tenham significado e impacto para um novo empregado.

Geralmente há pontos comuns entre os conceitos formulados por pesquisadores desse tema (ver seção 2.3), principalmente, quanto ao conjunto de símbolos, mitos, heróis, crenças e valores subjacentes, rituais ou cerimônias que dão sentido à vida em grupo na organização. Outros conceitos e apreciações sobre cultura organizacional, incluindo modelos de cultura de grupos encontram-se descritos com mais detalhes na seção 2.2 da Revisão da Literatura.

As IES têm a sua cultura organizacional constituída de crenças, valores, normas internas e externas. Elas são emitidas pelos reguladores quanto às condições que cada curso deve adotar e seguir, tais como as políticas, métodos e recursos para o ensino, a gestão acadêmica e os demais sujeitos do processo ensino-aprendizagem, entre eles, os docentes e suas práticas, oriundas de sua trajetória acadêmica, profissional e pessoal. Porém muito pouco se sabe do que está subjacente à cultura organizacional das IES, principalmente o conjunto de valores e padrões básicos aprendidos e compartilhados por elas ao longo do tempo, além do modus operandi dos seus principais atores: a gestão, os docentes e suas práticas.

Sendo a IES uma organização, pode-se inferir que ela representa a capacidade coletiva de seus integrantes de produzir e agregar valor para a sociedade. Isto sugere que a cultura organizacional é um aspecto fundamental para o crescimento e sobrevivência das IES.

\subsection{Problema de pesquisa}

As reflexões e evidências apresentadas na seção anterior permitem destacar três aspectos fundamentais. Primeiro, a frágil pontuação da educação no Brasil ( $58^{\mathrm{a}}$ posição) entre os 65 países da pesquisa da OCDE, de acordo com o INEP (2015a). Segundo, a maioria dos cursos 
de Ciências Contábeis no Brasil obteve conceitos entre 1 e 3 no Enade (79,5\% em 2009 e 75,2\% em 2012), em linha com os cursos de Administração (83,6\% em 2009 e 80, 1\% em 2012), sugerindo fragilidade no ensino superior, pelo menos na área de Ciências Sociais Aplicadas; e no Exame de Suficiência do CFC, no período 2011 a 2015, a aprovação média foi de 43,5\%. Por fim, em terceiro, a relevante defasagem cultural e temporal entre os paradigmas dos inputs e outputs nos cursos de Ciências Contábeis. Consideram-se como inputs a própria COA do curso na IES (gestão e práticas docentes), conteúdos curriculares e normas regulatórias. Os outputs podem ser entendidos como a disponibilização de egressos (potenciais profissionais) e as alternativas de sua inclusão e posicionamento em um ambiente externo dinâmico e complexo.

Estes aspectos contribuíram para a formulação da questão que norteia este trabalho: Qual o atual estágio da cultura organizacional acadêmica em Instituições de Ensino Superior que mantêm cursos de graduação em Ciências Contábeis?

\subsection{Objetivos}

O objetivo geral deste trabalho é compreender o atual estágio da cultura organizacional acadêmica (COA) em algumas IES brasileiras que mantêm cursos de graduação em Ciências Contábeis, com o propósito de identificar possíveis relações de dependência entre esta cultura e os resultados decorrentes do desempenho dessas IES. A partir do objetivo geral, em sentido amplo, foram identificados e elaborados os seguintes objetivos específicos:

a) Compreender o que é cultura organizacional, com o objetivo de identificá-la em IES que mantêm cursos de graduação em Ciências Contábeis;

b) Pesquisar e identificar formas e caminhos para compreender, in loco, a cultura organizacional acadêmica existente nas IES selecionadas;

c) Pesquisar e identificar quais práticas docentes estão associadas com a mudança da COA nas IES que mantêm graduação neste curso;

d) Identificar alternativas que possam contribuir para o equilíbrio ou adequação entre a COA do curso nas IES e a constante mutação do ambiente profissional externo. 


\subsection{Hipóteses}

Segundo Martins e Theóphilo (2009), o termo hipótese era originalmente empregado para servir de base à demonstração da tese de um teorema. Esse termo possui o significado de uma suposição, conjectura ou uma antecipação de resposta para um problema. Em decorrência da complexidade e abrangência do problema de pesquisa, assim como dos objetivos do trabalho, julgou-se apropriado formular mais de uma hipótese.

Assim, foram formuladas as seguintes hipóteses de trabalho:

a) Quanto mais força e solidez tiver a COA do curso na IES, melhores deverão ser os seus resultados em termos de desempenho e visibilidade externa;

b) A cultura organizacional das IES públicas apresenta baixa adaptabilidade externa ${ }^{7}$, que se reflete em uma baixa integração interna ${ }^{8}$.

\subsection{A Tese}

Segundo Abbagnano (2007), o termo tese decorre dos textos lógicos de Aristóteles, nos quais existem dois significados principais: a) para designar o que o interlocutor apresenta no início de uma dissertação como uma assunção sua; e b) para designar uma proposição assumida como princípio. Esses dois significados conservaram-se na tradição filosófica. $\mathrm{O}$ primeiro encontra-se já em Platão, e, segundo tradição relatada por Diógenes Laércio, Protágoras teria sido o primeiro a mostrar como apoiar uma tese em argumentos.

Nessa mesma linha, Martins e Theóphilo (2009) observam que existem pelo menos dois sentidos marcantes para a expressão tese: a) identificar uma proposição formulada com o propósito de defendê-la em público; e 2) constituir a publicação que contém a tese.

A tese deste trabalho possui o enunciado a seguir:

\footnotetext{
7 A adaptabilidade externa compreende questões ligadas à sobrevivência, crescimento e adaptação da organização em seu ambiente, tanto externo quanto interno (Schein, 2009).

${ }^{8} \mathrm{~A}$ integração interna propicia o funcionamento diário e a capacidade de a organização se adaptar e continuar aprendendo (Schein, 2009).
} 
A cultura organizacional das IES que mantêm graduação em Ciências Contábeis encontra-se difusa em termos de direção, adaptabilidade externa e integração interna.

\subsection{Justificativas e expectativas}

Dentre as principais justificativas para a elaboração deste trabalho, podem-se destacar: i) a inquietação deste autor, enquanto docente e pesquisador, quanto ao modus operandi individual e coletivo do trabalho do professor, suas responsabilidades no ensino superior, em particular, nos cursos de Ciências Contábeis, além do papel da gestão deste curso; ii) a necessidade de compreender a 'caixa preta' da cultura organizacional acadêmica das IES que mantêm graduação em Ciências Contábeis; iii) a compreensão da cultura destas IES propiciará racionalizar os fatores que afetam questões de adaptabilidade externa, integração interna e de liderança, otimizando-os; iv) a análise e a gestão da cultura organizacional das IES servirá de base fundamental para um possível aprimoramento do curso, indicando caminhos que possam minimizar a defasagem cultural e temporal entre o profissional que se busca formar e aquele que o dinâmico mercado profissional demanda; v) trata-se de um tema bastante abordado no exterior, mas pouco explorado no Brasil; e vi) o uso de uma abordagem socioantropológica, pouco comum na pesquisa contábil.

Espera-se, também, que este trabalho possa despertar um novo olhar para as opções que as IES - ofertantes de cursos de graduação em Ciências Contábeis - venham a escolher para atualizar e adequar os elementos de entrada do processo ensino-aprendizagem com os de saída, demandados pelo complexo e mutante ambiente externo, favorecendo uma melhor inclusão dos egressos no mercado profissional. Como elementos de entrada, consideram-se os atores que fazem parte da cultura acadêmica, tais como a estrutura física de salas, recursos, a gestão, o currículo, os regimentos, os docentes com seus saberes, métodos e práticas, entre outros. E, como elementos de saída, compreendem-se os egressos e a qualidade do curso, representados não apenas pelos conceitos obtidos em exames e avaliações e pela imagem da IES na comunidade e na região, como também pela aptidão do egresso para o mercado profissional. 


\subsection{Estrutura do trabalho}

Além deste capítulo introdutório, este trabalho contém mais quatro capítulos. $\mathrm{O}$ segundo capítulo compreende uma revisão da literatura relevante, sendo subdivido em cinco seções descritas no preâmbulo do capítulo; o terceiro capítulo trata da metodologia e dos procedimentos utilizados. O quarto capítulo trata da análise e interpretação dos resultados da pesquisa. Por fim, no quinto capítulo são elaboradas as conclusões e considerações finais do trabalho. 


\section{REVISÃO DA LITERATURA}

Este capítulo está dividido em cinco seções. A seção 2.1 resgata traços culturais e operacionais da universidade no modelo jesuítico; a seção 2.2 trata da evolução do Ensino Superior (ES) no Brasil, no período entre 1960 e 2013; a seção 2.3 trata do tema cultura e cultura organizacional; a seção 2.4 aborda o tema das práticas docentes no ES associadas à cultura organizacional acadêmica das IES; e, por fim, a seção 2.5 apresenta referenciais empíricos sobre a implantação de modelos de cultura organizacional em organizações, com ênfase em IES, visando buscar uma linha de convergência para a escolha da abordagem teórica utilizada neste trabalho, apresentada no capítulo de metodologia.

\subsection{A universidade no Modelo Jesuítico (ou Escolástico)}

Embora tenha havido avanços consideráveis nos campos técnico e tecnológico, assim como nas tecnologias de gestão, nos séculos XX e no início deste novo milênio, a universidade e a educação, no sentido amplo, ainda carregam traços culturais do modelo europeu, implantado no século XII, como mencionado de forma preliminar na Introdução.

De acordo com Rait (2007), o século XII produziu na Europa uma renovação de interesses e um renascimento da aprendizagem, provocados parcialmente pela influência de grandes pensadores e pela descoberta de obras perdidas de Aristóteles. Este impulso resultou em um aumento no número de alunos que eram atraídos para as escolas onde notáveis mestres sucediam a grandes nomes do passado. Nas escolas de Paris havia grandes mestres da Filosofia e da Teologia, muito procurados por alunos de todas as partes da Europa.

Pimenta e Anastasiou (2011), ao analisar a historicidade da universidade no Brasil, destacam a influência e a identificação com pelo menos três modelos europeus: o jesuítico, o francês e o alemão. Estes tiveram predominância em épocas distintas na história da universidade, e seus traços culturais ainda estão presentes na época contemporânea.

Para construir o seu método ou modelo, os jesuítas basearam-se no método escolástico, vigente desde o século XII, e no modus parisiensis, denominação do método vigente na 
Universidade de Paris, porque foi nesta universidade que Inácio de Loyola e os demais jesuítas que fundaram a Companhia de Jesus fizeram seus estudos (Pimenta \& Anastasiou, 2011).

As principais características desses dois modelos convergiam para dois momentos fundamentais: a lectio, na qual havia uma leitura do texto a ser trabalhado e a sua interpretação pelo professor, que analisava as palavras, destacando as ideias e a sua comparação com outros autores; e a questio, que se baseava nas questões, tanto as feitas pelo professor aos alunos, quanto destes para o mestre (Pimenta \& Anastasiou, 2011).

Destaque-se que naquela época (século XII) ainda não existia a imprensa, portanto eram muito limitadas as cópias dos livros publicados, bem como custoso e lento o processo de reprodução. Os traços culturais e procedimentos operacionais do ensino daquela época são descritos a seguir.

Correia (1950) comenta que na lectio os mestres liam, fazendo a exposição do conteúdo dos textos, que eram acompanhados pelos estudantes em cópias depositadas pelo autor nas livrarias, cujo preço era atribuído pela universidade. A exposição consistia em definir e esclarecer os termos, seguida de um sumário dos pontos essenciais. As quaestiones eram formuladas e suas soluções estavam implícitas e sugeridas nas cópias dos textos. As leituras eram ordinárias quando feitas pelos doutores pela manhã; e extraordinárias quando feitas pelos mestres ou bacharéis pela tarde.

Comenta o autor que, ao contrário do que ocorria nas lições ordinárias, os estudantes podiam, nas lições extraordinárias, propor dúvidas e objeções visando a uma melhor compreensão da matéria. As disputationes (debates) podiam ser ordinárias e externas (abertas ao público). A disputatio ordinária era semanal e durava da manhã ao meio-dia ou até à tarde, se ocorresse aumento do número dos participantes. Um dos mestres formulava a tese a ser discutida, e os oponentes objetavam. Dois ou três bacharéis eram designados para esclarecer as objeções, tudo em forma silogística e em latim.

As disputationes externas, denominadas quolibet, realizavam-se na Páscoa e no Natal. Na Faculdade das Artes essas discussões ocorriam externamente ao campus e atraíam numerosa 
assistência. O mestre incumbido de debater a questão tinha como oponentes os designados numa lista. Tais discussões podiam durar vários dias e até mesmo uma semana. Essas árduas provas, junto com os exames a serem prestados, conduziam o estudante à conquista dos graus.

Os exames eram orais, realizados perante o Chanceler e seu júri, devendo o estudante responder com êxito a três ou quatro perguntas, sob pena de ser reprovado, devendo, neste caso, tornar a comparecer depois de um ano. Quando aprovados, obtinham o grau de bacharéis (baccalareius) (Correia, 1950).

Segundo Perkins (1972), tudo apareceu de forma primitiva nas primeiras universidades: a autoridade do governo, a importância dos professores e a administração. A organização dos estudos passou por desenvolvimento semelhante. A evolução dos conhecimentos exigidos resultou na divisão dos assuntos entre o trivium - gramática, lógica e retórica - e, na sequência, o quadrivium - aritmética, música, geometria e astronomia.

Desta origem simples, também surgiram os assuntos ligados à especialização, que se tornaram 'a ordem do dia', resultando na proliferação de palestras e cursos. O autor afirma que, por seu turno, esses estudos mais avançados necessitaram de organizações competentes para limitar e definir seu alcance. Assim, as faculdades e departamentos surgiram como subdivisões administrativas necessárias para cuidar das novas subdivisões acadêmicas. Outro aspecto contemporâneo é mencionado por Perkins (1972, p. 682):

Na universidade medieval, a aprendizagem não foi, no entanto, confinada à sala de aula. Estreitar conexões entre professor e aluno foi pensado e planejado por ser essencial para o desafio da aprendizagem; o desejo de reforçar esta conexão levou à instalação de residências onde o viver e o aprender eram passados de mão em mão. Embora de menor importância no continente, a faculdade residencial tornou-se o pivô do ensino universitário em Oxford e Cambridge, e ainda é uma parte fundamental do sistema universitário britânico. Essas precursoras das nossas faculdades residenciais atuais, assim como outros recursos da instituição medieval, tiveram como razão de ser a promoção do empreendimento de ensino-aprendizagem.

Assim, ainda podem ser observadas semelhanças entre o ensino atual e aquele vigente no século XII. As principais distinções concentram-se nas inovações de certos métodos e tecnologias ocorridas desde então, tanto nos campos da imprensa, gráfica, informática e telecomunicações, quanto na área de gestão e recursos educacionais, mas a essência 
(exposição, anotações, debates, memorização e avaliação) continuou semelhante. Até mesmo formas alternativas de estudo, envolvendo locais e níveis de conhecimento, e a necessidade de uma organização mais robusta surgiram como forma de melhor administrar as subdivisões dos níveis de estudos, para acompanhar e registrar contabilmente a evolução das universidades.

\subsection{Evolução do Ensino Superior (ES) no Brasil, com destaque para o período 1960- 2013}

O objetivo desta seção é apresentar uma síntese da evolução do ES no Brasil no período citado, destacando a ampla expansão liderada pelo setor privado, que provocou uma queda na qualidade deste nível de ensino no país, e as ações do governo federal visando à avaliação e regulação das IES. No preâmbulo foi apresentado um breve contexto para justificar aspectos da época da implantação do ES no Brasil, que ainda permanecem em vigor.

Segundo Cunha (2004), o ES brasileiro era estatal na época do Império e centralmente controlado. Este padrão foi rompido na República, quando o formato do Estado foi adaptado à federação dos poderes regionais. Afirma o autor que o então ideário positivista, que preferia o ES deixado ao livre jogo do mercado, foi importante para esse fim. Entretanto, a influência e o poder detidos pela elite profissional da época (médicos, engenheiros e advogados) fizeram com que as IES herdadas do Império permanecessem estatais.

Paralelamente, os positivistas inventaram o modelo brasileiro de credenciamento, até hoje em vigor, que consistia no estabelecimento do registro acadêmico, nas repartições federais, dos diplomas das profissões regulamentadas por lei. Este procedimento somente poderia ser feito por IES (estaduais ou privadas) que tivessem o mesmo currículo das federais e fossem supervisionadas pelo ministério competente (Cunha, 2004).

Segundo Castro e Leite (2006, p.146), até meados do século XX o Brasil era “equilibradamente atrasado em matéria de educação. Pouquíssimas escolas primárias e quase nada de universidades”. Só com o período de reconstrução e prosperidade do pós-guerra o país se conscientizou da necessidade de formação de lideranças e pessoal qualificado para propiciar o salto do desenvolvimento, principalmente o industrial e o tecnológico. 
Acrescentam os autores que entre 1960 e 1990, basicamente, não houve um país sulamericano que tivesse crescimento tão acentuado no ES como o Brasil. Neste período, liderado pelo setor público, foi aberta pelo menos uma universidade em cada estado brasileiro, mas o setor privado acompanhou permanentemente esta expansão, que mudou fortemente o quadro da educação superior. A expansão dos campi até 1980 foi feita pelo governo federal; a partir de então, a expansão do ES foi liderada pelo setor privado.

Cunha (2004) defende a tese de que nas duas décadas de regime militar (1964 a 1985) houve aproximações políticas de empresários do ensino com os governos militares, propiciando a representação majoritária destes nos conselhos de educação, inclusive no federal. Assim, representando a maioria, eles passaram a legislar em causa própria. O autor acrescenta que o resultado final de tamanha expansão foi a desvalorização dos diplomas de ES de graduação, tanto material quanto simbolicamente. Porém, ao invés de reduzir, como se supunha, aumentou a sua demanda e a dos títulos subsequentes: o mestrado e o doutorado.

De 1980 a 1990, segundo o INEP (2014a), as IES públicas - que eram maioria, 75 unidades contra 19 IES privadas - passaram a ser minoria, com 222 unidades, enquanto as IES privadas passaram de 19 para 698 unidades, ou seja, um acréscimo de 679 IES em apenas dez anos. Castro e Leite (2006) afirmam que na década de 1990 o ES continuou a crescer, mas esta segunda onda, além de ter sido mais acelerada, passou a ser liderada pelo setor privado, devido à mudança de prioridades do setor público. De acordo com Pereira (1997), a mudança nas políticas públicas, em função da reforma do Estado, passou a privatizar e descentralizar algumas funções, incluindo a área de ES, o que provocou uma reconfiguração nesse segmento. Devido à finalidade de lucro do setor privado, coube a este sustentar o crescimento.

A Tabela 6 apresenta os números relativos à evolução da quantidade de IES por setor, totais de cursos de ES no Brasil e totais de cursos de Ciências Contábeis, no período de 1990 a 2011. Pode-se observar que, em 21 anos, o crescimento das IES privadas foi significativo (199\%) se comparado ao das IES públicas (28\%). Quanto ao número de cursos, o aumento foi mais acelerado ainda: em 10 anos, 158\%; e nos 10 anos seguintes, mais 150\%. De 1986 a 2013, de acordo com os dados da seção 1.1, o número de cursos de Ciências Contábeis cresceu de 194 para 1.398, ou seja, um aumento maior do que sete vezes. 
Tabela 6

Evolução do Ensino Superior no Brasil: IES por setor, total geral de cursos e total de cursos de Ciências Contábeis (1990-2011)

\begin{tabular}{lrlllllllllll}
\hline \multicolumn{1}{c}{ Anos } & $\mathbf{1 9 9 0}$ & $\mathbf{1 9 9 1}$ & $\mathbf{1 9 9 3}$ & $\mathbf{1 9 9 5}$ & $\mathbf{1 9 9 7}$ & $\mathbf{1 9 9 9}$ & $\mathbf{2 0 0 1}$ & $\mathbf{2 0 0 3}$ & $\mathbf{2 0 0 5}$ & $\mathbf{2 0 0 7}$ & $\mathbf{2 0 0 9}$ & $\mathbf{2 0 1 1}$ \\
\hline IES: & & & & & & & & & & & & \\
- Públicas & 222 & 222 & 221 & 210 & 211 & 192 & 183 & 207 & 231 & 249 & 245 & 284 \\
- Privadas & 696 & 671 & 652 & 684 & 689 & 905 & 1.208 & 1.652 & 1.934 & 2.032 & 2.069 & 2.081 \\
$\quad$ Total & $\mathbf{9 1 8}$ & $\mathbf{8 9 3}$ & $\mathbf{8 7 3}$ & $\mathbf{8 9 4}$ & $\mathbf{9 0 0}$ & $\mathbf{1 . 0 9 7}$ & $\mathbf{1 . 3 9 1}$ & $\mathbf{1 . 8 5 9}$ & $\mathbf{2 . 1 6 5}$ & $\mathbf{2 . 2 8 1}$ & $\mathbf{2 . 3 1 4}$ & $\mathbf{2 . 3 6 5}$ \\
Total Cursos: & & & & & & & & & & & & \\
Brasil & $\mathbf{4 . 7 1 2}$ & $\mathbf{4 . 9 0 8}$ & $\mathbf{5 . 2 8 0}$ & $\mathbf{6 . 2 5 2}$ & $\mathbf{6 . 1 3 2}$ & $\mathbf{8 . 8 7 8}$ & $\mathbf{1 2 . 1 5 5}$ & $\mathbf{1 6 . 4 5 3}$ & $\mathbf{2 0 . 4 0 7}$ & $\mathbf{2 3 . 4 8 8}$ & $\mathbf{2 7 . 8 2 7}$ & $\mathbf{3 0 . 4 2 0}$ \\
Contábeis & $\mathbf{2 4 2}$ & $\mathbf{2 6 2}$ & $\mathbf{2 9 9}$ & $\mathbf{3 5 2}$ & $\mathbf{3 8 7}$ & $\mathbf{4 5 9}$ & $\mathbf{5 7 8}$ & $\mathbf{7 0 1}$ & $\mathbf{8 1 8}$ & $\mathbf{9 4 0}$ & $\mathbf{1 . 0 2 8}$ & $\mathbf{1 . 2 4 1}$ \\
\hline
\end{tabular}

Nota. Fonte: Adaptado de INEP (2014a). Censo da Educação Superior; MEC (2014). Dados sobre a quantidade de cursos de Contabilidade no Brasil por Estado.

${ }^{a}$ O número referente a 1990 de 'Contábeis' foi estimado com base no crescimento médio anual dos últimos 21 anos.

Com base em INEP (2014b), havia 2.416 IES em 2012, sendo 304 do setor público e 2.112 do setor privado. A sua distribuição por região geográfica pode ser vista na Figura 2.

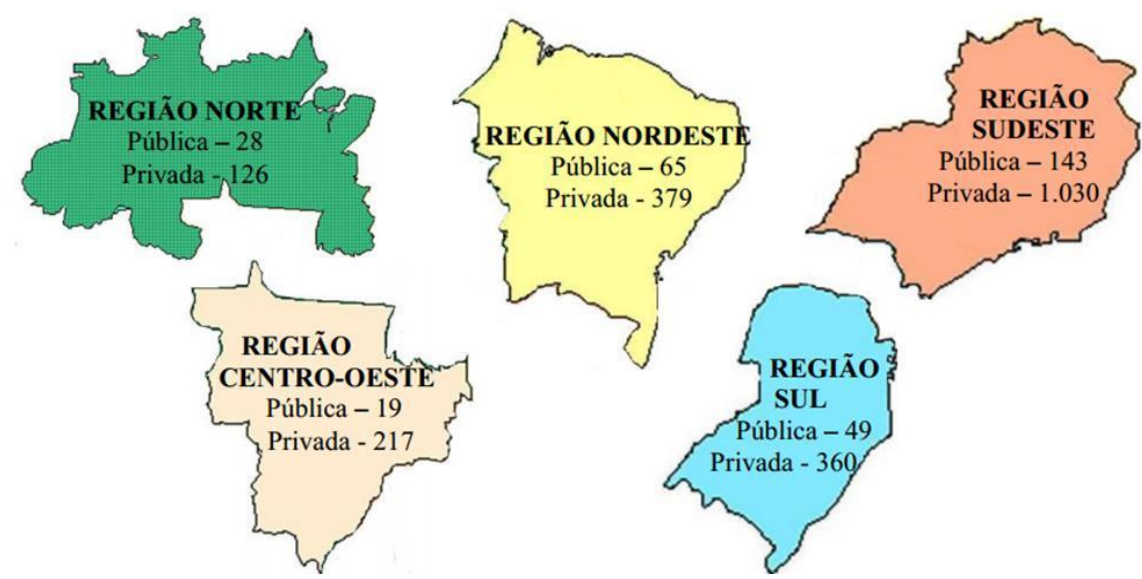

Figura 2. Distribuição das IES no Brasil em 2012, por regiões geográficas

Fonte: INEP (2014b). Palestra sobre Resultados do Censo da Educação Superior 2012

As regiões que mais se destacam em termos de quantidade de IES são as regiões Sudeste, Nordeste e Sul. Há 257 IES públicas nestas três regiões, ou 84,5\% do total, que é de 304, enquanto existem 1.769 IES privadas, ou 83,8\% do total, que é de 2.112 .

Embora a Tabela 6 aponte evidências de forte expansão das IES privadas sobre as IES públicas entre 1990 a 2011, o fato de haver um número expressivo de IES privadas comparativamente às IES públicas não é um aspecto isolado do Brasil. Segundo McCowan 
(2007), as instituições privadas estão crescendo em número e tamanho em todo o mundo e se tornando mais diversificadas, afastando-se dos modelos filantrópicos e religiosos tradicionais.

McCowan (2007) acrescenta que, nas últimas décadas, países do continente sul-americano passaram de pequenos sistemas públicos de elite para sistemas diversificados, em que as instituições privadas desempenham um papel fundamental. Uma minoria de IES privadas abriga também elites ricas, mas a ampla quantidade de estudantes de baixa renda tornou-se alvo crescente destas IES, por não conseguirem ser aprovados nos processos seletivos das universidades públicas.

O período de maior expansão das IES, iniciado em meados da década de 1980 e descrito anteriormente, resultou na implantação de políticas de regulação e avaliação do Sistema de Ensino Superior (SES) no Brasil. De acordo com Santos (2012), essas políticas serviram de apoio à implantação de instrumentos de avaliação e regulação das IES, entidades partícipes do SES. Esses instrumentos, segundo a autora, foram desenvolvidos para criar indicadores de qualidade do ensino. Entre esses instrumentos está o Censo da Educação Superior (CES), que passou a mensurar e divulgar anualmente estatísticas relativas ao ES, para subsidiar a sistematização das políticas de regulação, avaliação e fiscalização dessas entidades.

Barreyro e Rothen (2008) comentam que as duas principais concepções adotadas foram elaboradas por comissões federais do MEC. O embrião desta política teve origem em 1983 com o Programa de Avaliação da Reforma Universitária (PARU); depois, em 1985, com o relatório da Comissão Nacional de Avaliação do Ensino Superior (CONAES) chamado 'Uma Nova Política para a Educação Superior Brasileira'; em 1986, com o relatório do Grupo Executivo para Reformulação da Educação Superior Brasileira (GERES); e em 1993, com o Programa de Avaliação Institucional das Universidades Brasileiras (PAIUB).

Em 1995, por meio da Lei $n^{\circ}$ 9.131/95, foi instituído o Exame Nacional de Cursos (ENC), conhecido como "Provão", e, finalmente em 2004, com a Lei n ${ }^{\circ}$ 10.861/04, foi constituído o Sistema Nacional de Avaliação da Educação Superior (Sinaes) e o Exame Nacional de Desempenho dos Estudantes (Enade). A avaliação do ES passa, desde então, a ser um componente central na política de regulação do ES brasileiro (Barreyro \& Rothen, 2008). 


\subsection{Cultura e cultura organizacional.}

Nesta seção são expostas as principais correntes que tratam dos temas "cultura" e "cultura organizacional", seus conceitos mais conhecidos, além da seleção de três abordagens teóricas sobre o tema principal que se destacam. São enfatizados seus aspectos gerais, a estrutura sobre a qual se apoiam, sua relevância e aplicabilidade. Esta seção visa, principalmente, servir de referencial para pesquisar as Instituições de Ensino Superior (IES).

Abbagnano (2007, p. 225) define cultura da seguinte forma:

Esse termo tem dois significados básicos. No primeiro e mais antigo, significa a formação do homem, sua melhoria e seu refinamento. $O$ segundo significado indica $o$ produto dessa formação, ou seja, o conjunto dos modos de viver e de pensar cultivados, civilizados, polidos, que também costumam ser indicados pelo nome de civilização.

Segundo Choudhry, Fang e Mohamed (2007), a cultura é considerada a totalidade dos padrões de comportamento socialmente transmitidos, artes, crenças e muitos outros processos considerados a expressão de um determinado período, classe, comunidade ou população. Já DaMatta (1986, p. 123) apresenta o seguinte conceito:

Cultura é, em Antropologia Social e Sociologia, um mapa, um receituário, um código através do qual as pessoas de um dado grupo pensam, classificam, estudam e modificam o mundo e a si mesmas. É justamente porque compartilham de parcelas importantes deste código (a cultura) que um conjunto de indivíduos com interesses e capacidades distintas, e até mesmo opostas, transforma-se num grupo e podem viver juntos sentindose parte de uma mesma totalidade. Podem, assim, desenvolver relações entre si porque a cultura lhes forneceu normas que dizem respeito aos modos, mais (ou menos) apropriados de comportamento diante de certas situações.

As organizações são parte da sociedade. Portanto, sendo um segmento de sua cultura, são consideradas subculturas. Quando existe um grupo que não compartilha dos valores e da missão de uma organização, esse grupo forma uma contracultura (Motta, 2008). Assim, as “[..] culturas, subculturas e contraculturas são constituídas de valores, crenças e pressupostos básicos, ritos, rituais e cerimônias, histórias e mitos, tabus, heróis e anti-heróis, normas, formas de comunicação, sagas, lendas e outros símbolos e conjuntos simbólicos” (p. 20). 
Desde o início da década de 1980, a quantidade de pesquisas sobre o tema "cultura organizacional" tem crescido significativamente (Fleury, 1996), principalmente nos Estados Unidos e União Europeia. Segundo a autora, a cultura organizacional pode ser:

[...] concebida como um conjunto de valores e pressupostos básicos expresso em elementos simbólicos, que em sua capacidade de ordenar, atribuir significações, construir a identidade organizacional, tanto agem como elemento de comunicação e consenso, como ocultam e instrumentalizam as relações de dominação (Fleury, 1996, p. 22).

Freitas (2007), em linha com Fleury (1996), afirma que os estudos sobre cultura organizacional se massificaram na década de 1980 e se popularizaram rapidamente, embora parte de suas ideias estivesse presente em produção acadêmica anterior a esta data. Uma característica do mundo contemporâneo, incluindo o acadêmico, é o dinamismo e a rapidez das mudanças e a necessidade de reavaliações permanentes nas organizações. É natural, portanto, que haja uma produção, basicamente em série, de novos estudos sobre o tema que tragam novas contribuições e perspectivas de análise da cultura organizacional.

Por outro lado, Freitas (2007) faz uma reflexão crítica ao perceber nas grandes organizações, cientes da sua cultura, uma espécie de utilização de um grande palco onde os indivíduos podem desfilar o seu narcisismo e obter seu reconhecimento, porém onde também vivem a busca do impossível: obter a reciprocidade do amor pela empresa e a sua consideração aos sentimentos humanos. A autora desabafa:

Muito se tem falado sobre autoestima nos últimos tempos e ela tem sido colocada fora do indivíduo, em lugares como o brilho do nome da empresa em que trabalha, o nível de importância dos relacionamentos privilegiados no ambiente de trabalho, as posses emprestadas pelo sucesso profissional. Pouco se tem dito sobre o fato de que um indivíduo não é o mesmo que a sua imagem ou a ideia que os outros têm dele. Dar a uma organização, por especial que ela seja, o direito de definir quem se é, representa um perigo próximo a dançar de olhos fechados à beira de um abismo, e como os ventos das reestruturações estão sempre soprando, o risco é de morte, portanto, é preciso o indivíduo ter claro quem é o verdadeiro objeto de seu amor. (Freitas, 2007, pp. 95-96).

De acordo com Srour (2005), basta adentrar qualquer organização para se sentir perplexo por uma presença amórfica. Percebe-se no ar um mistério, tal qual uma esfinge que, através da sua aparência assustadora, sugere a famosa frase: 'decifra-me ou te devoro'. 
Smircich (1983) fez uma ampla revisão da literatura e de pesquisas empíricas e construiu uma argumentação, na qual faz cinco interseções entre as teorias de cultura (da Antropologia) e de organização (da Teoria Organizacional), a fim de sustentar sua tese de que as diferenças de abordagem para o relacionamento entre estas duas concepções decorrem de diferenças nas suposições básicas que os pesquisadores fazem, tanto sobre a organização quanto sobre a cultura. Segundo a autora, cada uma das cinco interseções (temas) representa uma forma viável e promissora de investigação. Se consideradas juntas, estas temáticas sugerem um variado e rico aperfeiçoamento para o conceito de cultura no estudo de organizações.

Smircich (1983) destaca que organizações complexas como configurações culturais têm permitido a estudiosos e pesquisadores fornecer uma educação universal tanto para desenvolver soluções para graves doenças quanto, até, para explorar o espaço sideral. Em contraste, há organizações complexas que contribuem para a destruição do meio ambiente e para a possibilidade de uma aniquilação nuclear.

Complementa a autora que uma estrutura cultural para análise organizacional estimula estudiosos, pesquisadores e gestores a perceber a relevância do que se está desenvolvendo, tanto para os que estudam quanto para aqueles que gerenciam. Portanto, não se trata de celebrar a organização como um valor, mas sim questionar os fins a que ela se destina. $O$ fato de ser e pertencer a uma cultura de estudiosos, pesquisadores e gestores dificulta esta própria classe da mesma forma, tanto para viver nesse contexto cultural quanto para questioná-lo. É difícil envolver-se em uma pesquisa contextual sobre administração reflexiva, com a exigência de exame e crítica de seus pressupostos e valores; mas é o que a estrutura cultural para a gestão e pesquisa está estimulando, para que isto se concretize.

Na Tabela 7 há uma relação com doze exemplos de conceitos, dentre inúmeros existentes sobre cultura organizacional, de estudiosos que pesquisaram o tema. Nesta tabela percebe-se a recorrência de padrões nos conceitos apresentados, dos quais é possível inferir que a cultura organizacional parece ser um código de normas seguido por um grupo, não necessariamente homogêneo, em termos de capacidades e interesses. Embora não esteja expressamente descrito, é importante frisar o caráter dinâmico de renovação da cultura, decorrente de mudanças no entorno ambiental externo e interno dos grupos e subgrupos. O conceito de 
cultura vem sendo utilizado por todos aqueles, sejam acadêmicos ou não, que se interessam pelo estudo da evolução e comportamento da cultura organizacional $(\mathrm{CO})$ ao longo do tempo.

\section{Tabela 7}

\section{Conceitos sobre cultura organizacional}

\begin{tabular}{|c|c|}
\hline Descrição & Referências \\
\hline $\begin{array}{l}\text { "[...] é um sistema de significados pública e coletivamente aceitos } \\
\text { operacionalmente no âmbito de determinado grupo, em um dado momento. } \\
\text { Este sistema de expressões, formas, categorias e imagens fornece às pessoas } \\
\text { do grupo uma interpretação de sua própria situação". }\end{array}$ & Pettigrew $(1979$, p.574) \\
\hline $\begin{array}{l}\text { "[...] conjunto de significados que se desenvolvem e dão a um grupo seu } \\
\text { próprio [...] caráter distintivo, que é expresso em padrões de crenças } \\
\text { (ideologias), atividades (normas e rituais), línguas ou outras formas } \\
\text { simbólicas através do qual os membros de uma organização criam e mantêm } \\
\text { seu ponto de vista do mundo e a imagem de si mesmo no mundo. O } \\
\text { desenvolvimento de uma visão do mundo com seus entendimentos } \\
\text { compartilhados de uma identidade, sentido e direção [...] são produtos da } \\
\text { história única, interações pessoais e as circunstâncias do grupo". }\end{array}$ & Smircich $(1983$, p.56) \\
\hline $\begin{array}{l}\text { "[...] é um padrão de crenças e valores compartilhados que dão aos membros } \\
\text { de uma instituição significados e os proveem com regras de comportamentos } \\
\text { em suas organizações". }\end{array}$ & Davis $(1984$, p. 1) \\
\hline $\begin{array}{l}\text { "[...] é uma série de entendimentos e significados compartilhados por um } \\
\text { grupo de pessoas. Os significados são tácitos em grande medida entre os } \\
\text { membros, são claramente relevantes para algum grupo em particular, e } \\
\text { distintivos para o grupo". }\end{array}$ & Louis $(1985$, p. 74$)$ \\
\hline $\begin{array}{l}\text { Pode ser definida como "[...] um conjunto complexo de valores, crenças, } \\
\text { suposições e símbolos que definem a forma pela qual uma empresa conduz } \\
\text { seus negócios". }\end{array}$ & Barney (1986, p.657) \\
\hline $\begin{array}{l}\text { "[...] consiste em um conjunto de símbolos, cerimônias e mitos que } \\
\text { comunicam os valores e crenças subjacentes dessa organização a seus } \\
\text { empregados. Estes rituais concretizam aquilo que, do contrário, seriam ideias } \\
\text { esparsas e abstratas, dando-lhes vida de modo a que tenham significado e } \\
\text { impacto para um novo empregado". }\end{array}$ & Ouchi (1988, p. 43) \\
\hline $\begin{array}{l}\text { "[...] é uma força social que controla padrões de comportamento } \\
\text { organizacional modelando as cognições e percepções de significados e } \\
\text { realidades que os membros têm, fornecendo energia efetiva para a } \\
\text { mobilização e identificando quem pertence e quem não pertence". }\end{array}$ & Ott (1989, p. 69) \\
\hline $\begin{array}{l}\text { "[...] refere-se ao padrão de crenças, valores e meios aprendidos de lidar com } \\
\text { a experiência que tiveram durante o curso da história de uma organização, } \\
\text { que tende a ser manifestada em seus arranjos materiais e no comportamento } \\
\text { de seus membros". }\end{array}$ & Brown $(1998$, p. 7$)$ \\
\hline $\begin{array}{l}\text { "[...] se refere aos valores, suposições subjacentes, expectativas e definições } \\
\text { presentes em uma organização. Ela representa 'como as coisas são feitas por } \\
\text { aqui'. Isto reflete a ideologia dominante que o grupo carrega dentro de si”. }\end{array}$ & Cameron e Quinn (1999, p. 10) \\
\hline $\begin{array}{l}\text { "É holística, referindo-se ao todo organizacional; é determinada } \\
\text { historicamente porque reflete a história da mesma; se relaciona com estudos } \\
\text { antropológicos (rituais e símbolos); é construída socialmente porque é criada } \\
\text { e mantida pelo grupo que forma a organização; e é difícil de mudar, embora } \\
\text { não haja acordo sobre o grau de dificuldade". }\end{array}$ & Hofstede (2003, p. 210) \\
\hline $\begin{array}{l}\text { "[...] é o conjunto de artefatos, valores e pressupostos que emergem das } \\
\text { interações dos membros organizacionais". }\end{array}$ & Keyton (2005, p. 28) \\
\hline $\begin{array}{l}\text { Pode ser definida como "[...] um padrão de suposições básicas } \\
\text { compartilhadas, que foi aprendido por um grupo à medida que solucionava } \\
\text { seus problemas de adaptação externa e de integração interna". }\end{array}$ & Schein $(2009$, p. 16$)$ \\
\hline
\end{tabular}


Nota-se que há uma área de delimitação de conceitos que se caracteriza por grande concisão, é o caso de Keyton (2005) e depois Davis (1984), passando por outros que se situam em uma área intermediária, culminando com o conceito mais extenso de Smircich (1983). Esta autora consegue trazer e representar uma série de características importantes da $\mathrm{CO}$, abrangendo aspectos organizacionais, linguísticos e socioantropológicos.

Apesar da ampla revisão de literatura de Smircich (1983), esta autora não sistematizou uma teoria sobre cultura organizacional. Dentre as abordagens sobre CO que mais se destacaram no mundo acadêmico, foram escolhidas duas, devido ao grande número de citações e de aderência a este trabalho. A primeira é feita por Schein (2009), com a complementação feita por Denison, Hooijberg, Lane e Lief (2012) que se basearam na abordagem de Schein, e desenvolveram uma teoria derivada. A segunda abordagem é feita por Hofstede (2003), que analisa CO e culturas nacionais e traz aspectos importantes sobre a cultura dos sistemas de contabilidade, contemplada na seção que trata da sua teoria.

Contudo, muitos trabalhos nacionais e internacionais têm sido elaborados, usando abordagens alternativas de outros pesquisadores como a que trata de tipologias culturais de Cameron e Quinn (1999), e as de Pettigrew (1979) e de Brown (1998). O próprio Schein (2009) dedica um capítulo do seu livro às tipologias culturais, e cita, dentre os autores que ele pesquisou, o trabalho de Cameron e Quinn e do próprio Hofstede. 


\subsubsection{Cultura Organizacional segundo Edgar H. Schein (2009)}

Schein (1984) apresentou, em artigo clássico, a sua teoria sobre cultura organizacional, que visava compreender as forças dinâmicas evolutivas que regem a forma como esta cultura evolui e se altera. Em suas palavras: “[...] a minha abordagem nesta tarefa será a de produzir formalmente uma definição do que eu acredito que seja a cultura organizacional, e ainda elaborar cada um dos elementos da definição para deixar claro como ela funciona" (p. 3).

Schein (1984, p. 14) conclui, afirmando:

Se tais estudos mostram que esse modelo de cultura é útil, uma das principais implicações será que nossas teorias de mudanças organizacionais terão que dar muito mais atenção para as oportunidades e as ameaças que a cultura organizacional proporciona. Claramente, se a cultura é tão poderosa como defendo neste artigo, será mais fácil fazer as mudanças que são condizentes com as atuais suposições, e será muito mais difícil fazer as mudanças que não são. Em suma, o conhecimento de cultura organizacional se tornará, então, parte integrante do processo de gestão em si.

$\mathrm{Na}$ sua abordagem mais recente, Schein (2009) destaca que o aprendizado do grupo organizacional ocorre à medida que estes buscam soluções para os seus problemas de adaptação externa e de integração interna. Apesar de destacar estas dimensões, ele enfatiza a liderança como criadora e mantenedora da cultura e como o elemento fundamental que, ao longo do tempo, irá promover a sua adaptação e até o seu soerguimento, na hipótese de enfraquecimento desta, e que essas lideranças se sucedem com o tempo.

O que o autor denomina 'padrão de suposições básicas' tem funcionado bem o suficiente para ser aceito como válido. Por essa razão, este padrão pode ser ensinado e disseminado às novas pessoas que passam a fazer parte da organização, como um modelo concreto de pensar e perceber-se em relação a esses problemas. Ainda segundo Schein (2009), a cultura é um fenômeno dinâmico que envolve todos em todas as horas, sendo constantemente exercida e criada pelas interações dos indivíduos, e moldada por uma postura de liderança e um conjunto de regras e normas que orientam e restringem o comportamento.

Schein (2009) relembra que a cultura é um conceito abstrato e de história longa e complexa, usada pelos antropólogos para referir-se aos costumes e rituais que as sociedades 
criaram e desenvolveram ao longo de sua história. $\mathrm{O}$ autor enfatiza que na origem da cultura sempre esteve presente a figura da liderança. Assim, ao longo do tempo, havendo mudanças no ambiente externo que possam impactar e enfraquecer a cultura, novas lideranças surgem para adaptá-la, visando à sobrevivência e à perpetuação. O autor também afirma:

Para um conceito abstrato ser útil ao nosso pensamento, ele deve ser observável, além de aumentar nosso entendimento sobre um conjunto de eventos que são, contrariamente, misteriosos ou não bem entendidos. Desse ponto de vista, meu argumento é que devemos evitar os modelos superficiais de cultura e construir modelos antropologicamente mais profundos e complexos. A cultura como conceito será mais útil se ajudar-nos a entender melhor os aspectos ocultos e complexos da vida de grupos, organizações e ocupações profissionais, pois não podemos obter esse entendimento se usarmos definições superficiais. (p. 8).

$\mathrm{O}$ autor distingue três níveis essenciais que envolvem os componentes da cultura: artefatos; crenças e valores expostos; e suposições ou pressupostos básicos.

A essência da cultura de um grupo é o seu padrão de suposições básicas, compartilhadas, internalizadas e assumidas como verdadeiras. Apesar disso, a cultura poderá se manifestar no nível dos artefatos observáveis e das crenças e valores assumidos e compartilhados (Schein, 2009). A Figura 3 apresenta as camadas ou níveis de cultura segundo o autor.
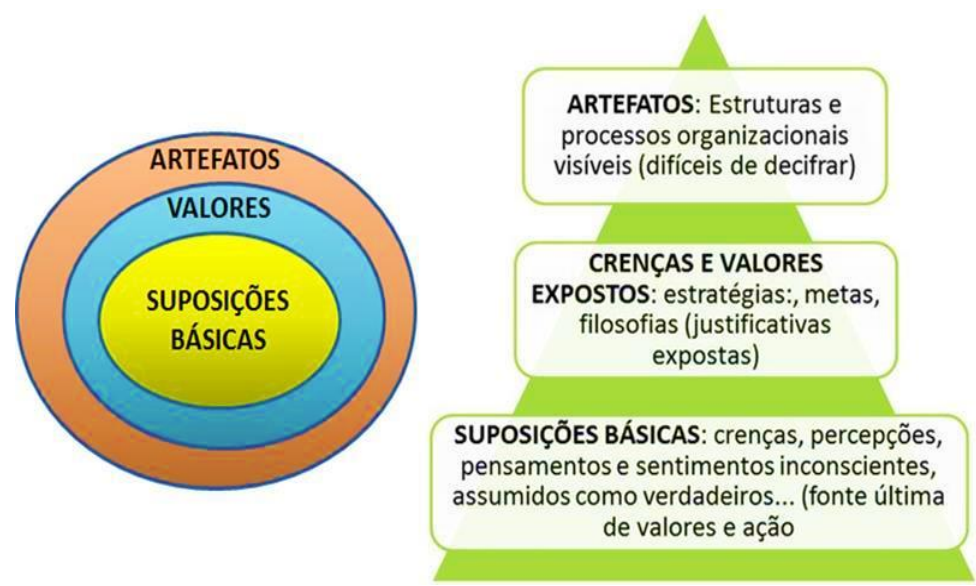

Figura 3. Camadas ou níveis de cultura de Schein.

Fonte: Adaptado de Schein, E. H. (2009). Cultura organizacional e liderança (p. 24). São Paulo: Atlas. 
Na Figura 3 podem ser vistos, à esquerda, os níveis de cultura organizacional na forma de 'camadas de cebola', onde a camada externa representa a parte mais visível - os artefatos -, porém difíceis de ser decifrados. Um pouco mais internamente encontra-se a camada das crenças e valores expostos, e no núcleo estão as suposições básicas compartilhadas. À direita, com maior detalhamento, encontram-se esses mesmos níveis, porém representados em forma piramidal, cuja base da pirâmide contempla as suposições básicas.

$\mathrm{O}$ autor esclarece que os artefatos abrangem os produtos e serviços visíveis do grupo, tais como a arquitetura do ambiente físico, a linguagem usada pelos grupos e subgrupos, suas tecnologias e técnicas, suas criações artísticas, seus processos organizacionais, os estilos do vestuário, as formas de comunicação entre os membros dos grupos, as manifestações emocionais, os mitos, heróis, a história e lendas contadas sobre a organização e as listas explícitas de valores, rituais e cerimônias possíveis de serem observadas, entre outros.

O nível das crenças e valores situa-se em um plano consciente e tem a função normativa do comportamento dos membros em situações decisivas. À medida que estas crenças e valores vão sendo empiricamente testadas e reforçadas na solução dos problemas do grupo, elas são transformadas em suposições, servindo como ideologia ou filosofia organizacional.

O nível de suposições ou pressupostos básicos refere-se às bases fundamentais dos sistemas de significados, e representa a verdadeira essência da cultura de grupo. Elas são como "mecanismos de defesa cognitivos e psicológicos que permitem ao grupo continuar a funcionar" (Schein, 2009, p. 30). Assim, constituem as soluções encontradas pelos grupos para resolver determinados problemas, tornando-se indiscutíveis e passadas (de forma inconsciente) para os novos membros da organização.

Schein (2009) defende com veemência a natureza qualitativa da pesquisa sobre cultura e mostra a metodologia que desenvolveu para diagnosticar a cultura organizacional com o objetivo de alterá-la de acordo com os planos estabelecidos pela liderança maior. Esta metodologia, que ele chama de pesquisa clínica, está descrita com detalhes mais adiante na Tabela 9. 
Contudo, uma limitação do modelo de abordagem deste autor é o seu foco restrito ao ambiente interno da organização, ou seja, não contempla detalhes do seu ambiente externo, tais como concorrência, referenciais de excelência, entre outros; mas ele assegura que o modelo mais relevante de avaliação da cultura é aquele desenvolvido pela sociologia e a dinâmica de grupo, baseado na distinção fundamental entre os problemas de qualquer grupo ligados a “[...] (1) sobrevivência e adaptação a seu ambiente externo e (2) integração de seus processos internos para assegurar a capacidade de continuar a sobreviver e se adaptar" (p.81).

Schein $(2007$, p. 46) apresenta as etapas de adaptabilidade externa e integração interna em tópicos que ele denomina questões, e também complementa com 'certezas profundas', que estariam implícitas nas suposições básicas. Em obra recente (Schein, 2009), o autor atualiza esses elementos da cultura organizacional, vistos na Tabela 8.

Tabela 8

Dimensões e Questões da Cultura Organizacional segundo Schein (2009)

\begin{tabular}{|c|c|}
\hline DIMENSÕES & QUESTÕES \\
\hline \multirow{5}{*}{$\begin{array}{l}\text { Adaptação externa e } \\
\text { de sobrevivência: }\end{array}$} & $\begin{array}{l}\text { Missão e estratégia: obter entendimento compartilhado da missão essencial, da tarefa } \\
\text { principal e das funções manifestas. }\end{array}$ \\
\hline & Metas: desenvolver consenso sobre elas, derivadas da missão essencial. \\
\hline & $\begin{array}{l}\text { Meios: desenvolver consenso sobre o que utilizar para atingir as metas, como estrutura } \\
\text { da organização, divisão do trabalho, remuneração e autoridade. }\end{array}$ \\
\hline & $\begin{array}{l}\text { Mensuração: desenvolver critérios (e sistemas de informação e controle) a serem } \\
\text { usados para mensurar quão bem o grupo trabalha para atingir suas metas. Essa etapa } \\
\text { envolve a coleta de informações oportunas e úteis para interpretação, controle e } \\
\text { correção de rumo. }\end{array}$ \\
\hline & $\begin{array}{l}\text { Correção: Desenvolver consenso sobre o tratamento apropriado ou as estratégias } \\
\text { corretivas a serem usadas, caso as metas não estejam sendo atingidas. }\end{array}$ \\
\hline \multirow{5}{*}{ Integração interna: } & $\begin{array}{l}\text { Criar linguagem e categorias conceituais comuns: torna-se impossível a formação de } \\
\text { um grupo se seus membros não conseguirem se comunicar, interagir e se entender. }\end{array}$ \\
\hline & $\begin{array}{l}\text { Definir fronteiras do grupo e critérios de inclusão e exclusão: o grupo deve ter } \\
\text { capacidade de se definir: quem faz ou não faz parte; e critérios de filiação. }\end{array}$ \\
\hline & $\begin{array}{l}\text { Desenvolver normas de intimidade, amizade e amor: qualquer grupo deve determinar } \\
\text { as regras do jogo para os relacionamentos entre os membros, e como a abertura e a } \\
\text { intimidade devem ser tratadas no contexto da gestão das tarefas da organização. O } \\
\text { consenso nesta área é fundamental para as questões afetivas. }\end{array}$ \\
\hline & $\begin{array}{l}\text { Definir e alocar recompensas e punições: qualquer grupo deve saber o que são } \\
\text { recompensa e punição, e as razões pelas quais se consegue uma ou outra. }\end{array}$ \\
\hline & $\begin{array}{l}\text { Explicar o inexplicável (ideologia e religião): qualquer grupo enfrenta eventos } \\
\text { inexplicáveis cientificamente (religião), que devem receber significado para que se } \\
\text { possa reagir a eles e evitar a ansiedade de lidar com o inexplicável e gerenciar o } \\
\text { incontrolável. }\end{array}$ \\
\hline
\end{tabular}


Continuação da Tabela 8

\begin{tabular}{|c|c|}
\hline DIMENSÕES & QUESTÕES \\
\hline \multirow{6}{*}{$\begin{array}{l}\text { Certezas profundas } \\
\text { contributivas na } \\
\text { formação das } \\
\text { suposições básicas } \\
\text { compartilhadas }\end{array}$} & $\begin{array}{l}\text { Natureza da Realidade e da Verdade: suposições compartilhadas que definem o que é } \\
\text { real ou não; o que é fato no âmbito natural e no âmbito da sociedade; como a verdade é } \\
\text { finalmente determinada e se ela é revelada ou descoberta. }\end{array}$ \\
\hline & $\begin{array}{l}\text { Natureza do tempo: suposições comungadas que explicitam o conceito básico do } \\
\text { tempo no grupo; como esse tempo é medido; quantos tipos de tempo existem e a sua } \\
\text { relevância na cultura organizacional. }\end{array}$ \\
\hline & $\begin{array}{l}\text { Natureza do espaço: suposições comungadas sobre o espaço e sua repartição; seu } \\
\text { entendimento simbólico em torno do indivíduo; e seu papel na explicitação dos aspectos } \\
\text { dos relacionamentos (nível de intimidade e tipos de privacidade). }\end{array}$ \\
\hline & $\begin{array}{l}\text { Natureza da natureza humana: suposições compartilhadas que explicitam o } \\
\text { entendimento do que é ser humano e quais de seus atributos são considerados } \\
\text { intrínsecos ou conclusivos. Esta natureza é boa, má ou neutra? Os seres humanos } \\
\text { possuem potencial para o perfeccionismo ou não? }\end{array}$ \\
\hline & $\begin{array}{l}\text { Natureza da atividade humana: suposições comungadas que explicitam a coisa certa } \\
\text { para os seres humanos fazerem em relação ao seu ambiente, baseado na suposição } \\
\text { anterior. No direcionamento básico para a vida de alguém, qual o nível apropriado de } \\
\text { atividade ou passividade? No âmbito organizacional, qual o relacionamento da } \\
\text { organização com o seu ambiente? }\end{array}$ \\
\hline & $\begin{array}{l}\text { Natureza dos relacionamentos humanos: suposições compartidas que buscam } \\
\text { explicitar qual é, afinal, a forma correta de as pessoas se relacionarem e distribuírem } \\
\text { poder e amor. Há cooperação ou competição, individualismo, e cooperativismo em } \\
\text { grupo ou comunal? }\end{array}$ \\
\hline
\end{tabular}

Nota. Fonte: Adaptado de Schein (2009). Cultura organizacional e liderança (pp. 82, 104, 128). São Paulo: Atlas

Quanto aos itens relacionados nas duas primeiras dimensões, eles parecem mais compreensíveis e objetivos, mas a terceira dimensão traz elementos novos. Segundo Schein (2009), ser humano não é somente uma propriedade física, mas uma construção cultural ao longo da história. As suposições sobre a natureza humana são: a) os seres humanos são atores sociais e econômicos; b) os seres humanos são animais sociais com necessidades primordialmente sociais; c) os seres humanos são vistos como solucionadores de problemas e com capacidade de autorrealização, empreendedorismo e aptos a superar desafios; d) os seres humanos também podem ser vistos como seres complexos e maleáveis. Sobre a existência de cultura nas profissões, o autor comenta:

Se uma profíssão envolve intenso período de educação e aprendizagem, haverá certamente uma aprendizagem compartilhada de atitudes, normas e valores que por fim se tornarão suposições assumidas como verdadeiras pelos membros dessas profissões. Assumiu-se que as crenças e valores aprendidos durante esse tempo permaneceriam estáveis como suposições, muito embora uma pessoa possa nem sempre pertencer a um grupo de colegas da mesma profissão. Mas o reforço dessas suposições ocorre em reuniões profissionais e programas de educação continuada e em virtude do fato de que a prática da profissão frequentemente exige trabalho em equipe entre os vários membros que se reforçam mutuamente. Uma razão porque muitas profissões confiam fortemente na avaliação pelo grupo de colegas é que esse processo preserva e protege a cultura da profissão. (Schein, 2009, p.19). 
Quanto à cultura no âmbito docente, percebem-se, por exemplo, certas iniciativas por parte de IES que promovem eventos fechados aos professores, tais como 'semana pedagógica', 'repensando a educação', entre outros. Estas atitudes podem ser vistas como uma tentativa para melhorar e/ou renovar a cultura organizacional dentro do ambiente acadêmico.

Em outro instante, Schein (2009, p. 9) comenta: “[...] como professores, encontramos, às vezes, fenômenos misteriosos em que classes diferentes comportam-se de modo totalmente diferente entre si, muito embora nosso material e estilo de treinamento permaneçam os mesmos". O autor parece querer mostrar o confronto de culturas distintas, ou ainda as dificuldades de um processo de conscientização do fenômeno cultural em ação.

Com o propósito de mostrar a delimitação do constructo de cultura organizacional sob a sua ótica, Schein (2009) elaborou uma síntese de categorias com seus significados:

a) Regularidades comportamentais observadas quando da interação entre as pessoas: abrangem o tipo de linguagem que os membros do grupo empregam; os costumes e tradições que desenvolvem ao longo do tempo e os rituais que utilizam em ampla variedade de situações;

b) Normas do grupo: padrões e valores implícitos que surgem e evoluem em grupos de trabalho, como, por exemplo, a norma particular "um dia de trabalho justo por um pagamento diário justo", que passou a vigorar entre os empregados de determinada instituição financeira. (p. 12);

c) Valores expostos: princípios e valores articulados, divulgados publicamente, que o grupo afirma ao tentar atingir, tais como "qualidade do produto" ou "liderança em preço" (p. 12);

d) Filosofia formal: representa políticas amplas e princípios ideológicos para orientar as ações de um grupo em relação aos vários stakeholders de uma empresa;

e) Regras do jogo: são regras implícitas, informais, divulgadas em toda a organização; as dicas e macetes que um iniciante deve assimilar para ser aceito como membro do grupo;

f) Clima: percepção ou sentimento causado em um grupo pelo leiaute físico e a forma como os membros da entidade interagem; no caso das IES, com os colegas docentes, com os alunos, e demais pessoas que trabalham na organização; 
g) Habilidades natas: conhecimentos especiais demonstrados pelos membros de um grupo para a realização de certas atividades ou tarefas, ou seja, são habilidades para fazer determinadas coisas que passam de geração a geração, sem necessariamente estar formalmente escritas;

h) Hábitos de pensar, modelos mentais e paradigmas linguísticos: representam modelos cognitivos que são compartilhados e que servem para guiar as percepções, o pensamento e a linguagem utilizados pelos indivíduos de um grupo e passados aos novos membros, no começo do processo de socialização;

i) Significados compartilhados: são entendimentos potenciais que surgem, criados pelos componentes do grupo, à medida que interagem entre si;

j) Metáforas raízes ou símbolos de integração: são as formas como os grupos se desenvolvem, podendo ou não ser analisadas conscientemente; mas terminam por ser inseridas nas edificações, leiautes de escritórios e outros artefatos materiais do grupo. Segundo Schein (2009) “esse nível de cultura reflete a resposta emocional e estética dos membros à medida que é contrastado com a resposta cognitiva ou avaliativa" (p. 13);

k) Rituais e celebrações formais: são modos pelos quais um grupo celebra ou comemora eventos-chave que representam valores relevantes de seus componentes, como, por exemplo, promoção e conclusão de projetos, entre outros.

Schein (2009) comenta que, para se levantar e identificar as suposições básicas compartilhadas da cultura de uma organização, é importante avaliar em que medida essas suposições contribuem ou não para as mudanças que esta entidade está querendo fazer, e destacar a utilidade desta avaliação cultural ao cliente. O trabalho de avaliação poderá ser iniciado desde que seja baseado na verificação dos pressupostos relacionados a seguir.

a) Sendo a cultura um conjunto de suposições compartilhadas, a obtenção dos dados iniciais do grupo seria mais apropriada do que realizar entrevistas individuais;

b) É importante a criação de um instrumento para o entendimento das suposições culturais, uma vez que estas já são entendidas pelos membros da cultura;

c) É impraticável tentar estudar uma cultura completa, porque nem todas as suas partes são relevantes;

d) Apesar de os membros da organização (insiders) se mostrarem capazes de entender e explicitar as suposições tácitas compartilhadas, componentes da cultura, eles precisam 
de alguém (outsider) que saiba decifrar a cultura. Contudo, o pesquisador deve buscar atuar apenas como consultor e jamais operar como um expert em cultura organizacional;

e) Certas suposições culturais serão percebidas como necessárias à organização para atingir suas metas estratégicas e resolver seus problemas, enquanto outras surgirão como restrições ou óbices. Assim, é importante para os insiders ter um processo que lhes propicie qualificar as suposições culturais em ambas as categorias;

f) O processo de identificar e entender a cultura, frequentemente, mostra que práticas novas não apenas podem como devem decorrer da cultura existente;

g) Caso seja necessário promover mudanças na cultura, elas raramente envolverão toda a cultura; na maioria das vezes será necessário mudar uma ou duas suposições.

A abordagem teórica de Schein (2007), em síntese, avalia a cultura organizacional de uma entidade através das seguintes etapas:

1) definir o problema da organização;

2) rever o conceito de cultura;

3) identificar os artefatos;

4) identificar os valores da a organização;

5) comparar os valores com os artefatos (estas sugestões de categorias de artefatos seriam transformadas em questões, adaptando-as às peculiaridades do tipo de organização):

a) códigos na maneira de se vestir; b) nível de formalidade nos relacionamentos com superiores ou autoridades; c) horários de trabalho; d) reuniões (frequência, direcionamento e duração); e) atividades principais realizadas; f) como são tomadas as decisões; g) comunicações (como as pessoas sabem das coisas); h) eventos sociais; i) uniformes, jargões utilizados e símbolos de identidade; i) ritos e rituais; j) desacordos e conflitos (como se lida com eles); k) equilíbrio entre trabalho e família; 1) experiências anteriores; $\mathrm{m}$ ) tempo de trabalho na organização.

6) repetir o processo com outros grupos; e

7) avaliar as certezas compartilhadas.

Em abordagem mais recente, Schein (2009) desdobrou as etapas acima descritas de forma mais minuciosa, e a chamou de 'pesquisa clínica', que contém um programa de etapas. As descrições apresentadas na Tabela 9 revelam a essência teórica da sua pesquisa clínica, porém com algumas adaptações realizadas pelo autor para adequação às IES. 
Tabela 9

Etapas para avaliação da cultura organizacional

\section{Descrição das etapas}

i. Obter comprometimento da liderança: o líder maior da IES deve estar ciente dos objetivos da pesquisa, visto que decifrar as suposições culturais e avaliar sua relevância para algum propósito organizacional, geralmente, é considerado uma intervenção na vida da organização, e este apoio da liderança costuma propiciar e facilitar o acesso à coleta dos dados e a obtenção de resultados concretos;

ii. Selecionar grupos e/ou indivíduos para entrevistas: esta etapa é feita com os coordenadores do curso, desde que sejam docentes do mesmo, que escolherão os professores que queiram e possam participar, dando preferência aos mais antigos na IES. Deve ser entrevistado um número de docentes entre oito e dez por IES, para evitar vieses em uma interpretação posterior. Os gestores devem informar ao grupo o propósito geral das entrevistas, para que estes fiquem cientes e possam melhor acolher o pesquisador;

iii. Selecionar um local adequado às entrevistas: geralmente uma sala confortável e climatizada atende às necessidades, preferencialmente dentro da IES. É conveniente o uso de gravador na entrevista. Assim, devese buscar sensibilizar o entrevistado quanto a sua importância para a posterior transcrição das informações. Dessa forma, assegura-se que a pessoa a ser entrevistada sinta-se confortável com o uso deste acessório.

iv. Explicar o propósito da reunião ao grupo: a presença do gestor de curso, tanto quanto possível, reforça o objetivo do trabalho, visando encorajar a sinceridade das respostas. O pesquisador é apresentado como a pessoa que conduzirá o processo de levantamento das informações sobre a cultura organizacional;

V. Fazer breve explanação sobre como pensar a cultura: é importante que o pesquisador apresente os fundamentos do modelo dos níveis de cultura; isto assegura que todos do grupo entendam a distinção entre os três níveis, e que a cultura é formada por um conjunto de suposições baseado na história compartilhada do grupo;

vi. Identificar descrições dos artefatos: o pesquisador inicia o levantamento da cultura por meio de seus artefatos. A questão norteadora para se chegar a estes é: Que ações vocês realizam por aqui? Uma opção útil para começar é conhecer o docente que se uniu ao grupo mais recentemente, perguntando a ele o que sentiu ao entrar na IES e o que achou mais importante naquele momento. Anotar as respostas objetivamente;

vii. Identificar os valores assumidos: a questão a ser formulada é: Por que você realiza esta ação? As respostas fornecerão elementos para a elaboração de novas questões e/ou 'porquês'. Geralmente isto provoca declarações de valor, como por exemplo: prioriza-se resolver o problema do que falar com a autoridade formal; à medida que os valores ou as crenças são declarados, o pesquisador os anota para posterior consolidação em um segundo momento, quando compará-los com os valores e crenças de outros que já foram entrevistados.

iii. Identificar as suposições tácitas compartilhadas: o fator-chave de sucesso para chegar às suposições básicas é checar se os valores assumidos identificados realmente explicam todos os artefatos, ou se as coisas que foram explicadas ou descritas como "em andamento" continuam sem esclarecimento ou estão em conflito com algum dos valores articulados. Essa atividade se encerra quando o pesquisador identificou a maioria das áreas de suposições críticas e as pessoas passam a entender o que é uma suposição.

ix. Identificar apoios e obstáculos naturais: Esta atividade depende, parcialmente, de como e do que foi descoberto na etapa anterior. Caso o pesquisador não tenha chegado a uma conclusão satisfatória sobre as suposições básicas, há duas opções: 1) investir mais tempo em entrevistas adicionais, aperfeiçoando as suposições e identificando outras que possam ter sido omitidas; e 2) categorizá-las conforme apoiem ou atrapalhem a solução do problema que está sendo tratado. 
Continuação da Tabela 9

\section{Descrição das etapas}

x. Relatar suposições e fazer a análise conjunta: esta atividade visa obter algum consenso sobre a importância das suposições compartilhadas e suas derivações no que a organização tenciona fazer. Inicia-se com o relato individual da análise dos professores ao número máximo de membros do grupo. Caso haja alto grau de consenso, o pesquisador pode discorrer sobre as implicações desses resultados em possíveis processos de mudança. Podem ocorrer alguns conflitos que exigirão um feedback de todo o grupo, por exemplo: identificaram-se poucas suposições compartilhadas. Em cada caso, o pesquisador limita-se a fazer perguntas, buscar a persuasão através de esclarecimentos, testar percepções e descobrir outras formas de ajudar o grupo a obter um quadro, tão claro quanto possível, do conjunto de suposições que estão direcionando as percepções diárias, os sentimentos, os pensamentos e, por fim, o comportamento do grupo.

Nota. Fonte: Adaptado de Schein (2009). Cultura organizacional e liderança (pp. 318-324). São Paulo: Atlas

No desenvolvimento, pesquisa e atualização de seu trabalho, Schein (2009) elaborou uma análise comparativa na qual apresenta alternativas de pesquisa da cultura organizacional sob dois níveis de envolvimento: a) do pesquisador (quantitativo e qualitativo); e b) no assunto (mínimo; médio; e máximo). Nessa comparação ele conclui que a 'pesquisa clínica’ possui o maior e melhor resultado nas duas modalidades, conforme apresentado na Tabela 10.

Tabela 10

\section{Categorias de pesquisa nas organizações}

\begin{tabular}{|c|c|c|}
\hline \multirow{2}{*}{$\begin{array}{c}\text { Nível de } \\
\text { envolvimento } \\
\text { no assunto } \\
\end{array}$} & \multicolumn{2}{|c|}{ Nível de envolvimento do Pesquisador } \\
\hline & Baixo a médio - quantitativo & Alto - qualitativo \\
\hline Mínimo & $\begin{array}{l}\text { Dados demográficos: mensuração das } \\
\text { "variáveis distais" a }\end{array}$ & $\begin{array}{l}\text { Dados etnográficos: observação participante; } \\
\text { análise de conteúdo de histórias, mitos, } \\
\text { cerimônias, símbolos e outros artefatos }\end{array}$ \\
\hline $\begin{array}{l}\text { Médio } \\
\text { (Parcial) }\end{array}$ & $\begin{array}{l}\text { Experimentação: questionários, } \\
\text { classificações, testes objetivos }\end{array}$ & $\begin{array}{l}\text { Testes projetivos; centos de avaliação; } \\
\text { entrevistas }\end{array}$ \\
\hline Máximo & $\begin{array}{l}\text { Ferramentas de qualidade total, como } \\
\text { controle estatístico de processo (CEP), } \\
\text { pesquisa-ação }\end{array}$ & $\begin{array}{l}\text { Pesquisa-clínica; desenvolvimento } \\
\text { organizacional }\end{array}$ \\
\hline
\end{tabular}

Nota. Fonte: Adaptado de Schein (2009). Cultura organizacional e liderança (p. 191). São Paulo: Atlas

${ }^{\text {a }}$ Variáveis distantes em termos de significado ou de localização

Embora o autor indique seu modelo como o mais adequado para o nível de profundidade dos resultados a ser obtidos, ele também aponta que há amplas possibilidades de o pesquisador aguardar e observar o que ocorre no campo empírico, permitindo que este possa combinar alguns dos elementos do modelo clínico e do método etnográfico, com observaçãoparticipante. Schein (2009) afirma que uma solução para o etnógrafo obter acesso aos informantes é analisar cuidadosamente o que ele pode oferecer à organização "[...] e trabalhar 
na direção de um contrato psicológico em que a organização se beneficie de alguma forma [...]" (pg. 195), algo semelhante a tornar-se uma espécie de cliente.

\subsubsection{Cultura organizacional segundo Denison, Hooijberg, Lane, \& Lief (2012)}

Denison et al. (2012) desenvolveram a abordagem contida nesta seção com base em seus estudos de cultura organizacional e nas experiências vivenciadas ao longo de vinte anos em inúmeras organizações de culturas nacionais distintas. Os autores mencionam que a base da sua concepção está apoiada no modelo conceitual de Schein, mas fizeram adaptações e incorporaram mais duas dimensões para avaliar a cultura organizacional. Eles argumentam que toda organização humana "[...] cria uma cultura única e própria. [...] sua cultura sempre reflete a sabedoria coletiva que vem das lições que as pessoas aprendem à medida que se adaptam e sobrevivem juntas ao longo do tempo." (p. 1).

A mentalidade e a visão de mundo das pessoas modelam a forma como elas usam as lições do passado para imaginar e formular estratégias para o futuro (Denison et al., 2012). Estes autores criaram um modelo denominado 'Pesquisa de Cultura Organizacional', amplamente utilizado, para auxiliar as organizações a focalizar as questões que realmente demandam atenção e que vão além de um debate sobre a satisfação, o envolvimento e o moral dos seus colaboradores, para melhor compreender as ações que podem ser adotadas, visando a continuidade das organizações no futuro.

Denison et al. (2012) acrescentam que é fácil esquecer dos indivíduos que construíram originalmente uma organização, porque as estruturas criadas e desenvolvidas geralmente sobrevivem ao criador ou são adquiridas por outras organizações. Esta situação faz com que os criadores se sintam minimizados na sua importância, e não como visionários dos sistemas que criaram. Contudo, em longo prazo, uma das decisões mais importantes de uma liderança “[...] é criar um caráter e uma personalidade únicos para sua organização, que sejam adequados ao ambiente de negócios e a diferenciem da concorrência” (p. 2).

Estes autores afirmam ainda que a cultura de uma organização possui impacto sobre o seu desempenho, de, pelo menos, quatro formas: 1) criando e desenvolvendo o sentido de missão 
e direção em uma organização; 2) construindo e mantendo um alto nível de adaptabilidade e flexibilidade ao ambiente; 3) nutrindo o envolvimento e o engajamento dos seus colaboradores; 4) suprindo uma consistência que esteja fortemente enraizada em um conjunto de crenças e valores essenciais.

Assim, pelo modelo conceitual dos autores, pode-se perceber que além dos dois objetivos adotados de Schein (2009) - adaptabilidade externa e integração interna -, eles incorporaram a consistência e a missão. Acrescentam os autores que estes são os traços culturais que mais claramente afetam o desempenho da organização, e é por onde se deve começar a avaliação da cultura e a sua mensuração, para efeito de controle das mudanças a serem implantadas. $\mathrm{O}$ modelo conceitual de Denison et al. (2012) pode ser visto na Figura 4:

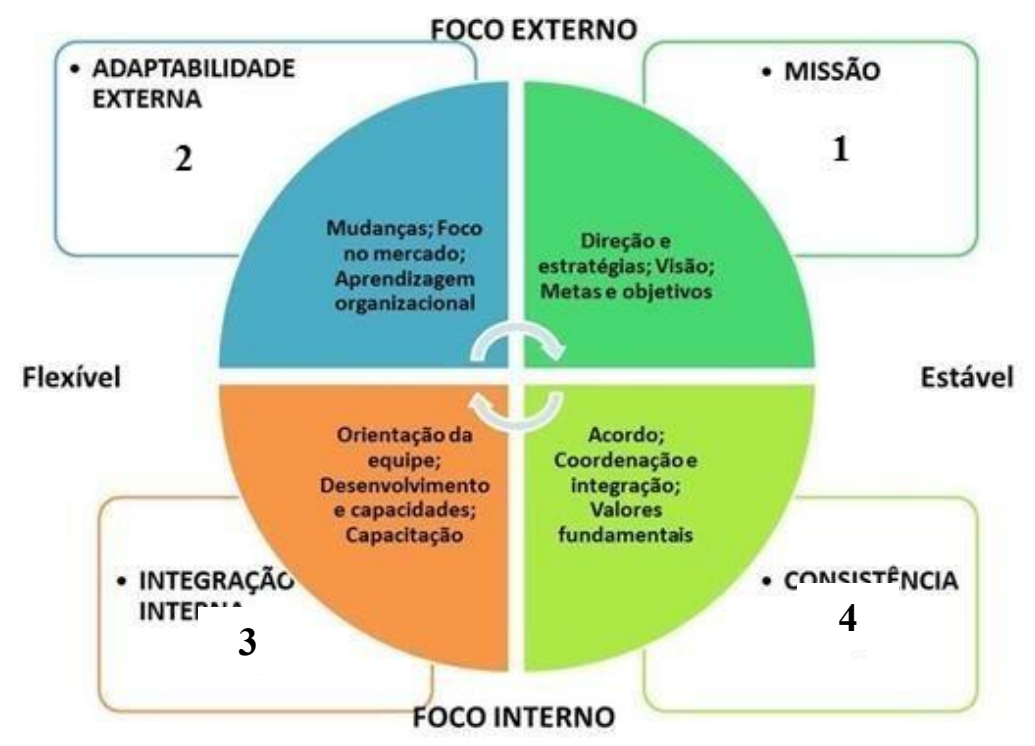

Figura 4. Modelo conceitual de Pesquisa de Cultura

Fonte: Adaptado de Denison et al. (2012). A força da cultura organizacional nas empresas globais: como conduzir mudanças de impacto e alinhar estratégia e cultura (p. 8). Rio de Janeiro: Elsevier

Podem ser observadas na figura as quatro dimensões do modelo, além dos sentidos na horizontal (Flexível e Estável) e na vertical (Foco externo e Foco interno). Embora estes sentidos pareçam ser antagônicos, os autores afirmam que o desejável é haver um equilíbrio entre eles. Na parte interna da figura estão as vertentes específicas de cada dimensão, de forma a gerar um indicador quantitativo para cada uma. 
Os referidos indicadores quantitativos propiciam o acompanhamento e controle da evolução das mudanças, em conformidade com o plano ou programa estabelecido pelo presidente ou líder maior da organização. No centro desta figura, embora não explícitas, encontram-se as crenças e suposições subjacentes que correspondem ao terceiro nível de cultura de Schein (2009).

O modelo representado na Figura 4 se concentra em um conjunto de contradições ou tensões dinâmicas que precisam ser gerenciadas. O equilíbrio entre a estabilidade e flexibilidade (eixo horizontal) e foco interno e o externo (eixo vertical) são as quatro tensões deste modelo e dimensões subjacentes básicas da sua estrutura (Denison et al., 2012). Complementam os autores que as tensões diagonais entre consistência interna e adaptabilidade externa versus missão e integração interna (ou envolvimento), tanto de baixo para cima como o inverso, são exemplos de algumas das demandas que as organizações enfrentam.

A dimensão 'missão', baseada nos autores, “[...] fornece propósito e significado ao definir um papel social convincente e um conjunto de metas para a organização" (p. 7). Acrescentam que os líderes possuem um papel fundamental na definição da missão, mas ressaltam que esta só pode ser atingida se, além de compreendida, for disseminada por todos, de cima a baixo. Os autores identificaram e se concentraram em três vertentes da missão: orientação estratégica e intenção; metas e objetivos; e visão (Denison et al., 2012).

A dimensão 'adaptabilidade externa' contempla o entendimento de que as entidades adaptáveis rapidamente convertem as demandas do ambiente organizacional, originadas como resposta às alterações no ambiente de negócios, em ações; mas, dizem os autores, organizações com propósito e direção rigorosamente definidos são as menos capazes de se adaptar e, portanto, mais difíceis de mudar. As três vertentes identificadas e nas quais os autores se concentraram foram: criação da mudança; foco no cliente; e aprendizagem organizacional.

Na dimensão 'integração interna' (ou envolvimento), está subentendido que as pessoas que compõem a organização estão fortemente comprometidas com suas atividades laborais, além de possuírem a consciência de que suas atribuições estão diretamente ligadas aos objetivos 
organizacionais. Denison et al. (2012) identificaram e se concentraram em três vertentes: capacitação; orientação da equipe; e desenvolvimento de capacidades.

Na dimensão 'consistência' está a compreensão de que a efetividade das organizações é influenciada fortemente pela coerência e a boa integração do seu ambiente interno. Estes aspectos comportamentais devem estar enraizados em um conjunto de valores fundamentais, e os colaboradores devem possuir habilidades para colocá-los em prática mediante um amplo acordo ou compromisso psicológico com as lideranças. Os autores identificaram e se concentraram em três vertentes: valores fundamentais; acordo; e coordenação e integração.

A abordagem de Denison et al. (2012) utiliza a chamada 'Pesquisa de Cultura Organizacional Denison', que utiliza técnicas quantitativas, com a aplicação de questionários, para a obtenção dos resultados, que são convertidos em indicadores para avaliação e mensuração do desenvolvimento das mudanças culturais planejadas pelo Chief Executive Officer (CEO) ou presidente de corporações lucrativas.

Na Tabela 11 são apresentadas as quatro dimensões identificadas pelos autores, desdobradas nas três vertentes respectivas, cada uma delas contendo cinco frases de onde são extraídos, via questionário, os indicadores quantitativos. Algumas dessas frases foram aproveitadas e transformadas, com adaptações, em questões que foram inseridas no roteiro semiestruturado, apresentado na seção 3.6 deste trabalho. Portanto, no roteiro original dos autores existem 5 frases $\times 3$ vertentes $\times 4$ dimensões $=60$, ou seja, sessenta frases resultam em sessenta indicadores, quinze para cada dimensão.

Tabela 11

Dimensões, vertentes e aspectos da Cultura Organizacional

\begin{tabular}{c|l}
\hline Dimensões / Vertentes & \multicolumn{1}{c}{ ASPECTOS ESPECÍFICOS DE CADA VERTENTE } \\
\hline \multirow{4}{*}{\begin{tabular}{c} 
1) $\begin{array}{c}\text { Direção Estratégica } \\
\text { e Intenção }\end{array}$ \\
\cline { 2 - 2 }
\end{tabular}} & Há um propósito e uma direção de longo prazo \\
\cline { 2 - 2 } & Nossa estratégia leva outras organizações a mudar a maneira como competem \\
\cline { 2 - 2 } & Há uma clara missão que dá sentido e direção ao nosso trabalho \\
\cline { 2 - 2 } & Nossa orientação estratégica é clara para mim \\
\hline \hline
\end{tabular}


Continuação da Tabela 11

\begin{tabular}{|c|c|}
\hline Dimensões / Vertentes & ASPECTOS ESPECÍFICOS DE CADA VERTENTE \\
\hline \multirow{5}{*}{ Metas e objetivos } & Há um consenso generalizado sobre as metas \\
\hline & Os líderes definem metas que são ambiciosas, porém realistas \\
\hline & A liderança é franca em relação aos objetivos que estão tentando alcançar \\
\hline & $\begin{array}{l}\text { Monitoramos continuamente nosso progresso em relação aos nossos objetivos } \\
\text { declarados }\end{array}$ \\
\hline & As pessoas entendem o que precisa ser feito por nós para ter sucesso no longo prazo \\
\hline \multirow{5}{*}{ Visão } & Temos uma visão compartilhada de como a organização será no futuro \\
\hline & Os líderes têm uma visão de longo prazo \\
\hline & Pensar em curto prazo muitas vezes compromete nossa visão de longo prazo \\
\hline & Nossa visão gera entusiasmo e motivação para nossos colaboradores \\
\hline & $\begin{array}{l}\text { Somos capazes de atender a demandas de curto prazo sem prejuízo da visão de longo } \\
\text { prazo }\end{array}$ \\
\hline \multirow{5}{*}{$\begin{array}{c}\text { 1) } \\
\frac{\text { ADAPTABILIDADE: }}{\text { Criação de mudanças }}\end{array}$} & A maneira como as coisas são feitas é muito flexível e fácil de mudar \\
\hline & Respondemos bem aos concorrentes e a outras alterações no ambiente de negócios \\
\hline & Novas e melhores maneiras de fazer o trabalho são continuamente adotadas \\
\hline & Tentativas de criar uma mudança geral encontram resistência \\
\hline & Diferentes partes da organização muitas vezes cooperam para criar mudança \\
\hline \multirow{5}{*}{ Foco no cliente } & Comentários de clientes e recomendações frequentemente levam a alterações \\
\hline & A entrada do cliente influencia diretamente nossas decisões \\
\hline & Todos os membros têm profunda compreensão do que o cliente quer e precisa \\
\hline & Os interesses do cliente muitas vezes são ignorados em nossas decisões \\
\hline & Incentivamos o contato direto de nossos funcionários com nossos clientes \\
\hline \multirow{5}{*}{$\begin{array}{l}\text { Aprendizagem } \\
\text { organizacional }\end{array}$} & Vemos o fracasso como uma oportunidade de aprendizado e melhoria \\
\hline & A inovação e a tomada de risco são estimuladas e recompensadas \\
\hline & Muitas coisas são ignoradas \\
\hline & A aprendizagem é um objetivo importante em nosso trabalho diário \\
\hline & Nós concordamos que "a mão direita sabe o que a esquerda está fazendo" \\
\hline \multirow{5}{*}{$\begin{array}{c}\text { 2) } \\
\frac{\text { ENVOLVIMENTO: }}{\text { Capacitação }}\end{array}$} & A maioria dos funcionários está altamente envolvida com seu trabalho \\
\hline & $\begin{array}{l}\text { As decisões são geralmente tomadas no nível em que a melhor informação está } \\
\text { disponível }\end{array}$ \\
\hline & $\begin{array}{l}\text { Amplo compartilhamento de informações para que todos possam obtê-las } \\
\text { seletivamente quando for preciso }\end{array}$ \\
\hline & Todos acreditam que pode haver impacto positivo \\
\hline & $\begin{array}{l}\text { O planejamento dos resultados é contínuo e envolve todos no processo, de alguma } \\
\text { maneira }\end{array}$ \\
\hline \multirow{5}{*}{ Orientação da equipe } & A cooperação entre diferentes partes da organização é incentivada \\
\hline & As pessoas trabalham como se fossem parte de uma equipe \\
\hline & $\begin{array}{l}\text { O trabalho em equipe é utilizado para 'pôr a mão na massa', em vez de manter a } \\
\text { hierarquia }\end{array}$ \\
\hline & Equipes são os principais blocos de construção \\
\hline & $\begin{array}{l}\text { Trabalho é organizado para que cada pessoa perceba a relação entre seu trabalho e os } \\
\text { objetivos da organização }\end{array}$ \\
\hline
\end{tabular}


Continuação (ainda) da Tabela 11

\begin{tabular}{|c|c|}
\hline Dimensões / Vertentes & ASPECTOS ESPECÍFICOS DE CADA VERTENTE \\
\hline \multirow{5}{*}{$\begin{array}{l}\text { Desenvolvimento } \\
\text { de capacidades }\end{array}$} & A autoridade é delegada para que as pessoas possam agir por conta própria \\
\hline & A capacidade das pessoas está em constante aperfeiçoamento \\
\hline & Há investimento contínuo nas habilidades dos empregados \\
\hline & As capacidades das pessoas são vistas como importante fonte de vantagem competitiva \\
\hline & $\begin{array}{l}\text { Problemas costumam surgir porque não temos as habilidades necessárias para fazer o } \\
\text { trabalho }\end{array}$ \\
\hline \multirow{5}{*}{$\begin{array}{c}\text { 1) } \\
\text { CONSISTÊNCIA: } \\
\text { Valores fundamentais }\end{array}$} & Os líderes e gestores 'praticam o que pregam' \\
\hline & Há um estilo de gestão característico e um conjunto distinto de práticas de gestão \\
\hline & $\begin{array}{l}\text { Existe um conjunto claro e consistente de valores que rege a forma como fazemos os } \\
\text { negócios }\end{array}$ \\
\hline & Ignorar valores fundamentais vai colocar você em problemas \\
\hline & $\begin{array}{l}\text { Há um código de ética que norteia nosso comportamento e nos diz o que é certo a partir } \\
\text { do que está errado }\end{array}$ \\
\hline \multirow{5}{*}{ Acordo } & $\begin{array}{l}\text { Quando ocorrem divergências, trabalhamos duro para chegar a soluções em que todos } \\
\text { ganham }\end{array}$ \\
\hline & Existe uma cultura 'forte' \\
\hline & É fácil chegar a um consenso, mesmo em questões difíceis \\
\hline & Muitas vezes, temos dificuldade de chegar a um acordo sobre questões fundamentais \\
\hline & Existe um acordo claro sobre a maneira correta e a errada de fazer as coisas \\
\hline \multirow{5}{*}{$\begin{array}{l}\text { Coordenação e } \\
\text { Integração }\end{array}$} & Nossa abordagem para fazer negócios é muito consistente e previsível \\
\hline & Pessoas de diferentes partes da organização compartilham uma perspectiva comum \\
\hline & É fácil coordenar os projetos entre todas as diferentes partes da organização \\
\hline & $\begin{array}{l}\text { Trabalhar com alguém de outra parte dessa organização é como trabalhar com alguém } \\
\text { de outra organização }\end{array}$ \\
\hline & Há um bom alinhamento de objetivos entre os níveis. \\
\hline
\end{tabular}

Nota. Fonte: Adaptado de Denison et al. (2012). A força da cultura organizacional nas empresas globais: como conduzir mudanças de impacto e alinhar estratégia e cultura (pp.179-182). Rio de Janeiro: Elsevier

\subsubsection{Cultura Organizacional segundo Hofstede (2003)}

Hofstede (2003) afirma que, na antropologia social, cultura é uma expressão que abrange todos os padrões de pensamento, sentimentos e comportamentos que se instalam na mente de uma pessoa, frutos de uma aprendizagem contínua adquirida desde a infância, época em que as pessoas são mais suscetíveis à aprendizagem, até a fase adulta e o resto da vida. Na fase adulta torna-se necessário às vezes desaprender, o que é mais difícil, para aprender e assimilar algo novo. Ele denomina este último processo de programação mental.

O autor busca, de forma complementar, esclarecer a ideia de aprendizado na infância e, depois, o processo de desaprender e aprender continuamente durante a vida. 
Cada um de nós transporta consigo padrões de pensamento, de sentimentos e de ação potencial, que são o resultado de uma aprendizagem contínua. Uma boa parte foi adquirida no decurso da infância, período de desenvolvimento onde somos mais suscetíveis à aprendizagem e assimilação. Quando certos padrões de pensamento, sentimentos e comportamentos se instalam na mente de cada um, torna-se necessário desaprender antes de aprender algo diferente, e desaprender é mais difícil que aprender pela primeira vez (Hofstede, 2003, p. 18).

Hosfstede (2003) dedica grande parte de seu trabalho a comparações entre as culturas organizacionais e as culturas nacionais. As peculiaridades distintas dos países influenciam significativamente as culturas organizacionais, principalmente em processos de fusões e aquisições. Nas culturas nacionais o autor identificou quatro dimensões: a distância hierárquica; o indivíduo e o coletivo; distinções de gênero; e o controle da incerteza.

Hofstede (2003) apresenta quatro camadas ou níveis como componentes da cultura organizacional nas quais ele apoia a sua abordagem, e que ele denomina manifestações de cultura, quais sejam: os símbolos; os heróis; os rituais; e os valores. A Figura 5 também está apresentada na forma de 'camadas de cebola':

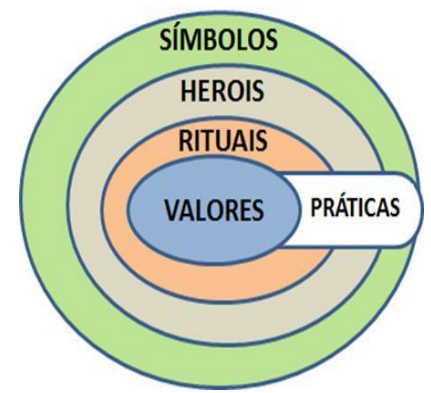

Figura 5. Camadas ou níveis de manifestação da cultura

Fonte: Adaptado de Hofstede, G. (2003). Culturas e organizações: compreender a nossa programação mental (p. 23). Lisboa: Edições Sílabo

O autor descreve que os símbolos são palavras, gestos ou objetos que carregam um significado particular, que é reconhecido só pelos que compartilham a cultura. Os termos e expressões de uma língua, as formas de vestuário, bem como os comportamentos entre os membros de um grupo, pertencem a esta categoria. Símbolos antigos desaparecem e são substituídos por outros em um processo contínuo. Em função dessa dinâmica, eles estão apresentados na camada externa na Figura 5. 
Os heróis podem ser pessoas existentes ou não, reais ou imaginárias, que têm características muito valorizadas numa determinada cultura e, por essa razão, servem como referenciais de comportamento. Podem até se tratar de figuras de fantasia ou de lendas como, por exemplo, o Batman ou Asterix, entre outros. Em nosso mundo dominado pela imagem, em todas as suas aplicações, a aparência exterior dos heróis tornou-se mais importante que no passado.

Os rituais são atividades grupais, tecnicamente supérfluas, que visam atingir alvos desejados, porém tidos como fundamentais em uma dada cultura. Na Figura 5 os símbolos, heróis e rituais encontram-se fundidos sob a denominação de práticas por serem visíveis ao observador externo, porém invisíveis quanto à sua compreensão cultural, ou seja, como elas são compreendidas e interpretadas pelos indivíduos partícipes da cultura (Hofstede, 2003).

O núcleo da cultura compreende os valores, cuja maioria é inconsciente, não perceptíveis do exterior pelo pesquisador. $\mathrm{O}$ autor define um valor como "[...] a tendência para se preferir certo estado de coisas em face de outro" (p. 23). Eles possuem um lado positivo e outro negativo, por exemplo: bom e mau; limpo e sujo; bonito e feio; normal e anormal, entre outros.

Hofstede (2003) afirma que os estudos de cultura organizacional (CO) podem ser divididos em duas categorias: os que são baseados em informações qualitativas, que ele chama de intangíveis; e os que se baseiam em dados quantitativos ou tangíveis. Complementa o autor que as avaliações de cultura baseadas em estudos que combinam técnicas qualitativas e quantitativas têm a vantagem da confiabilidade e "[...] estabilidade temporal do instrumento, permitindo, portanto, estudos longitudinais" (p. 214), sobretudo quando um dos objetivos principais é fazer análises comparativas e destacar os contrastes.

O autor acrescenta que a mudança de cultura em uma organização, naturalmente, para obter um desempenho melhor, necessita de persistência e atenção sistemáticas mantidas pela pessoa que exerce a liderança. Ainda com relação à mudança cultural, o autor destaca que quando se muda individualmente as pessoas, estas tendem a se adaptar ao novo ambiente 
cultural. Contudo, quando se mudam grupos de pessoas, estes tendem a carregar a cultura do grupo para onde for.

Portanto, Hofstede (2003) afirma que promover a mudança é uma responsabilidade da alta gestão, que exige simultaneamente poder e conhecimento. $\mathrm{O}$ autor elaborou um roteiro em que os pesquisadores podem se basear para adaptá-lo à realidade das organizações a serem avaliadas. Este roteiro, sintetizado e descrito na Tabela 12, foi ligeiramente adaptado devido às características desta pesquisa.

Tabela 12

Passos-chave e considerações sobre a cultura organizacional

\begin{tabular}{|c|c|}
\hline PASSOS & DESCRIÇÃO DOS PASSOS \\
\hline \multirow[t]{2}{*}{01} & Deve-se começar com um mapa cultural da organização \\
\hline & - $\quad$ Fazer um diagnóstico da cultura organizacional \\
\hline \multirow{8}{*}{02} & Exige escolhas estratégicas \\
\hline & - A cultura atual está adequada à estratégia? \\
\hline & - Se não, a estratégia pode ser adaptada? \\
\hline & - Se não, que mudança é necessária na cultura? \\
\hline & - Esta mudança é possível? A organização possui as pessoas adequadas? \\
\hline & - Os benefícios esperados compensam os investimentos? \\
\hline & - Qual é o tempo real necessário para que as mudanças possam ser percebidas? \\
\hline & - Subculturas diferentes podem exigir abordagens diferentes \\
\hline \multirow{4}{*}{03} & Criar uma rede de agentes de mudança na organização \\
\hline & - Identificar pessoas-chave nos níveis estratégico, tático e operacional \\
\hline & - Se as pessoas-chave começarem, outros seguirão? \\
\hline & - Em que medida os resistentes podem ser convertidos? \\
\hline \multirow{5}{*}{04} & Desenhar e promover as mudanças estruturais necessárias \\
\hline & - Abrir ou fechar departamentos ou projetos \\
\hline & - Fundir ou dividir departamentos, projetos ou atividades \\
\hline & - Mudar grupos ou apenas indivíduos? \\
\hline & - As atividades estão ajustadas aos talentos? \\
\hline \multirow{4}{*}{05} & Desenhar e promover as mudanças de processos necessários \\
\hline & - Estabelecer e/ou eliminar controles e indicadores para mensuração \\
\hline & - Estabelecer e/ou cortar canais de comunicação \\
\hline & - Substituir os controles na origem (input) por controles de resultados (output)? \\
\hline \multirow{5}{*}{06} & Rever as políticas de recursos humanos (RH) \\
\hline & - Reconsiderar critérios de promoção e de recompensas \\
\hline & - A gestão de RH está preparada para suas novas atividades? \\
\hline & - Elaborar e desenhar um rodízio de funções \\
\hline & - Formar e/ou capacitar apenas colaboradores motivados e criar esta motivação \\
\hline \multirow{3}{*}{07} & Acompanhar e controlar continuamente a evolução da cultura organizacional \\
\hline & - Perseverança e atenção focalizada \\
\hline & - Repetir periodicamente o diagnóstico de cultura \\
\hline
\end{tabular}

Nota. Fonte: Adaptado de Hofstede (2003). Culturas e organizações: compreender a nossa programação mental (p. 236). Lisboa: Edições Sílabo 
Neste roteiro, Hofstede (2003) prioriza a diagnose da cultura organizacional e as imediatas estratégias para promover as mudanças necessárias para o desenvolvimento da organização. Ao repetir, periodicamente, o diagnóstico da cultura organizacional, o autor parece incorporar esse instrumental ao processo de planejamento estratégico das organizações.

\subsubsection{Contabilidade como manifestação da cultura}

Hofstede (2003) destacou a importância de se estudar a contabilidade e os sistemas contabilísticos sob o ponto de vista cultural. Ele comenta que a sua "[...] tese de doutoramento abordou as consequências comportamentais da elaboração de orçamentos e, inconscientemente, suportou a hipótese da natureza ritual da contabilidade orçamental" (p. 184). É um aspecto curioso na obra do autor que, de certa forma, traz alguns elementos que, direta e/ou indiretamente, tangenciam o objeto deste trabalho, no que diz respeito à $\mathrm{CO}$ nas IES que mantêm cursos nessa área. É oportuno ressaltar que as informações apresentadas aqui têm como justificativa não só a pertinência do assunto ligado a este trabalho, como também as próprias declarações do autor, ou seja, se ele falou de sistemas contabilísticos é porque teve a oportunidade de estudá-los com mais profundidade para a elaboração de sua tese.

Menciona o autor que a contabilidade e seus sistemas de controle de gestão são manifestações da cultura e refletem suposições culturais fundamentais. Por exemplo, nos países que estão sob a égide da Common Law (Direito Consuetudinário), como os Estados Unidos e os países do Reino Unido, existe um campo de pesquisa chamado Contabilidade Comportamental, o qual, devido ao individualismo norte-americano, concentra-se mais no comportamento do indivíduo - e de pequenos grupos ligados a grandes organizações - do que no contexto cultural onde se pratica a contabilidade.

O autor acrescenta que é pouco provável que os contabilistas se convertam em heróis dentro das organizações, mas o seu desempenho é relevante na identificação e consagração desses heróis (diretor responsável), pois são os contadores que passam o atestado de 'bom ou mau comportamento', na medida em que as demonstrações contábeis recebem o certificado sem ressalvas das empresas de auditoria, indicando que elas representam com fidedignidade, em seus aspectos relevantes, a situação econômica, financeira e patrimonial das entidades. 
Afirma o autor que por trás dos símbolos, heróis e rituais da contabilidade existem os valores. Assim, quanto menos uma atividade for determinada por uma necessidade técnica, mais ela é orientada por valores e, consequentemente, sofre mais influência de distintas culturas. Nas palavras de Hofstede (2003, p.185), “[...] a contabilidade é um domínio no qual os imperativos técnicos são escassos: as convenções de origem histórica são mais importantes que as leis da natureza. É, assim, lógico que os sistemas contabilísticos e as formas de utilizálos variem de país para país".

O autor complementa que nos países com elevado controle de incerteza (Alemanha, França e Itália, entre outros), os sistemas contabilísticos não apenas são mais detalhados como também possuem maior fundamentação teórica, supostamente, decorrente de sólidos princípios econômicos gerais. Nesse primeiro grupo de países (Code $\operatorname{Law}^{9}$ ) as informações para os acionistas e para o físco são as mesmas. Já no segundo grupo de países (Common $\left.L a w^{10}\right)$ que têm como característica um baixo controle de incerteza (Estados Unidos, mundo anglo-saxônico e Holanda, entre outros), os sistemas são mais pragmáticos e a tendência para aceitar as tradições da contabilidade como existem sobrepõe-se às tendências para se basear em postulados gerais. Nesse segundo grupo as informações são distintas para cada usuário.

Conclui o autor que, devido a estes dois tipos de codificação, é provável que a profissão de contabilista ocupe uma posição inferior nas sociedades que ele denomina coletivistas (Code Law) e que o trabalho dos contabilistas é um ritual sem impacto prático sobre as decisões. Infere-se, a partir dessa observação do autor, que a profíssão do contabilista nos países sob o regime Common Law seja mais valorizada que a mesma profissão nos países sob o regime Code Law. Pelo menos, aqui no Brasil, em geral, essa inferência parece ser consistente.

Infere-se ainda, a partir da narrativa do autor, a difícil tarefa conduzida pelo International Accounting Standards Board (IASB) com o Financial Accounting Standards Board (FASB), de buscar a convergência e harmonização dos princípios e normas contábeis no âmbito internacional. Decorre desse contraste, talvez, a característica da cultura das IES que mantêm

\footnotetext{
${ }^{9}$ Direito de tradição romana ou direito codificado, entre os quais estão o Brasil, Itália, Alemanha e França

${ }^{10}$ Direito consuetudinário, construído ao longo do tempo a partir de costumes e tradições que é presente em países como do Reino Unido (Inglaterra, País de Gales etc.), Estados Unidos, Holanda etc.
} 
cursos de Contabilidade, em nível global, de possuir currículos e procedimentos distintos para o desenvolvimento e formação de seus profissionais em Contabilidade.

As corporações multinacionais e transnacionais têm necessidade de impor em todas as suas filiais as normas de contabilidade do seu país de origem para fins de consolidação, além das normas obrigatórias do país da filial. Atualmente, com as International Financial Reporting Standards ${ }^{11}$ (IFRS), há um caminho formal de adoção de normas internacionais já em muitos países, minimizando suas distinções. Contudo, na época em que Hofstede (2003) elaborou a sua ampla pesquisa na IBM, coletando dados e informações de todos os países onde a empresa encontrava-se sediada, ele constatou que os profissionais de contabilidade de diferentes países possuíam valores pessoais bastante distintos e esse aspecto cultural parece ter implicado na interpretação, por estes, das normas contábeis das filiais, fazendo com estas se afastassem das expectativas do país de origem da empresa.

Embora todo o livro do Hofstede (2003) trate do confronto entre a cultura organizacional e as culturas nacionais, ele conclui o seu capítulo, no qual trata da cultura dos sistemas de contabilidade, afirmando que incluiu esse tema na obra tendo em vista a oportunidade de têlos estudado de perto (p.186). Diz ainda que isso não significa que apenas a contabilidade e os contabilistas mereçam ser o único subsistema da organização a ser estudado sob o ponto de vista cultural. Os subsistemas “de gestão de recursos humanos, de informação, de marketing e de gestão financeira têm, também, os seus aspectos rituais e culturais” (p.186).

\subsection{Práticas docentes associadas à cultura organizacional acadêmica}

As práticas docentes estão associadas à cultura organizacional das IES, na medida em que os docentes representam, junto com a gestão do curso, os recursos, métodos e documentos, os principais componentes da cultura organizacional. Assim, as práticas docentes podem ser entendidas como os conhecimentos e técnicas que fazem parte da cultura organizacional no que diz respeito à operacionalidade do processo ensino-aprendizagem em sala de aula.

\footnotetext{
${ }^{11}$ Padrões Internacionais de Relatório Financeiro
} 
Para o exercício da prática, são fundamentais o desenvolvimento e a formação de saberes ou conhecimentos para operacionalizá-la. De acordo com Abbagnano (2007), o saber, verbo substantivado, é usado com dois significados principais:

1" Como conhecimento em geral, e neste caso designa: qualquer técnica considerada capaz de fornecer informações sobre um objeto; um conjunto de tais técnicas; ou o conjunto mais ou menos organizado de seus resultados. [...] 2" Como ciência, ou seja, como conhecimento cuja verdade é de certo modo garantida (p. 865).

A respeito do saber, Foucault (2010) comenta:

Um saber é aquilo de que podemos falar em uma prática discursiva que se encontra assim especificada: o domínio constituído pelos diferentes objetos que irão adquirir ou não um status científico [...]; o espaço em que o sujeito pode tomar posição para falar dos objetos de que se ocupa em seu discurso [...]; o campo de coordenação e de subordinação dos enunciados em que os conceitos aparecem, se definem, se aplicam e se transformam [...] as possibilidades de utilização e de apropriação oferecidas pelo discurso (p. 204).

Abbagnano (2007) afirma que o saber envolve o conhecimento em geral; e a ciência é um corpo sistematizado de conhecimentos verificáveis. Segundo Foucault (2010), percebe-se o saber, entre outros sentidos, como um campo de coordenação e de subordinação dos enunciados em que os conceitos aparecem; se definem; se aplicam e se transformam. Todavia, parece que os saberes, como conhecimento, arte e formas de comunicação, entre outros, estão implícitos na formação de uma cultura. Assim, a cultura contém, entre outros elementos, os saberes e, consequentemente, as práticas.

Tardif (2008) comenta que os saberes que servem de base para a profissão docente são temporais, ou seja, são adquiridos através do tempo e abrangem, em geral, os conhecimentos, competências e habilidades mobilizados diariamente nas salas de aula. No entanto, parece não haver um entendimento pacífico, entre os autores, nesta selva semântica a respeito dos termos saberes, práticas e competências. Pimenta e Anastasiou (2011) observam que, devido às permanentes pressões da dinâmica social e do mercado profissional nas universidades, as políticas dos órgãos reguladores e das próprias IES estão promovendo reconfigurações e um refinamento nos mecanismos de controle sobre as atividades dos docentes. 
Complementam as autoras que estas atividades, por sua vez, encontram-se amplamente preestabelecidas em inúmeras competências, cujo conceito está “[...] pelo menos tentando alterar, o de saberes e conhecimentos no campo da educação e o de qualificações (no campo do trabalho). [...] Essa substituição acarreta ônus para os professores, uma vez que os expropria de sua condição de sujeito do conhecimento". (p. 132). Competência é definida por Durand (1998) como um conjunto de conhecimentos, de habilidades e de atitudes que são interdependentes e necessários à realização de certas finalidades ou objetivos.

Assim, para efeito desta seção e de suas possíveis aplicações em outras partes deste trabalho, quando se estiver tratando de competências docentes, o seu significado abrange os saberes, habilidades, qualificações e atitudes, cuja ação se concretiza na prática docente.

Tardif (2008) afirma que os saberes estão presentes nas práticas docentes e que eles são originários de diversas fontes, entre elas, os saberes disciplinares, curriculares, profissionais e experienciais. Acrescenta o autor que os saberes experienciais representam para os docentes os fundamentos da prática e da competência profissional. Mais adiante, (p. 34) ele afirma que “[...] o valor social, cultural e epistemológico dos saberes reside em sua capacidade de renovação constante" e complementa que a formação baseada nos saberes estabelecidos é apenas uma introdução às atividades cognitivas consideradas como essenciais e adotadas pela comunidade científica.

Ratifica-se, pelo exposto, a necessidade de atualização contínua dos conteúdos curriculares, da formação continuada tanto de docentes como dos discentes, e da adequação das IES à realidade dinâmica da sociedade e do mercado profissional.

Ainda de acordo com Tardif (2008), os saberes docentes podem ser classificados como pessoais; originários de formações escolares pregressas; oriundos da formação profissional para o magistério; decorrentes de programas e livros didáticos utilizados no trabalho; e provenientes da própria experiência na profissão, na sala de aula e na escola. Além disso, o autor identifica as suas fontes sociais de aquisição, assim como os seus modos de integração e operacionalização no trabalho docente. Ele defende a tese de que "o desenvolvimento do saber profissional é associado tanto às suas fontes e lugares de aquisição quanto aos seus momentos e fases de construção" (p. 68). 
Pimenta e Anastasiou (2011) comentam que as práticas docentes ou educativas constituem um traço cultural compartilhado, o qual possui relação com tudo que acontece em outros âmbitos da sociedade e de suas instituições. Para a transformação destas práticas, segundo as autoras, o caminho é pesquisá-las. Essa tendência tem recebido a denominação de epistemologia da prática profissional, e foi desenvolvida por Tardif (2008).

Para Tardif (2008, p. 255), epistemologia da prática profissional significa " [...] o estudo do conjunto dos saberes utilizados realmente pelos profissionais em seu espaço de trabalho cotidiano, para desempenhar todas as suas tarefas". O autor acrescenta:

[...] se os pesquisadores universitários querem estudar os saberes profissionais da área do ensino, devem sair de seus laboratórios, sair de seus gabinetes na universidade, largar seus computadores, largar seus livros e os livros escritos por seus colegas que definem a natureza do ensino, os grandes valores educativos ou as leis de aprendizagem, e ir diretamente aos lugares onde os profissionais de ensino trabalham, para ver como eles pensam e falam, como trabalham na sala de aula, como transformam programas escolares para torná-los efetivos, como interagem com os pais dos alunos, com seus colegas, etc. (Tardif, 2008, p. 258).

Esta recomendação, de certa forma, é similar a um dos objetivos deste trabalho, em particular no que diz respeito ao que os docentes fazem na sua prática de ensino, tendo em vista a lacuna entre a atual cultura organizacional acadêmica (COA) e a dinâmica realidade social. Esta realidade, por sua vez, fornece novos inputs para que a IES possa retroalimentar a sua COA, atualizando as práticas docentes e currículos, entre outros.

Em ampla revisão de literatura, Caena (2011) comenta as prioridades da União Europeia para melhorar a qualidade dos docentes de ensino superior (ES), por meio de rigorosa revisão na sua formação, de acordo com as conclusões dos Conselhos de Educação de 2007 a 2010, ligados à Comissão Europeia. Neste trabalho, a autora também discorre sobre as mais variadas competências, habilidades e práticas docentes necessárias a um processo de excelência no ES.

Um aspecto fundamental é a necessidade de melhorar as competências e práticas dos professores, bem como promover valores e atitudes profissionais, mediante os seguintes requisitos: a) conhecimento especializado de assuntos; b) competências pedagógicas, abrangendo: 1) dar aulas combinando técnicas alternativas; 2) utilizar as TICs; 3) ensinar 
competências transversais; 3) criar escolas atraentes e seguras; e 4) desenvolver culturas/atitudes de prática reflexiva, de pesquisa, de inovação, colaboração e autonomia do educando.

Segundo Caena (2011), os conhecimentos, práticas e valores docentes, considerados como os mais atuais e relevantes entre os que estão em sua pesquisa, são mostrados na Tabela 13.

Tabela 13

Conhecimentos, práticas e valores docentes

\begin{tabular}{|c|c|}
\hline Tipo & Descrição \\
\hline Conhecimentos & $\begin{array}{l}\text { c1) do conteúdo da disciplina; } \\
\text { c2) de aspectos pedagógicos a ; } \\
\text { c3) de desenvolvimentos curriculares } \\
\text { c4) de ciências fundamentais para o ES (históricos, filosóficos, interculturais, } \\
\text { psicológicos, sociológicos); } \\
\text { c5) contextuais; aspectos institucionais; e organizacionais das políticas educativas; } \\
\text { c6) questões de inclusão e diversidade; } \\
\text { c7) novas tecnologias (TIC's); } \\
\text { c8) psicologia do desenvolvimento; } \\
\text { c9) de processos de integração de grupos e dinâmicas, teorias de aprendizagem, } \\
\text { problemas de motivação; e } \\
\text { c10) de avaliação e processos de avaliação e métodos. }\end{array}$ \\
\hline Práticas docentes & $\begin{array}{l}\text { p1) planejamento, gerenciamento e coordenação de ensino; } \\
\text { p2) utilização de materiais e tecnologias de ensino; } \\
\text { p3) gestão de alunos e grupos; } \\
\text { p4) acompanhamento e avaliação da aprendizagem; } \\
\text { p5) colaboração com colegas, pais e serviços sociais; } \\
\text { p6) habilidades de negociação; } \\
\text { p7) colaboração, reflexividade, habilidades interpessoais para a aprendizagem em } \\
\text { comunidades profissionais; } \\
\text { p8) capacidade de se adaptar à dinâmica multinível com influências cruzadas (a } \\
\text { partir de políticas governamentais para aluno, em sala de aula e da escola } \\
\text { dinâmica); } \\
\text { p9) capacidade de tirar conclusões e decisões com base em interpretações de } \\
\text { provas e dados. }\end{array}$ \\
\hline Valores docentes & $\begin{array}{l}\text { v1) consciência epistemológica (ou seja, sobre as questões relevantes das } \\
\text { características e evolução histórica da área de assunto e seu status, como } \\
\text { relacionado a outras áreas); } \\
\text { v2) disposição para mudanças; } \\
\text { v3) compromisso de promover a aprendizagem de todos os alunos; } \\
\text { v4) disposição para promover atitudes e práticas democráticas nos alunos como } \\
\text { futuros cidadãos; } \\
\text { v5) disposição para a flexibilidade e aprendizagem contínua; e } \\
\text { v6) disposição para examinar, discutir, questionar até suas próprias práticas. }\end{array}$ \\
\hline
\end{tabular}

Nota. Fonte: Adaptado de Caena, F. (2011). Teachers' core competences: requirements and development. European Commission.

${ }^{a}$ Métodos e técnicas de ensino, conhecimentos sobre materiais curriculares, contextos e objetivos da disciplina, dificuldades recorrentes de aprendizagem de conteúdos específicos 
Segundo a Association to Advance Collegiate Schools of Business (AACSB, 2013), as qualificações para o exercício da docência, no caso, em cursos nas áreas de Contabilidade e/ou Negócios, são subdivididas em qualificações acadêmicas (Qas) e qualificações profissionais (Qps). Embora não esteja expressamente escrito no texto, parece razoável presumir que nas “Qas” estejam incluídos aspectos pedagógicos.

A AACSB é uma organização global, sem fins lucrativos, de instituições de ensino, empresas e outras entidades dedicadas ao avanço da gestão da educação. Fundada em 1916, a AACSB fornece a seus membros uma variedade de produtos e serviços para ajudá-los na melhoria contínua de seus programas de negócios e escolas.

As publicações da AACSB fornecem orientações e diretrizes para que os programas de Administração e Contabilidade possam ter recursos adequados e qualificados para a melhoria contínua dos programas dos cursos e das próprias IES. A organização recomenda que, dependendo da missão e do programa de contabilidade da IES, as Qas e Qps devem ser implantadas em número suficiente para apoiar a 'alta qualidade geral' da instituição em todos os seus programas acadêmicos. O corpo docente e os currículos desenvolvidos e implantados devem resultar de decisões estratégicas dentro da IES.

Segundo esta entidade, as Qas devem ser conduzidas e desempenhadas por docentes com nível de doutorado (Contabilidade ou similar) ou de outro curso significativamente especializado, para fornecer a liderança necessária à produção da contribuição científica e intelectual, visando apoiar a pesquisa e o ensino da escola de Negócios contidos na missão do programa de Contabilidade. Contudo, isso não deve diminuir o papel que as Qps podem ter na docência e na produção de contribuições intelectuais.

As recomendações da AACSB (2013) é que as Qps devem ser executadas, na maioria dos casos, por docentes que possuam: pelo menos um mestrado (ou qualificação equivalente) em uma disciplina ou área relacionada à área de sua responsabilidade de ensino; experiência profissional no momento da contratação, condizente com o nível de responsabilidade e com a área de ensino pela qual se tornará responsável; e desenvolvimento contínuo, mostrando a preocupação com a manutenção do capital intelectual necessário ao ensino. 
Segundo a AACSB (2013), as "Qas”, em nível global, devem ter pelo menos 50\% de peso sobre o total de recursos necessários à docência. Juntas, as "Qas" e "Qps" devem possuir não menos que $90 \%$ do total dos recursos docentes. Os $10 \%$ restantes são para outras aptidões não expressas no texto original, mas se presume que sejam qualificações pessoais.

Com base nas informações e conceitos apresentados nesta seção, foi efetuada uma compilação com o propósito de elaborar um quadro de referência que pudesse indicar, comparativamente, práticas com características acadêmicas versus práticas com características profissionais e/ou pessoais. Essas informações, apresentadas na Tabela 14, visam servir de apoio ao capítulo que trata dos resultados e análise da cultura organizacional acadêmica (COA) das IES.

Tabela 14

Uma síntese das práticas e/ou competências docentes

\begin{tabular}{|c|c|c|}
\hline \multirow[b]{2}{*}{$\mathbf{N}^{\circ}$} & \multicolumn{2}{|c|}{ PRÁTICAS E/OU COMPETÊNCIAS DOCENTES } \\
\hline & ACADÊMICAS & PROFISSIONAIS E/OU PESSOAIS \\
\hline 01 & Ter domínio dos conteúdos das disciplinas & $\begin{array}{l}\text { Ter experiência profissional na área, aplicando-a, } \\
\text { sempre que possível, aos conteúdos ministrados }\end{array}$ \\
\hline 02 & $\begin{array}{l}\text { Conhecer teorias de aprendizagem e } \\
\text { processos de integração de grupos }\end{array}$ & $\begin{array}{l}\text { Possuir habilidades de negociação e resolução de } \\
\text { conflitos grupais }\end{array}$ \\
\hline 03 & $\begin{array}{l}\text { Promover a integração dos conteúdos (inter, } \\
\text { multi e transdisciplinares) }\end{array}$ & $\begin{array}{l}\text { Potencializar a aprendizagem envolvendo todo o } \\
\text { cérebro (integração do racional com o emocional, } \\
\text { intuitivo e holístico) }\end{array}$ \\
\hline 04 & $\begin{array}{l}\text { Possuir comprovada experiência pedagógica } \\
\text { e didática (planejar e conduzir o processo) }\end{array}$ & $\begin{array}{l}\text { Ter experiência para enfrentar os deveres e dilemas } \\
\text { éticos da profissão de professor e missão de educador }\end{array}$ \\
\hline 05 & $\begin{array}{l}\text { Saber construir e atualizar: matriz curricular e } \\
\text { proposta pedagógica do curso }\end{array}$ & $\begin{array}{l}\text { cado para a sala de } \\
\text { prendizado }\end{array}$ \\
\hline 06 & $\begin{array}{l}\text { Possuir rigor metodológico, mas ter alguma } \\
\text { flexibilidade }\end{array}$ & Transmitir competência, seriedade e generosidade \\
\hline 07 & $\begin{array}{l}\text { Incentivar o pensamento reflexivo sobre a } \\
\text { prática, a inovação e espírito colaborativo }\end{array}$ & $\begin{array}{l}\text { Aproveitar os erros como fonte para pesquisa e a } \\
\text { reflexão sobre o aprender a aprender }\end{array}$ \\
\hline 08 & $\begin{array}{l}\text { Ter domínio de classe e envolver os } \\
\text { discentes, respeitando seus saberes e } \\
\text { autonomia }\end{array}$ & $\begin{array}{l}\text { Possuir bom nível de relacionamento interpessoal, } \\
\text { sabendo ser disciplinado e desenvolver disciplinar }\end{array}$ \\
\hline 09 & $\begin{array}{l}\text { Ser curioso e despertar a curiosidade e/ou } \\
\text { pesquisar e estimular a pesquisa }\end{array}$ & $\begin{array}{l}\text { Fornecer estudos de casos adaptados para desenvolver } \\
\text { trabalho em equipe e maturação do formando }\end{array}$ \\
\hline 10 & $\begin{array}{l}\text { Ser humilde, tolerante e respeitar os saberes e } \\
\text { a autonomia dos discentes }\end{array}$ & $\begin{array}{l}\text { Ter bom senso, saber escutar e ter disponibilidade para } \\
\text { o diálogo }\end{array}$ \\
\hline 11 & $\begin{array}{l}\text { Ter domínio das TIC's e conhecer ciências } \\
\text { fundamentais (cultura geral, filosofia, } \\
\text { psicologia, sociologia, informática etc.) }\end{array}$ & $\begin{array}{l}\text { Possuir experiências de base tecnológica, matemática, } \\
\text { científica e digital }\end{array}$ \\
\hline 12 & $\begin{array}{l}\text { Mostrar convicção de que a mudança é } \\
\text { possível no ensino e na aprendizagem }\end{array}$ & $\begin{array}{l}\text { Mostrar as vantagens de empreender, desenvolver seu } \\
\text { próprio negócio e obter resultados com segurança }\end{array}$ \\
\hline
\end{tabular}


Continuação da Tabela 14

\begin{tabular}{c|l|l}
\hline \multirow{2}{*}{$\mathbf{N}^{\mathbf{0}}$} & \multicolumn{1}{|c}{ PRÁTICAS E/OU COMPETENCIAS DOCENTES } \\
\cline { 2 - 3 } 13 & $\begin{array}{l}\text { ACADÊMICAS } \\
\text { Estar aberto para o novo e ter consciência do } \\
\text { inacabamento (educação continuada) }\end{array}$ & $\begin{array}{l}\text { Estimular o empreendedorismo, as possibilidades de } \\
\text { inovação, enfatizando o aprendizado contínuo }\end{array}$ \\
\hline 14 & $\begin{array}{l}\text { Conhecer as políticas institucionais e } \\
\text { organizacionais ligadas à missão da IES }\end{array}$ & Identificar-se com a IES e com o seu contexto político \\
\hline
\end{tabular}

As 14 práticas relacionadas na Tabela 14 foram agrupadas, de acordo com a descrição de seu conteúdo, em categorias de conhecimentos, visando tornar mais objetivos os comentários referentes a esse quadro, no capítulo que trata dos resultados da pesquisa. Dessa forma, ordenadamente, foram obtidas as seguintes categorias:

a) Conhecimento teórico-profissional (práticas 1 e 2);

b) Conhecimento didático (práticas 3 e 4);

c) Conhecimento docente (práticas 5 e 6);

d) Conhecimento interpessoal e/ou psicológico (práticas 7, 8, 9 e 10);

e) Conhecimento geral (práticas 11, 12, 13 e 14)

É pouco provável que um jovem professor, mesmo com a qualificação de doutor, seja de que área for, e mais especificamente, de um curso de Ciências Contábeis, em nível global, reúna todas essas categorias de conhecimentos. Contudo, o objetivo do quadro de referência é exatamente servir como um norte para o aprimoramento e a educação continuada do docente.

Em geral, conforme observado nas Qas e Qps da AACSB, os docentes, em nível de doutorado e/ou mestrado, devem possuir experiência profissional condizente com as disciplinas que irão ministrar no momento da contratação. Assim, são necessárias experiências vivenciadas em organizações com ou sem fins lucrativos, instituições de ensino médio e/ou superior, e experiência de vida para que o processo de maturação propicie ao docente atingir um nível satisfatório quanto ao domínio dessas categorias.

\subsection{Literatura empírica sobre cultura organizacional}

Nesta seção, são apresentados os principais trabalhos empíricos de pesquisadores sobre cultura organizacional (CO) com o objetivo de servir de suporte para comparações com os 
resultados da pesquisa. Procurou-se selecionar trabalhos que tivessem como teorias subjacentes as abordagens de Schein (2009) e de Denison et al. (2012), a qual também derivou de Schein, pelo fato de ambas, em conjunto, terem sido os principais referenciais deste trabalho, além de Hofstede (2003). Ademais, priorizaram-se trabalhos que tivessem aplicações em IES e/ou tratassem da relevância da CO sobre o desempenho.

Ao final da seção é feita uma síntese, utilizando a análise de conteúdo (Bardin, 1977), com o objetivo de identificar, excetuando a questão da abordagem usada, que foi comum, os principais argumentos e achados dos autores dos referenciais empíricos que tenham relação com a temática desta tese. Esses argumentos foram posteriormente destacados e analisados.

Um dos pioneiros na utilização da CO em universidades foi Tierney (1988), que apresentou um modelo de avaliação das culturas dos departamentos intercolegiais de Atletismo, por meio de um quadro conceitual de trabalho que permitisse fazer a diagnose em faculdades e universidades similares. $O$ trabalho não sugeriu que o entendimento da cultura organizacional seria um antídoto para todos os problemas da administração, nem que o excesso de definições para cultura organizacional tornaria seu estudo sem sentido para administradores e pesquisadores do ensino superior. O modelo utilizado para diagnose foi baseado na teoria de CO de Schein (1985), mais precisamente na sua 'pesquisa clínica', e pode ser visto na Tabela 15. A investigação foi realizada no período de um ano, entre 1984 e 1985, com o uso metodológico de um estudo de caso em uma faculdade pública estadual americana.

Tabela 15

Um quadro conceitual para Cultura Organizacional

\begin{tabular}{ll}
\hline \multicolumn{1}{c}{ Elemento da cultura } & \multicolumn{1}{c}{ Questões-chave } \\
\hline \multirow{2}{*}{ Ambiente } & Como a organização define o seu entorno ambiental? \\
& Qual é a atitude da IES frente ao seu entorno ambiental? (Hostil? Amistosa?) \\
\hline Missão & Como ela é definida? \\
& Como ela é articulada? \\
& Ela é usada como base para decisões? \\
& Em que medida existe acordo? \\
\hline Socialização & Como é a socialização de novos membros? \\
& Como isso é articulado? \\
& O que nós precisamos saber para sobreviver/superar nessa organização? \\
\hline
\end{tabular}


Continuação da Tabela 15

\begin{tabular}{ll}
\hline \multicolumn{1}{c}{ Elemento da cultura } & \multicolumn{1}{c}{ Questões-chave } \\
\hline Informação & O que constitui a informação? \\
& Quem a detém? \\
& Como ela é disseminada? \\
\hline Estratégia & Como as decisões são tomadas? \\
& Qual estratégia é usada? \\
& Quem toma as decisões? \\
& Qual é a penalidade para más decisões? \\
\hline Liderança & O que a organização espera de seus líderes? \\
& Quem são os líderes? \\
& Eles são líderes formais ou informais? \\
\hline
\end{tabular}

Nota. Fonte: Adaptado de Tierney, W. G. (1988). Organizational culture in higher education: Defining the essentials. The Journal of Higher Education, 59(1), 2-21.

As dimensões-chave da cultura, identificadas por Tierney (1988), assim como as questõeschave usadas para entrevistas semiestruturadas, propiciaram a coleta de todas as informações que foram, posteriormente, organizadas para apresentação dos resultados. Dentre os seus principais achados, encontram-se: i) a liderança, na figura do presidente, utilizava, formal e informalmente, diferentes conceitos de cultura; ii) as pessoas que conviviam no ambiente interno da instituição (docentes, técnicos e alunos) percebiam que eram bem informadas dos planos e decisões administrativas, principalmente por meio de processos informais; iii) evidências tais como conversas informais do presidente com os administradores ou caminhar com ele ao redor do campus eram exemplos efetivos do uso informal de tempo; iv) contudo, foi notado que mais coisas deviam ser feitas em relação ao uso efetivo de formalidade ou não com relação ao tempo, espaço e comunicação; e v) o autor ressalta que uma investigação sobre os subconjuntos de culturas forneceria informações muito úteis aos administradores sobre como aumentar o desempenho e reduzir conflitos em subgrupos particulares.

Já Schroeder (2010) propôs desenvolver um modelo para avaliar as características culturais dentro do Departamento Intercolegial de Atletismo em uma Faculdade de Esportes (FCE), devido à ausência verificada de alinhamento entre professores, treinadores e atletas. A construção do trabalho teve como base teórica a abordagem de Schein (2004). A metodologia utilizada foi de natureza qualitativa com uso de estudo de caso. No modelo adaptado pelo autor, foram usadas entrevistas com roteiros semiestruturados contendo quatro questões-chave para cada uma das dimensões ou elementos da cultura identificados por ele. Ele adaptou a denominada 'pesquisa clínica' de Schein e a aplicou em membros da faculdade como 
administradores, professores (treinadores) e atletas (estudantes). As dimensões identificadas foram: cultura institucional; ambiente externo; ambiente interno; e liderança e poder. Schroeder (2010) utilizou o seguinte esquema integrativo, apresentado na Figura 6.

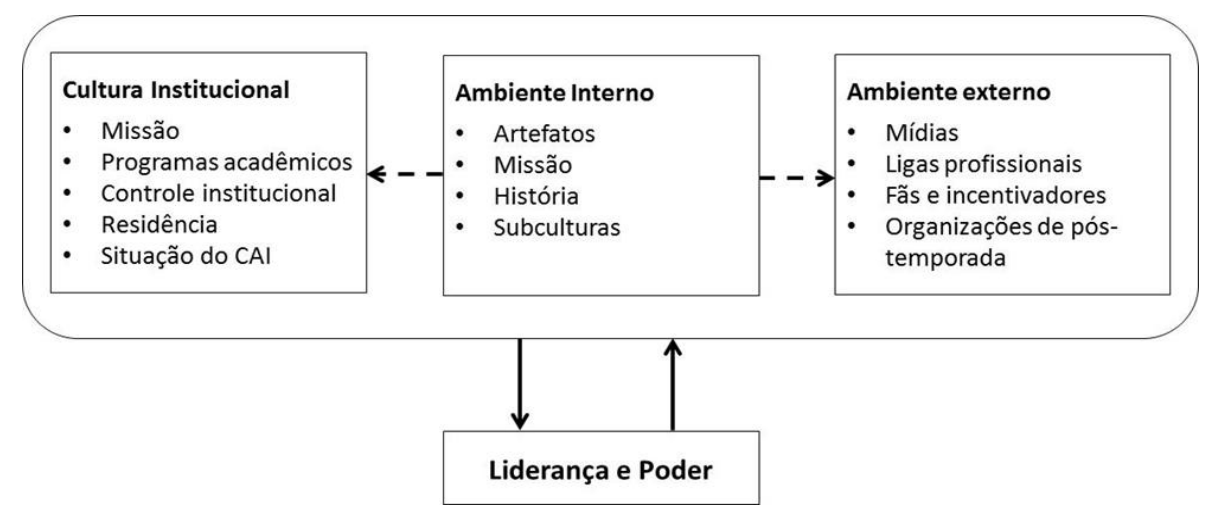

Figura 6. Interação dos elementos do modelo de culturas do Departamento Intercolegial de Atletismo. Fonte: Adaptado de Schroeder, P. J. (2010). A Model for Assessing Organizational Culture in Intercollegiate Athletic (p. 103). Journal of Issues in Intercollegiate Athletics, 3, pp. 98-118.

CAI: Conferência de Afiliação da Instituição (Institution's Conference Affiliation - ICA)

As informações e dados necessários ao estudo foram obtidos por meio de uma série de questões, apresentadas na Tabela 16, para cada uma das quatro dimensões.

Tabela 16

Questões iniciais para investigação da cultura no Departamento Intercolegial de Atletismo da FCE

Elemento da Cultura Questões Chave

Cultura Institucional Qual a missão da Faculdade/Universidade?

A IES é privada ou pública? Quais os requisitos para a residência?

Quais são os valores e pressupostos da IES?

\begin{tabular}{ll}
\hline Ambiente Externo & Qual é o escopo do meio ambiente do departamento? \\
& Quais externalidades influenciam o departamento? \\
& Quão intensas são as interações do departamento com o ambiente? \\
& Qual o ganho ou contribuição do departamento para o meio ambiente? \\
\hline Ambiente Interno & Qual é a história do departamento? \\
& Qual é a missão do departamento? \\
& Quais associações mantêm o departamento? \\
& Quais subculturas existem? \\
& Quais símbolos/artefatos existem? Qual o significado que eles têm? \\
\hline Liderança e Poder & Quem são os líderes formais e informais? \\
& O que a organização espera de seus líderes? \\
& Quais são as principais fontes de poder? \\
& Como são tomadas as decisões? \\
\hline
\end{tabular}

Fonte: Adaptado de Schroeder, P. J. (2010). A Model for Assessing Organizational Culture in Intercollegiate Athletic.

Journal of Issues in Intercollegiate Athletics, 3, 98-118. 
Os principais resultados de Schroeder (2010) são: i) o caso ilustra que os aparentes conflitos de valor podem ser evidenciados pelos baixos níveis de competição intercolegial, embora as fontes desses conflitos de valor variem; ii) há forte evidência do papel da liderança dos treinadores na determinação da cultura da FCE; iii) os líderes internos puderam criar suposições consistentes entre suas universidades e a FCE, por meio de trabalho colaborativo e regular com os atletas (estudantes); iv) mesmo com a limitação do programa da FCE, o caso ilustra claramente a necessidade de um quadro conceitual específico para o seu departamento intercolegial de atletismo; e v) novas pesquisas deverão usar modelos similares para averiguar como as subculturas existentes no ambiente interno influenciam os valores do departamento, descobrindo o impacto da história na sua cultura.

Embora não aplicado a uma IES, um trabalho clássico sobre CO é o de Denison e Mishra (1995), cujo objetivo foi desenvolver um modelo que contemplasse a relação entre cultura organizacional e eficácia, com base em estudos de caso e surveys (levantamentos). As bases do trabalho apoiam-se em Schein. A importância desse trabalho está atrelada ao fato de a abordagem desses autores ter evoluído de tal forma que se transformou num dos referenciais teóricos desta tese na subseção 2.3.2, tendo sido parcialmente usada na elaboração do modelo utilizado no capítulo 4 deste trabalho.

$\mathrm{O}$ modelo dos autores foi concebido utilizando quatro traços da $\mathrm{CO}$ : envolvimento; consistência; adaptabilidade; e missão, os quais foram examinados por meio de duas metodologias e dois estudos interligados. Na primeira usaram-se estudos de caso qualitativos de cinco empresas para identificar as características e a natureza do seu vínculo com a efetividade; e na segunda foi usado um estudo quantitativo que permitiu uma análise exploratória das percepções de executivos sobre essas quatro características, e sua relação com medidas subjetivas e objetivas de efetividade, em uma amostra de 764 organizações. $\mathrm{O}$ modelo utilizado no primeiro estudo é apresentado na Figura 7: 


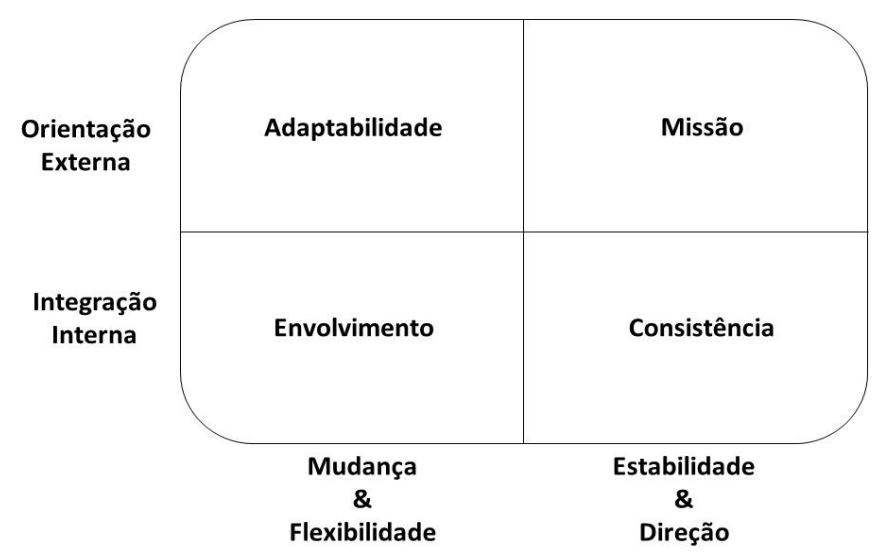

Figura 7. Modelo de quatro forças da cultura segundo Denison e Mishra (1995)

Fonte: Denison, D., \& Mishra, A. K. (1995). Toward a theory of organizational culture and effectiveness (p. 216). Organization science, 6(2), 204-223.

De acordo com os autores, umas das razões para a elaboração deste modelo foi mostrar a aparente forma linear de integração entre as quatro hipóteses básicas. A segunda metodologia faz uso de um teste exploratório com as mesmas quatro hipóteses, examinando a ligação entre esses quatro traços culturais e a eficácia. Os resultados foram comparados com um conjunto de medidas de eficácia, incluindo medidas subjetivas e objetivas de rentabilidade, qualidade, crescimento das vendas, satisfação e eficácia global.

Entre os principais achados dos autores estão: i) cada um dos quatro traços culturais mostrou associação positiva significativa com uma ampla gama de medidas subjetivas e objetivas de eficácia organizacional, bem como ligações entre traços específicos interpretáveis e critérios específicos de eficácia; ii) esses resultados apoiam uma das premissas básicas de muitos pesquisadores da área de cultura: que as culturas das organizações têm uma influência importante sobre a eficácia; e iii) os resultados sustentam o valor preditivo dos traços culturais e ajudam a ilustrar a complementaridade de métodos qualitativos e quantitativos para o estudo de culturas organizacionais. Dois dos traços, envolvimento e capacidade de adaptação, foram indicadores de flexibilidade, abertura e capacidade de resposta, sendo fortes preditores de crescimento. As outras duas características, consistência e missão, foram indicadores de integração, direção e visão, sendo melhores preditores de rentabilidade.

Outro trabalho sobre CO em IES foi o de Locke e Guglielmino (2006), que teve como propósito fornecer à liderança ou gestão de uma faculdade, localizada na região sudeste dos 
Estados Unidos, uma forma mais abrangente e diferenciada de compreensão do papel das subculturas nos processos de mudança planejada na instituição. A pesquisa também buscou saber: a) em quais níveis as diferenças entre as subculturas são mais evidentes; b) confirmar a existência de subculturas; c) identificar temas dentro de cada subcultura sobre percepções de mudança organizacional; e d) analisar as semelhanças e diferenças entre os grupos de subculturas em relação à percepção de mudança planejada.

A base teórica utilizada pelos autores foi o modelo de três camadas de Schein. A metodologia utilizada foi qualitativa, com o uso de estudo de caso único aplicado em uma faculdade comunitária. Na coleta das informações e dados necessários à pesquisa, foram utilizadas técnicas como grupo focal, entrevistas individuais, observação participante, aplicação de questionário com anonimato e revisão de documentos do arquivo da faculdade. Doze a 15 membros de cada subcultura participaram dos grupos focais, num total de 47 pessoas. As sessões desses grupos basearam-se no modelo de 'pesquisa-ação' de Schein, para identificar suposições culturais relevantes e avaliar o grau em que essas suposições ajudam ou prejudicam algum propósito estratégico que preocupa o grupo, no caso, a mudança planejada ampla.

Como principais resultados, encontram-se: i) a cultura institucional funcionou como fator primordial para o sucesso de programas de mudança; no entanto, pouca pesquisa foi realizada sobre a influência de subculturas organizacionais em programas de mudança planejada em faculdades comunitárias; ii) o grupo de subculturas respondeu de forma distinta à experiência sobre a influência da mudança planejada na faculdade comunitária, levando a várias estratégias para programas mais efetivos de mudança planejada; iii) as subculturas mostraram diferenças significativas nas formas pelas quais os participantes experimentaram, responderam e influenciaram a mudança planejada; e iv) o papel dos líderes organizacionais no planejamento e na implementação da mudança, além de estratégias que podem se revelar eficazes em acomodar influências subculturais neste tipo de mudança.

Já o trabalho de Uprety e Chhetri (2014) sobre CO em IES trouxe uma contribuição adicional a esta tese, porque mostra como os autores analisaram a relação entre a cultura universitária e a satisfação do aluno, buscando saber, principalmente, quais as dimensões da cultura que mais afetam a satisfação. Também examinaram a magnitude da relação entre as 
dimensões de cultura das faculdades, percebidas pelos alunos, e o seu nível de satisfação. A pesquisa foi realizada com 251 estudantes de várias faculdades (pertencentes a pelo menos quatro universidades), do nível Bachelor in Business Administration (BBA), localizadas em dois distritos do Nepal, usando o Modelo de Cultura Organizacional de Denison de quatro dimensões. De acordo com os autores, “estas quatro dimensões são consistentes com a observação de Schein (1990) de que a cultura é desenvolvida como uma organização que aprende a lidar com os dois problemas de adaptação externa e integração interna" (p.78). O modelo dos autores está simplificado no esquema, apresentado na Figura 8.

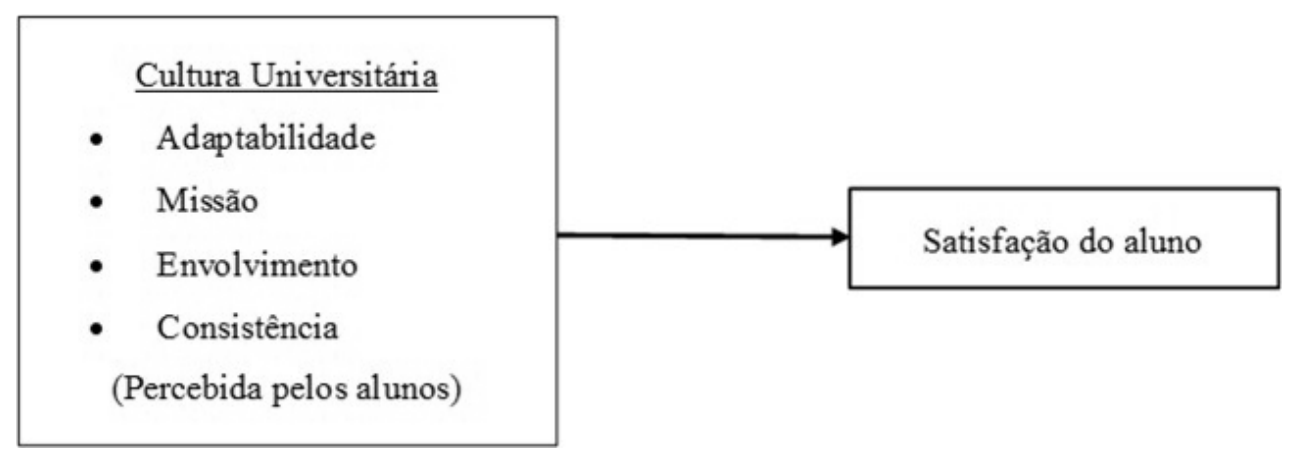

Figura 8. Quadro conceitual do estudo de Uprety e Chhetri (2014)

Fonte: Adaptado de Uprety, R., \& Chhetri, S. B. (2014). College Culture and Student Satisfaction (p. 82). Journal of Education and Research, 4(1), 77-92.

Os autores utilizaram metodologia quantitativa para determinação das médias de quatro variáveis, cada uma representando uma dimensão da cultura. Uprety e Chhetri (2014) formularam cinco hipóteses, sendo quatro delas sobre a associação entre uma das quatro dimensões e a satisfação dos alunos. Na quinta hipótese, os autores presumiram que a magnitude da associação resultaria, em ordem decrescente, nas dimensões adaptabilidade, missão, envolvimento e consistência.

Entre as principais conclusões dos autores, podemos citar: i) a cultura da faculdade desempenha um papel essencial na satisfação dos alunos; ii) as faculdades que priorizam as dimensões da cultura adaptabilidade, envolvimento e consistência são as que têm mais alunos satisfeitos, comprovando três das hipóteses; iii) este estudo reforça o argumento de que os alunos de qualquer IES, após alguns anos de estudo, parecem tornar-se parte da instituição, e desenvolvem internamente uma compreensão da sua cultura; iv) a satisfação dos alunos contribui para preservar um papel significativo no sucesso das instituições de ensino em um 
ambiente competitivo; v) a forte associação entre a satisfação dos alunos e as dimensões de cultura da universidade é uma indicação de que os profissionais da educação precisam criar um tipo de cultura organizacional que afete positivamente a satisfação do aluno para alcançar melhor desempenho; e vi) as dimensões de cultura da faculdade que mais se relacionam com a satisfação do aluno são, em ordem decrescente, o envolvimento, a adaptabilidade e a consistência, portanto, não validando a ordem da quinta hipótese.

O trabalho de Hogan e Coote (2014) não trata de CO em IES, mas traz uma contribuição sobre a gestão da CO como forma de influenciar o desempenho. Seu objetivo específico foi proporcionar uma compreensão mais clara das relações entre as distintas camadas de cultura e os comportamentos inovadores de uma organização. Para tanto foi desenvolvido um modelo empírico, com metodologia quantitativa, e posterior análise em empresas de serviços profissionais, baseado na abordagem conceitual de Schein (1992). A justificativa foi fornecer uma visão mais completa das características culturais fundamentais e processos que levam a comportamentos inovadores dentro de um contexto baseado no conhecimento. O modelo desenvolvido se apoiou no esquema apresentado na Figura 9.

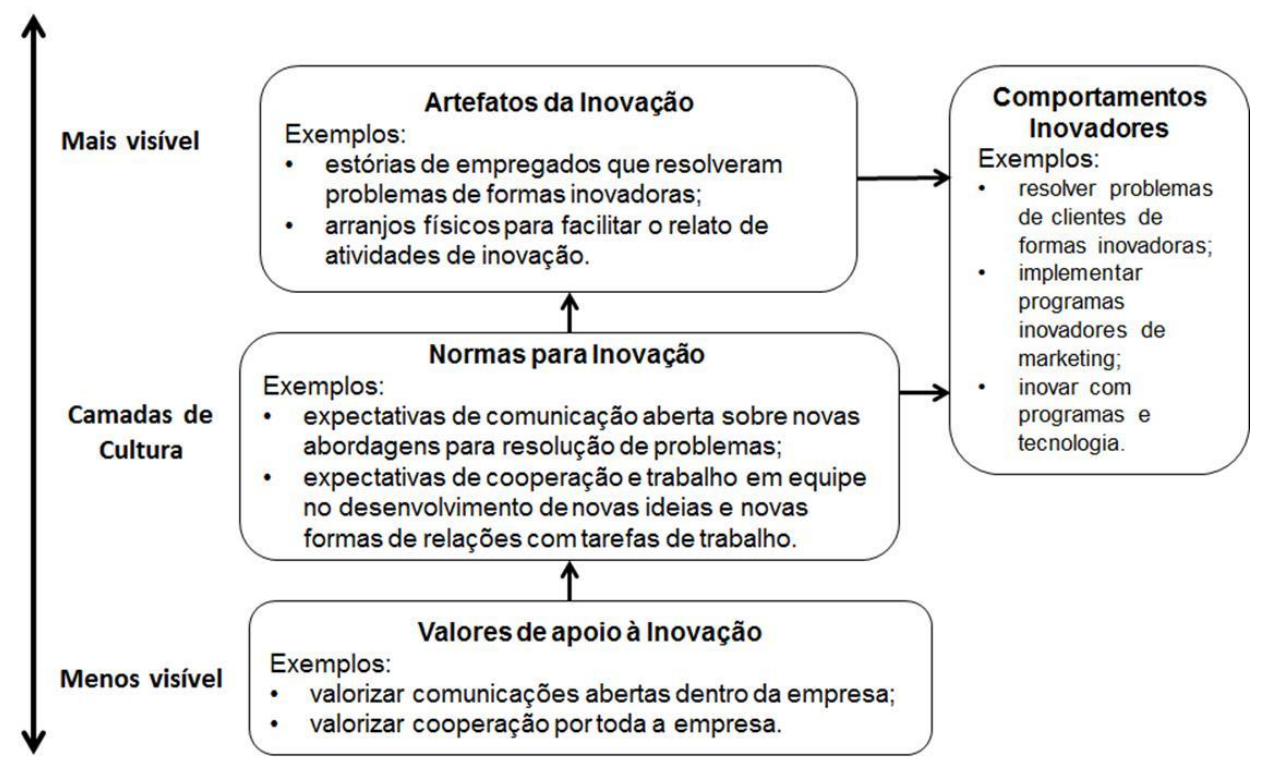

Figura 9. Camadas de uma cultura organizacional que apoia a inovação

Fonte: Adaptado de Hogan, S. J., \& Coote, L. V. (2014). Organizational culture, innovation, and performance: A test of Schein's model (p. 1610). Journal of Business Research, 67(8), 1609-1621 
Os principais achados de Hogan e Coote (2014) sugerem que: i) os valores de apoio à inovação, por si só, não levam ao aumento do desempenho; ii) o processo a partir de valores de resultados de desempenho é, em parte, dependente de normas para a inovação, artefatos de inovação e comportamentos inovadores; iii) o estudo forneceu explicação plausível sobre os processos culturais que apoiam a inovação organizacional; e iv) foi importante verificar a forma como as camadas de cultura organizacional, especialmente as normas, artefatos e comportamentos inovadores, mediam parcialmente os efeitos dos valores que apoiam a inovação em medidas de desempenho da empresa.

Como a pesquisa desta tese trata especificamente de CO em IES públicas, foi importante ter uma visão sobre o que os pesquisadores pensam sobre $\mathrm{CO}$ em organizações públicas. Foi o que propuseram Souza Pires e Macêdo (2006) ao apresentar e discutir conceitos que contribuem para a compreensão de aspectos e traços relacionados à cultura organizacional de organizações públicas (OP) no Brasil. Os autores empregaram uma abordagem qualitativa de cunho teórico-epistemológico, baseando-se em uma compilação bibliográfica de vários autores estrangeiros e nacionais sobre o tema, entre eles Fleury, Frost, Schein e Hofstede.

Entre os seus achados, estão: i) o desenho organizacional público apresenta formas bastante complexas e níveis hierárquicos múltiplos; ii) as OP demonstram um paternalismo que gera alto controle de movimentação de pessoal, cargos e comissões; iii) as OP possuem estruturas altamente estáveis que resistem, de forma generalizada, a mudanças de procedimentos e à incorporação de novas tecnologias; iv) as OP possuem cultura burocrática, corporativa e avessa ao empreendedorismo, que orienta a prática de gestão; v) as OP são vulneráveis à interferência política externa; vi) esse conjunto de fatores geralmente leva a organização a descontinuidades na gestão e ao reformismo de projetos de curto prazo, com conflitos de objetivos e gestão não profissional; e vii) além desses aspectos, essas organizações geralmente possuem características centralizadoras e estruturas rígidas que não são orientadas para a eficácia e para a efetividade. Concluem os autores que apenas com projetos estruturais, normativos e focados nos servidores (e trabalhadores), de forma que possa ser assegurada a continuidade dos projetos, essas organizações conseguirão lograr êxito.

Baseado na hipótese de que este tema ainda é pouco explorado no país, procurou-se verificar como está a produção científica sobre CO no Brasil, haja vista a grande variedade de 
trabalhos sobre este tema no exterior. Silva e Fadul (2010) analisaram a produção científica sobre cultura organizacional em organizações públicas no Brasil, no período de 1997 a 2007. A premissa básica adotada foi a relevância, tanto do ponto de vista de pesquisa quanto do ponto de vista prático, uma vez que, para o sucesso da reforma do Estado, implementada a partir de 1995, foi dada forte ênfase à questão da mudança cultural nas organizações públicas.

Os autores identificaram, intencionalmente, nove periódicos editados no país - Revista de Administração da USP; Revista de Administração de Empresas; Revista de Administração de Empresas eletrônica; Organização \& Sociedade; Revista de Administração Pública; Revista de Administração Contemporânea; Revista de Administração Contemporânea eletrônica; Brazilian Administration Review; e Cadernos EBAPE.BR - e cinco Anais de congressos realizados no Brasil, considerados representativos da área: Encontro Nacional da ANPAD; Encontro de Estudos Organizacionais; Encontro de Estratégia; Encontro de Gestão de Pessoas e Relações de Trabalho; e Encontro de Administração Pública e Governança.

Silva e Fadul (2010) identificaram 440 artigos pelo título. Após verificação preliminar dos objetivos, o número caiu para 80 artigos, e, após leitura, foram selecionados 47 . A produção foi analisada a partir dos aspectos relativos às características da pesquisa, tais como métodos de pesquisa, instrumentos de medida, modelo de tratamento dos dados, teorias de base, vertente teórica e o alinhamento dos pesquisadores com o tema analisado.

Entre as principais conclusões, Silva e Fadul (2010) destacaram: i) os resultados revelaram uma produção muito baixa nesta temática (apenas 47 trabalhos publicados no período de 11 anos); ii) não perceberam continuidade na produção de pesquisa voltada especificamente para os estudos culturais em organizações públicas, pois os autores pesquisados, em sua maioria, publicaram apenas um trabalho neste período sobre este tema; iii) o número de autores envolvidos direta e simultaneamente nesta área de pesquisa, neste período, não passou de 15; iv) $62 \%$ dos trabalhos usaram o método qualitativo, e $92 \%$ empregaram o estudo de caso; e v) além da carência de pesquisas nesta área, sua distribuição ocorreu em poucos estados brasileiros: a região Norte não possui trabalho algum sobre o tema; as regiões Sudeste e Sul tiveram, conjuntamente, 31 trabalhos; a região Nordeste, 10; e a região Centro-oeste, seis. 
Em resumo, após a análise de conteúdo destes oito trabalhos, verificou-se que seis deles, com pequenas distinções entre si, objetivaram desenvolver modelos para melhor compreender e/ou verificar a relação entre a cultura das entidades pesquisadas e o nível de desempenho dos seus resultados. Um dos trabalhos verificou a produção científica sobre CO no Brasil, e outro, a identificação de traços culturais da $\mathrm{CO}$, existentes nas organizações públicas do país.

Quanto à metodologia, seis utilizaram abordagens qualitativas, sendo quatro estudos de caso, dos quais um combinou técnicas qualitativas com quantitativas. Apenas dois dos trabalhos utilizaram somente metodologia quantitativa. O campo empírico de quatro trabalhos abrangeu IES, enquanto dois tiveram corporações como objeto. Dos outros dois, um tratou da produção científica sobre $\mathrm{CO}$ no Brasil, e o outro de $\mathrm{CO}$ de entidades públicas.

Seis trabalhos tiveram em comum, nos seus achados, a importância da liderança como um dos elementos da cultura que mais influencia a eficácia no desempenho de forma geral, incluindo o trabalho que trata da relação entre dimensões da cultura e nível de satisfação dos estudantes. Estes seis trabalhos também apresentaram em comum a característica de que os processos ou dimensões culturais estão relacionados positivamente com melhores resultados no desempenho. Já o trabalho que procurou identificar traços culturais de CO em organizações públicas constatou que a cultura desse tipo de organização, de forma geral, é burocrática e avessa ao empreendedorismo, além de centralizadora, com estruturas rígidas de poder e não orientadas (liderança) para a obtenção de eficácia e efetividade. 


\section{METODOLOGIA E PROCEDIMENTOS}

Neste capítulo são apresentadas as estratégias metodológicas, as técnicas e os procedimentos utilizados na pesquisa. O capítulo compõe-se de quatro seções. Na primeira é feita uma contextualização do percurso metodológico. Na segunda, são abordados os aspectos da população analisada. A terceira é dedicada à explicação da Técnica do Discurso do Sujeito Coletivo (DSC). Por fim, na quarta, são detalhados os procedimentos de trabalho de campo na coleta das informações e dados, e a forma de tratamento destes para posterior análise.

\subsection{Percurso metodológico}

Trata-se de uma metodologia de predomínio qualitativo, de cunho exploratório e de natureza empírico-analítica e descritiva. A variável de estudo é a cultura organizacional acadêmica (COA) de IES que mantêm graduação em Ciências Contábeis. A priori, a estratégia utilizada, pelas características da questão e objetivos da pesquisa, baseou-se na Abordagem Etnográfica, com o uso de entrevistas em profundidade com elementos da Observação Participante, a técnica do Discurso do Sujeito Coletivo (DSC) e pesquisa documental. Usou-se ainda, de forma complementar, uma técnica de questionário (survey), o qual foi aplicado em discentes dos dois cursos das IES escolhidas.

A pesquisa etnográfica, de origem socioantropológica, "tem por objeto os modos de vida de grupos sociais" (Martins \& Theóphilo, 2009, p.75). Este tipo de pesquisa busca descrever o sistema de significados culturais de um determinado grupo, devido a sua característica essencial de buscar fontes múltiplas de informações e evidências para obtenção de perspectivas distintas sobre a situação pesquisada. Acrescentam os autores que a coleta dessas informações, dados e evidências é efetuada por meio da observação participante.

Martins e Theóphilo (2009) mencionam ainda que “[...] A Observação Participante proporciona o grau de diferencial da pesquisa etnográfica, por propor a imersão do pesquisador no meio de vida dos pesquisados" (p.75). A característica fundamental da observação participante é buscar descrever os detalhes da forma mais objetiva possível, estar vigilante para evitar interpretações e inferências, pondo de lado os seus próprios preconceitos 
e julgamentos imediatos (Angrosino, 2009). Este autor acrescenta que as questões a serem feitas aos entrevistados não devem se fixar a uma lista, devendo apenas servir como um roteiro para os assuntos principais da conversa.

O tema cultura organizacional $(\mathrm{CO})$ tem representado um desafio para pesquisadores buscarem percursos metodológicos inovadores, interessantes e consistentes (Fleury, 1996). Esta autora conseguiu distinguir três tipos de posturas do pesquisador quanto à metodologia: a) Empiricista, cuja característica seria a de um fotógrafo da realidade social; b) Antropólogo, cuja característica seria a de procurar agir ora como observador, ora como observador participante, vivenciando as várias facetas da organização pesquisada, desde que esta lhe permitisse o acesso; e c) Clínico ou Terapeuta, cuja característica principal seria a de ser contatado pela empresa que necessita de ajuda para prover insights sobre a organização e como esta poderia ser ajudada mediante uma 'terapia'. Dessas posturas, a terceira possui mais uma conotação de consultoria (Fleury, 1996). A postura utilizada neste trabalho está mais identificada com o segundo tipo.

A decisão pela entrevista em profundidade, usando questões-chave como guia, decorreu de sua importância na investigação social para compreender aspectos mais complexos, ligados parcialmente à psicologia social do grupo em questão. As entrevistas em profundidade e semiestruturadas são geralmente mais apropriadas para pesquisas no meio educacional; elas fornecem uma combinação desejável de objetividade e profundidade e muitas vezes permitem a coleta de dados valiosos que não poderiam ser obtidos com sucesso por qualquer outra abordagem (Borg \& Gall, 1979). A entrevista semiestruturada normalmente é conduzida por meio de um roteiro básico, mas que permite liberdade ao pesquisador para acrescentar novas questões para melhor atingir os seus objetivos na pesquisa (Martins \& Theóphilo, 2009).

$\mathrm{Na}$ entrevista semiestruturada, o pesquisador deve ouvir os sujeitos e suas perspectivas com o propósito de desvelar suas crenças e valores por meio de suas experiências, tanto na formação como no exercício das atividades acadêmicas. A aplicação de técnicas combinadas visou tornar a investigação mais consistente, buscando minimizar o tempo sem comprometer a qualidade, e, consequentemente, o investimento na realização da coleta. Com o uso da Técnica do DSC nas informações coletadas, foi possível organizá-las em expressões-chave, 
ideias centrais, ancoragens, categorias (Lefevre \& Lefevre, 2012), explicitadas na seção 3.3, e, por fim, os DSC sucintos e concatenados, propiciando melhor interpretação e análise.

Sobre questões investigativas úteis na observação participante, Angrosino (2009) destaca formas que podem ser usadas, tais como: a) assentimentos neutros como 'sim, eu compreendo'; b) repetir o que a pessoa respondeu, mas em forma de questão, para se assegurar de que entendeu corretamente; c) pedir mais informações; d) pedir esclarecimento de aparentes contradições; e) pedir opinião sobre algo mencionado na resposta que seja relevante para a pesquisa; f) pedir esclarecimento de uma palavra ou expressão; g) solicitar listas de coisas, visando obter um melhor entendimento de como os membros de um grupo classificam e organizam o mundo a seu redor; h) pedir que o entrevistado faça narrativas de experiências.

\subsection{Caracterização da população e acesso às IES.}

A população objeto do estudo são dois cursos de graduação em Ciências Contábeis no Brasil, por meio de seus atores, que compõem a COA das duas IES que mantêm essas graduações, no caso os docentes, coordenadores de curso e discentes. Adotou-se a amostragem por acessibilidade, condicionada ao aspecto de que as IES e os participantes pudessem ser selecionados de forma colaborativa. Além disso, as IES deveriam possuir uma estrutura já consolidada, indicando certo grau de maturação da sua cultura organizacional.

As IES escolhidas foram a Universidade de São Paulo [USP] e a Universidade Estadual de Feira de Santana [UEFS]. Em particular, na USP selecionou-se o curso de graduação em Ciências Contábeis, ofertado pelo Departamento de Contabilidade e Atuária (EAC) da Faculdade de Economia, Administração e Contabilidade [FEA]. Da mesma forma, na UEFS, selecionou-se o curso de graduação em Ciências Contábeis ofertado pelo Departamento de Ciências Sociais Aplicadas (DCIS). Estas duas IES têm em comum, além das características de serem públicas e estaduais, um convênio para realização do Dinter ${ }^{12}$, porém pertencem a regiões bem distintas: a USP fica na Região Sudeste; e a UEFS, na Região Nordeste.

\footnotetext{
${ }^{12}$ Doutorado Interinstitucional iniciado em 2011, por meio de convênio entre a UEFS e a FEA/USP, com a adesão, também, de outras universidades públicas do Estado da Bahia.
} 
A principal justificativa para a escolha das duas IES foi a facilidade de acesso a elas e o fato de ambas serem universidades públicas estaduais. Embora as duas IES situem-se em planos bem distintos quanto ao seu grau de qualificação e importância atual no Brasil, esse aspecto não foi considerado importante porque não se buscou comparar as duas IES, embora isso seja inevitável. O que se buscou objetivamente neste trabalho foi pesquisar, identificar e diagnosticar a CO existente no ambiente acadêmico de cada curso de Ciências Contábeis.

A primeira IES contatada foi a USP, em 25/02/2015, por meio de e-mails ao Coordenador do Curso, o qual facilitou o acesso ao departamento (EAC), fornecendo instruções sobre a melhor forma de contatar os professores e os discentes. Os primeiros seriam entrevistados e os segundos seriam submetidos à aplicação de um questionário por meio do aplicativo QuestionPro Survey Software, doravante denominado 'QuestionPro'. Também, entre 07 e 20/03/2015, foram feitas tentativas simultâneas por meio de e-mails e contatos telefônicos, com duas universidades estaduais públicas da Bahia: uma 'multicampi', distribuída em quase todo o Estado, porém sediada em Salvador, e a outra em Feira de Santana.

No dia 24/03/2015, a UEFS aceitou o convite, por meio de seu Pró-reitor de Administração e Finanças, o qual agradeceu, naquela ocasião, pela oportunidade de poder participar da pesquisa. Em seguida, facilitou o acesso, fornecendo telefones e e-mails da Coordenação do Colegiado do curso. Após contato com o coordenador, este também forneceu telefones e emails de docentes do curso, além de outras instruções e sugestões para o contato com os discentes. A outra IES, mesmo com novo convite em 23/03, não retornou.

Na USP, entre 26/02 e 04/03 de 2015, foram enviados e-mails de convite para entrevistas individuais a 15 docentes, que estivessem ligados às áreas de contabilidade societária, gerencial e/ou educação e pesquisa. Foram fornecidas informações e explicações sobre o trabalho, além da forma de realização da entrevista. Oito docentes rapidamente aceitaram participar e confirmaram datas, sendo que mais dois docentes confirmaram os seus horários no período em que o pesquisador já se encontrava na FEA, realizando as entrevistas.

Na UEFS, entre 06 e 10/04 de 2015, usando os mesmos critérios adotados na USP, enviouse e-mails de convite para 14 docentes, com informações e explicações sobre a pesquisa, além 
da forma de realização da entrevista. Oito docentes aceitaram participar e confirmaram datas, mas, por motivos supervenientes, três deles foram entrevistados fora do ambiente de trabalho, conforme apresentado na Tabela 17, na seção 3.4. Não há no portal do DCIS/UEFS as áreas nas quais os docentes atuam. A realização das entrevistas teve alguns imprevistos que duraram pouco mais de 15 dias entre o final de abril e o primeiro decêndio de maio de 2015, porém não de forma contínua, mas em ocasiões distintas devido a problemas de paralisação de vigilantes e, logo em seguida, à paralisação dos professores de todas as universidades estaduais da Bahia.

Com referência aos discentes da USP, foi elaborado um texto disponibilizado no dia 06/03/2015 pelo coordenador do curso, em um sistema auxiliar acadêmico de divulgação geral de informações para alunos e professores, convidando os alunos a participar da pesquisa de duas formas: i) respondendo a um survey eletrônico da 'QuestionPro' por meio de um link fornecido; e ii) oferecendo-se para participar de um grupo focal que seria realizado com, no máximo, dez alunos do período matutino e dez alunos do período noturno. Os brindes ofertados seriam: um livro de Manual de Contabilidade Societária da FIPECAFI, na sua edição mais recente, para o survey e dois livros (um para cada período) de 'Contabilidade Gerencial: Informação para tomada de decisão e execução da estratégia' de S. Mark Young, Robert S. Kaplan, Anthony A. Atkinson e Ella Mae Matsumura, em sua $4^{\text {a }}$ edição, de 2015.

Passados cinco dias, apenas dois alunos haviam respondido o questionário e nenhum havia se habilitado ao grupo focal. Assim, foi decidido revisar o texto anterior e trocar o brinde do Manual de Contabilidade Societária por um leitor de e-books Kindle Amazon Paperwhite. Esse novo texto foi disponibilizado no dia 11/03/2015 e depois de duas semanas, com apenas seis respondentes ao survey e nenhum voluntário para o grupo focal, foi decidido excluir essa dinâmica e mudar a estratégia de uso do levantamento para aplicá-lo em sala de aula. Graças à colaboração de docentes da FEA/USP, incluindo os que já haviam participado das entrevistas, foram obtidos $101^{13}$ respondentes, além de outros 21 que acessaram o questionário por via eletrônica, no período entre 06/03 e 16/04. O resultado final foi de 122 alunos respondentes, sendo 54 do quinto semestre, 44 do sétimo semestre, 18 do nono semestre e seis de outros

\footnotetext{
${ }^{13}$ Os docentes que colaboraram com o survey informaram aos alunos em sala de aula que estes só poderiam preencher o questionário caso estivessem participando do survey pela primeira vez, para evitar dupla contagem.
} 
semestres (não houve alunos abaixo do $4^{\circ}$ semestre). A maioria dos alunos (95) era do período noturno, e 27 do matutino.

Os dias, disciplinas e quantidade de alunos, nos quais foram aplicados os 101 questionários no curso da FEA/USP foram: 26/04 - Análise de Custos (EAC-314) - 25; $27 / 04$ - Auditoria e Perícia (EAC-401) - 12; 08/04 - Controladoria (EAC-512) - 32; e 09/04 - Ética Profissional (EAC510) - 32. Dos 101 alunos, 12 eram do turno matutino, 2 no dia 26/04 e 10 no dia 27/04.

Em vista da experiência obtida com os alunos do curso de Ciências Contábeis da USP, foi decidido utilizar a forma alternativa na UEFS, fazendo o survey diretamente com os alunos. Para tanto, este pesquisador, entre 27 e 29/04/2015, contou com a colaboração de docentes da UEFS e com a cooperação do coordenador do curso, indo de sala em sala. Foram explicados, sucintamente, a pesquisa, o questionário, seu objetivo e a importância para o trabalho. Ao final, foram 84 alunos respondentes, sendo 18 do quarto semestre, 18 do quinto, 15 do sexto, 10 do oitavo, cinco do sétimo e 18 de outros semestres. O curso de Ciências Contábeis da UEFS só é ofertado no período noturno.

Os dias, disciplinas e quantidade de alunos, nos quais foram aplicados os 84 questionários no curso do DCIS/UEFS, foram: 27/04 - Contabilidade Avançada (CIS446) - 15; 27/04 Direito Tributário (CIS459) - 18; 28/04 - Sociologia Geral das Organizações (CHS222) - 18; 28/04 - Jogos de Empresas (CIS603) - 15; e 29/04 - Consultoria Contábil Financeira $($ CIS495) -18 .

Um aspecto importante para a pesquisa empírica nas duas universidades citadas foi a realização do pré-teste da pesquisa na Universidade Católica de Salvador (UCSAL), entre os dias 20 e 24 de outubro de 2014. Naquela ocasião, seis professores foram entrevistados individualmente e cada entrevista foi gravada, com duração média de 60 minutos. As gravações foram transcritas e depois editadas e organizadas para se obter um Discurso do Sujeito Coletivo (DSC) dos docentes. Foram realizadas duas sessões de grupo focal, sendo a primeira com oito alunos e a segunda com doze.

Conseguiu-se ainda a participação de 38 alunos da UCSAL que responderam a um questionário com 16 questões fechadas, com cinco opções na escala do tipo Likert, elaborado 
e adaptado do modelo de pesquisa de Denison et al. (2012), visto na seção 2.3.2. Os resultados desse pré-teste propiciaram melhorias tanto na redação das questões quanto na forma de condução das entrevistas e demais procedimentos metodológicos da pesquisa, como a dinâmica de grupo focal (que terminou não se realizando devido às razões já descritas), além do survey e da pesquisa documental.

A respeito da definição de duas universidades públicas e do número de docentes para as entrevistas, é oportuna a experiência de Borg e Gall (1979), segundo os quais, em muitos projetos de pesquisa educacional, pequenas amostras são mais adequadas do que grandes amostras. São os casos dos estudos de interpretação de conteúdos discursivos, entrevistas em profundidade, e quando outras técnicas de medição demoradas são empregadas.

Os entrevistadores em pesquisa educacional geralmente tendem a incluir algumas questões altamente estruturadas em seu roteiro de entrevista, mas eles visam primeiro atingir um nível semiestruturado (Borg \& Gall, 1979). Nessa etapa, o entrevistador faz uma série de questões estruturadas e, em seguida, as reformula mais profundamente, usando perguntas abertas, a fim de obter informações mais amplas e completas. Os autores afirmam que esta forma de entrevista possui maior vantagem de obter um objetivo razoável, e ainda permitir uma compreensão mais profunda das opiniões dos entrevistados, além das razões por trás delas, do que seria possível caso a coleta fosse realizada por meio de um questionário enviado pelo correio.

\subsection{A técnica do Discurso do Sujeito Coletivo (DSC).}

Nesta pesquisa foi empregada a Técnica do DSC, a qual adota uma suposição de base socioantropológica, ancorada na Teoria das Representações Sociais (TRS), de que o pensamento de uma coletividade sobre um determinado tema pode ser visto como as representações sociais existentes da cultura daquele grupamento social sobre esse tema (Lefevre \& Lefevre, 2005).

Esse aspecto é socialmente possível na medida em que se entendam as formações sociais, em conformidade com a TRS, como entidades compostas por representações sociais sob a 
forma de discursos coletivos que os indivíduos passam a internalizar nas suas crenças e valores como sendo seus (Lefevre e Lefevre, 2012). A TRS, desenvolvida por Moscovici (1975), foi sistematizada por Jodelet (2001, p.5-6), sua principal colaboradora, a qual afirmou que existe uma primeira caracterização da representação social sobre a qual há concordância na comunidade científica.

É uma forma de conhecimento, socialmente elaborado e compartilhado, que tem um objetivo prático e concorre para a construção de uma realidade comum a um conjunto social. Igualmente designado como "saber do senso comum" ou ainda "saber ingênuo", "natural", esta forma de conhecimento distingue-se, dentre outras, do conhecimento científico. Mas ela é tida como um objeto de estudo tão legítimo quanto aquele, por sua importância na vida social, pelos esclarecimentos que traz acerca dos processos cognitivos e as interações sociais (Jodelet, 2001, p.5-6).

As representações sociais (RS) são, por consequência, modalidades de conhecimento que se manifestam como elementos cognitivos, tais como imagens, conceitos, categorias e teorias, porém não se reduzem a esses componentes cognitivos (Spink, 1993). Devido às suas relações com a linguagem, ideologia, imaginário social, e por seu papel na orientação de condutas e práticas sociais, as RS se constituem em elementos essenciais à análise dos mecanismos que interferem na eficácia do processo educativo (Alves-Mazzotti, 2008).

De acordo com Lefevre e Lefevre (2012), a técnica do DSC originou-se, no final da década de 1990, na Faculdade de Saúde Pública da Universidade de São Paulo, a partir de uma necessidade lógica: se, em qualquer grupo, comunidade ou sociedade, seus indivíduos compartilham ideias, opiniões, crenças ou representações, a expressão aglutinada dessas manifestações “[...] poderia comportar a reunião em discursos-síntese dos conteúdos e argumentos que conformam essas opiniões semelhantes” (Lefevre \& Lefevre, 2012, p. 17).

Em 2004, estes autores contrataram uma empresa de programação em tecnologia da informação para desenvolver um software, que recebeu a denominação Qualiquantisoft, contemplando o 'passo a passo' dessa técnica. De forma inovadora, os autores incorporaram o aspecto quantitativo em uma metodologia qualitativa, com o objetivo de mostrar o quanto as ideias se repetem entre os entrevistados.

O autor desta tese iniciou contato em 8 de junho de 2015 com um dos criadores da Técnica do DSC, Professor Fernando Lefevre. No dia seguinte, este aceitou o convite para auxiliar o 
autor no uso da técnica. Foi sugerido por ele o emprego do Qualiquantisoft, cuja licença de uso foi adquirida na primeira reunião de trabalho feita em SP. O professor interessou-se pela pesquisa, o que contribuiu tanto para a rápida e melhor assimilação da técnica quanto para a utilização do software. Ocorreram três reuniões no Instituto de Pesquisa do Discurso do Sujeito Coletivo (IPDSC), criado pelo professor Lefevre, nos dias 17/06, 22/07 e 19/08. Foram também realizados doze contatos telefônicos e trocados 56 e-mails, no período de 8/06 a $28 / 08 / 2015$.

Para o uso da Técnica do DSC, é preciso inicialmente tomar os depoimentos dos entrevistados como 'matéria-prima' para identificar os Operadores do DSC. Segundo Lefevre e Lefevre (2012), os Operadores do DSC são: a) as Expressões-Chave (ECH); as Ideias Centrais (IC); as Ancoragens (AC); e as Categorias, cujos significados estão descritos abaixo:

Expressões-chave (ECH) - são segmentos ou partes contínuas ou descontínuas do discurso, identificadas pelo pesquisador, que revelam a essência do conteúdo do depoimento. Ou seja, indicam como o entrevistado quis dizer alguma coisa;

Ideias Centrais (IC) - são expressões linguísticas, também identificadas pelo pesquisador, que revelam, da forma mais sintética possível, os sentidos de cada um dos depoimentos convertidos em ECH. Ou seja, as IC indicam o que o entrevistado quis dizer, enquanto as $\mathrm{ECH}$ indicam como isso foi dito;

Ancoragem (AC) - é a expressão de uma teoria ou ideologia embutida no discurso do entrevistado, porém dita como se fosse uma afirmação qualquer;

Categoria - é uma descrição sintética do sujeito coletivo que abrange duas ou mais IC.

As Categorias e Ancoragens servem para organizar os vários conteúdos dos discursos (ECH e IC), visando apresentá-los de forma mais didática e ordenada. O DSC é elaborado a partir da conexão das ideias centrais (IC) de cada Categoria, adicionando-se conectivos e outros recursos gramaticais para converter essas IC coletivas em uma só fala individual.

\subsection{Trabalho de campo}

As técnicas para coleta de informações e dados, bem como seu processamento e interpretação, usam uma triangulação de estratégias: entrevistas individuais em profundidade 
combinadas com questões semiestruturadas realizadas com os docentes; uso de questionário com os 206 alunos dos cursos de Ciências Contábeis (122 da FEA/USP e 84 do DCIS/UEFS); e uso da técnica do DSC no tratamento dos conteúdos discursivos dos docentes. Os procedimentos realizados na pesquisa estão dispostos em cinco etapas:

a) Pesquisa documental no campo empírico das IES escolhidas, visando levantar 'como', 'para que' e 'por quem' elas foram instituídas, as lideranças que se destacaram ao longo do tempo no curso de Ciências Contábeis, assim como eventos e outros registros que tenham merecido destaque na evolução histórica dessas IES até os dias atuais. Para a elaboração dessa pequena retrospectiva histórica, também foram consideradas as falas coletivas dos docentes, desde que os aspectos históricos das IES estivessem contemplados no seu escopo. Para auxílio na identificação, organização e elaboração de aspectos relevantes e objetivos dessa retrospectiva, foi realizada pesquisa documental em artigos, livros e portais das IES disponibilizados na internet, além de projetos político-pedagógicos dos seus cursos de Ciências Contábeis;

b) Entrevistas em profundidade com os docentes dos cursos, baseadas em uma combinação (bricolage $^{14}$ ) de elementos, por prioridade, da pesquisa clínica de Schein (2009), do modelo de pesquisa de Denison et al. (2012) e parte do roteiro de Hofstede (2012). As entrevistas duraram, em média, 58 minutos, divididas em duas etapas de igual duração, cujos detalhes estão descritos mais adiante;

c) A partir das informações coletadas nas entrevistas, posteriormente transcritas, foi utilizada a Técnica do DSC com o propósito de se obter uma fala única, porém representativa, da coletividade do grupo social docente dos cursos de cada IES. As características de realização das entrevistas estão descritas na Tabela 17.

Tabela 17

Informações sobre local, data, hora e duração das entrevistas (março-maio/2015)

\begin{tabular}{l|l|l|c|c|c}
\hline Entrevistado & IES & Local da entrevista & Dia/mês & Horário & $\begin{array}{c}\text { Duração } \\
\text { (minutos) }\end{array}$ \\
\hline Fea1 & USP & Sala do professor - FEA & $24 / \mathrm{mar}$ & $09: 00$ & 55 \\
\hline Fea2 & USP & Sala do professor - FEA & $24 / \mathrm{mar}$ & $11: 00$ & 56 \\
\hline Fea3 & USP & Sala do professor - FEA & $24 / \mathrm{mar}$ & $14: 00$ & 50 \\
\hline
\end{tabular}

${ }^{14}$ Bricolage ou do it yourself (faça você mesmo). Segundo Fleury (1996), a investigação é realizada pelo próprio pesquisador, que faz adaptações e/ou inovações com base nas técnicas existentes, sem o auxílio de um profissional. 
Continuação da Tabela 17

\begin{tabular}{|c|c|c|c|c|c|}
\hline Entrevistado & IES & Local da entrevista & Dia/mês & Horário & $\begin{array}{l}\text { Duração } \\
\text { (minutos) }\end{array}$ \\
\hline Fea4 & USP & Sala do professor - FEA & $25 / \mathrm{mar}$ & $10: 00$ & 54 \\
\hline Fea5 & USP & Sala do professor - FEA & $25 / \mathrm{mar}$ & $14: 00$ & 67 \\
\hline Fea6 & USP & Sala do professor - FEA & $26 / \mathrm{mar}$ & 09:00 & 50 \\
\hline Fea7 & USP & Sala do professor - FEA & $26 / \mathrm{mar}$ & $14: 00$ & 66 \\
\hline Fea8 & USP & Sala do professor - FEA & $27 / \mathrm{mar}$ & 09:00 & 58 \\
\hline Fea9 & USP & Sala do professor - FEA & $27 / \mathrm{mar}$ & $15: 00$ & 54 \\
\hline Fea10 & USP & Sala do professor - FEA & $30 /$ mar & $16: 00$ & 61 \\
\hline DCIS1 & UEFS & Secretaria de cursos - UEFS & $13 / \mathrm{abr}$ & $14: 00$ & 55 \\
\hline DCIS2 & UEFS & Sala do professor - DCIS & $28 / \mathrm{abr}$ & $18: 00$ & 70 \\
\hline DCIS3 & UEFS & Sala de aula (vazia) - DCIS & $29 / \mathrm{abr}$ & $16: 00$ & 56 \\
\hline DCIS4 & UEFS & Sala dos professores - DCIS & $30 / a b r$ & $18: 30$ & 50 \\
\hline DCIS5 & UEFS & Laboratório de informática - DCIS & $30 / a b r$ & $22: 00$ & 52 \\
\hline DCIS6 & UEFS & UCSAL - Campus Federação (sala) & 06/mai & $15: 00$ & 58 \\
\hline DCIS7 & UEFS & Livraria Cultura - Salvador Shopping & 07/mai & $15: 00$ & 65 \\
\hline DCIS8 & UEFS & UCSAL - Campus Pituassu (Secretaria) & 08/mai & $14: 00$ & 63 \\
\hline
\end{tabular}

d) Os resultados do pré-teste na UCSAL propiciaram o aperfeiçoamento do questionário, que passou a contar com 22 perguntas fechadas, das quais 17 sobre o tema da pesquisa, sendo uma criada durante o aperfeiçoamento deste trabalho, 16 elaboradas e adaptadas com base em Denison et al. (2012), e depois aprimoradas com o pré-teste, e mais cinco questões, também criadas durante o desenvolvimento do trabalho para caracterização do aluno respondente. Das 17 questões, 16 tinham cinco opções, usando a escala do tipo Likert. O principal propósito do questionário foi contribuir para a triangulação de estratégias, visando fortalecer os achados, ao confrontar a percepção dos alunos com os resultados obtidos do estudo qualitativo com os docentes; e

e) Aplicação de um survey na amostra obtida de 206 alunos, sendo 122 da FEA/USP e 84 do DCIS/UEFS, cuja forma de acesso está explicitada na seção 3.2. O survey abrange 22 afirmações/questões adaptadas para sua aplicação nas IES. Das 22 questões, 16 são baseadas nas quatro dimensões desenvolvidas por Denison et al. (2012): missão; adaptabilidade externa, integração interna; e consistência. Entretanto, maior ênfase foi dada às duas dimensões tidas por Schein (2009) como as que contêm os dois problemas fundamentais que as culturas das organizações precisam resolver ao mesmo tempo: adaptabilidade externa e integração interna. 
As 18 entrevistas consumiram 17 horas e 20 minutos. Na primeira etapa de cada uma, foi formulada para cada docente a questão da pesquisa: qual a sua percepção sobre o atual estágio da COA da sua IES relativa ao curso de Ciências Contábeis, nas dimensões: i) missão; ii) adaptabilidade externa; iii) integração interna (ou envolvimento); e iv) consistência.

Antes da entrevista, os docentes foram informados sobre os objetivos e os principais conceitos ligados à cultura organizacional e como seria realizada a entrevista. Estas informações já haviam sido previamente fornecidas por e-mail quando do contato inicial, mas foram reforçadas, além do esclarecimento de dúvidas. Assim, na primeira parte da entrevista, os docentes deveriam responder, a princípio, de forma livre, narrativa e sem interrupções, destacando aspectos considerados relevantes sobre a retrospectiva da COA. Contudo, houve casos em que os docentes responderam de forma muito breve, exigindo que o entrevistador fizesse indagações sobre certos aspectos que não haviam sido entendidos adequadamente.

$\mathrm{Na}$ segunda etapa, o entrevistador usou a parte semiestruturada do procedimento, utilizando as 16 questões baseadas nas afirmações do survey, constantes na Tabela 19 (mais adiante), como um roteiro-guia. As perguntas eram feitas segundo o exemplo: qual a sua opinião ou como você avalia que 'as ações da gestão indicam que ela segue a missão'? As respostas foram usadas para complementar/enriquecer a primeira etapa. Nesse segundo momento, já estava previsto que o entrevistador, diante das respostas, fizesse indagações sucessivas com o objetivo de obter um depoimento mais amplo, propiciando a oportunidade de aparecer aspectos aparentemente ocultos numa visão superficial.

As entrevistas foram gravadas, e depois efetuado backup de cada uma por medida de segurança. Cada gravação foi transcrita, editada e depois organizada em duas etapas. A primeira etapa contém os seguintes passos:

i. identificação e eliminação do que Lefevre e Lefevre (2012) denominam 'lixo discursivo', que são aspectos muito particularizados e pessoais do entrevistado que não possuem relação com a questão de pesquisa;

ii. adaptação e enquadramento dos conteúdos à questão da pesquisa, desdobrada nas suas quatro dimensões (missão, adaptabilidade externa, integração interna e consistência); e 
iii. identificação de aspectos comuns mencionados nas entrevistas, que não estivessem ligados fundamentalmente ao problema da pesquisa, mas que pudessem ser aproveitados para apresentar uma retrospectiva histórica dos cursos na visão coletiva dos docentes de cada IES.

A segunda etapa foi subdividida nos seguintes estágios:

i. ajuste final nos depoimentos individuais relativos a cada dimensão da questão de pesquisa, por universidade;

ii. identificação das expressões-chave $(\mathrm{ECH})$. Cada dimensão tem uma ECH (4 dimensões x 10 entrevistados = 40 ECH na FEA; e 4 x 8 entrevistados $=32$ ECH na UEFS);

iii. sintetização das ECH. Foram identificadas e editadas de uma a duas ideias centrais (IC) por docente e IES. No total resultaram 55 IC na FEA e 57 IC na UEFS (ver Tabela 18);

iv. classificação das IC em categorias por IES, ficando 14 categorias na FEA e 12 na UEFS, totalizando 26 categorias (ver Tabela 18); e

v. identificação, nas IC de cada categoria, de duplicidades de falas; depois elas foram agrupadas, sintetizadas, adequadas, e compuseram um DSC único para cada categoria.

$\mathrm{O}$ autor deste trabalho buscou continuamente ser imparcial e vigilante na transcrição, edição, adequação e elaboração dos DSC com o propósito de que estes pudessem representar, fidedignamente, o pensamento coletivo dos docentes. As inferências e/ou interpretações do autor, quando realizadas nos capítulos seguinte e posterior, restringiram-se às informações e dados coletados, assim como as deduções sobre o comportamento dos sujeitos da pesquisa.

Para maior compreensão da segunda etapa, principalmente quanto aos itens (iii) e (iv), a Tabela 18 apresenta as quatro dimensões abordadas e seus respectivos desdobramentos em Categorias e Ideias Centrais (IC). O DSC é elaborado a partir das IC contidas em cada Categoria.

É possível perceber, pelo objetivo comum da pesquisa empírica, que os nomes das categorias tendem a ficar equivalentes na maioria das situações nas duas IES. Por exemplo, na dimensão 'missão', as categorias utilizadas foram basicamente as mesmas para cada IES. Na 'Integração interna', também, houve grande similaridade. 
Tabela 18

Dimensões da COA, Categorias e quantidade de IC

\begin{tabular}{|c|c|c|c|c|}
\hline \multirow{2}{*}{ Dimensões da COA } & \multicolumn{4}{|c|}{ Categorias (descrição definida) } \\
\hline & FEA/USP & IC & DCIS/UEFS & IC \\
\hline Missão & $\begin{array}{l}\text { Missão } \\
\text { COA e Gestão } \\
\text { Curso de Ciências Contábeis }\end{array}$ & $\begin{array}{l}6 \\
4 \\
4 \\
\end{array}$ & $\begin{array}{l}\text { Missão } \\
\text { Gestão } \\
\text { Curso de Ciências Contábeis } \\
\end{array}$ & $\begin{array}{l}7 \\
6 \\
3\end{array}$ \\
\hline Adaptabilidade externa & $\begin{array}{l}\text { Internacionalização } \\
\text { Mudanças na universidade } \\
\text { Ensino-aprendizagem }\end{array}$ & $\begin{array}{l}6 \\
1 \\
3 \\
\end{array}$ & $\begin{array}{l}\text { Ações frente às mudanças } \\
\text { COA do curso na UEFS } \\
\text { Ensino-aprendizagem }\end{array}$ & $\begin{array}{l}7 \\
4 \\
2\end{array}$ \\
\hline Integração interna & $\begin{array}{l}\text { Ensino-aprendizagem } \\
\text { COA do curso } \\
\text { Liderança } \\
\text { Integração }\end{array}$ & $\begin{array}{l}5 \\
4 \\
4 \\
3\end{array}$ & $\begin{array}{l}\text { Ensino-aprendizagem } \\
\text { Engajamento docente } \\
\text { Liderança e gestão }\end{array}$ & $\begin{array}{l}7 \\
3 \\
3\end{array}$ \\
\hline Consistência & $\begin{array}{l}\text { Curso de Ciências Contábeis } \\
\text { FEA/USP como universidade } \\
\text { COA da FEA/USP } \\
\text { Engajamento e integração }\end{array}$ & $\begin{array}{l}4 \\
4 \\
4 \\
3 \\
\end{array}$ & $\begin{array}{l}\text { COA do Curso na UEFS } \\
\text { Curso de Ciências Contábeis } \\
\text { Integração e gestão }\end{array}$ & $\begin{array}{l}6 \\
4 \\
5\end{array}$ \\
\hline Total & 14 & 55 & 12 & 57 \\
\hline
\end{tabular}

Portanto, ligados à questão da pesquisa, no caso da FEA, de 55 IC foram elaborados 14 DSC, sendo três em cada uma das duas primeiras dimensões, e quatro em cada uma das duas últimas dimensões. No caso da UEFS, de 57 IC foram elaborados 12 DSC, sendo três para cada uma das quatro dimensões, perfazendo 26 DSC para as duas IES. A partir dos depoimentos dos docentes que faziam alusão a aspectos históricos, foi possível obter mais dois DSC, um para cada IES. Finalmente, dos 26 DSC ligados à pesquisa, foram retirados trechos comuns às duas IES, que se constituiu em um DSC derivado, porém este ficou restrito apenas a aspectos críticos. Infelizmente, não foi possível obter um DSC comum às IES que tratasse de aspectos positivos.

O Qualiquantisoft funciona como um repositório de dados: faz-se o cadastro da pesquisa, dos entrevistados por IES e das ECH. Depois há um procedimento que faz uma cópia de cada $\mathrm{ECH}$ e, a partir dessa cópia, são identificadas e editadas as IC e, eventualmente, as Ancoragens. Em seguida há a etapa de classificação das IC em Categorias, as quais contêm, cada uma, suas respectivas IC. Só a partir dessa penúltima etapa é que a fase final de construção (edição) dos DSC é iniciada, com a aglutinação ou fusão de frases com o mesmo sentido, destaques para IC antagônicas, aprimoramento de IC que possuem ideias distintas, 
tanto críticas quanto positivas. Conforme citado na seção 3.3, para a elaboração de cada DSC, que equivale à fala de um sujeito representando a coletividade, são usados conectivos e outros recursos gramaticais.

Finalmente, com relação ao survey, é oportuno frisar: o objetivo fundamental de sua aplicação, junto aos alunos do curso de Ciências Contábeis de ambas as IES, foi confrontar os resultados obtidos com a percepção coletiva dos docentes, para obter uma visão conjunta desses atores. O questionário para o survey está apresentado na Tabela 19.

Tabela 19

Questionário para o survey com os alunos do curso de Ciências Contábeis das IES

\begin{tabular}{|c|c|c|c|c|c|}
\hline \multirow{2}{*}{ DESCRIÇÃO } & \multicolumn{2}{|c|}{ Discordo } & \multirow{2}{*}{$\begin{array}{l}\text { Nem } \\
\text { discordo } \\
\text { nem } \\
\text { concordo }\end{array}$} & \multicolumn{2}{|c|}{ Concordo } \\
\hline & $\begin{array}{l}\text { Total- } \\
\text { mente }\end{array}$ & $\begin{array}{l}\text { Parcial } \\
\text {-mente }\end{array}$ & & $\begin{array}{l}\text { Parcial- } \\
\text { mente }\end{array}$ & $\begin{array}{l}\text { Total- } \\
\text { mente }\end{array}$ \\
\hline \multicolumn{6}{|l|}{$\begin{array}{l}\text { Dimensão - a) Missão } \\
\text { 1) As ações da gestão do curso indicam que ela segue a } \\
\text { missão }\end{array}$} \\
\hline \multicolumn{6}{|l|}{$\begin{array}{l}\text { 2) A coordenação controla metas e objetivos durante o } \\
\text { curso visando assegurar o seu sucesso }\end{array}$} \\
\hline \multicolumn{6}{|l|}{$\begin{array}{l}\text { 3) As metodologias dos docentes são adequadas aos } \\
\text { objetivos do curso e da IES }\end{array}$} \\
\hline \multicolumn{6}{|l|}{$\begin{array}{l}\text { 4) As práticas docentes são adequadas ao que se espera } \\
\text { do contador no futuro }\end{array}$} \\
\hline \multicolumn{6}{|l|}{$\begin{array}{l}\text { Dimensão: b) Adaptabilidade externa } \\
\text { 5) De acordo com os desempenhos obtidos no Enade } \\
\text { e/ou no Exame do CFC, a gestão promove mudanças } \\
\text { no curso }\end{array}$} \\
\hline \multicolumn{6}{|l|}{$\begin{array}{l}\text { 6) Os docentes trazem temas práticos do mercado } \\
\text { profissional para a sala de aula }\end{array}$} \\
\hline \multicolumn{6}{|l|}{$\begin{array}{l}\text { 7) Os docentes procuram atualizar os alunos com a } \\
\text { realidade do mercado profissional }\end{array}$} \\
\hline \multicolumn{6}{|l|}{$\begin{array}{l}\text { 8) Percebo que os docentes procuram se integrar com } \\
\text { os alunos na melhoria no ensino-aprendizagem }\end{array}$} \\
\hline \multicolumn{6}{|l|}{$\begin{array}{l}\text { Dimensão: c) Integração Interna } \\
\text { 9) Os alunos dispõem de informações suficientes para } \\
\text { o bom andamento do curso }\end{array}$} \\
\hline \multicolumn{6}{|l|}{$\begin{array}{l}\text { 10) Percebo que há integração entre a coordenação e } \\
\text { os docentes do curso }\end{array}$} \\
\hline \multicolumn{6}{|l|}{$\begin{array}{l}\text { 11) Percebo que existe uma cultura acadêmica } \\
\text { específica da IES quanto ao curso de Ciências } \\
\text { Contábeis }\end{array}$} \\
\hline $\begin{array}{l}\text { 12) Eu me sinto motivado para o aprendizado pelos } \\
\text { docentes }\end{array}$ & & & & & \\
\hline
\end{tabular}


Continuação da Tabela 19

\begin{tabular}{l|c|c|c|c|c}
\hline \multicolumn{1}{c|}{ DESCRIÇÃo } & \multicolumn{2}{c|}{ Discordo } & $\begin{array}{c}\text { Nem } \\
\text { discordo } \\
\text { nem }\end{array}$ & \multicolumn{2}{c}{ Concordo } \\
\cline { 2 - 5 } & & $\begin{array}{c}\text { Total- } \\
\text { mente }\end{array}$ & $\begin{array}{c}\text { Total- } \\
\text { mente }\end{array}$ & $\begin{array}{c}\text { Parcial- } \\
\text { mente }\end{array}$ & $\begin{array}{c}\text { Total- } \\
\text { mente }\end{array}$ \\
\hline $\begin{array}{l}\text { Dimensão: d) Consistência da Cultura } \\
\text { 13) As promessas feitas pela coordenação do curso são } \\
\text { cumpridas através das práticas dos docentes no ensino- } \\
\text { aprendizagem }\end{array}$ & & & & \\
\hline $\begin{array}{l}\text { 14) A cultura (costumes, crenças e valores) do } \\
\text { curso/IES indicam seu compromisso com o curso de }\end{array}$ & & & & \\
Ciências Contábeis & & & & \\
\hline $\begin{array}{l}\text { 15) As práticas dos docentes indicam que eles estão } \\
\text { integrados com o curso }\end{array}$ & & & & \\
\hline $\begin{array}{l}\text { 16) Pela integração entre a coordenação e docentes do } \\
\text { curso, eu percebo a existência de sólida liderança no } \\
\text { curso/IES }\end{array}$ & & & & & \\
\hline
\end{tabular}

17) Questão (nesta questão você pode marcar mais de uma opção)

O que deve ser mudado no curso para que ele se torne tão atual quanto o dinâmico mercado profissional?

( ) Atualização dinâmica da grade curricular. ( ) Incentivo maior à pesquisa.

( ) Os docentes deveriam trabalhar mais com problemas e estudos de caso.

( ) O curso deveria fazer mais eventos com pessoas ou empresas do mercado profissional.

( ) O curso deveria ter uma prática tão intensa quanto a teoria.

18) Semestre? ( ) 19) Sexo: ( ) Masc. ( ) Fem. 20) Turno: ( ) Mat. ( ) Not.

21) Você trabalha ou só estuda? ( ) Trabalho em tempo integral （） Trabalho em tempo parcial

( ) Faço estágio em tempo integral ( ) Faço estágio em tempo parcial ( ) Apenas estudo

22) Faixa etária? $\quad(\quad) 16-20 \quad(\quad$ ) 21-25 $) \quad(26-30) \quad(31-35) \quad(\quad) 36$ em diante




\section{RESULTADOS}

O objetivo deste capítulo é apresentar os resultados do estudo, bem como sua análise, a partir das respostas à questão de pesquisa. $\mathrm{O}$ capítulo está subdividido em três seções: nas duas primeiras são apresentados os resultados dos levantamentos e entrevistas efetuados nos cursos de Ciências Contábeis da FEA/USP e do DCIS/UEFS. Na terceira seção são mostrados os elementos comuns entre as duas IES em relação à COA.

\subsection{Curso de Ciências Contábeis da FEA/USP}

Esta seção subdivide-se em 4 subseções: i) a primeira contém um breve histórico da USP, da FEA e do curso, a partir de documentos internos e externos; ii) a segunda apresenta os resultados das entrevistas com os docentes, começando com uma retrospectiva histórica do curso na visão dos docentes entrevistados; iii) a terceira apresenta os resultados do levantamento feito com os 122 alunos do curso; e iv) a quarta apresenta uma síntese, confrontando os resultados dos docentes e dos alunos, e algumas conclusões.

\subsubsection{Breve histórico do curso de Ciências Contábeis da FEA/USP}

Motoyama, Souza, Rocha e Santos (2011) mencionam que a Universidade de São Paulo [USP] surgiu graças ao empenho da denominada 'Comunhão Paulista', considerada como uma das representantes da elite paulista no seu segmento mais intelectualizado. Sobre a constituição da USP, os autores acrescentam:

Do ponto de vista mais amplo, resultou do esforço de modernização promovido desde os meados do século XIX pelos fazendeiros de café do estado de São Paulo, imbuídos de uma mentalidade mais capitalista e burguesa. Na sua concretização, pesou muito a ocorrência da Revolução de 1930 e da Revolução Constitucionalista de 1932 (Motoyama et al., 2011, p. 13).

De acordo com Souza Campos (2004), após muitas tentativas ao longo de décadas, a Universidade de São Paulo finalmente foi criada pelo Decreto $n^{\circ} 6.285$ de 25 de janeiro de 1934, pelo então governador do Estado Armando de Salles Oliveira, considerado como o fundador da USP. A citação seguinte refere-se à ocasião. 
Finalmente, depois de tantos anseios, de tão vigorosa propaganda, concretizava-se a idéia pela conjugação, sob a égide de uma unidade universitária comum, das grandes e prestigiosas instituições de ensino superior existentes em São Paulo, acrescidas de duas faculdades remodeladas e de uma nova, fundamental, a Faculdade de Filosofia, Ciências e Letras, laço de entrosamento científico-cultural pelas secções numerosas e variadas (Souza Campos, 2004, p. 100).

O primeiro reitor da USP foi o professor Reynaldo Porchat. Segundo Souza Campos (2004), consta no referido decreto de constituição da USP que esta abrangia os seguintes institutos oficiais: a) a Faculdade de Direito; a Faculdade de Medicina; c) a Faculdade de Farmácia e Odontologia; d) a Escola Politécnica; e) o Instituto de Educação; f) a Faculdade de Filosofia, Ciências e Letras; g) o Instituto de Ciências Econômicas e Comerciais; h) a Escola de Medicina Veterinária; i) a Escola Superior de Agricultura; e j) a Escola de Belas Artes.

Além das instituições relacionadas anteriormente, Souza Campos (2004) complementa que o citado decreto relaciona outras unidades que concorreram para ampliar o ensino e a ação da Universidade de São Paulo: a) o Instituto Biológico; b) o Instituto de Higiene; c) o Instituto Butantã; d) o Instituto Agronômico de Campinas; e) o Instituto Astronômico e Geofísico; f) o Instituto de Radium "Dr. Arnaldo Vieira de Carvalho"; g) a Assistência Social a Psicopatas; h) o Instituto de Pesquisas Tecnológicas; i) o Museu de Arqueologia, História e Etnografia (Museu Paulista); j) o Serviço Florestal; e k) e quaisquer outras instituições de caráter técnico e científico do Estado.

Em junho de 1935, o então governador do Estado constituiu uma comissão que ficou encarregada de estudar o problema de localização da Cidade Universitária. A comissão foi presidida pelo então reitor professor Reynaldo Porchat e os demais membros eram os professores Fernando de Azevedo, Alexandre de Albuquerque, Ernesto Leme, Afrânio do Amaral, Mário de Andrade e Ernesto de Souza Campos, autor da obra de onde foram extraídas essas informações. Souza Campos (2004) afirma que, após várias reuniões realizadas entre os meses de junho, julho e agosto de 1935, a comissão, por decisão unânime, escolheu a área de terreno compreendida entre a Faculdade de Medicina e o Butantã.

De acordo com USP (2015a), em 2014 a universidade teve uma produção científica de 21.248 itens, sendo 12.217 no Brasil e 9.031 no exterior. Desse total, 38,7\% eram artigos de periódicos, 26,3\% trabalhos apresentados em congressos e publicados, 20\% artigos em 
publicação e o restante distribuído em outros itens. Naquele ano a USP possuía 222 programas, com 353 mestrados e 323 doutorados, cobrindo 676 áreas de concentração. No total, 30.039 pós-graduandos estudavam nesses cursos, sendo $47 \%$ de mestrandos e $53 \%$ de doutorandos, vindos de todo o país.

Castro e Leite (2006) comentam que, na criação da USP, foram 'importados' renomados acadêmicos franceses, alemães e italianos. Consta no portal da USP (USP, 2015a):

A USP está na $29^{a}$ colocação no Webometrics Ranking of World Universities 2014, que considera os conteúdos disponibilizados na internet, especialmente aqueles relacionados a processos de geração e comunicação acadêmica de conhecimento científico. A Universidade está em $1^{\circ}$ lugar também no ranking Webometrics que avalia somente as universidades da América Latina, e no que classifica os países dos BRICS (Brasil, Rússia, Índia, China e África do Sul).

A USP também está bem posicionada em outros rankings internacionais. Em nível nacional ela repetidamente vem obtendo o $1^{\circ}$ lugar no Ranking Universitário Folha (RUF) do jornal Folha de São Paulo, que a classificou entre 192 universidades brasileiras em 2014, com base em indicadores que abrangem pesquisa, inserção no mercado de trabalho, ensino, inovação e internacionalização da Instituição de Ensino Superior (IES).

Para desenvolver todas as suas atividades, a USP conta atualmente com diversos campi, distribuídos pelas cidades de São Paulo, Bauru, Lorena, Piracicaba, Pirassununga, Ribeirão Preto, Santos e São Carlos. A USP possui ainda outras Unidades de Ensino, Museus e Centros de Pesquisa, situados fora desses espaços e em diferentes municípios.

A FEA/USP foi criada em 1946 com o nome de Faculdade de Ciências Econômicas e Administrativas (FCEA). No início, havia apenas dois cursos: o de Ciências Econômicas e o de Ciências Contábeis e Atuariais. Em 1964, uma reforma estrutural interna resultou na oferta de cinco graduações distintas: Ciências Econômicas, Ciências Contábeis, Ciências Atuariais, Administração de Empresas e Administração Pública. Em 1969, a USP promoveu outra reforma estrutural, alterando o nome de FCEA para FEA e surgindo a divisão dos departamentos em Economia, Administração e Contabilidade. 
Em 1990, foi nomeada oficialmente Faculdade de Economia, Administração e Contabilidade (FEA/USP, 2015b). Em 1992 foi fundada a extensão da FEA/USP na cidade de Ribeirão Preto, que passou a ofertar os cursos de Economia, Administração de Empresas e Contabilidade. Em 2002, esta Unidade deixou de ser subordinada à direção da FEA da capital e passou a ter autonomia administrativa.

Atualmente são quatro os cursos de graduação da FEA/USP: Administração de Empresas, Ciências Econômicas, Ciências Contábeis e Ciências Atuariais. Este último é ofertado somente no período noturno e os outros, nos períodos matutino e noturno. A Faculdade também oferece os cursos de mestrado e doutorado em Economia, implantados em 1966. Os de Administração e Ciências Contábeis foram implantados em 1970, sendo que o último recebeu a denominação de 'Controladoria e Contabilidade' (o mestrado teve início em 1970 e o doutorado passou a ser ofertado em 1978).

O curso de Bacharelado em Ciências Contábeis, vinculado às Ciências Atuariais, foi criado em 22 de setembro de 1945, por meio do Decreto-Lei $n^{0} 7.988$. Com a Lei ${ }^{\circ} 1.401$ de 31 de julho de 1951, os cursos de Ciências Contábeis e Ciências Atuariais foram desdobrados em dois cursos distintos (FEA/USP, 2015a). Pelos documentos formais da FEA/USP (2015b), a missão, visão e valores dos cursos de Ciências Contábeis e Ciências Atuariais são únicos para os dois cursos e são apresentados a seguir:

a) Missão: Proporcionar formação de excelência para desenvolver e capacitar líderes inovadores com potencial de transformação e atuação regional e global nas áreas de Ciências Contábeis e Atuariais.

b) Visão: Fortalecer-se como centro de referência em educação nas áreas de Ciências Contábeis e Atuariais na América Latina, com ações de impacto global.

c) Valores: Comprometimento acadêmico e profissional com as áreas de atuação e as organizações por meio de: i) Integração entre Ensino, Pesquisa e Extensão; ii) Responsabilidade Social e Sustentabilidade; iii) Integridade e Comportamento Ético; iv) Meritocracia e Reconhecimento de Talentos; v) Pluralismo e Diversidade; e vi) Inovação e Criatividade. 
No primeiro semestre de 2015, o curso de Ciências Contábeis contava com 663 alunos ativos, dos quais 218 no período matutino e 445 no período noturno. Havia no Departamento de Contabilidade e Atuária (EAC), no segundo semestre de 2015, 41 docentes, sendo seis titulares, cinco livres-docentes, 29 doutores e um assistente (FEA/USP, 2015c). Destes, 26 trabalham sob o Regime de Dedicação Integral à Docência e à Pesquisa (RDIDP), 10 sob o Regime de Turno Completo (RTC) e cinco sob o Regime de Turno Parcial (RTP) ${ }^{15}$.

\subsubsection{Resultado das entrevistas com os docentes da FEA/USP}

Nesta subseção são apresentados os resultados das entrevistas em profundidade com os dez docentes que, voluntariamente, aceitaram participar da pesquisa. Por motivo de confidencialidade, seus nomes foram omitidos.

Nos ambientes em que funciona o Departamento de Ciências Contábeis e Atuariais, foi possível observar o que Schein (2009) denomina artefatos (abrangem as estruturas e processos operacionais visíveis da organização), como os aspectos físicos externos e internos dos vários lugares, salas e prédios. Abrange ainda o relacionamento com muitas pessoas no 'dia a dia', como docentes do curso, técnicos, docentes e pessoas de fora da IES, inclusive do exterior.

Também foi possível ter proximidade com professores e alunos no cotidiano do curso, em duas disciplinas de graduação: Análise de Custos (primeiro semestre de 2013) e Relato Integrado (segundo semestre de 2013). Esta inserção se deu por meio das disciplinas obrigatórias do doutorado - Monitoria Didática I e II -, em que o doutorando auxilia o docente em algumas tarefas, tais como contribuir para a seleção das questões de provas e a sua correção.

Conforme descrito na seção 3.4, foi elaborado um DSC pelo autor, baseado nas entrevistas dos docentes, sobre a retrospectiva histórica do curso de Ciências Contábeis da FEA/USP.

\footnotetext{
${ }^{15}$ Segundo a USP (2015b), o RDIDP deve ter dedicação exclusiva à USP e só pode ter vinculação a ela. No RTC, o docente deve trabalhar na USP por 24 horas semanais, em atividades de ensino, pesquisa e extensão de serviços à comunidade. Esses dois regimes são considerados como especiais. No RTP, o docente deve trabalhar na USP por 12 horas semanais apenas em atividades de ensino.
} 
Criado em 1946, o Departamento de Contabilidade e Atuária da FEA evoluiu significativamente, tornando-se a maior referência em Contabilidade no Brasil, mormente devido ao carisma, compromisso e contribuições de alguns docentes, hoje ícones da área no país, tanto sob o ponto de vista acadêmico quanto profissional, para a academia e a sociedade, além de ter sido pioneiro na implantação de cursos stricto sensu desde 1970 (mestrado e doutorado).

Podemos afirmar que a cultura organizacional acadêmica (COA) do curso foi baseada no grande desenvolvimento da Contabilidade propiciada por esses ícones consagrados, como Francisco D’Áuria, Sérgio de Iudícibus, Eliseu Martins, Armando Catelli, Stephen Kanitz, Masayuki Nakagawa e José Carlos Marion, entre outros. A maioria dos atuais docentes do departamento se espelhou muito nas ideias, saberes e comportamentos desses ícones.

Nosso curso, consequentemente, tem sido sempre referido como o melhor do Brasil, e o nosso doutorado reinou sozinho no país durante quase 30 anos. No início não havia maiores preocupações quanto a mudanças, e até meados dos anos 1990, a nossa cultura acadêmica, envolvendo atividades de pesquisa e produção científica, possuía forte embasamento teórico-conceitual, com equilíbrio de usos dos métodos qualitativo e quantitativo, mas atualmente tem ocorrido o inverso, ou seja, a maioria das atividades de produção científica tem utilizado fortemente métodos quantitativos, em detrimento de métodos qualitativos, e com um referencial conceitual-teórico mais sintético.

O surgimento de outros centros de estudo com seus cursos stricto sensu e a ampliação do leque de objetivos da área contábil propiciaram a abertura de novas opções e desafios para o departamento, que aumentou o rigor na seleção de docentes (doutores) e o uso de instrumental sofisticado de métodos quantitativos nas suas produções científicas, seguindo a linha de congressos e periódicos internacionais, visando manter sua liderança.

A partir de meados da década de 1990, houve um pequeno decréscimo na nossa COA, mas, nos últimos 10 anos, temos observado que esta vem se aperfeiçoando continuamente, com relevantes mudanças dirigidas ao ambiente internacional. $\mathrm{O}$ ingresso de novos docentes com vivência global provocou uma retomada do crescimento da FEA que, com a meta de internacionalização da nova gestão, a partir de 2011, liderada pelo professor Edgard Cornachione, redefiniu e atualizou a missão do departamento, resultando na obtenção de projetos como o 'Discovery', com a Universidade de Illinois, e outros convênios com universidades no exterior, com o objetivo de realizar intercâmbios de docentes e alunos, além de reconhecimento e credenciamentos internacionais.

Nossa preocupação agora é que os novos docentes, mesmo com dificuldades, venham a dar continuidade a esse prestígio da cultura acadêmica contábil, desenvolvido pelos antigos docentes-ícones, e conduzir o aperfeiçoamento da escola no atual contexto em que está inserida, nos âmbitos nacional e internacional. Temos o dever de dar continuidade a esse nível de qualidade, que agora não visa apenas o contexto do Brasil e da América Latina, mas do mundo. 
Percebe-se, nesse DSC, além da evolução coerente, que a descrição parece vir apenas de uma fonte (na primeira pessoa do plural), além do nível de profundidade do conteúdo - tal como as suposições básicas de Schein (2009), apresentadas na seção 2.3.1, e o seu equivalente, valores, de acordo com Hofstede (2003), na seção 2.3.3 -, revistos mais adiante.

Pelo entendimento dos três níveis de cultura na teoria de Schein (2009), o DSC vai além do primeiro nível, que é o de artefatos, mencionado no início desta seção. O segundo nível de cultura compreende as crenças e valores expostos, que são representações do comportamento dos membros da organização em situações de decisão, os quais podem ser deduzidos, preliminarmente, dos DSC vinculados às respectivas categorias de cada dimensão, apresentadas mais adiante. $O$ terceiro nível é o de suposições básicas (ou a essência da cultura), que são as bases fundamentais dos sistemas de significados ou mecanismos de defesa cognitivos e psicológicos que permitem ao grupo continuar a funcionar.

Como muitas das respostas dos depoentes foram obtidas mediante sucessivas indagações do tipo 'por que', é muito provável que as associações de ideias decorrentes, expostas nos DSC, contenham aspectos do inconsciente coletivo dos docentes. Portanto, elas vão um pouco além desse nível de crenças e valores expostos, ou seja, elas representam o terceiro nível de cultura de Schein (2009), que é o de suposições básicas.

As suposições básicas representam a fala do inconsciente coletivo dos docentes (entrevistados) do curso de Ciências Contábeis da FEA, o que não seria possível por intermédio de instrumentos de pesquisa que resultassem em observações pontuais, como o diagnóstico de clima organizacional, segundo menciona Fleury (1996) na seção 3.1. O equivalente dessas suposições básicas na teoria de Hofstede (2003) é chamado de valores, situando-se no núcleo da cultura, cuja maior parte é inconsciente, não perceptível do exterior pelo pesquisador. Os valores podem ser entendidos como uma "tendência para se preferir certo estado de coisas em face de outro" (Hofstede, 2003, p. 23). Assim, os valores possuem um lado positivo e outro negativo, como por exemplo: bom e mau; limpo e sujo; normal e anormal, entre outros.

Com base nas respostas dos docentes à questão da pesquisa, desdobrada nas dimensões missão, adaptabilidade externa, integração interna e consistência, foram elaboradas quatro 
tabelas, uma para cada dimensão citada, contendo os DSC de cada dimensão, subdivididos em suas respectivas categorias. A dimensão missão está na Tabela 20.

Tabela 20

\section{DSC dos docentes da FEA/USP quanto à missão}

\begin{tabular}{|c|c|}
\hline Categorias & Discurso do Sujeito Coletivo (DSC) \\
\hline & $\begin{array}{l}\text { A missão original era atender a demanda existente, } \\
\text { que era interna. Com o tempo a FEA se expandiu e } \\
\text { passou a explorar caminhos internacionais. Ou seja, } \\
\text { a missão anterior era ofertar a melhor formação em } \\
\text { Contábeis no Brasil e América Latina, e a atual foi } \\
\text { ampliada para um contexto global. }\end{array}$ \\
\hline
\end{tabular}

Missão: O sujeito coletivo diz que, apesar de pouco conhecida no início, a missão do curso/IES passou a ser mais disseminada, e seus objetivos passaram do contexto nacional para o global
COA e Gestão: O sujeito coletivo indica mudanças em elementos da cultura do curso que precisam ser preservadas, e que, embora haja um planejamento informal, há cobranças periódicas de ações.
A meta de internacionalização do curso, iniciada em 2010, ampliou e aperfeiçoou a sua missão, que foi repensada, rediscutida e redefinida em 2014, embora estivesse sendo discutida há muito. A missão ficou, então, mais ou menos assim: formar e preparar o estudante com qualidade e com maior desempenho para poder atuar no mercado competitivo, tanto nacional quanto global.

Em gestão recente, foi criado o Projeto Discovery em convênio com a Universidade de Illinois, com a meta de internacionalização. Por isso creio que uma das vertentes de nossa missão é continuar buscando o reconhecimento e credenciamento internacional, além de manter o nosso curso sempre na liderança.

Havia uma missão no departamento que se concretizava apenas pela influência das práticas dos professores-icones, mas não era seguida pelos demais docentes. Essa missão mudou um pouco devido às novas lideranças do departamento.

Contudo, tenho percebido fortes alterações nas crenças, valores e costumes, principalmente, por meio das pessoas que têm liderado o departamento na gestão e no exercício da docência das várias disciplinas do curso de Ciências Contábeis.

Hoje, embora haja um planejamento estratégico informal, há cobrança periódica de ações para assegurar os fins. Os professores que não se integram ao grupo acabam saindo para outro departamento, prevalecendo a cultura existente, que se aperfeiçoa com a contribuição de docentes mais novos.

Inicialmente o curso de Ciências Contábeis era visto como instrumental, só depois passou a ser visto criticamente, mas creio que os objetivos do curso ainda carecem de base conceitual, adequação de conteúdos em termos de reflexões críticas e práticas, para que os egressos daqui possam sair para assumir posições de comando nas áreas contábil e de controle. 
Com base nos referenciais teóricos e nos argumentos apresentados anteriormente, é possível deduzir que as 'crenças e valores expostos', ou os juízos de valor da dimensão em análise podem ser vistos nas descrições contidas nas categorias da Tabela 20: Missão; COA e Gestão; e Curso de Ciências Contábeis.

Geralmente as crenças e valores expostos dizem respeito ao que os docentes entendem sobre o aspecto em observação. Já as suposições básicas indicam o como se elaborou o entendimento do aspecto. É oportuno ressaltar que, visando obter melhor compreensão dos DSC analíticos contidos em cada uma das quatro dimensões vistas nas figuras, elaborou-se uma citação para cada uma, contendo um parágrafo sintético com os principais trechos dos DSC de cada categoria. No caso da missão, como há três categorias, existe três parágrafos.

[...] a missão anterior era ofertar a melhor formação em Contábeis no Brasil e América Latina, e a atual foi ampliada para um contexto global [...] por isso creio que uma das vertentes de nossa missão é continuar buscando o reconhecimento e credenciamento internacionais, além de manter o nosso curso sempre na liderança. [...]. Em gestão recente, foi criado o Projeto Discovery em convênio com a Universidade de Illinois, com a meta de internacionalização.

Havia uma missão no departamento que se concretizava apenas pela influência das práticas dos professores-ícones, mas não era seguida pelos demais docentes. Essa missão mudou um pouco devido às novas lideranças do departamento. Contudo tenho percebido fortes alterações nas crenças, valores, e costumes, principalmente por meio das pessoas que têm liderado o departamento [...]. Embora haja um planejamento estratégico informal, há cobrança periódica de ações para assegurar os fins. Os professores que não se integram ao grupo acabam saindo para outro departamento, prevalecendo a cultura existente, que se aperfeiçoa com a contribuição de docentes mais novos.

[...] o curso de Ciências Contábeis era visto como instrumental, só depois passou a ser visto criticamente, mas creio que os objetivos do curso ainda carecem de base conceitual, adequação de conteúdos em termos de reflexões críticas e práticas, para que os egressos daqui possam sair para assumir posições de comando nas áreas contábil e de controle.

Segundo Denison et al. (2012), uma missão bem definida fornece propósito e um conjunto de metas para a organização. Já Schein (2009) comenta que se deve obter um entendimento compartilhado da missão essencial e de suas funções manifestas. Pela citação anterior, é possível perceber o empenho do grupo quanto à diretriz de internacionalização da missão, o controle e acompanhamento de metas e objetivos, a responsabilidade e dedicação quanto à 
manutenção da COA do curso e a absorção de novos valores para a cultura da IES. Além disso, há o reconhecimento de que os objetivos do curso ainda carecem de base conceitual, e que é preciso aperfeiçoar este aspecto no processo ensino-aprendizagem para que se possa difundir, nos estudantes, um pensamento mais reflexivo e crítico-conceitual.

Na literatura empírica, Tierney (1988) descobriu que uma das causas dos bons resultados da IES pesquisada é que os docentes, técnicos e alunos eram bem informados pela liderança, embora informalmente, dos planos da IES. Já Denison e Mishra (1995) concluíram que as características de missão e consistência eram indicadoras de visão, direção e integração, sendo preditoras mais adequadas dos resultados positivos, o que parece ter sido o caso.

Os DSC da dimensão adaptabilidade externa, vinculados às suas respectivas categorias, estão apresentados na Tabela 21.

Tabela 21

DSC dos docentes da FEA/USP quanto à adaptabilidade externa

Questão 2: Qual o atual estágio da COA do curso de Ciências Contábeis da FEA, relativo à adaptabilidade externa? (abrange criação da mudança; foco no cliente [sociedade, mercado e estudantes]; e aprendizagem organizacional)

A trajetória do departamento tem sempre mostrado essa abertura para o novo. Hoje, com o projeto Discovery, busca-se autonomia, internacionalização $e$ uma proximidade maior com a realidade do mercado. Já há um costume periódico de docentes irem a Harvard e outras escolas de ponta para verificar casos, situações e formas de ensino para adaptação aqui no departamento.

Internacionalização: $O$ sujeito coletivo diz que o departamento sempre esteve aberto para o novo, e que a diretriz de internacionalização tem ambições, abrangendo a certificação internacional, ajuste nos conteúdos e intercâmbio de estudantes.
O convênio com a Universidade de Illinois, uma vez conduzido por dois anos, possibilitará à FEA ingressar com o processo de certificação internacional junto à $A A C S B$. Há duas vertentes no projeto: acreditação e mudança curricular. Na primeira buscase o duplo diploma e novas universidades; na segunda busca-se a adaptação global e sua manutenção ao longo do tempo.

Enfim, enquanto as IES do país nos enxergam como referência, nós pesquisamos as melhores escolas de Contabilidade do ambiente externo em um processo de internacionalização, agora intensificado com o projeto Discovery. 
As universidades atuais perderam aquela imagem sagrada das universidades inglesas e europeias de 700 anos atrás, quando a missão do docente era a busca da verdade e a responsabilidade de passá-la às novas gerações.

Mudanças na universidade: $O$ sujeito coletivo diz que o curso da USP tem priorizado a produção de profissionais como uma linha de produção industrial no mau sentido, se distanciando da missão sacra de universidades de 700 anos atrás.
Há no departamento uma preocupação em se adaptar, porém na direção de um prejuízo que atingiu a essência do que é uma universidade, distanciando-se daquela missão sacra e se aproximando mais de uma linha de produção industrial, que nos remete a um comportamento empresarial no mau sentido.

Há uma real necessidade de a universidade entender as demandas e necessidades da sociedade e do mercado profissional, e até buscar antecipar mudanças, mas ela não deve se orientar por elas.

No passado, a FEA/USP já buscava sempre inovar, mesmo sem ter objetivos globais bem definidos, e as metodologias usadas não eram tão sofisticadas $e$ intensas em métodos quantitativos como são hoje, tanto para o ensino como, principalmente, para a pesquisa e a produção científica.

Os alunos da FEA têm mais dificuldade que os de escolas particulares de ponta, porque nestas o objetivo geral é prepará-los para elaborar relatórios contábeis e demais obrigações, incluindo as fiscais, necessárias às organizações, a depender do seu tipo e regime de tributação, mas em médio e longo prazos nossos alunos têm mais potencial, porque são preparados para desenvolver o pensamento crítico-reflexivo; eles esperam que o docente equilibre a base conceitual com a prática porque a Contabilidade se atualiza e se adapta rápida e continuamente, em função da dinâmica patrimonial das organizações.

Outro aspecto, as avaliações feitas ao final do semestre (alunos avaliam professor X professor avalia a classe) têm contribuido para a melhoria $e$ adequação do processo ensino-aprendizagem às realidades externas e à integração entre docentes $e$ discentes; 
Continuação (ainda) da Tabela 21

\begin{tabular}{l|l}
\hline \multicolumn{1}{c|}{ Categorias } & \multicolumn{1}{c}{ Discurso do Sujeito Coletivo (DSC) } \\
\hline Continuação de ensino-aprendizagem & $\begin{array}{l}\text { A introdução do ensino à distância (EaD) aqui no } \\
\text { departamento, como em outras escolas, começou com } \\
\text { algumas disciplinas, mas vem aumentando } \\
\text { continuamente. Hoje podemos sentar frente a uma } \\
\text { onsino-aprendizagem: O sujeito coletivo indica que }\end{array}$ \\
$\begin{array}{l}\text { relevante em conteúdo conceitual que os de escolas } \\
\text { privadas de ponta que são mais tecnicistas, e que os } \\
\text { docentes, em geral, têm priorizado o papel ativo do do de aula, com algumas adaptações, mas sem } \\
\text { aluno no processo ensino-aprendizagem. }\end{array}$ & $\begin{array}{l}\text { prejuizo do ensino. O EaD também oferece condições } \\
\text { para que os alunos possam fazer os exercícios ou } \\
\text { casos, e resolver o problema da distância que muitos } \\
\text { alunos têm em relação ao campus, }\end{array}$ \\
& $\begin{array}{l}\text { Em suma, os professores têm participado ativamente } \\
\text { de aulas com metodologias diferentes e mais } \\
\text { participativas, que colocam o aluno como sujeito } \\
\text { ativo e o professor muito mais como um orientador } \\
\text { que estimula o estudante a refletir criticamente, a } \\
\text { trabalhar e discutir em grupos. }\end{array}$ \\
\hline
\end{tabular}

$\mathrm{Na}$ linha dos comentários anteriores, a dimensão adaptabilidade externa contém as crenças e valores expostos que estão descritas nas categorias apresentadas na Tabela 21: Internacionalização; Mudanças na universidade; e Ensino-aprendizagem.

O terceiro nível de cultura de Schein (2009) pode ser deduzido de trechos dos DSC da Tabela 21 nos três parágrafos seguintes, respectivamente às três categorias citadas anteriormente.

[...] A trajetória do departamento tem sempre mostrado essa abertura para o novo. Hoje [...] busca-se autonomia, internacionalização e uma proximidade maior com a realidade do mercado. [...] enquanto as IES do país nos enxergam como referência, nós pesquisamos as melhores escolas de Contabilidade do ambiente externo em um processo de internacionalização, agora intensificado com o projeto Discovery.

[...] as universidades atuais perderam aquela imagem sagrada das universidades inglesas e europeias de 700 anos atrás, quando a missão do docente era a busca da verdade e a responsabilidade de passá-la às novas gerações. [...] há no departamento uma preocupação em se adaptar, porém na direção de um prejuízo que atingiu a essência do que é uma universidade, distanciando-se daquela missão sacra e se aproximando mais de uma linha de produção industrial que nos remete a um comportamento empresarial no mau sentido.

[...] os alunos da FEA têm mais dificuldade que os de escolas particulares de ponta, porque nestas o objetivo geral é prepará-los para elaborar relatórios contábeis e demais obrigações [...], mas em médio e longo prazos nossos alunos têm mais potencial porque são preparados para desenvolver o pensamento crítico-reflexivo. 
Denison et al. (2012) comentam que esta dimensão geralmente traduz o entendimento que as entidades adaptáveis possuem sobre as mudanças do ambiente externo, rapidamente convertendo-as em ações. Contudo, eles acrescentam que entidades com propósito e direção já rigorosamente definidos são as menos capazes de se adaptar e, portanto, difíceis de mudar.

Embora pareça que a FEA esteja mais próxima do segundo tipo de organização, pelo fato de ser uma entidade pública, os trechos extraídos como síntese dos DSC da dimensão em análise mostram o contrário, ou seja, que o curso está sempre aberto para o novo. Este curso sempre foi a maior referência em Contabilidade no país e tem uma grande responsabilidade de manter esta reputação. Adicionalmente, apesar de o DSC central parecer contradizer os demais, não se pode esquecer o contexto geral da atual graduação em Ciências Contábeis no país (mesmo na FEA), que valoriza mais o caráter profissional do que o acadêmico em seus alunos.

Quanto a esse aspecto mais profissional do curso, Hofstede (2003) sustenta que essa é uma característica dos países com elevado controle de incerteza e sistema de codificação bem mais detalhado (Code Law), como Alemanha e Itália (e Brasil), onde as informações são as mesmas para os acionistas e para o físco, ao contrário de países com baixo controle de incerteza, como os Estados Unidos e o mundo anglo-saxônico, em que o regime de codificação é o Common Law. Acrescenta o autor que, devido à existência desses dois sistemas de codificação, é bem provável que nas sociedades em que o regime seja o Code Law, como no caso do Brasil, a profissão de contabilista ocupe uma posição inferior.

Essa observação parece muito oportuna para explicar, pelo menos no caso do Brasil, com honrosas exceções, essa ênfase no tecnicismo e no caráter prático da profissão, o que acarreta, em expressiva maioria, um desinteresse pelo caráter acadêmico do curso; também nos estudantes se observa uma resistência ao desenvolvimento do pensamento reflexivo e à busca da autonomia, e, até nos docentes, a carência de uma sólida cultura geral.

Os DSC da dimensão integração interna, vinculados às suas respectivas categorias, estão apresentados na Tabela 22: 
Tabela 22

DSC dos docentes da FEA/USP quanto à integração interna

\begin{tabular}{l} 
Questão 3: Qual o atual estágio da COA do curso de \\
interna? (abrange orientação da equipe; capacitação; \\
\hline Categorias \\
\hline
\end{tabular}

grade curricular e a diretriz de internacionalização.

Recentemente, repensamos todo o planejamento pedagógico do curso, conduzido pela coordenação, docentes e quase todos do departamento, cujo resultado está implantado desde 2013. Os docentes também se aperfeiçoaram para trabalhar neste novo modelo com novas tecnologias, metodologias de ensino, e novos recursos para ofertar aulas mais adaptadas ao contexto e perfil dos novos alunos. Atualmente, vivemos a abordagem da sala de aula, onde buscamos, muito fortemente, tirar desse ambiente o foco no professor e colocá-lo no aluno, que deve ser o sujeito ativo no processo de ensinoaprendizagem.

O projeto Discovery busca o equilibrio entre ensino e aprendizagem e nesse tipo de abordagem temos buscado desenvolver a participação ativa dos alunos em sala de aula, tornando-a mais dinâmica $e$ produtiva.

Creio que há um aspecto forte relativo a comportamentos e relações interpessoais. Quando há uma "química" entre o professor e a turma, as atividades transcorrem positivamente durante todo o semestre, mas há casos em que basta acontecer um fato ou conflito mal resolvido para se instalar uma mácula que muitas vezes compromete o desenrolar de todo o semestre. Embora, em geral, os alunos sejam abertos aos avanços tecnológicos e acesso rápido às informações, eles possuem uma resistência muito grande às inovações e mudanças nas metodologias de aulas dos docentes e aos processos de avaliação. 


Categorias

Discurso do Sujeito Coletivo (DSC)

Como somos uma universidade pública, temos um "turnover" baixo: os docentes só saem quando se aposentam. Na última década saíram de 30 a 35\% dos docentes, que foram repostos rapidamente, com o habitual rigor na seleção da FEA para a admissão de novos doutores.

Há uma reunião anual formal, em que quase todos os docentes participam, e nela ocorre a troca de

COA do curso: O sujeito coletivo trata de algumas características da COA do curso/FEA como: a trajetória dos docentes, da universidade, as inovações e a dinâmica das mudanças.
Liderança: O sujeito coletivo trata de características da liderança do curso na universidade pública, como: poder, formas de atuação e tomada de decisão. experiências de sucesso, de fracasso, inovações e oportunidades de melhoria. Em geral são reuniões demoradas, devido às resistências e às limitações de capacidade de transmissão e comunicação. Como o EaD é um dos temas que tem tido resistência por parte de docentes mais antigos, foram escolhidos docentes identificados com essa modalidade, que já estão em treinamento para se habilitar e atuar depois como multiplicadores.

Na dinâmica de mudanças aqui na FEA, percebe-se que há visões distintas quanto à melhoria contínua do ensino, pesquisa e extensão, mas estas não chegam a prejudicar a convergência no final.

\section{Visão positiva da liderança}

Uma característica da liderança na FEA é que ninguém é dono do departamento. Assim os gestores $e$ as prioridades sucedem-se sem turbulências através de grupos, conselhos e comissões, entre outros.

Para implantar o Projeto Discovery, o então coordenador geral da graduação da FEA foi enviado à Illinois para aprender, trazer e repassar os recursos necessários para o grupo de trabalho. As disciplinas do projeto são optativas, servindo de laboratório para, se bem-sucedidas, tornarem-se obrigatórias.

\section{Visão crítica da liderança}

Contudo, um problema aqui na FEA é a cobrança de bom desempenho dos docentes, mormente nas áreas de ensino e pesquisa, sem uma preocupação em identificar, de forma individual, o seu potencial $e$ vocação. Caso isso pudesse acontecer, os resultados poderiam ser bem melhores.

Com a meta de internacionalização e o projeto Discovery, busca-se maior abertura, engajamento $e$ disponibilidade dos docentes com os estudantes e com as mudanças. Contudo, devido às características da área pública, o poder discricionário de toda a gestão é mínimo, limitado a normas e regras muito rígidas, resultando em uma liderança pouco atuante no contexto operacional. 
Continuação (ainda) da Tabela 22

\begin{tabular}{|c|c|}
\hline Categorias & Discurso do Sujeito Coletivo (DSC) \\
\hline $\begin{array}{l}\text { Integração: O sujeito coletivo aborda como ocorre o } \\
\text { processo de integração entre os docentes do curso de } \\
\text { Ciências Contábeis no Departamento na FEA. }\end{array}$ & $\begin{array}{l}\text { Visão positiva da integração } \\
\text { A maioria dos docentes do departamento é composta } \\
\text { por doutores com dedicação integral }{ }^{16} \text {, e como o } \\
\text { campus é distante, isso propicia mais opçóes de } \\
\text { contato entre eles, criando condições para a troca de } \\
\text { experiências; há ainda o costume de viagens } \\
\text { periódicas de docentes ao exterior para fazer cursos, } \\
\text { participar de congressos, seminários e fóruns, entre } \\
\text { outros. Todos esses aspectos favorecem a nossa } \\
\text { vanguarda de conhecimento em Ciências Contábeis, } \\
\text { abrangendo ensino, pesquisa e extensão. } \\
\text { Uma vez por ano ocorre uma reunião formal com a } \\
\text { finalidade de integração interna entre os docentes e } \\
\text { coesão da equipe, mas como trabalhamos em uma } \\
\text { cidade universitária, estamos quase sempre } \\
\text { intercambiando ideias e experiências em situações } \\
\text { informais, como conversas pelos corredores elou na } \\
\text { hora do almoço. } \\
\text { Visão crítica da integração } \\
\text { Contudo, há } 20 \text { anos, o engajamento e integração no } \\
\text { departamento eram bem melhores do que hoje. } \\
\text { Embora o departamento na FEA/USP venha se } \\
\text { esforçando, o engajamento e integração atual dos } \\
\text { docentes é uma missão árdua e não há, em geral, } \\
\text { uma dedicação integral deles ao curso. }\end{array}$ \\
\hline
\end{tabular}

$\mathrm{Na}$ linha dos comentários anteriores, a dimensão integração interna contém, pelas suas categorias, as crenças e valores expostos que estão contidas nas descrições de cada uma delas na Tabela 22: Ensino-aprendizagem; COA do curso; Liderança; e Integração.

As suposições básicas ou valores da dimensão integração interna da Tabela 22 estão apresentados, respectivamente, de acordo com as quatro categorias já citadas.

Recentemente repensamos todo o planejamento pedagógico do curso [...]. Os docentes também se aperfeiçoaram para trabalhar neste novo modelo com novas tecnologias, metodologias de ensino [...] mais adaptadas ao contexto e perfil dos novos alunos. Atualmente, vivemos a abordagem da sala de aula, onde buscamos, muito fortemente, tirar desse ambiente o foco no professor e colocá-lo no aluno, que deve ser o sujeito ativo no processo de ensino-aprendizagem.

[...] temos um turnover baixo: os docentes só saem quando se aposentam [...]. Há uma reunião anual formal, em que quase todos os docentes participam, e nela ocorre a troca de experiências [...]. Na dinâmica de mudanças aqui na FEA, percebe-se que há visões

${ }^{16}$ Corresponde ao acrônimo RDIDP. 
distintas para a melhoria contínua do ensino, pesquisa e extensão, mas estas não chegam a prejudicar uma convergência no final.

Uma característica da liderança na FEA é que ninguém é dono do departamento. Assim os gestores e as prioridades sucedem-se sem turbulências através de [...] comissões [...], contudo, um problema aqui [...] é a cobrança de bom desempenho dos docentes, mormente nas áreas de ensino e pesquisa, sem uma preocupação em identificar, de forma individual, o seu potencial e vocação [...]; e devido às características da área pública, o poder discricionário da [...] gestão é mínimo, limitado a normas [...] muito rígidas, resultando em uma liderança pouco atuante no contexto operacional.

A maioria dos docentes do departamento é composta por doutores com dedicação integral, e como o campus é distante, isso propicia mais opções de contato entre eles, [...] a troca de experiências [...]; uma vez por ano ocorre uma reunião formal com a finalidade de integração interna entre os docentes [...], mas [...] estamos quase sempre intercambiando ideias e experiências em situações informais como conversas pelos corredores [...], contudo, há 20 anos, o engajamento e integração no departamento eram bem melhores do que hoje [...]. O engajamento [...] atual dos docentes é uma missão árdua e não há, em geral, uma dedicação integral deles ao curso.

Nessa dimensão, também chamada de envolvimento por Denison et al. (2012), os autores sustentam que os membros que compõem a organização estão fortemente comprometidos com suas atividades operacionais, e que possuem, além disso, a consciência de que suas atribuições estão diretamente ligadas aos objetivos organizacionais. Na citação, o curso está repensando todo o seu planejamento pedagógico, incluindo a adequação de metodologias de docentes, cita o baixo turnover dos docentes e destaca um aspecto positivo do curso, mas salienta duas críticas: uma quanto à liderança e gestão, indicando que o poder do gestor é limitado ou mínimo, ou seja, trata-se de uma característica da gestão pública; e a outra indicando que o engajamento e integração entre os docentes já foram bem melhores, e hoje representam uma missão árdua.

Na literatura empírica, os achados de Denison e Mishra (1995) indicam que os traços (ou dimensões) envolvimento (ou integração interna) e adaptabilidade externa são indicadores de flexibilidade, abertura e capacidade de resposta, sendo fortes preditores de crescimento. No caso, devido à característica pública da IES (FEA/USP), há limitações para o envolvimento.

Os DSC da dimensão consistência, vinculados às suas respectivas categorias, estão apresentados na Tabela 23: 
Tabela 23

DSC dos docentes da FEA/USP quanto à consistência

\begin{tabular}{c|c}
\hline $\begin{array}{l}\text { Questão 4: Qual o atual estágio da COA do curso de Ciências Contábeis da FEA, relativo à } \\
\text { consistência? (abrange acordo e coordenação; valores fundamentais; e integração) }\end{array}$ \\
\hline \multicolumn{1}{c}{ Categorias } & \multicolumn{1}{c}{ Discurso do Sujeito Coletivo (DSC) } \\
\hline & Embora nosso curso de Ciências Contábeis e sua estrutura \\
& sejam os menores entre os três departamentos existentes na \\
& FEA, creio que é o que mais tem evoluido, com a graduação \\
& mais bem avaliada, e que continua sendo uma referência e um \\
& diferencial até hoje no Brasil, na América Latina, e agora \\
& despontando no exterior.
\end{tabular}

Há, pelo menos, meio século de sólida coerência da COA do curso no Departamento/FEA quanto a sua alta qualidade, visibilidade e grande prestígio junto à sociedade e ao mercado

Curso de Ciências Contábeis: O sujeito coletivo aborda elementos do curso de Ciências Contábeis da FEA/USP, incluindo sua trajetória histórica, sua posição de destaque no país e no exterior, evolução do perfil de docentes e características desejadas dos egressos do curso. profissional, porém, por sermos uma entidade pública, as ações resultantes da gestão como um todo, e o processo de tomada de decisões, têm sido muito burocráticos e lentos.

Existe um forte empenho quanto à preservação e adequação da cultura do curso, desenvolvido e disseminado no Brasil pelos docentes-icones que nos antecederam, porque muitos dos novos docentes não são oriundos desta escola, e alguns não são da área contábil, como os docentes da área de Atuária, os quais não compreendem tanto este grande significado que o departamento tem no Brasil.

Busca-se, hoje, não o tipo de contador que registrava transações e guardava os livros da empresa, mas sim um contador com presença e atuação relevantes e crescentes nas organizações, agindo também como um agente de mudanças que contribui para o processo de tomada de decisões.

Não se trata de saudosismo ou coisas do tipo "na minha época é que era bom", mas não consigo perceber esse processo de engajamento e integração como eu notava há 20 anos. Acredito que o departamento deveria mudar sua filosofia para buscar se assemelhar a uma verdadeira universidade, afastando-se dessa visão de linha de produção empresarial.

A FEA/USP como universidade: $O$ sujeito coletivo aborda aspectos da FEA/USP como universidade, apontando problemas de gestão superior, revisão do seu papel, engajamento e integração entre os docentes e entre estes e a coordenação do curso, representando a gestão.

As atividades da universidade estão um pouco desintegradas, incluindo sua própria estrutura que conduz para a individualidade de seus membros, o que é um paradoxo em relação ao significado da palavra universidade. Aqui as faculdades têm vida própria e são isoladas umas das outras. Por exemplo: recebemos professores de outras faculdades da USP (Direito, Filosofia, Matemática, Humanas etc.) que dão as suas aulas no curso de Ciências Contábeis sem qualquer adequação do conteúdo à Contabilidade, e depois vão embora.

Um aspecto positivo na gestão da USP, e da FEA, em particular, é que não é perceptível, nas suas estruturas de poder, essa coisa de situação e de oposição, mesmo no cenário atual de grave crise financeira pela qual a USP vem passando. 
Continuação da Tabela 23

\begin{tabular}{l|l}
\hline Categorias & \multicolumn{1}{c}{ Discurso do Sujeito Coletivo (DSC) } \\
\hline & Tem sido grande a busca pela preservação da cultura do \\
& departamento/FEA, muito ligada ao carisma dos docentes-ícones \\
& do passado que construíram essa referência e que não estão mais \\
& presentes. Assim, os nossos desafios são grandes para buscarmos \\
& manter esse patamar de qualidade e, simultaneamente, fortalecer \\
& nossa liderança em função desse diferencial que possuímos.
\end{tabular}

Temos como elementos da COA, ritos e cerimoniais como: premiação dos melhores docentes; acompanhamento dos docentes aposentados; prêmios para os melhores trabalhos de dissertações e teses, entre outros. Também criamos uma sala de seniores para

COA da FEA/USP: O sujeito coletivo trata da evolução, preservação e aperfeiçoamento da COA do departamento de Contabilidade da FEA/USP, enfatizando alguns elementos como heróis, ritos, crenças, valores, tradições e liderança, entre outros.
Engajamento e integração: $O$ sujeito coletivo aborda características do processo de engajamento e integração dos membros do curso de Contabilidade da FEA/USP. os docentes aposentados, para que estes possam eventualmente vir aqui e trabalhar, para se sentirem ainda como parte do departamento.

Para manter a COA e sua coesão no departamento, há uma preocupação na seleção de novos docentes para identificar aqueles que melhor possam se integrar às crenças, valores, tradição, entre outros elementos da cultura do curso. Apesar das mudanças contínuas na sociedade, e de os jovens de hoje possuirem uma visão diferenciada dos mais antigos, eles percebem entendem que aqui no curso existe uma cultura com características próprias já estabelecidas.

A COA do departamento/FEA/USP tem melhorado, o ambiente interno está melhor, embora seja dificil atingir o ideal como, por exemplo, minimizar o isolamento entre docentes e também entre docentes e alunos. A nossa COA é formada por subculturas; as áreas de Mercado de Capitais, Contabilidade Societária e Contabilidade Gerencial são um exemplo disso. As crenças, valores e tradições já estão no DNA da COA no departamento, portanto dificeis de serem mudadas, só sendo possíveis os aperfeiçoamentos, mantendo-se as coisas boas, úteis e atuais.

Há uma desvantagem da FEA/USP, assim como em outras IES públicas, em relação às IES privadas, que é o aperfeiçoamento moroso da COA, mormente quanto ao processo de integração e engajamento dos seus membros, o qual só é possível perceber de forma gradativa.

O engajamento é uma das coisas mais dificeis numa universidade pública. Na cultura brasileira há trabalhos acadêmicos muito sedutores, mas sem a contrapartida salarial proporcional para compensar o esforço. Quando estamos na posição de gestores, temos quase que pedir "pelo amor de Deus" para os colegas nos ajudarem nos trabalhos. Se não fosse a Fundação FIPECAFI, nós não conseguiríamos nos manter como referência há tanto tempo conquistada.

Enfim, o processo de engajamento e integração na universidade pública é muito lento em relação às mudanças contínuas, devido às características burocráticas da gestão. Contudo, há certa tendência de que esse processo de engajamento ocorra de forma mais intensa na área de Contabilidade Financeira, em relação às demais áreas da Contabilidade. 
Seguindo a linha dos comentários anteriores, a última dimensão, consistência, contém as crenças e valores expostos, ou juízos de valor dos docentes, extraídos das descrições de suas quatro categorias: Curso de Ciências Contábeis; A FEA/USP como universidade; COA da FEA/USP; e Engajamento e integração.

As suposições básicas ou valores podem ser vistos nesta síntese dos DSC da última dimensão na Tabela 23, respectivamente às suas quatro categorias já citadas.

Embora o nosso curso [...] seja o menor entre os três departamentos [...], creio que é o que mais tem evoluído, com a graduação mais bem avaliada [...]. Há, pelo menos, meio século de sólida coerência da COA do curso [...] quanto a sua alta qualidade [...] e grande prestígio junto à sociedade e mercado [...], porém por sermos uma entidade pública, as ações resultantes da gestão [...] têm sido muito burocráticas e lentas. [...]. Existe ainda um forte empenho quanto à preservação e adequação da cultura do curso [...] disseminado no Brasil pelos docentes-ícones que nos antecederam porque muitos dos novos docentes não são oriundos desta escola [...]. Busca-se, hoje, não o tipo de contador que registrava [...], mas sim um contador com presença e atuação relevantes e crescentes nas organizações [...] que contribui para o processo de tomada de decisões.

Não se trata de saudosismo [...], mas não consigo perceber esse processo de engajamento e integração como eu notava há 20 anos [...]. As atividades da universidade estão um pouco desintegradas, incluindo sua própria estrutura, que conduz a uma individualidade de seus membros, o que é um paradoxo em relação à palavra universidade. Aqui as faculdades [...] são isoladas umas das outras. [...]: recebemos professores de outras faculdades da USP [...] que dão as suas aulas [...] sem qualquer adequação do conteúdo à Contabilidade e depois vão embora [...]. Um aspecto positivo na gestão da USP e da FEA [...] é que não é perceptível, nas suas estruturas de poder, essa coisa de situação e de oposição, mesmo no cenário atual de grave crise financeira pela qual a USP vem passando.

[...] os nossos desafios são grandes para buscarmos manter esse patamar de qualidade e fortalecer a nossa liderança em função desse diferencial que possuímos, ligado ao carisma dos docentes-ícones [...] que não estão mais presentes [...]. Temos como elementos da COA ritos e cerimoniais como: premiação dos melhores docentes; [...] os prêmios de melhores trabalhos de dissertações e teses [...]. Para manter a COA e sua coesão no departamento, já há uma preocupação na seleção de novos docentes para identificar aqueles que melhor possam se integrar à [...] cultura do curso [...]. A nossa COA é formada por subculturas; as áreas de Mercado de Capitais, Contabilidade Societária e Contabilidade Gerencial são um exemplo disso. As crenças, valores e tradições já estão no DNA da COA no departamento, portanto difíceis de serem mudadas $[\ldots]$.

Há uma desvantagem da FEA/USP, assim como em outras IES públicas, em relação às IES privadas, que é o aperfeiçoamento moroso da COA, mormente quanto ao processo de integração e engajamento de seus membros [...]. O engajamento é uma das coisas mais difíceis numa universidade pública. [...] há trabalhos acadêmicos muito sedutores, 
mas sem a contrapartida salarial proporcional [...]. Quando estamos na posição de gestores, temos quase que pedir "pelo amor de Deus" para os colegas nos ajudarem nos trabalhos. Se não fosse a Fundação FIPECAFI, nós não conseguiríamos nos manter como referência há tanto tempo conquistada [...] há certa tendência de que esse processo de engajamento ocorra de forma mais intensa na área de Contabilidade Financeira [...].

Denison et al. (2012) mencionam que nesta dimensão está a compreensão de que a eficácia das organizações é influenciada fortemente pela coerência e a boa integração do seu ambiente interno, alicerçado em um conjunto de valores fundamentais. Schein (2009) denomina essa conjugação de aspectos 'certezas profundas contributivas na formação das suposições básicas compartilhadas', nas quais ele busca explicar, além do que é real ou não nas organizações, a natureza simbólica das atividades humanas em constante interação operacional, destacando relacionamentos, formas de cooperação ou competição e grupos.

Percebem-se características antagônicas nessas citações ligadas à COA do curso na FEA, que foram mais intensas em quantidade e qualidade. Novamente se observam aspectos positivos de satisfação quanto à alta qualidade e visibilidade do curso, sendo a mais alta referência no país, apesar de se reconhecer os grandes desafios para manter esses aspectos. Porém, são citados alguns elementos e características da COA que destacam a morosidade no seu aperfeiçoamento e a limitação de poderes da gestão, por ser uma entidade pública e, mais uma vez, se enfatiza que o engajamento dos docentes é muito difícil e que se nota um pouco mais de integração nas áreas de Contabilidade Societária e Financeira, Mercado de Capitais e Contabilidade Gerencial.

A partir do referencial de Denison et al. (2012), parece que a cultura do curso na FEA é sólida, mas ainda lastreada no passado, embora a responsabilidade e empenho dos atuais docentes e gestores seja grande, com resultados expressivos quanto à internacionalização e convênio com entidades externas, visando credenciamentos e reconhecimentos internacionais. No entanto, as características burocráticas e de limitação de poder da administração pública parecem representar um entrave para a dinamização da integração e da melhoria, quanto à coesão, do ambiente interno operacional e acadêmico. 


\subsubsection{Resultados e análise do levantamento junto aos alunos do curso de Ciências Contábeis da FEA/USP}

Nesta subseção estão apresentados os resultados do survey realizado com 122 alunos do curso de Ciências Contábeis da FEA/USP, por meio da aplicação de questionários em sala de aula. As respostas foram inseridas no sistema eletrônico 'QuestionPro', conforme referido no capítulo 3.

Do total de 122 alunos, 71 (58,2\%) são do sexo masculino e 51 (41,8\%) do sexo feminino. Quanto ao período, 95 alunos (77,87\%) são do período noturno e 27 alunos (22,13\%) são do período vespertino. Com relação ao semestre que os alunos estavam cursando, os dados estão apresentados na Figura 10.

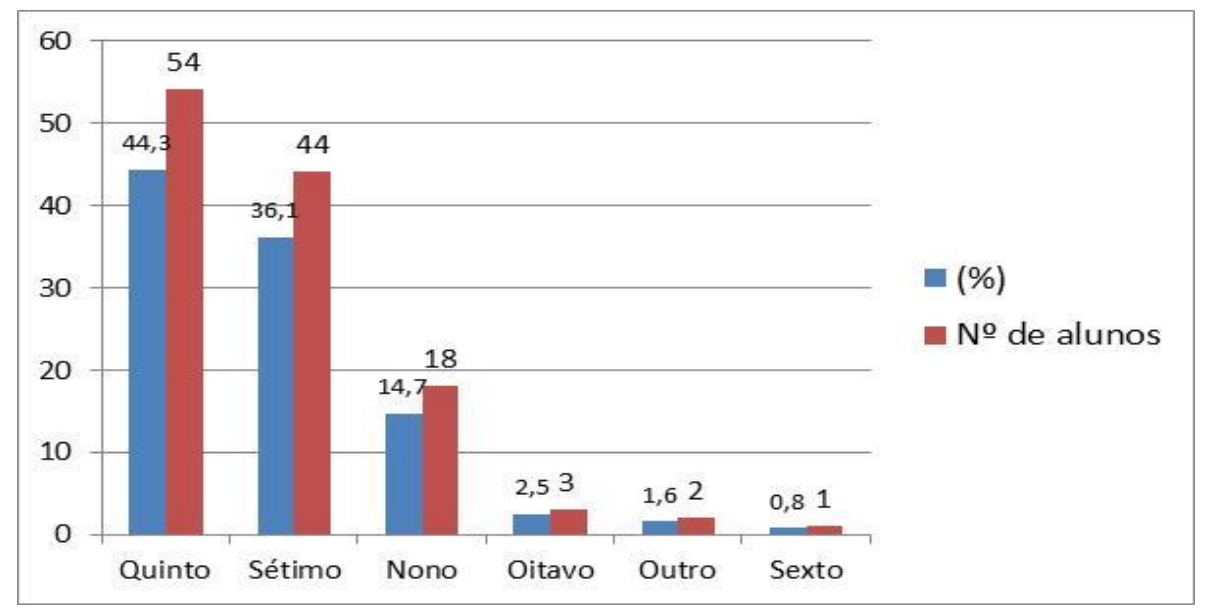

Figura 10. Distribuição dos respondentes por semestre letivo (FEA/USP)

O perfil das respostas dos alunos à pergunta "Você trabalha, faz estágio ou estuda?", pode ser visto na Figura 11. 


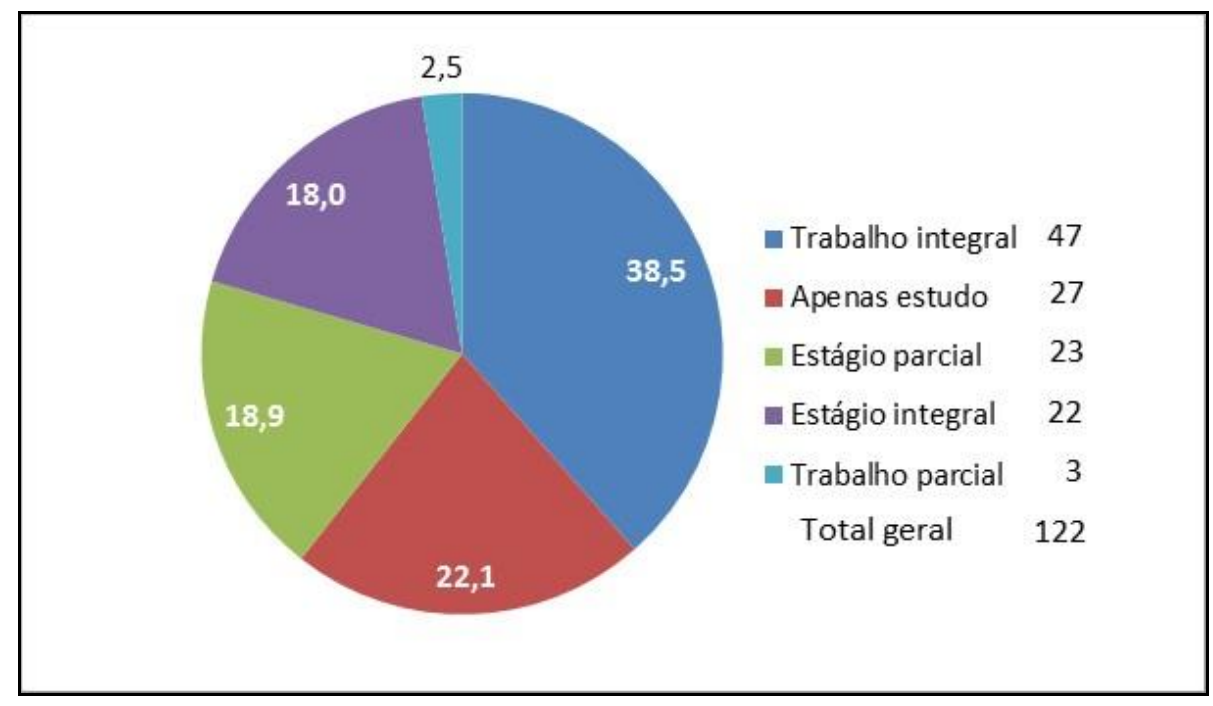

Figura 11. Inserção no mercado de trabalho dos alunos do curso (FEA/USP)

Pelo que se observa na Figura 11, há uma forte indicação de que os alunos que apenas estudam (27 ou 22,1\%) pertençam ao período vespertino apresentados na Figura 10.

As respostas dos alunos, apresentadas na Tabela 24, a seguir, foram obtidas por meio do questionário e dos procedimentos apresentados na seção 3.6 do capítulo 3. Na tabela as questões estão apresentadas de forma abreviada, por questão de espaço. É oportuno frisar que as 16 questões originais do questionário aparecem como afirmações. Portanto, ao longo deste capítulo e do próximo, quando há referência a estas questões, elas podem ser apresentadas das duas formas, como afirmações ou como questões. 
Tabela 24

\section{Resultados do survey com os alunos do curso de Ciências Contábeis da FEA/USP}

\begin{tabular}{|c|c|c|c|c|c|c|c|c|c|c|c|}
\hline \multirow[t]{2}{*}{ Dimensões } & \multirow{2}{*}{ Questões } & \multicolumn{2}{|c|}{$\begin{array}{c}\text { Discordo } \\
\text { totalmente } \\
\end{array}$} & \multicolumn{2}{|c|}{$\begin{array}{c}\text { Discordo } \\
\text { parcialmente }\end{array}$} & \multicolumn{2}{|c|}{ Indiferente } & \multicolumn{2}{|c|}{$\begin{array}{c}\text { Concordo } \\
\text { totalmente }\end{array}$} & \multicolumn{2}{|c|}{$\begin{array}{c}\text { Concordo } \\
\text { parcialmente }\end{array}$} \\
\hline & & $\mathbf{N}$ & $\%$ & $\mathbf{N}$ & $\%$ & $\mathbf{N}$ & $\%$ & $\mathbf{N}$ & $\%$ & $\mathbf{N}$ & $\%$ \\
\hline \multirow{4}{*}{ Missão } & Ações da direção indicam que ela segue a missão da IES & 2 & 1,6 & 25 & 20,5 & 38 & 31,1 & 44 & 36,1 & 13 & 10,7 \\
\hline & Coordenação controla metas e objetivos para assegurar o seu sucesso & 5 & 4,1 & 24 & 19,7 & 18 & 14,8 & 59 & 48,4 & 16 & 13,1 \\
\hline & Metodologias dos docentes são adequadas aos objetivos do curso e da IES & 4 & 3,3 & 25 & 20,5 & 19 & 15,6 & 62 & 50,8 & 12 & 9,8 \\
\hline & Práticas docentes adequadas ao que se espera do contador no futuro. & 6 & 4,9 & 21 & 17,2 & 11 & 9,0 & 58 & 47,5 & 26 & 21,3 \\
\hline \multirow{4}{*}{$\begin{array}{c}\text { Adaptabilidade } \\
\text { Externa }\end{array}$} & Desempenho nos exames externos afetam Gestão na tomada de decisões & 11 & 9,0 & 9 & 7,4 & 56 & 45,9 & 34 & 27,9 & 12 & 9,8 \\
\hline & Docentes trazem temas práticos do mercado profissional para a sala de aula & 6 & 4,9 & 17 & 13,9 & 5 & 4,1 & 64 & 52,5 & 30 & 24,6 \\
\hline & $\begin{array}{l}\text { Docentes procuram atualizar alunos com realidade do mercado profissional } \\
\text { Docentes buscam se integrar com alunos na melhoria do ensino- }\end{array}$ & 6 & 4,9 & 14 & 11,5 & 9 & 7,4 & 61 & 50,0 & 32 & 26,2 \\
\hline & aprendizagem & 5 & 4,1 & 29 & 23,8 & 21 & 17,2 & 52 & 42,6 & 15 & 12,3 \\
\hline \multirow{4}{*}{$\begin{array}{c}\text { Integração } \\
\text { Interna }\end{array}$} & Alunos dispõem de informações suficientes para o bom andamento do curso & 1 & 0,8 & 15 & 12,3 & 9 & 7,4 & 62 & 50,8 & 35 & 28,7 \\
\hline & Existe integração entre a coordenação e os docentes do curso & 9 & 7,4 & 32 & 26,2 & 23 & 18,9 & 44 & 36,1 & 14 & 11,5 \\
\hline & Existe uma cultura acadêmica específica no curso de Ciências Contábeis & 7 & 5,7 & 10 & 8,2 & 49 & 40,2 & 37 & 30,3 & 19 & 15,6 \\
\hline & Eu me sinto motivado ao aprendizado pelos docentes & 8 & 6,6 & 21 & 17,2 & 16 & 13,1 & 57 & 46,7 & 20 & 16,4 \\
\hline \multirow{4}{*}{ Consistência } & Promessas da coordenação são cumpridas pelas práticas docentes & 5 & 4,1 & 26 & 21,3 & 35 & 28,7 & 47 & 38,5 & 9 & 7,4 \\
\hline & COA do curso na IES indica o seu compromisso & 8 & 6,6 & 25 & 20,5 & 21 & 17,2 & 49 & 40,2 & 19 & 15,6 \\
\hline & Práticas dos docentes indicam que eles estão integrados com o curso & 2 & 1,6 & 18 & 14,8 & 16 & 13,1 & 60 & 49,2 & 26 & 21,3 \\
\hline & Integração entre coordenação e docentes apontam sólida liderança & 7 & 5,7 & 21 & 17,2 & 52 & 42,6 & 31 & 25,4 & 11 & 9,0 \\
\hline
\end{tabular}


Houve maior concentração de escolhas na opção 'concordo parcialmente', em 13 das 16 questões. Contudo, ao se comparar os somatórios das duas opções de concordância com as outras três opções, percebe-se que em seis das 16 questões os alunos discordam ou são indiferentes. Esses resultados ocorreram nas dimensões 'integração interna' e 'consistência', com duas questões cada. Nas demais dimensões, só ocorreu uma observação para cada.

Ao se considerar as respostas dos alunos como uma proxy do nível de satisfação dos alunos no estudo de Uprety e Chhetri (2014), comparado com os resultados da avaliação total das dimensões deste estudo, houve coerência em três delas: na adaptabilidade externa, na integração interna (ou envolvimento), e, por último, na consistência. Apenas na dimensão missão não houve coerência entre os dois estudos. Ela foi bem avaliada nesta pesquisa, ao contrário da avaliação encontrada pelos referidos autores.

Missão: observa-se que a maioria dos alunos parece não acreditar muito na primeira assertiva (as ações da direção [...]). No entanto, há indicação de que a maioria deles está de acordo com as demais afirmações, principalmente as duas últimas, que tratam de metodologias e práticas docentes.

Adaptabilidade externa: a maioria dos alunos revela ter uma forte crença quanto à segunda e terceira afirmações, que tratam da atualização do curso pelos docentes para adaptálo à realidade do mercado profissional. Eles creem na integração entre docentes e discentes, mas em menor grau, e acreditam que os exames externos influem muito pouco na gestão. Esta dimensão está consistente com o nível de satisfação dos alunos encontrado por Uprety e Chhetri (2014).

Integração interna: a maioria dos alunos crê fortemente que dispõe de informações suficientes para o bom andamento do curso. Contudo, há indícios de que eles não acreditam que exista tanta integração entre a coordenação e os docentes, e também que haja uma COA específica no curso. A maioria $(63,1 \%)$ dos alunos sente-se motivada pelos docentes para o aprendizado. Apesar da pouca crença nas duas questões intermediárias, há indicação de que a avaliação global desta dimensão está consistente com os achados de Uprety e Chhetri (2014). 
Consistência: esta foi a dimensão com menor nível de concordância pelos alunos, exceto pela terceira afirmação (práticas dos docentes indicam sua integração com o curso), que obteve 70,5\% das escolhas de concordância. Observa-se que 54,1\% dos alunos revelam não crer ou têm dúvidas sobre a primeira afirmação (promessas da coordenação...), e 65,6\% também têm o mesmo sentimento com relação à quarta questão (integração entre coordenação e docentes indica presença de forte liderança). Essa dimensão também ficou em terceiro lugar no nível de satisfação dos alunos, segundo os achados de Uprety e Chhetri (2014).

Em geral, a maioria dos alunos achou positiva a conduta em todas as dimensões da COA do curso de Ciências Contábeis da FEA/USP. No entanto, em ordem decrescente de importância, os alunos foram mais favoráveis às dimensões adaptabilidade externa, missão, integração interna e consistência. Pelo menos, entre as três primeiras, estão as duas que Schein (2009) considera como as mais relevantes na pesquisa de cultura organizacional.

Na sequência, existe ainda a questão 17, com a pergunta: O que você acha que deve mudar no curso para que ele se torne tão atual quanto o dinâmico mercado do contador? Nesta pergunta, os alunos podiam escolher mais de uma opção. As respostas obtidas estão apresentadas na Tabela 25 .

Tabela 25

Escolhas dos alunos quanto às mudanças no curso da FEA

\begin{tabular}{|c|c|}
\hline Alternativa & $\begin{array}{c}\mathrm{N}^{\circ} \text { de } \\
\text { respostas }^{17}\end{array}$ \\
\hline O curso deveria ter uma prática tão intensa quanto a teoria & 71 \\
\hline O curso deveria fazer mais eventos com pessoas ou empresas do mercado profissional & 68 \\
\hline Os docentes deveriam trabalhar mais com problemas e estudos de caso & 56 \\
\hline Atualização dinâmica da grade curricular & 52 \\
\hline Incentivo maior à pesquisa & 29 \\
\hline
\end{tabular}

Além da primeira e segunda questões, houve maior concentração (quase a mesma) de escolhas na terceira e quarta opções. Na última opção, no entanto, o número menor de escolhas parece indicar que já exista um nível razoável de incentivo à pesquisa e iniciação científica.

\footnotetext{
${ }^{17}$ As respostas não estão em percentuais porque os alunos podiam escolher mais de uma opção.
} 


\subsubsection{Síntese da comparação das percepções dos docentes e discentes (FEA/USP)}

Nesta síntese comparativa, buscou-se confrontar os resultados apurados entre o survey com os alunos e trechos dos DSC, por dimensão, elaborados pelo autor com base nos depoimentos dos docentes do departamento EAC.

Tabela 26

Síntese comparativa entre as percepções de docentes e discentes sobre a COA do curso de Ciências Contábeis da FEA/USP

\begin{tabular}{|c|c|c|}
\hline DIMENSÃO & PERCEPÇÃO DOS DOCENTES & PERCEPÇÃO DOS ALUNOS \\
\hline Missão & $\begin{array}{l}\text { A diretriz de internacionalização parece ter } \\
\text { ampliado a missão do EAC e a sua } \\
\text { responsabilidade em manter o curso sempre } \\
\text { na liderança. Busca-se empenho em } \\
\text { desenvolver a reflexão crítica dos discentes, } \\
\text { embora ainda haja espaço para aprimorar } \\
\text { métodos e base conceitual. }\end{array}$ & $\begin{array}{l}\text { Há indicação, pelas avaliações positivas } \\
\text { das três últimas afirmações Controle de } \\
\text { metas...; metodologias dos docentes...; e } \\
\text { práticas docentes...), de que esses } \\
\text { resultados estão consistentes com os DSC } \\
\text { dos docentes, principalmente nas duas } \\
\text { últimas afirmações. }\end{array}$ \\
\hline $\begin{array}{c}\text { Adaptabilidade } \\
\text { externa }\end{array}$ & $\begin{array}{l}\text { O EAC visa objetivos maiores que os } \\
\text { ofertados pelos exames externos. Ele tem se } \\
\text { aberto, cada vez mais, para o novo, buscando } \\
\text { novas formas de ensino e trazendo o mercado } \\
\text { profissional para a sala de aula. Existe ainda o } \\
\text { empenho, mediante as avaliações internas, de } \\
\text { melhorar o ensino-aprendizagem. }\end{array}$ & $\begin{array}{l}\text { Nessa dimensão houve a maior coerência } \\
\text { entre alunos e docentes, iniciando pelos } \\
\text { exames externos. As duas afirmações } \\
\text { seguintes indicam bom nível de satisfação } \\
\text { e, até mesmo na última questão, a maioria } \\
\text { das escolhas recaiu sobre as opções de } \\
\text { concordância }(54,9 \%) \text {. }\end{array}$ \\
\hline $\begin{array}{c}\text { Integração } \\
\text { interna }\end{array}$ & $\begin{array}{l}\text { Nessa dimensão encontram-se os maiores } \\
\text { desafios para a melhoria do curso. Seu } \\
\text { planejamento pedagógico foi repensado com } \\
\text { o aperfeiçoamento dos docentes para colocar } \\
\text { o aluno como sujeito ativo do processo. Os } \\
\text { aspectos mais críticos estão nas limitações da } \\
\text { liderança em buscar engajar e integrar mais os } \\
\text { docentes nas atividades do EAC. }\end{array}$ & $\begin{array}{l}\text { A primeira questão (quanto à eficácia do } \\
\text { sistema de informações para alunos) foi a } \\
\text { que obteve o maior número de escolhas } \\
(79,5 \%) \text {. A maioria }(63,1 \%) \text { também se } \\
\text { sente motivada pelos docentes. Exceto } \\
\text { pelas duas questões centrais, os resultados } \\
\text { são favoráveis nesta fase, que ficou pouco } \\
\text { coerente com a percepção dos docentes. }\end{array}$ \\
\hline Consistência & $\begin{array}{l}\text { O empenho pela preservação da cultura, das } \\
\text { crenças e valores, são os destaques dessa } \\
\text { dimensão. Há ainda a ênfase em preparar um } \\
\text { contador com presença crescente no mercado. } \\
\text { Contudo, há ciência de que a IES está atuando } \\
\text { de forma não muito coesa, e que a COA } \\
\text { precisa melhorar no aspecto de liderança e de } \\
\text { engajamento/integração. }\end{array}$ & $\begin{array}{l}\text { Esta dimensão foi a que obteve menos } \\
\text { votos, exceto para a terceira afirmação, que } \\
\text { obteve } 70,5 \% \text { das escolhas (práticas dos } \\
\text { docentes...). Há razoável crença na COA } \\
\text { do EAC, mas } 65,6 \% \text { discordam ou têm } \\
\text { dúvidas sobre a presença de sólida } \\
\text { liderança. Parece haver certa coerência } \\
\text { com a percepção dos docentes. }\end{array}$ \\
\hline
\end{tabular}

Pela análise das percepções dos docentes e alunos, percebe-se que eles estão coerentes em três das quatro dimensões: missão, adaptabilidade externa e integração interna. Por meio desse entendimento, há indicação de consistência entre esses resultados e as duas questões 
fundamentais de Schein (2009), adaptação externa e integração interna. Essas duas questões também estão presentes nos achados de Uprety e Chhetri (2014).

Isto sugere que os alunos, além de conhecerem bem o curso e a FEA/USP, parecem estar satisfeitos por serem seus discentes. Essa dedução é fortalecida pela observação, nas respostas do questionário sobre as escolhas dos alunos, de que a soma das opções 'concordo' foi superior à soma das opções ‘discordo' em todas as dimensões.

Na sequência, foram selecionados trechos dos DSC apresentados nas tabelas anteriores, relativos a métodos e técnicas docentes, e apresentados a seguir para auxiliar a análise comparativa com os referenciais teóricos de práticas docentes, apresentados na seção 3.4.

[...] os professores têm participado ativamente de aulas com metodologias diferentes e mais participativas, que colocam o aluno como sujeito ativo e o professor muito mais como um orientador que estimula o estudante a refletir criticamente, a trabalhar e discutir em grupos.

[...] os docentes também se aperfeiçoaram para trabalhar neste novo modelo globalizado de ensino-aprendizagem, com novas tecnologias, metodologias de ensino e novos recursos, para ofertar aulas mais adaptadas ao contexto e perfil dos novos alunos.

[...] os objetivos do curso ainda carecem de base conceitual, e adequação de conteúdos em termos de reflexões críticas e práticas, para que os egressos possam sair para assumir posições de comando nas áreas contábil e de controle.

[...] as avaliações feitas ao final do semestre [...] têm contribuído para a melhoria e adequação do processo ensino-aprendizagem às realidades externas [...].

[...] já existe um costume periódico de docentes irem a Harvard e outras escolas de ponta para verificar casos, situações e formas de ensino, para adaptação aqui no departamento. Nessas viagens, eles fazem cursos, participam de congressos, seminários e fóruns, entre outros.

[...] atualmente, vivemos a abordagem da sala de aula, onde buscamos, muito fortemente, tirar deste ambiente o foco no professor e colocá-lo no aluno, que deve ser o sujeito ativo no processo de ensino-aprendizagem.

[...] o atual processo ensino-aprendizagem do curso necessita que o docente equilibre a base conceitual com a prática, porque a contabilidade se atualiza e se adapta rápida e continuamente em função da dinâmica patrimonial das organizações.

De acordo com esses trechos dos DSC, é possível sugerir que as práticas dos docentes do curso de Ciências Contábeis da FEA/USP estão próximas daquelas relacionadas nas categorias de conhecimento apresentados na seção 3.4, tais como teórico-profissional, didático, docente, interpessoal e/ou psicológico e geral. Pode-se sugerir, ainda, que a maioria dos docentes deste curso parece buscar, de forma contínua, a melhoria das suas práticas. 
A inferência anterior também se baseia no grau de qualificação do quadro docente do curso da FEA, que possui 40 professores que são, no mínimo, doutores, dos quais seis são titulares e cinco são livres-docentes. Dos 40 doutores, 18 são professores e orientadores dos programas de mestrado e doutorado, sendo que apenas um destes, por enquanto, atua apenas no mestrado. Em outras palavras, $44 \%$ dos docentes ensinam e orientam nos programas de mestrado e doutorado.

Esta seção é finalizada com elementos para contribuir à resposta da questão da pesquisa (Qual o atual estágio da cultura organizacional acadêmica nas Instituições de Ensino Superior que mantêm graduação em Ciências Contábeis?). Os comentários relativos às hipóteses e tese estão tratados na seção 4.3 de fechamento deste capítulo.

A COA do curso de Ciências Contábeis da FEA/USP, pelos vários aspectos apresentados nas quatro dimensões, parece ter solidez acadêmica e grande potencial e empenho para continuar preservando e/ou aumentando a sua cultura de alta referência, visibilidade e posicionamento estratégico, tanto no contexto nacional quanto internacional. Percebe-se que a cultura do curso tem influenciado e continua influenciando os resultados a serem obtidos. $\mathrm{O}$ poder da Cultura Organizacional no ambiente acadêmico, pela tradição da universidade e pelo elevado e regular nível de referência do curso no país, impõe responsabilidades às novas gerações de docentes, que precisam preservar o seu alto desempenho.

$\mathrm{Na}$ literatura empírica, seis dos oito trabalhos apresentaram aspectos comuns em seus achados: a característica de que os processos ou dimensões culturais estão relacionados positivamente com melhores resultados no desempenho, incluindo o artigo de Uprety e Chhetry (2014) que trata da relação entre dimensões da cultura e o nível geral de satisfação dos estudantes. Esses trabalhos destacaram ainda a importância da liderança como um dos elementos que mais influencia a eficácia no desempenho de forma geral.

O assunto internacionalização do curso da FEA foi o que mais se repetiu nos DSC baseados na fala dos docentes. A diretriz de internacionalização, com o projeto Discovery, em convênio com a Universidade de Illinois, deverá possibilitar o credenciamento na AACSB, permitindo a consolidação do reconhecimento internacional do curso de Ciências Contábeis. 
Essa busca pelo novo parece ser uma constante, a julgar pelos DSC baseados na fala dos docentes.

Contudo, a COA do curso de Ciências Contábeis apresenta também questões críticas, algumas, aparentemente, de difícil solução, tais como:

a) pela sua característica de organização pública, a universidade é lenta na tramitação de assuntos que envolvem tomadas de decisão relevantes que tenham impacto econômicofinanceiro, e os cargos de chefia ou comando possuem poder discricionário limitado, o que se reflete em uma liderança dependente de habilidade política para quem a ocupa. Este resultado está consistente com um dos achados de Schroeder (2010), de que a liderança é determinante para a cultura e com os achados de Souza Pires e Macêdo (2006).

b) em decorrência do exposto na alínea anterior, é muito difícil o processo de engajamento e integração dos docentes, constatado nos DSC descritos na seção 4.1.2. Esse engajamento e integração parecem ter consistência parcial com um dos achados de Locke e Guglielmo (2006), quando estes comentam a importância do papel dos líderes organizacionais no planejamento e implementação de uma mudança planejada, por meio de ações sobre as subculturas (grupos), e que estas mostraram diferenças significativas, sendo um fator primordial para o sucesso de programas de mudança planejada; e

c) a gestão acadêmica, sugerida nos DSC baseados na fala dos docentes, precisa rever cuidadosamente o processo ensino-aprendizagem, porque ao longo do tempo tem crescido a impressão de que este se assemelha a uma linha de produção industrial no mau sentido, com mais ênfase em traços tecnicistas do que acadêmicos. Segundo Hogan e Coote (2013), a forma como as camadas de cultura organizacional, especialmente as normas, artefatos e comportamentos inovadores, medem parcialmente o desempenho da organização parece contribuir para a implantação de formas inovadoras do processo ensino-aprendizagem.

Em síntese, o desempenho de uma organização e, mais precisamente nesse caso, das instituições de ensino superior, depende e é influenciado de forma relevante pela força e solidez da sua cultura organizacional. 


\subsection{Curso de Ciências Contábeis do DCIS/UEFS}

Esta seção subdivide-se em 4 subseções: i) a primeira contém um breve histórico do curso do DCIS/UEFS, a partir de documentos internos e externos; ii) a segunda apresenta os resultados das entrevistas com os docentes, começando com uma retrospectiva histórica do curso na visão dos docentes entrevistados; iii) a terceira apresenta os resultados do levantamento feito com os 84 alunos do curso; e iv) a quarta apresenta uma síntese, confrontando os resultados dos docentes e dos alunos, e algumas conclusões.

\subsubsection{Breve histórico do Curso de Ciências Contábeis do DCIS/UEFS}

De acordo com o portal da UEFS (2015a), em 1968 o governo baiano formalizou o Plano Integral de Educação, uma política educacional voltada para ampliar e expandir o sistema de ensino em todos os níveis, com o objetivo de formar quadros para atender ao processo de industrialização no Estado. Este processo ganhou impulso com a criação do Centro Industrial de Aratu (CIA), em 1966, a implantação do Polo Petroquímico de Camaçari, na década de 1970, e, mais recentemente, a construção do Complexo Automotivo Ford (Uderman, 2006). Assim, iniciou-se a interiorização do ensino superior com a instalação de Faculdades de Formação de Professores nas principais cidades do interior, nas quais funcionavam as sedes das regiões administrativas do Estado, que passaram a atuar como distritos geoeducacionais.

O embrião da atual Universidade Estadual de Feira de Santana (UEFS) foi a Faculdade de Educação de Feira de Santana, instalada em 1968, com base no decreto do então governador do Estado da Bahia, Luiz Viana Filho. Em 1970, por meio da Lei Estadual no 2.784, de 24 de janeiro de 1970, foi criada a Fundação Universidade de Feira de Santana (FUFS). Esta fundação foi organizada de acordo com projeto elaborado pelo Centro de Estudos Interdisciplinares para o Setor Público (ISP), ligado à Universidade Federal da Bahia, tendo seu plano estrutural fundamentado nos dois princípios básicos da Reforma Universitária: a não duplicação de meios para fins idênticos ou equivalentes, e a indissociabilidade de ensino, pesquisa e extensão. 
Em 31 de maio de 1976 a UEFS foi instalada, com a oferta de oito cursos, sendo cinco bacharelados (Administração; Ciências Contábeis; Ciências Econômicas; Enfermagem; e Engenharia de Operações - Modalidade Construção Civil); uma Licenciatura de $1^{\circ}$ e $2^{\circ}$ graus em Letras (Francês e Inglês); e duas Licenciaturas Plenas (Ciências, com habilitação em Matemática, Biologia e em Ciências $1^{\circ}$ grau; e Estudos Sociais, com habilitação em Educação Moral e Cívica e em Estudos Sociais $1^{\circ}$ grau) (UEFS, 2015a).

A estrutura administrativa e operacional escolhida, entre as opções de integração oferecidas pela Lei, foi a que se baseava na articulação interdepartamental com a Administração Superior, sem que houvesse a possibilidade de coordenação administrativa em nível intermediário (faculdades, institutos ou centros). O curso de Ciências Contábeis está vinculado ao Departamento de Ciências Sociais Aplicadas (DCIS), juntamente com os cursos de Administração, Economia e Direito, cada qual com o seu colegiado.

Segundo seu Plano de Desenvolvimento Institucional (PDI), até 1995 a implantação de projetos de pesquisa foi incipiente, porque era necessário, primeiro, capacitar os seus quadros docente e técnico-administrativo. Para tanto, foram definidas e iniciadas metas, como: a) implantação de Programa de Capacitação Docente; b) criação de novos cursos, para ampliar os domínios do conhecimento e permitir maior acesso ao ensino superior; e c) incentivo à criação de projetos de pesquisa e fortalecimento dos Programas de Extensão Universitária. Até 2007, a UEFS também se ressentia de maior atuação no que tange à internacionalização. Para tanto, foi criada a Assessoria Especial de Relações Institucionais (AERI), em substituição à Assessoria Especial de Intercâmbio (UEFS, 2015b).

Em seu PDI 2011-2015, a universidade apresenta sua missão, visão e objetivos (UEFS, 2015b).

a) Missão: Produzir e difundir o conhecimento, assumindo a formação integral do homem e de profissionais cidadãos, contribuindo para o desenvolvimento regional e nacional, promovendo a interação social e a melhoria da qualidade da vida, com ênfase na região do semiárido.

b) Visão: Manter sua condição de universidade pública, gratuita e autônoma visando credibilidade enquanto instituição de ensino de graduação e pós-graduação de qualidade, com linhas de pesquisa consolidadas, produção científica relevante, 
atividades extensionistas transformadoras da sociedade na qual está inserida, e com inserção internacional institucionalizada, além de manter a sua posição de excelência em estudos do semiárido.

c) Objetivos: i) ministrar educação geral de nível superior, formando cidadãos responsáveis, empenhados na solução democrática dos problemas nacionais; ii) preparar profissionais altamente qualificados em todos os ramos do saber, capazes de promover o progresso social pela utilização dos recursos da técnica e da ciência; iii) congregar mestres, cientistas e artistas e lhes assegurar os meios necessários para se devotarem à ampliação do conhecimento, ao cultivo das artes e sua aplicação a serviço do homem; iv) promover o desenvolvimento das ciências, das letras, das artes e da tecnologia pelo ensino, a pesquisa e a extensão; e v) servir de instrumento de promoção do desenvolvimento cultural, social e econômico da região de Feira de Santana.

No primeiro semestre de 2015, a UEFS ofertava 27 cursos regulares de graduação, sendo 14 bacharelados e 13 licenciaturas, em diversas áreas do conhecimento (UEFS, 2015c). Existem 16 mestrados, dos quais um é profissional e outro é realizado em convênio com a UnB. Há também cinco doutorados, dos quais dois em convênio: um com a UFBA e outro, multi-institucional, com a UFBA e a UNIFACS (UEFS, 2015d).

A UEFS realiza suas atividades em um único campus, no qual estão localizados os sete módulos para desenvolvimento de atividades acadêmicas e os Centros Administrativos I, II e III. A UEFS conta ainda com um Centro de Informática, um Centro de Educação Básica, um Parque Esportivo, o Prédio da Biblioteca, uma Creche, Residência Universitária, Observatório Astronômico, Estação Climatológica, Centro de Treinamento Xavantes, Sede de Educação Ambiental, Centro Universitário de Cultura e Artes, Museu Casa do Sertão e seis Clínicas Odontológicas.

No primeiro semestre de 2015, o curso de Ciências Contábeis do DCIS/UEFS contava com 376 alunos ativos, todos do período noturno, segundo dados do Sistema Sagres Educação do DCIS/UEFS, fornecidos pelo Colegiado de Graduação da entidade. No segundo semestre de 2015, havia, neste curso, 24 docentes, sendo cinco adjuntos (doutores), doze assistentes (mestres), três auxiliares (especialistas) e quatro substitutos (mestres). Desses 24, apenas quatro trabalhavam sob o Regime de Dedicação Exclusiva (DE) (no primeiro semestre só 
havia um docente, professor assistente, com o regime de DE), 22 sob o Regime de Tempo Parcial de 40 horas, e um sob o Regime de Tempo Parcial de 20 horas $^{18}$.

\subsubsection{Resultados das Entrevistas com os docentes do DCIS/UEFS}

Nesta subseção são apresentados os resultados obtidos a partir das entrevistas em profundidade com os oito docentes que, voluntariamente, aceitaram participar da pesquisa. Da mesma forma que na FEA/USP, os nomes dos docentes foram omitidos por motivo de confidencialidade.

O primeiro ano (2012) do programa de doutorado interinstitucional (Dinter) do autor desta tese foi realizado nas dependências da UEFS, o que lhe propiciou conhecer os aspectos físicos da universidade, como salas, prédios, laboratórios e biblioteca. Também lhe deu a oportunidade de vivenciar o relacionamento com professores, o Pró-reitor de Administração e Finanças e técnicos da secretaria de pós-graduação. Estes contatos foram ampliados durante o período de visitas para o trabalho de pesquisa no campo empírico.

Conforme descrito na seção 3.4, foi elaborado um DSC pelo autor, baseado na visão coletiva dos oito docentes entrevistados, sobre a retrospectiva histórica do curso de Ciências Contábeis do DCIS/UEFS.

O curso de Ciências Contábeis da UEFS foi criado em 1976, vinculado ao DCIS (Departamento de Ciências Sociais Aplicadas), que abrange os cursos de Ciências Contábeis, Ciências Econômicas, Administração e Direito. Há duas fases distintas nessa retrospectiva: a inicial, que perdurou até 2005; e a de 2006 até os dias atuais, quando eu e alguns colegas estávamos retornando do doutorado. Na fase inicial a união era muito forte entre a coordenação, docentes e até os próprios alunos, creio que entusiasmados em poder estudar em uma IES pública em Feira de Santana. Havia outras características: a universidade era menor, facilitando a integração e o coleguismo entre seus membros; havia uma administração diferenciada que facilitava e dinamizava mais as coisas em uma série de contextos; não havia problemas financeiros; e a relação com o governo do Estado era mais direta.

\footnotetext{
18 Segundo a UEFS (2015e), no regime de dedicação exclusiva os docentes só podem ter vinculação à universidade (dedicando-se às atividades de ensino, pesquisa e extensão). No regime de 40 horas, os docentes devem ter esse tempo dedicado ao ensino e pesquisa, porém limitados ao mínimo de três e máximo de quatro turmas semanais (total de 16 horas). No de 20 horas, o docente deve ter esse tempo dedicado apenas ao ensino, porém limitado ao mínimo de duas turmas e máximo de três, desde que não exceda 10 horas semanais.
} 
Havia também outro aspecto no início: devido à carência de docentes na época, a UEFS fez, durante um curto período, uma seleção interna entre os egressos do curso com aptidão para o ensino. Foi assim que eu e outros colegas ingressamos como docentes, apenas com a graduação. Depois fizemos especialização, mestrado, e alguns, até o doutorado. Confesso que aprendi muito na minha vivência como docente na interação com os alunos e no processo ensino-aprendizagem daqui, mas eu e outros colegas também tivemos experiências de ensino em turmas de IES privadas em Feira de Santana e outras cidades, até de outros estados.

Embora não tenhamos na UEFS figuras exponenciais no campo do desenvolvimento da Contabilidade no Brasil, nós podemos destacar alguns docentes-ícones que prestaram uma grande contribuição, deixando muitos seguidores que hoje atuam como docentes do curso. Esses chamados docentes-ícones são: Jorge de Jesus Almeida, pioneiro desde 1976, José Maria Dias Filho (atualmente em outra instituição), Ariosvaldo Ailton S. Moreira e Antônio Carlos Ribeiro da Silva, entre outros.

Na segunda fase, com a expansão, mais precisamente a partir de 2006, encontramos uma universidade bem distinta, com pessoas diferentes, pelo menos no nosso departamento e no nosso curso. A gestão estava dispersa, difusa e afastada das questões acadêmicas, o que permanece até hoje. Devido à referida expansão e também a problemas políticos com o Estado, a UEFS teve sua situação financeira muito agravada, interferindo bastante na sua utópica autonomia. Por exemplo, alguns docentes já terminaram o doutorado há mais de seis anos, mas apesar de terem cumprido os trâmites necessários à promoção vertical para professor-adjunto, ainda continuam como professores-assistentes.

O quadro de docentes do curso está envelhecido e apenas um deles possui dedicação integral. Os demais estão em regimes de 40 ou 20 h. Hoje percebo mais a importância e empenho assumidos pelo DCIS em não deixar os alunos, de qualquer semestre, sem professor e sem aulas durante o período letivo, devido ao afastamento de docentes para qualificação em doutorados. A carência de docentes é suprida por docentes substitutos. Há uma queda na motivação, tanto dos alunos quanto dos docentes, que pode ser notada pelo número de salas vazias e na conduta de alguns docentes.

A reitoria atual passou por dois mandatos, e em 2011 houve uma grande vitória, que foi a realização do Dinter com a FEA/USP. Outro evento relevante foi o que nós, docentes e estudantes, conquistamos por intermédio de um Senador do estado: uma dotação orçamentária para a construção do prédio da Pós-Graduação, mas a conversão dessa dotação em recursos passa pelos trâmites morosos da política. Creio que é uma tarefa difícil para uma entidade pública mudar o contexto institucional e aperfeiçoá-lo. Apesar disso, há um aspecto positivo na COA da UEFS: embora ela seja uma IES nova, se comparada a outras instituições públicas estaduais ou mesmo federais, ela é muito audaciosa porque se arrisca; há um grupo de docentes que luta de forma contínua por um posicionamento mais agressivo no cenário regional e nacional.

Como possui um único Campus, a UEFS, potencialmente, propicia mais proximidade entre a gestão, nas pessoas do reitor, pró-reitores e quadros de docentes e técnicos, e os próprios discentes, ou seja, há muito mais opções de se aproximar do reitor ou pró-reitor para tentar persuadi-lo com ideias novas ou o uso de inovações para gerir e melhorar o 
curso. No entanto, tudo depende da burocracia e da morosidade característica da administração pública.

Há elementos relevantes nesse DSC dos docentes, que surpreendem pela descrição analítica da realidade vivenciada no seu cotidiano, mas traz elementos distintos dos conteúdos discursivos históricos disponíveis nos portais da UEFS. Diante do exposto, parece que o curso de Ciências Contábeis vem passando por um ciclo restritivo e adverso.

Assim como realizado na FEA/USP, as respostas dos docentes à questão da pesquisa foram desdobradas nas dimensões missão, adaptabilidade externa, integração interna e consistência, apresentadas em quatro tabelas, uma para cada dimensão. Os DSC da dimensão missão, vinculados às respectivas categorias, de acordo com os atributos ou operadores da técnica do DSC, estão apresentados na Tabela 27.

Tabela 27

DSC dos docentes do curso no DCIS/UEFS quanto à missão do curso

Questão 1: Qual o atual estágio da COA do curso de ciências contábeis do DCIS/UEFS, relativo à missão? (abrange visão; orientação estratégica e intenção; e metas e objetivos)

Categorias

Missão: O sujeito coletivo diz que a missão do curso de Ciências Contábeis não é clara, mas deduz que ela visa formar cidadãos críticos para o mercado profissional regional e nacional, mas principalmente para a região de Feira de Santana.
Discurso do Sujeito Coletivo (DSC)

Embora exista uma missão no $P P P^{a}$ do curso na UEFS, esta não é seguida, porém creio que seja a de qualificar o corpo docente e, por consequência, as atividades de pesquisa e produção científica para a formação de profissionais em Contabilidade críticos, reflexivos, comprometidos com a profissão e capacitados para atuar no mercado de trabalho.

Creio que a missão do curso está voltada para formar cidadãos críticos, comprometidos com a profissão $e$ aptos a contribuir para a sociedade, mas não existem metas e objetivos para controle e acompanhamento, por falta de planejamento estruturado na UEFS.

Está implícito que a missão é formar cidadãos comprometidos com a profissão e aptos para o mercado profissional regional e nacional, visando buscar sempre uma integração com a sua comunidade, sobretudo a mais próxima, priorizando sua identificação com a região de Feira de Santana. 
\begin{tabular}{|c} 
Discurso do Sujeito Coletivo (DSC) \\
Embora a UEFS tenha a sua administração superior
\end{tabular} totalmente estruturada e formal, não há uma liderança bem definida, e as atividades do cotidiano são conduzidas de forma muito dispersa, sem acompanhamento e controle de metas e objetivos, porque estes não existem. Os únicos planos existentes são aqueles que constam dos documentos formais do projeto do curso, os quais nunca foram seguidos. Não

Gestão: O sujeito coletivo comenta que, como não há planejamento, liderança nem gestão do curso no DCIS/UEFS, não existem metas e objetivos para serem controlados e acompanhados. há uma orientação estratégica da gestão e nem um planejamento estruturado para o curso.

É preciso que a direção da UEFS faça uma reflexão sobre como está o curso de Contábeis, quais são os pontos fracos e fortes e o que pode ser melhorado, para que se criem condições para que o curso desenvolva maior nível de qualificação e visibilidade.

A coordenação do colegiado do curso trata, no cotidiano, apenas de assuntos academicos, principalmente com discentes e, eventualmente, com docentes, que têm muita liberdade para desenvolver suas atividades. Embora esteja formalmente vinculado ao DCIS, não há interação entre ambos, pois este parece difuso e burocrático.

O Curso de Contábeis da UEFS, desde a sua gênese, teve docentes que eram profissionais de mercado, o que contribuiu para seus traços culturais serem tecnicistas, profissionais e voltados estritamente para o mercado e a

Curso de Ciências Contábeis: $O$ sujeito coletivo indica algumas características do curso de Ciências Contábeis da UEFS, entre elas um traço cultural profissional, cartorial e não acadêmico. sociedade, o que permanece até hoje.

Infelizmente não existe o caráter acadêmico no curso, cujos docentes basicamente dão suas aulas e os alunos, ao final do curso, recebem o seu diploma. É preciso uma renovação imediata e contínua do nosso quadro de docentes, além de redefinir a lógica tecnicista $e$ profissional do curso para desenvolver o pensamento crítico-reflexivo nos alunos, para que estes possam ser agentes de mudança, pensadores e formadores de opinião.

\footnotetext{
Nota. ${ }^{\text {a }}$ Projeto Político Pedagógico
}

Com base na mesma linha dos referenciais teóricos e dos argumentos apresentados na seção 4.1.2, é possível deduzir que as 'crenças e valores expostos', ou seja, os juízos de valor da dimensão em análise podem ser percebidos a partir das descrições contidas nas categorias da Tabela 27: Missão; Gestão; e Curso de Ciências Contábeis.

O terceiro nível de cultura na teoria de Schein (2009), suposições básicas, ou valores, na concepção de Hofstede (2003), pode ser deduzido de trechos dos DSC da dimensão missão, respectivamente, nas três categorias já citadas. 
Embora exista uma missão no PPP do curso na UEFS, esta não é seguida, porém creio que seja a de [...] formar cidadãos críticos [...] comprometidos com a profissão e aptos para o mercado profissional [...] regional e nacional, priorizando sua identificação com a região de Feira de Santana.

Embora a UEFS tenha sua administração superior totalmente estruturada e formal, não há uma liderança bem definida e as atividades do cotidiano são conduzidas de forma muito dispersa, sem acompanhamento e controle de metas e objetivos, porque estes não existem [...]. Não há uma orientação estratégica da gestão e nem um planejamento estruturado para o curso [...]. É preciso que a direção da UEFS faça uma reflexão sobre como está o curso de Contábeis, [...] o que pode ser melhorado, para que se criem condições para que o curso desenvolva um maior nível de qualificação e visibilidade. [...] A coordenação do colegiado [...] trata [...] apenas de assuntos acadêmicos, principalmente com discentes [...]. Embora esteja formalmente vinculado ao DCIS, [...] não há interação entre ambos, pois este parece difuso e burocrático.

O Curso de Contábeis da UEFS, desde a sua gênese, teve docentes que eram profissionais de mercado, o que contribuiu para seus traços culturais serem tecnicistas [...] e voltados estritamente para o mercado [...], o que permanece até hoje [...]. Infelizmente não existe o caráter acadêmico no curso, cujos docentes, basicamente, dão suas aulas e os alunos, ao final do curso, recebem o seu diploma. É preciso uma renovação imediata e contínua do nosso quadro de docentes, além de redefinir a lógica tecnicista e profissional do curso para desenvolver o pensamento crítico-reflexivo nos alunos, para que estes possam ser agentes de mudança, pensadores e formadores de opinião.

De acordo com Denison et al. (2012), em sua definição sobre a missão organizacional, esta, uma vez bem definida, fornece propósito e um conjunto de metas para a organização. Hofstede (2003) destaca a missão como um dos elementos essenciais para a diagnose periódica da organização, em sua busca de melhoria contínua. De acordo com o DSC dos docentes, há indicações de que o curso de Ciências Contábeis do DCIS/UEFS não apresenta propósitos bem definidos ou uma orientação estratégica (formal ou informal).

Ademais, embora os docentes apontem que há uma missão no PPP, o autor desta tese não conseguiu encontrá-la nos documentos formais do curso. Ainda assim, eles tentaram formular uma missão consoante o seu entendimento, porém percebe-se que eles sentem a ausência de uma liderança definida, e comentam que as atividades se sucedem de forma difusa e muito dispersa. Talvez isto decorra do tipo de estrutura administrativa da UEFS, que exclui a possibilidade de coordenação administrativa em nível intermediário, ou seja, que envolva os órgãos de ensino, departamentos e colegiados, entre outros. Este fato parece explicar, em parte, o distanciamento entre a gestão e o colegiado. 
$\mathrm{Na}$ literatura empírica, Tierney (1988) indica, em seus achados, que uma das causas dos bons resultados da IES pesquisada é que os docentes, técnicos e alunos eram bem informados pela liderança, embora informalmente, dos planos da IES. Este achado parece explicar parcialmente o porquê da situação crítica do curso do DCIS/UEFS, com relação à missão. Já Denison e Mishra (1995) concluíram que as características de missão e consistência eram indicadoras de visão, direção e integração, sendo preditoras mais adequadas de resultados positivos, o que parece também não ter sido o caso do curso do DCIS/UEFS.

Os DSC da dimensão adaptabilidade externa, vinculados às suas respectivas categorias, estão apresentados na Tabela 28.

Tabela 28

DSC dos docentes do curso do DCIS/UEFS quanto à adaptabilidade externa

Questão 2: Qual o atual estágio da COA do curso de Ciências Contábeis do DCIS/UEFS, relativo à adaptabilidade externa? (abrange criação da mudança; foco no cliente [sociedade, mercado e estudantes]; e aprendizagem organizacional)

\begin{tabular}{|c|c|}
\hline Categorias & Discurso do Sujeito Coletivo (DSC) \\
\hline $\begin{array}{l}\text { Ações frente às mudanças: } O \text { sujeito coletivo diz } \\
\text { que geralmente as ações de atualização frente às } \\
\text { mudanças, incluindo a revisão da grade curricular e } \\
\text { outros eventos, como seminários e palestras com } \\
\text { docentes de fora, foram decorrentes da iniciativa de } \\
\text { docentes da instituição que contou, às vezes, com o } \\
\text { apoio da gestão. }\end{array}$ & $\begin{array}{l}\text { O departamento tem apoiado a iniciativa conjunta de } \\
\text { alunos, incentivados pelos docentes, de realizar } \\
\text { eventos, trazendo profissionais de fora para falar } \\
\text { sobre temas atuais e as principais mudanças que } \\
\text { afetam a profissão contábil. Muitos docentes, } \\
\text { mormente os da área contábil-financeira, trazem } \\
\text { temas atuais do mercado profissional para a sala de } \\
\text { aula. } \\
\text { Atualmente estamos atualizando a grade curricular, } \\
\text { tanto nos conteúdos, em função das mudanças, com a } \\
\text { implantação das normas internacionais, quanto na } \\
\text { redução da duração do curso de cinco para quatro } \\
\text { anos, para igualar aos demais cursos no pais, porém } \\
\text { cuidando para manter o equilibrio entre teoria e } \\
\text { prática. } \\
\text { Hoje temos o desafio do EaD convivendo com o } \\
\text { ensino presencial. Creio que é possivel equilibrar } \\
\text { esses recursos ao invés de usá-los isoladamente, } \\
\text { para potencializar o processo ensino-aprendizagem. } \\
\text { Embora a UEFS seja nova se comparada a outras } \\
\text { IES públicas estaduais ou federais, ela às vezes se } \\
\text { arrisca, a partir da iniciativa de docentes que } \\
\text { buscam uma melhor posição da instituição no } \\
\text { cenário regional e nacional. O Dinter foi um exemplo } \\
\text { desse esforço, que resultou em convênio com a } \\
\text { FEA/USP e IES públicas parceiras na Bahia. }\end{array}$ \\
\hline
\end{tabular}


Continuação da Tabela 28

\begin{tabular}{l}
\hline Categorias \\
\hline \\
COA do curso na UEFS: O sujeito coletivo trata de \\
alguns aspectos da cultura organizacional da \\
universidade quanto ao curso de Ciências Contábeis, \\
indicando que há ausência de liderança e gestão, a \\
qual tem prejudicado o curso, embora tenha havido \\
apoio eventual a algumas ações audaciosas de \\
iniciativa dos docentes (Mestrado e Dinter).
\end{tabular}

Discurso do Sujeito Coletivo (DSC)

No início a UEFS não tinha concorrência, e mesmo com o crescente número de IES privadas a gestão nunca se preocupou com isso, o que talvez explique, parcialmente, o porquê da perda gradativa de alunos para a concorrência, e também a queda nos niveis de qualidade dos alunos e do ensino. Portanto, nosso curso está exposto a grandes desafios quanto às inovações e tecnologias trazidas pelas mudanças.

A UEFS não possui autonomia financeira e tudo é centralizado na Reitoria. As unidades acadêmicas cuidam somente de assuntos ligados ao curso e não têm qualquer poder de gestão nem desfrutam de nenhum reconhecimento.

Apesar das desvantagens de o curso ser noturno $e$ não ter uma direção atuante, boa parte dos docentes busca apoio de órgãos externos para se qualificar, visando aperfeiçoar o curso e dinamizar a pesquisa e produção científica, quase inexistente há dez anos. Outro aspecto: por falta de reconhecimento e compensação, ninguém quer assumir as atribuições de coordenação do colegiado, que são limitadas $e$ conduzidas de forma inercial, da mesma forma de outros que ocuparam esta função anteriormente.

Acredito que os docentes, em geral, não procuram se integrar com os discentes na melhoria do processo ensino-aprendizagem. Apenas uma minoria procura escutar os alunos e negociar a condução do conteúdo.

Ensino-aprendizagem: O sujeito coletivo diz que o curso vem decaindo em qualidade e motivação, com baixa integração entre seus membros, assemelhandose a cursos de baixa qualidade em IES privadas, com a vantagem de não precisar pagar mensalidades.

Percebo ainda, de forma geral, uma queda na motivação dos alunos ao longo do tempo, que pode ser uma das causas para a redução gradativa do número de ingressantes no curso, além da queda nos níveis de qualidade do ensino. Outro aspecto crítico é que, embora o curso seja de uma IES pública, parece que houve uma importação da cultura das IES privadas no mau sentido, ou seja, a única vantagem que os alunos do curso da UEFS têm sobre os alunos das IES privadas é que eles não precisam pagar mensalidades.

Na linha dos comentários anteriores, referente a esta etapa, as 'crenças e valores expostos' da dimensão em análise estão contidas nas descrições das categorias da Tabela 28: Ações frente às mudanças; COA do curso na UEFS; e Ensino-aprendizagem.

As suposições básicas, na dimensão adaptabilidade externa, foram extraídas, em síntese, a partir de trechos dos DSC contidos na Tabela 28, respectivamente nas categorias citadas. 
O departamento tem apoiado a iniciativa conjunta de alunos, incentivados pelos docentes, de realizar eventos, trazendo profissionais de fora para falar sobre temas atuais [...] que afetam a profissão contábil [...]. Atualmente estamos atualizando a grade curricular [...] com a implantação das normas internacionais, [...] na redução da duração do curso de cinco para quatro anos [...]. Hoje temos o desafio do EaD convivendo com o ensino presencial. Creio que é possível equilibrar esses recursos ao invés de usá-los, isoladamente, para potencializar o processo ensino-aprendizagem. [...] Embora a UEFS seja nova se comparada a outras IES públicas [...], ela às vezes se arrisca, a partir da iniciativa de docentes que buscam uma melhor posição da UEFS no cenário regional e nacional. O Dinter foi um exemplo desse esforço, que resultou em convênio com a FEA/USP e IES públicas parceiras na Bahia.

No início a UEFS não tinha concorrência, e mesmo com o crescente número de IES privadas a gestão nunca se preocupou com isso, o que talvez explique parcialmente o porquê da perda gradativa de alunos [...] e a queda nos níveis de qualidade dos alunos e do ensino. [...] A UEFS não possui autonomia financeira e tudo é centralizado na Reitoria. As unidades acadêmicas cuidam somente de assuntos ligados ao curso e não têm qualquer poder de gestão nem desfrutam de nenhum reconhecimento. [...] outro aspecto: por falta de reconhecimento e compensação, ninguém quer assumir as atribuições de coordenação do colegiado, que são limitadas e conduzidas de forma inercial, da mesma forma de outros que ocuparam esta função anteriormente.

Acredito que os docentes, em geral, não procuram se integrar com os discentes na melhoria do processo ensino-aprendizagem. Apenas uma minoria procura escutar os alunos e negociar a condução do conteúdo. [...] percebo ainda, de forma geral, uma queda na motivação dos alunos ao longo do tempo, que pode ser uma das causas para a redução gradativa do número de ingressantes no curso, além da queda nos níveis de qualidade do ensino. [...] outro aspecto crítico é que embora o curso seja de uma IES pública, parece que houve uma importação da cultura das IES privadas no mau sentido, ou seja, a única vantagem que os alunos do curso da UEFS têm sobre os alunos das IES privadas é que eles não precisam pagar mensalidades.

Denison et al. (2012) comentam que esta dimensão geralmente traduz o entendimento que as entidades adaptáveis possuem sobre as mudanças do ambiente externo, rapidamente convertendo-as em ações. Contudo, acrescentam que entidades com propósito e direção já rigorosamente definidos são as menos capazes de se adaptar e, portanto, com maiores dificuldades para mudar. Schein (2009) menciona que a organização deve desenvolver meios e critérios, de forma a utilizá-los para mensurar quão bem o grupo trabalha para atingir suas metas.

Ao que parece, com base apenas nas manifestações dos docentes, expressadas nos trechos extraídos dos seus DSC, tudo indica que eles percebem graves restrições organizacionais que impedem o curso de adaptar-se às mudanças. Essas duas primeiras dimensões, na teoria de 
Denison et al. (2012), são as que mantêm a organização em sintonia com o seu ambiente externo. Não é difícil perceber que, na visão dos docentes, o curso parece estar desconectado da realidade exterior, o que poderia contribuir para a sua obsolescência, caso a gestão, em articulação com o DCIS e o colegiado, não promovam ações de melhoria.

Conforme se pode observar, as ações do curso no DCIS/UEFS parecem muito frágeis, em relação ao dinâmico ambiente externo. Eventualmente ocorrem palestras com profissionais de outras cidades ou estados, porém em número cada vez menor. Ainda se está pensando em equilibrar o EaD com a educação presencial. Não há indicação de ações da gestão face às evidências de aumento crescente de cursos em IES privadas na região, perda gradativa de alunos e queda nos níveis de qualidade do ensino. Há indícios de que não há engajamento e integração entre os docentes e a coordenação do curso para tentar melhorar a situação. Há ainda uma forte crítica em um trecho final do DSC que diz: "parece que houve uma importação da cultura das IES privadas no mau sentido, ou seja, a única vantagem que os alunos do curso da UEFS têm sobre os alunos das IES privadas é que na UEFS eles não precisam pagar mensalidades".

Quanto ao aspecto mais profissional do curso, como já relatado anteriormente para a FEA/USP, Hofstede (2003) sustenta que esta é uma característica dos países com elevado controle de incerteza e sistema de codificação mais detalhado (Code Law), em que as informações são as mesmas para os acionistas e o físco, ao contrário de países com baixo controle de incerteza, nos quais o regime de codificação é o Common Law (Estados Unidos e outros). Nos países que adotam o regime Code Law (caso do Brasil), o autor aponta que a profissão de contabilista tende a ocupar uma posição inferior.

Com base nos comentários dos docentes, reforça-se o entendimento de que o curso de Ciências Contábeis no DCIS/UEFS parece estar desconectado da realidade exterior e sem diretrizes bem definidas pela gestão, o que dificulta um direcionamento mais claro. Entretanto, deve-se apontar que, ao menos nos documentos formais da UEFS, existe um objetivo social geral bem definido, descrito na seção 4.2.1.

Os DSC da dimensão integração interna, vinculados às respectivas categorias, estão apresentados na Tabela 29. 
Tabela 29

DSC dos docentes do curso do DCIS/UEFS quanto à integração interna

\begin{tabular}{l} 
Questão 3: Qual o atual estágio da COA do curso \\
integração interna? (abrange orientação da equipe; \\
Categorias \\
\hline \\
Ensino-aprendizagem: O sujeito coletivo trata de \\
características do processo de ensino-aprendizagem \\
do curso de Ciências Contábeis na UEFS, e mostra \\
que este processo do curso apresenta sinais de \\
enfraquecimento, tanto nos alunos quanto nos \\
docentes.
\end{tabular}

Não há incentivo por parte da gestão do curso no DCIS/UEFS para aperfeiçoamento de metodologias dos docentes, e a maioria ainda possui uma visão muito cartesiana.

Excetuando os poucos docentes que levam a sério a atividade acadêmica, a visão predominante da COA do curso é de que ele é uma linha de produção em série, no mau sentido, para formar profissionais para o mercado e profissionais que atuam como docentes.

O curso não tem estrutura para liberar docentes para qualificação porque isto gera certa desmotivação nos alunos, que imaginavam fazer as disciplinas com aqueles mestres [afastados] já reconhecidos por suas características no ensinoaprendizagem. Embora haja uma ação rápida na contratação de substitutos, ocorre algum esvaziamento das salas de aulas.

Um problema atual nos cursos de Contabilidade em IES públicas no Brasil é que a maioria dos docentes possui apenas formação acadêmica, que se reflete em aulas mais teóricas do que práticas, as quais a profissão tanto exige para atender o mercado e a sociedade.

Atualmente temos um quadro envelhecido de docentes, alguns desmotivados, que se reflete no cotidiano das salas de aula, formando "contadores" dentro de uma lógica tecnicista. Por essa razão, geralmente os egressos não têm pensamento críticoreflexivo e capacidade para pensar a contabilidade da entidade e os fenômenos que afetam o seu tecido patrimonial, ou seja, a sua capacidade de geração de riqueza por meio dos comportamentos e decisões de seus agentes. 
Continuação da Tabela 29

\begin{tabular}{l} 
Categorias \\
\hline \\
Engajamento docente: O sujeito coletivo afirma que \\
o processo de engajamento e integração dos docentes \\
com o curso, coordenação e gestão, diante das \\
mudanças ao longo do tempo, era mais intenso no \\
início do curso, mas hoje é mínimo e basicamente \\
informal ou acidental.
\end{tabular}

\begin{abstract}
Discurso do Sujeito Coletivo (DSC)
No início, havia maior integração entre os docentes, mas hoje esse aspecto é mínimo e informal, restrito a encontros casuais no lanche e café; o próprio colegiado não tem agenda prévia para reuniões, as quais acontecem, em geral, quando há algum problema para resolver. Aqui, os docentes agem isolados, com liberdade na condução de suas disciplinas e sem cobranças. Não percebo nenhuma sinalização ou orientação de que o curso de Ciências Contábeis esteja se engajando e mobilizando para se adequar às mudanças do ambiente externo.
\end{abstract}

Em 1997, por nossa iniciativa, conseguimos o apoio do então coordenador do colegiado e da gestão para fazer um mestrado em Contabilidade em Salvador, mediante convênio com uma instituição baiana privada. Ao longo de cinco anos, nos tornamos 11 mestres em Contabilidade. Isto intensificou as atividades de pesquisa e a produção científica na UEFS, que passou a participar de quase todos os eventos e congressos de Contabilidade do país.

Embora a gestão tenha apoiado, eventualmente, a qualificação e aperfeiçoamento dos docentes, todas as iniciativas se originaram nos próprios docentes, ou seja, nunca tivemos um programa regular de qualificação docente que contemplasse a pósgraduação e cursos rápidos de atualização contínua, tão necessários ao trabalho do contador.

Recentemente, também por iniciativa dos docentes do curso, encampada pela gestão, foi realizado algo audacioso: um convênio com a FEA/USP e IES públicas associadas baianas para a realização de um Dinter, que está em andamento.

No início, quando a UEFS era menor, o próprio ambiente facilitava o processo de integração entre gestão, docentes e discentes. Havia também uma gestão distinta da atual, sem problemas financeiros e com um contato mais estreito com o governo do Estado, o que facilitava e dinamizava mais as coisas, de forma geral.

Percebemos, atualmente, na liderança e gestão superior, em geral, a intenção de busca da excelência, mas esta não tem se convertido em realidade devido a fatores fora do controle da direção da UEFS, ou seja, não há autonomia da IES para fazer um planejamento estruturado e conduzir esse plano.

$\mathrm{Na}$ linha dos comentários anteriores, especificamente sobre esta etapa, a dimensão integração interna contém as 'crenças e valores expostos', descritos nas suas categorias: Ensino-aprendizagem; Engajamento docente; e Liderança e gestão. 
As suposições básicas, segundo Schein (2003), ou os valores, de acordo com Hofstede (2003), da dimensão da tabela em análise, foram extraídos de trechos dos DSC da Tabela 29, respectivamente, nas três categorias citadas.

Apesar da existência de docentes qualificados na ativa [...], o curso hoje mostra sinais de enfraquecimento quanto à união e integração dos docentes, com redução dos níveis de qualidade do ensino e da quantidade e qualidade dos alunos, associados à falta de liderança e direção. [...] não há incentivo [...] para aperfeiçoamento de metodologias dos docentes [...]. Excetuando os poucos docentes que levam a sério a atividade acadêmica, a visão predominante da COA do curso é de que ele é uma linha de produção em série, no mau sentido, para formar profissionais para o mercado. [...] $\mathrm{O}$ curso não tem estrutura para liberar docentes para qualificação porque isto gera certa desmotivação nos alunos, que imaginavam fazer as disciplinas com aqueles mestres [afastados] já reconhecidos por suas características no ensino-aprendizagem [...]. Atualmente temos um quadro envelhecido de docentes, alguns desmotivados, que se reflete no cotidiano das salas de aula, formando "contadores" dentro de uma lógica tecnicista. [...] os egressos não têm pensamento crítico-reflexivo e capacidade para pensar a contabilidade da entidade e os fenômenos que afetam o seu tecido patrimonial.

No início, havia maior integração entre os docentes, mas hoje esse aspecto é mínimo e informal $[. .$.$] ; o próprio colegiado não tem agenda prévia para reuniões, as quais$ acontecem, em geral, quando há algum problema para resolver. [...]. Não percebo [...] sinalização [...] de que o curso [...] esteja se engajando e mobilizando para se adequar às mudanças do ambiente externo. [...]. Em 1997, por nossa iniciativa, conseguimos o apoio [...] da gestão para fazer um mestrado em contabilidade [...]. Ao longo de cinco anos, nos tornamos 11 mestres em Contabilidade. Isto intensificou as atividades de pesquisa e a produção científica na UEFS, que passou a participar de quase todos os eventos e congressos de Contabilidade do país. [...]. Recentemente, também por iniciativa dos docentes do curso, e encampada pela gestão, foi obtido algo audacioso: um convênio com a FEA/USP e IES públicas associadas baianas para realização de um Dinter, que está em andamento.

No início, quando a UEFS era menor, o próprio ambiente facilitava o processo de integração entre gestão, docentes e discentes. Havia também uma gestão distinta da atual, sem problemas financeiros e com um contato mais estreito com o governo do Estado, o que facilitava e dinamizava mais as coisas de forma geral. [...]. Percebemos, atualmente, na liderança e na gestão superior, em geral, a intenção de busca da excelência, mas esta não tem se convertido em realidade devido a fatores fora do controle da direção da UEFS, ou seja, não há autonomia da IES para fazer um planejamento estruturado e conduzir esse plano.

Nos trechos do DSC percebe-se novamente a repetição de sinais de enfraquecimento nos níveis de qualidade do ensino, dos docentes e dos alunos. Parece, a julgar pelo que está exposto, que o curso vem sendo cada vez menos procurado pelos estudantes. Os docentes 
registram ainda a diminuição e quase acidentalidade dos encontros e integração entre eles, destacando que não há indícios de ações de direcionamento para o seu engajamento, frente às mudanças externas e fazem críticas à gestão pela falta de direção e liderança. Este quadro é bastante diverso daquele descrito por Denison et al. (2012), os quais sustentam que na dimensão envolvimento (denominada por Schein (2009) de integração interna) os membros que compõem a organização devem estar fortemente comprometidos com suas atividades operacionais e possuir, além disso, a consciência de que suas atribuições estão diretamente ligadas aos objetivos organizacionais.

Há ainda uma analogia metafórica do curso de Ciências Contábeis a uma linha de produção industrial em série, mas no sentido negativo do termo. Embora o DSC aponte que ainda há um potencial na liderança e gestão de se buscar a excelência, os resultados concretos não têm evidenciado esta busca, talvez devido a fatores fora do controle da direção que limitam a autonomia da UEFS como autarquia, vinculada à Secretaria de Educação do Estado da Bahia.

O curso viveu uma evolução positiva desde a criação até o seu apogeu, entre 1998 e 2006. Desde então, vem decaindo sistematicamente, de acordo com os DSC elaborados a partir dos depoimentos dos docentes e também de acordo com dados do INEP (2012, 2013, e 2015b). Os conceitos do curso de Ciências Contábeis do DCIS/UEFS, bem como sua classificação em relação às IES do estado da Bahia, vêm sofrendo uma queda sistemática de 2006 a 2012, conforme se pode comprovar pelos números apresentados na Tabela 30. Esta queda é ainda mais significativa quando se nota que, em 2012, 41 instituições foram avaliadas no Enade.

Tabela 30

Conceitos obtidos no Enade pelo curso de Ciências Contábeis do DCIS/UEFS na Bahia (2006-2012)

\begin{tabular}{ccc} 
ANOS & Conceito Enade & Classificação da UEFS \\
\hline $\mathbf{2 0 0 6}$ & 5 & $1^{\circ}$ \\
$\mathbf{2 0 0 9}$ & 3 & $14^{\circ}$ \\
$\mathbf{2 0 1 2}$ & 2 & $32^{\circ}$ \\
\hline
\end{tabular}

Nota. Fonte: Adaptado de INEP (2010, 2012 e 2013). Resultados do Enade.

Esses dados são uma evidência da queda abrupta dos níveis de qualidade do processo ensino-aprendizagem, de forma consistente com muitos DSC dos docentes. Entretanto, há um trecho do DSC que indica desatualização já que está em contradição com a evolução dos 
conceitos do curso no Enade: "Apesar de tudo isso, a UEFS ainda tem boa referência na Bahia devido ao desempenho dos alunos nos exames externos, sendo que no Enade ela geralmente tem ficado entre os dois primeiros lugares na Bahia" (trecho do DSC contido no $2^{\circ}$ parágrafo da categoria ‘Curso de Ciências Contábeis', na dimensão 'Consistência' - Tabela 31).

Na literatura empírica, os achados de Denison e Mishra (1995) indicam que as dimensões envolvimento (ou integração interna) e adaptabilidade externa são indicadoras de flexibilidade, abertura e capacidade de resposta, sendo fortes preditoras de crescimento. No caso, devido à característica pública da IES (DCIS/UEFS), há limitações claras para o envolvimento. Devido a esse aspecto, é compreensível a natureza crítica do seu estado atual.

Os DSC da dimensão consistência, vinculados às suas respectivas categorias, estão apresentados na Tabela 31 .

Tabela 31

DSC dos docentes do curso do DCIS/UEFS quanto à consistência

\begin{tabular}{|c|c|}
\hline \multicolumn{2}{|c|}{$\begin{array}{l}\text { Questão 4: Qual o atual estágio da COA do curso de ciências contábeis do DCIS/UEFS, relativo à } \\
\text { consistência? (abrange acordo e coordenação; valores fundamentais; e integração) }\end{array}$} \\
\hline Categorias & Discurso do Sujeito Coletivo (DSC) \\
\hline $\begin{array}{l}\text { COA do Curso na UEFS: O } \\
\text { sujeito coletivo diz que a COA do } \\
\text { curso é fragmentada, dispersa e } \\
\text { sem liderança, e que está meio } \\
\text { adormecida, com algumas ações } \\
\text { de preservação da cultura e } \\
\text { costumes da cidade, mas que ela } \\
\text { consegue às vezes ousar e } \\
\text { surpreender, obtendo vitórias } \\
\text { inusitadas. }\end{array}$ & $\begin{array}{l}\text { Há traços de uma COA do curso na UEFS, mas ela é fragmentada, difusa, } \\
\text { imprecisa e sem liderança. Não há um núcleo de docentes doutores com DE } \\
\text { e com dedicação integral ao curso, nem, também, um projeto para uma pós- } \\
\text { graduação. Se existe uma COA do curso na UEFS, ela está adormecida, } \\
\text { mas há a expectativa de que os docentes que estão afastados para o } \\
\text { doutorado, mormente os do Dinter, tragam renovação, novos métodos, } \\
\text { técnicas e programas, visando promover melhorias no curso. } \\
\text { Creio que a UEFS anda meio dispersa devido ao processo de travamento } \\
\text { financeiro, mas acredito que, mesmo assim, ainda há uma COA especifica } \\
\text { do curso na UEFS com um potencial latente. Um exemplo recente foi o } \\
\text { empenho e a vitória de ter realizado o Dinter com a FEA/USP, concorrendo } \\
\text { com outras instituições do Brasil. } \\
\text { É preciso que a gestão promova um programa de avaliação docente, no } \\
\text { qual sejam apreciadas metodologias mais adequadas à melhoria do } \\
\text { processo ensino-aprendizagem, tendo os alunos como elementos mais ativos } \\
\text { neste processo; } \\
\text { O curso procura valorizar os costumes regionais da cidade. Há sempre } \\
\text { algum tipo de celebração para preservar suas datas comemorativas. Há } \\
\text { ainda outros costumes, como o Dia do Professor, a semana da } \\
\text { Contabilidade, feira de livros, distribuição de vales-livro para as escolas da } \\
\text { região, entre outros. } \\
\text { A UEFS realiza ações de extensão, interagindo com a comunidade por meio } \\
\text { de atividades como atendimento gratuito na declaração de IRPF, } \\
\text { contabilidade doméstica, contabilidade do cidadão, e atendimento a } \\
\text { organizações sem fins lucrativos. }\end{array}$ \\
\hline
\end{tabular}


Continuação da Tabela 31

\begin{tabular}{l|l}
\hline Categorias & \multicolumn{1}{c}{ Discurso do Sujeito Coletivo (DSC) } \\
\hline & $\begin{array}{l}\text { Creio que o melhor do curso no DCIS/UEFS encontra-se no passado. A } \\
\text { maioria dos aspectos positivos do curso pode ser creditada aos docentes } \\
\text { que nos antecederam. Estes foram fundamentais no desenvolvimento do } \\
\text { curso, nos aspectos profissional, crítico e conceitual, contribuindo para os } \\
\text { alunos se posicionarem de forma civica, cidadã, politica e ética. Muitos dos } \\
\text { atuais docentes foram alunos daqueles mestres que, junto com os alunos e } \\
\text { apoiados pela gestão, conseguiam desenvolver uma série de eventos } \\
\text { periódicos com temas contábeis modernos, trazendo docentes notáveis do } \\
\text { país para palestras, seminários e conferências. }\end{array}$
\end{tabular}

Curso de Ciências Contábeis: O sujeito coletivo diz que o melhor do curso está no passado, nos docentes pioneiros que fizeram seguidores, mas que hoje o curso encontra-se em decadência, mais parecendo um sistema cartorial, e seus alunos são menos preparados que os de Administração e Economia.
Integração e gestão: $O$ sujeito coletivo diz que o curso não tem um núcleo de docentes com DE, como os demais cursos da UEFS, e que a gestão é ausente, não havendo qualquer grau de integração entre os membros do curso no DCIS e entre estes e a gestão superior.
Hoje, o relacionamento da gestão do curso com o ambiente externo - a sociedade e o mercado profissional - é basicamente nulo. As condições das salas de aula são precárias, sem climatização, às vezes faz muito calor, banheiros sem manutenção adequada e também não há segurança, já tendo ocorrido assaltos dentro do campus. Apesar de tudo isso, a UEFS ainda é uma boa referência na Bahia, devido ao desempenho dos alunos nos exames externos, sendo que no Enade ela geralmente tem ficado entre os dois primeiros lugares no estado.

Dos quatro cursos do DCIS/UEFS, excluindo o curso de Direito, os alunos menos preparados são os de Ciências Contábeis. Há um enorme abismo de cultura e autonomia nesses alunos quando comparados aos de Administração e Economia. A maioria não lê os textos para estudo, e, nas atividades de pesquisa, eles costumam, em geral, plagiar os textos de forma parcial e até integral.

Infelizmente percebo que o sistema de ensino superior no Brasil se transformou em um grande cartório, abrangendo o ensino público e o privado. A minha frustração é grande como acadêmico, por ter me esforçado tanto em buscar qualificações e produção cientifica, e constatar essa realidade cartorial na UEFS e no ensino superior em geral, no país.

Embora tenhamos reitor, pró-reitores, diretores e coordenadores, percebo que a gestão é basicamente ausente. Não percebo qualquer grau de integração entre a gestão, o DCIS, o colegiado, os docentes e os discentes. Os docentes atuam praticamente isolados, mas não porque queremos e sim devido à localização geográfica das salas em módulos (prédios) distintos e distantes. A integração entre a coordenação e docentes acontece casualmente.

Estamos agora em uma fase de reforma da grade curricular. No currículo anterior, de cinco anos, havia um perfil mais voltado para Auditoria, Contabilidade Societária e Contabilidade Gerencial. Com a redução para quatro anos, nós agora estamos tentando criar um novo perfil para o curso.

Há grande dispersão na condução do DCIS e no colegiado do curso na UEFS. A baixa integração existente se deve a práticas anteriores que vêm se repetindo por inércia, mas há alguma integração em grupos de docentes que moram em Feira de Santana.

A direção da UEFS tenta, em geral, dinamizar a IES, porém comete o equívoco de priorizar cursos diurnos em detrimento dos noturnos. Os cursos diurnos têm núcleos de docentes com $D E$ e dedicados ao curso, enquanto o curso de Contábeis não tem. Assim, quando os recursos financeiros são disponibilizados, os cursos que já têm projetos esgotam esses recursos. 
A última dimensão, consistência, contém as 'crenças e valores expostos', que estão descritos nas suas respectivas categorias: COA do Curso na UEFS; Curso de Ciências Contábeis; e Integração e gestão. As suposições básicas foram extraídas de trechos dos DSC, apresentados na Tabela 31, respectivamente, nas suas três categorias.

Há traços de uma COA do curso na UEFS, mas ela é [...] difusa, imprecisa e sem liderança. Não há um núcleo de docentes doutores com DE e com dedicação integral ao curso, nem, também, um projeto para uma pós-graduação. Se existe uma COA do curso na UEFS, ela está adormecida [...], mas [...] ainda há [...] um potencial latente. Um exemplo recente foi o empenho e a vitória de ter realizado o Dinter com a FEA/USP, concorrendo com outras instituições no Brasil. [...] $\mathrm{O}$ curso procura valorizar os costumes regionais da cidade [...] para preservar suas datas comemorativas. Há ainda outros costumes como o Dia do Professor, a semana da Contabilidade, feira de livros, [...] entre outros. [...] a UEFS realiza ações de extensão, interagindo com a comunidade por meio de atividades como [...] declaração de IRPF, contabilidade doméstica, contabilidade do cidadão, e atendimento a organizações sem fins lucrativos.

[...] o melhor do curso no DCIS/UEFS encontra-se no passado. A maioria dos aspectos positivos do curso pode ser creditada aos docentes que nos antecederam, [...] fundamentais no desenvolvimento do curso nos aspectos profissional, crítico e conceitual. [...] Muitos dos atuais docentes foram alunos daqueles mestres que, junto com os alunos e apoiados pela gestão, conseguiam desenvolver [...] eventos periódicos com temas contábeis modernos, trazendo docentes notáveis do país [...]. Hoje, o relacionamento da gestão do curso com o ambiente externo [...] é basicamente nulo. As condições das salas de aula são precárias e [...] não há segurança [...] dentro do campus. [...]. Dos quatro cursos do DCIS/UEFS [...], os alunos menos preparados são os de Ciências Contábeis. Há um enorme abismo de cultura e autonomia nesses alunos quando comparados aos de Administração e Economia. A maioria [...], nas atividades de pesquisa, [...] costuma plagiar os textos de forma parcial e até integral. [...] infelizmente percebo que o sistema de ensino superior no Brasil se transformou em um grande cartório. [...] A minha frustração é grande como acadêmico [...] ao constatar essa realidade cartorial na UEFS e no ensino superior em geral, no país.

Embora tenhamos reitor, pró-reitores, diretores e coordenadores, percebo que a gestão é basicamente ausente. Não percebo qualquer grau de integração entre a gestão, o DCIS, o colegiado, os docentes e os discentes. [...] estamos agora em uma fase de reforma da grade curricular. No currículo anterior, de cinco anos [...], havia um perfil mais voltado para Auditoria, Contabilidade Societária e Contabilidade Gerencial. [...] há grande dispersão na condução do DCIS e no colegiado do curso na UEFS. A baixa integração [...] se deve a práticas anteriores que vêm se repetindo por inércia, mas há alguma [...] em grupos de docentes que moram em Feira de Santana. [...] a direção [...] tenta, em geral, dinamizar a IES, porém comete o equívoco de priorizar cursos diurnos em detrimento dos noturnos. 
De acordo com os DSC, há indícios de que não há integração entre a gestão, o DCIS, o colegiado, os docentes e os alunos. Os docentes reconhecem até que existe uma COA do curso de Ciências Contábeis no DCIS/UEFS, contudo ela está adormecida, porém possui potencial para voltar a crescer. Eles comentam, recordando, que as glórias e o melhor da IES ficaram no passado, cujo apogeu situou-se entre 1998 e 2006, enaltecendo os docentes-ícones que prestaram grande contribuição à instituição. Contudo, reforçam que o relacionamento interno do curso na IES é fraco, e com o ambiente externo é basicamente inexistente. Relatam, em seguida, as condições precárias em que acontece o processo de ensinoaprendizagem do curso, mas ressaltam algumas ações positivas da UEFS na busca de se preservar a cultura regional da cidade onde está instalada, além de ações de extensão na comunidade.

Nota-se uma situação antagônica na UEFS frente aos achados de Denison et al. (2012). Estes autores sustentam que nesta dimensão em análise, estaria a compreensão de que a eficácia das organizações é influenciada fortemente pela coerência e a boa integração do seu ambiente interno, alicerçado em um conjunto de valores fundamentais. Schein (2009) denomina essa conjugação de aspectos de certezas profundas contributivas na formação das suposições básicas compartilhadas, nas quais ele busca explicar, além do que é real ou não nas organizações, a natureza simbólica das atividades humanas em constante interação operacional, destacando relacionamentos, formas de cooperação ou competição e grupos.

Alguns docentes sentem-se frustrados em constatar que, apesar de todo o esforço de qualificação e de buscar o aumento da produção científica, o curso e, em geral, as outras IES do país, transformaram-se em um grande sistema cartorial. Na sequência, os docentes repetem temas já citados como ausência de liderança e gestão; e que a grade curricular do curso está sendo atualizada. Há só um aspecto adicional digno de nota: a integração é mais acentuada entre os docentes que moram em Feira de Santana.

A partir do referencial de Denison et al. (2012), parece que a cultura do curso na UEFS encontra-se frágil e difusa, ainda vivendo das glórias passadas. As características burocráticas e de limitação de poder da administração pública podem até explicar parcialmente o estado em se encontra o curso no DCIS/UEFS, embora possam existir outros meios para se tentar soerguer esse curso e a própria UEFS. 
Nesse caso, as subculturas ou culturas de subgrupos estariam tornando difusa e dispersa a COA do curso do DCIS/UEFS? O grupo de docentes afastados em programas de doutoramento poderia ter criado lacunas na COA do DCIS/UEFS? Pelo menos, estas indagações parecem justificar o fenômeno destacado por Hofstede (2003), segundo o qual, quando há mudanças de um grupo para outro ambiente, este carrega a subcultura com ele. Nesse caso, teoricamente, o retorno do grupo poderia resgatar as lacunas na COA do DCIS/UEFS, complementando-a.

\subsubsection{Resultados e análise do levantamento com os alunos do curso de Ciências Contábeis do DCIS/UEFS}

Nesta subseção são apresentados os resultados do survey realizado com 84 alunos do curso de Ciências Contábeis do DCIS/UEFS, por meio da aplicação de questionários em sala de aula. As respostas foram inseridas no sistema eletrônico QuestionPro, como referido no capítulo 3.

Do conjunto de 84 respondentes, $44(52,38 \%)$ são do sexo feminino e 40 (47,62\%), do sexo masculino. Quanto ao semestre que os alunos estavam cursando, os dados estão apresentados na Figura 12.

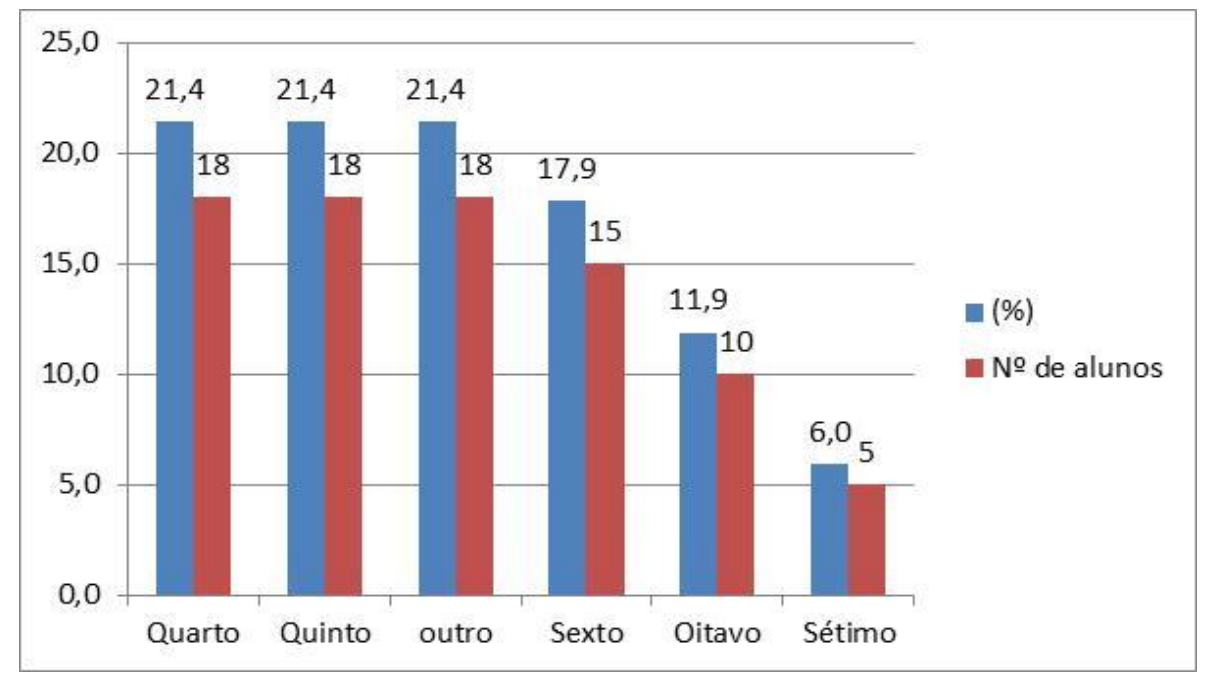




\section{Figura 12. Distribuição dos respondentes por semestre letivo (DCIS/UEFS)}

O perfil das respostas dos alunos à pergunta "Você trabalha, faz estágio ou estuda?", pode ser visto na Figura 13, por meio da qual se observa que 74 alunos $(91,7 \%)$ trabalham ou fazem estágio.

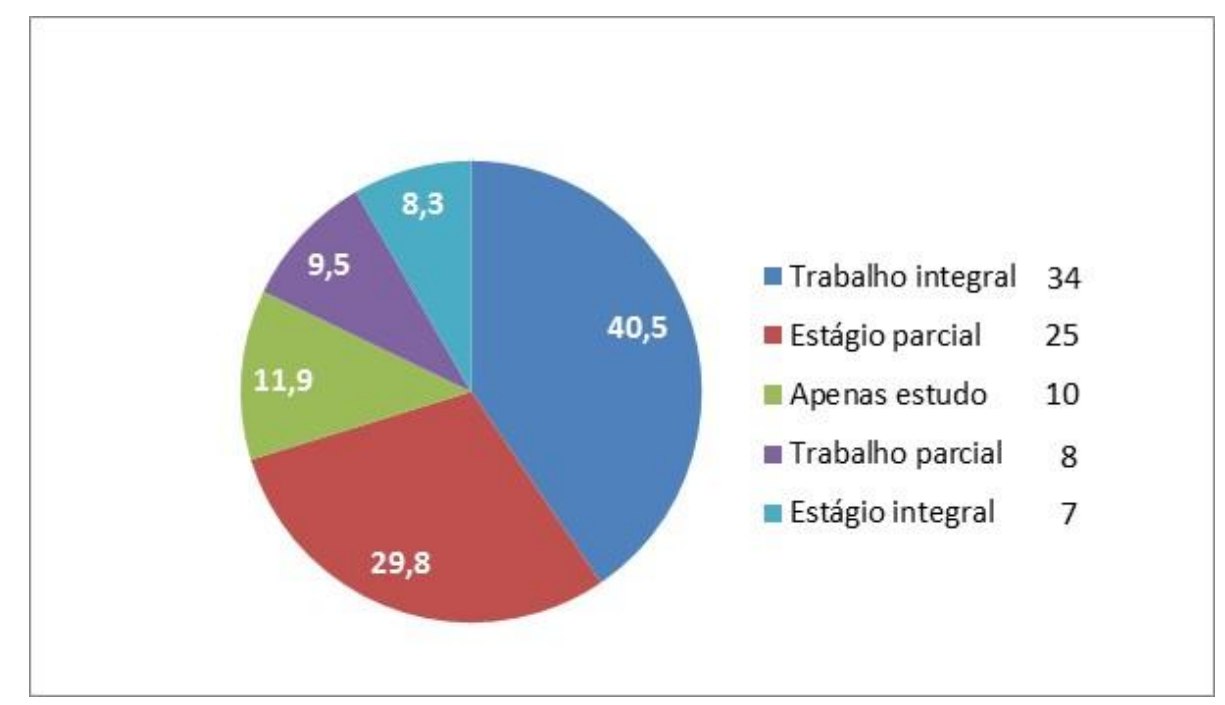

Figura 13. Inserção no mercado de trabalho dos alunos do curso (DCIS/UEFS)

As respostas dos alunos, mostradas na Tabela 32, a seguir, foram obtidas por meio do questionário e dos procedimentos apresentados na seção 3.6 do capítulo 3. Na tabela, as questões estão apresentadas de forma abreviada, por questão de espaço. É oportuno frisar que as 16 questões fechadas do questionário estão formuladas como afirmações. Portanto, ao longo deste capítulo e do próximo, quando houver referência a estas questões, elas podem estar apresentadas das duas formas, como afirmação ou questão. 
Tabela 32

Survey com os alunos do curso de Ciências Contábeis do DCIS/UEFS.

\begin{tabular}{|c|c|c|c|c|c|c|c|c|c|c|c|}
\hline \multirow[t]{2}{*}{ Dimensões } & \multirow{2}{*}{ Questões } & \multicolumn{2}{|c|}{$\begin{array}{c}\text { Discordo } \\
\text { totalmente }\end{array}$} & \multicolumn{2}{|c|}{$\begin{array}{c}\text { Discordo } \\
\text { parcialmente }\end{array}$} & \multicolumn{2}{|c|}{$\begin{array}{l}\text { Nem discordo } \\
\text { nem concordo }\end{array}$} & \multicolumn{2}{|c|}{\begin{tabular}{|c|} 
Concordo \\
parcialmente
\end{tabular}} & \multicolumn{2}{|c|}{$\begin{array}{c}\text { Concordo } \\
\text { totalmente }\end{array}$} \\
\hline & & $\mathbf{N}$ & $\%$ & $\mathbf{N}$ & $\%$ & $\mathbf{N}$ & $\%$ & $\mathbf{N}$ & $\%$ & $\mathbf{N}$ & $\%$ \\
\hline \multirow{4}{*}{ Missão } & Ações da direção indicam que ela segue a missão da IES. & 2 & 2,4 & 15 & 17,9 & 11 & 13,1 & 45 & 53,6 & 11 & 13,1 \\
\hline & Coordenação controla metas e objetivos para assegurar o seu sucesso. & 4 & 4,8 & 26 & 31,0 & 4 & 4,8 & 40 & 47,6 & 10 & 11,9 \\
\hline & Metodologias dos docentes são adequadas aos objetivos do curso e da IES. & 2 & 2,4 & 27 & 32,1 & 6 & 7,1 & 45 & 53,6 & 4 & 4,8 \\
\hline & Práticas docentes adequadas ao que se espera do contador no futuro. & 10 & 11,9 & 29 & 34,5 & 5 & 6,0 & 33 & 39,3 & 7 & 8,3 \\
\hline \multirow{4}{*}{$\begin{array}{c}\text { Adaptabilidade } \\
\text { Externa }\end{array}$} & Desempenho nos exames externos afeta gestão na tomada de decisões & 12 & 14,3 & 12 & 14,3 & 10 & 11,9 & 26 & 31,0 & 24 & 28,6 \\
\hline & Docentes trazem temas práticos do mercado profissional para a sala de aula. & 9 & 10,7 & 27 & 32,1 & 2 & 2,4 & 40 & 47,6 & 6 & 7,1 \\
\hline & Docentes procuram atualizar alunos com realidade do mercado profissional. & 4 & 4,8 & 25 & 29,8 & 2 & 2,4 & 45 & 53,6 & 8 & 9,5 \\
\hline & $\begin{array}{l}\text { Docentes buscam se integrar com alunos na melhoria do ensino- } \\
\text { aprendizagem }\end{array}$ & 7 & 8,3 & 26 & 31,0 & 1 & 1,2 & 44 & 52,4 & 6 & 7,1 \\
\hline \multirow{4}{*}{$\begin{array}{c}\text { Integração } \\
\text { Interna }\end{array}$} & Alunos dispõem de informações suficientes para o bom andamento do curso. & 4 & 4,8 & 34 & 40,5 & 7 & 8,3 & 28 & 33,3 & 11 & 13,1 \\
\hline & Existe integração entre a coordenação e os docentes do curso. & 4 & 4,8 & 23 & 27,4 & 14 & 16,7 & 34 & 40,5 & 9 & 10,7 \\
\hline & Existe uma cultura acadêmica específica no curso de Ciências Contábeis. & 9 & 10,7 & 27 & 32,1 & 12 & 14,3 & 26 & 31,0 & 10 & 11,9 \\
\hline & Eu me sinto motivado para o aprendizado pelos docentes. & 8 & 9,5 & 23 & 27,4 & 10 & 11,9 & 39 & 46,4 & 4 & 4,8 \\
\hline \multirow{4}{*}{ Consistência } & Promessas da coordenação são cumpridas pelas práticas docentes. & 8 & 9,5 & 21 & 25,0 & 19 & 22,6 & 34 & 40,5 & 2 & 2,4 \\
\hline & COA do curso na IES indica o seu compromisso & 5 & 6,0 & 31 & 36,9 & 3 & 3,6 & 35 & 41,7 & 10 & 11,9 \\
\hline & Práticas dos docentes indicam que eles estão integrados com o curso. & 3 & 3,6 & 14 & 16,7 & 7 & 8,3 & 46 & 54,8 & 14 & 16,7 \\
\hline & Integração entre coordenação e docentes aponta sólida liderança. & 9 & 10,7 & 25 & 29,8 & 21 & 25,0 & 27 & 32,1 & 2 & 2,4 \\
\hline
\end{tabular}


Houve maior concentração de escolhas na opção 'concordo parcialmente', em 15 das 16 questões. Contudo, ao se comparar os somatórios das duas opções de concordância com as das outras três opções, percebe-se que em cinco das 16 questões os alunos discordam ou são indiferentes. Esses resultados ocorreram na integração interna e na consistência, com duas questões cada, aparentemente coincidindo com os dados encontrados na FEA. No entanto, o somatório total de discordância e indiferença dessas duas dimensões sugere que os alunos se mostram mais insatisfeitos que o contrário.

Ao considerar as respostas como uma proxy do nível de satisfação dos alunos no estudo de Uprety e Chhetri (2014), comparado com os resultados da avaliação total das dimensões neste trabalho, parece ter havido coerência em apenas uma delas: adaptabilidade externa. De acordo com os resultados encontrados no curso do DCIS/UEFS, em ordem decrescente, os alunos parecem dar mais importância, depois da dimensão citada, apenas à missão. Assim, há indicação de coerência entre os dois estudos em apenas uma dimensão: adaptabilidade externa.

Missão: parece que a maioria dos alunos acredita nas três primeiras afirmações (ações da direção...; controle de metas...; e metodologias dos docentes...). Em contrapartida, a maioria discorda ou tem dúvidas se as práticas docentes são adequadas ao que se espera do contador no futuro. Embora este resultado não seja consistente com os achados de Uprety e Chhetri (2014), ele parece encontrar suporte nos referenciais de Denison et al. (2012), quando estes autores comentam que a missão cria um significado, ao definir um papel social convincente e um conjunto de metas para a organização.

Adaptabilidade externa: a maioria dos alunos acredita em todas as afirmações dessa dimensão, o que é consistente com o estudo de Uprety e Chhetri (2014), e também com uma das questões fundamentais indicadas por Schein (2009) para a sobrevivência de organizações. No entanto, 40,8\% dos alunos, em geral, ainda discordam ou têm dúvidas quanto a essas afirmações.

Integração interna: essa dimensão foi a única em que, de forma geral, a maioria $(52,1 \%)$ dos alunos discorda ou tem dúvidas quanto às afirmações. Este resultado parece revelar, 
segundo Denison et al (2012), que as pessoas que compõem a organização não estão fortemente comprometidas com as suas atividades laborais. Parece, segundo esses autores, que está faltando: capacitação, orientação de equipe e desenvolvimento de capacidades.

Consistência: nessa dimensão pode ser dito que houve uma espécie de "empate técnico", ou seja, em geral, o somatório das opções de concordância foi equivalente ao somatório das outras três opções. Apesar dessa observação, neste estudo essa dimensão ficou em terceiro lugar por ordem de prioridade, portanto parece consistente com o estudo de Uprety e Chhetri (2014), no qual ela também ficou em terceiro lugar. No entanto, ela é uma das dimensões que assegura a satisfação dos alunos na IES.

Em geral, a maioria dos alunos achou positiva a conduta do curso em três das quatro dimensões da COA do curso no DCIS/UEFS. Em ordem decrescente de importância, a maioria dos alunos escolheu: adaptabilidade externa, missão e consistência. O fato de não estar presente a questão ligada à integração interna, segundo Schein (2009), representa um desafio a ser considerado pela IES, caso deseje melhorar seu desempenho, segundo os autores Schein (2009) e Denison et al. (2012).

Na sequência, aparece a questão 17, com o seguinte enunciado: O que você acha que deve mudar no curso para que ele se torne tão atual quanto o dinâmico mercado do contador? As respostas dos alunos estão apresentadas na Tabela 33.

Tabela 33

Escolha dos alunos quanto a mudanças no curso (DCIS/UEFS)

\begin{tabular}{lc}
\hline \multicolumn{1}{c}{ Alternativa } & $\begin{array}{c}\mathbf{N}^{\mathbf{0}} \text { de } \\
\text { respostas }\end{array}$ \\
\hline O curso deveria ter uma prática tão intensa quanto a teoria & 67 \\
Atualização dinâmica da grade curricular & 55 \\
Os docentes deveriam trabalhar mais com problemas e estudos de caso & 51 \\
Incentivo maior à pesquisa & 41 \\
O curso deveria fazer mais eventos com pessoas ou empresas do mercado profissional & 37 \\
\hline
\end{tabular}

A preferência dos alunos concentrou-se nas mudanças das práticas docentes em equilíbrio com a teoria, atualização dos conteúdos curriculares e estudos de casos. Percebe-se ainda que os alunos têm necessidade de serem mais incentivados para a pesquisa e iniciação científica. 
Observa-se, ao comparar as escolhas dos alunos do curso do DCIS com as dos alunos do curso da FEA, uma coincidência nas opções mais escolhidas em primeiro e terceiro lugares, o que sugere uma importância maior desses dois aspectos, que deveriam ser mais explorados pelos docentes.

\subsubsection{Síntese da comparação das percepções dos docentes e discentes (DCIS/UEFS)}

Nesta síntese comparativa, buscou-se confrontar os resultados apurados entre o survey com os alunos e trechos dos DSC, por dimensão, elaborados pelo autor com base nos depoimentos dos docentes do curso do DCIS/UEFS.

Tabela 34

Síntese comparativa entre as percepções dos docentes e discentes sobre a COA do curso de Ciências Contábeis do DCIS/UEFS - BA.

\begin{tabular}{|c|c|c|}
\hline DIMENSÃO & PERCEPÇÃO DOS DOCENTES & PERCEPÇÃO DOS ALUNOS \\
\hline $\mathbf{M}$ & $\begin{array}{l}\text { Há uma missão no DCIS, mas ela não é } \\
\text { seguida. Como não há metas e objetivos, não } \\
\text { há controle por falta de planejamento. Deve } \\
\text { ser feita uma reflexão de quais são os pontos } \\
\text { fortes e fracos para se criar condições para um } \\
\text { melhor nível de qualificação e visibilidade. } \\
\text { Os métodos e práticas, em geral, são } \\
\text { tradicionais, voltados para o mercado. }\end{array}$ & $\begin{array}{l}\text { Embora as avaliações das três primeiras } \\
\text { afirmações sejam de concordância, parece } \\
\text { que esses resultados não combinam tanto } \\
\text { com as percepções dos docentes. Há, } \\
\text { porém, alguma coerência quando a maioria } \\
\text { discorda ou tem dúvidas quanto às práticas } \\
\text { dos docentes serem adequadas ao que se } \\
\text { espera do contador no futuro. }\end{array}$ \\
\hline $\begin{array}{l}\text { Adaptabilidade } \\
\text { externa }\end{array}$ & $\begin{array}{l}\text { A grade curricular está em atualização. O } \\
\text { DCIS apoia eventuais iniciativas de alunos e } \\
\text { docentes que trazem profissionais de fora para } \\
\text { falar de temas atuais do mercado. Esses temas } \\
\text { são também abordados em sala de aula. E há } \\
\text { uma minoria que busca se integrar com os } \\
\text { alunos na melhoria do processo ensino- } \\
\text { aprendizagem. }\end{array}$ & $\begin{array}{l}\text { Nessa dimensão ocorreu a maior coerência } \\
\text { entre alunos e docentes. A maioria dos } \\
\text { alunos optou pela concordância e todas as } \\
\text { afirmações foram escolhidas. Percebe-se, } \\
\text { no entanto, que a maioria dos alunos } \\
\text { parece estar mais satisfeita do que os } \\
\text { docentes, pelo que eles revelam na última } \\
\text { afirmação. }\end{array}$ \\
\hline $\begin{array}{c}\text { Integração } \\
\text { interna }\end{array}$ & $\begin{array}{l}\text { Havia no início maior integração, mas hoje } \\
\text { essa união está frágil. Mesmo com vários } \\
\text { docentes qualificados, não se percebem ações } \\
\text { para promover o seu engajamento. A } \\
\text { percepção da COA do curso está associada a } \\
\text { uma linha de produção em série, no sentido } \\
\text { negativo. O curso tem revelado sinais de } \\
\text { queda na motivação de docentes e alunos. }\end{array}$ & $\begin{array}{l}\text { Dimensão crítica. A maioria }(52,1 \%) \\
\text { discorda ou tem dúvidas quanto às } \\
\text { afirmações, o que parece estar consistente } \\
\text { com a percepção dos docentes. Nota-se que } \\
\text { há pouca crença na existência de uma COA } \\
\text { do curso, e pouca crença no processo de } \\
\text { engajamento, integração e motivação para } \\
\text { o aprendizado. }\end{array}$ \\
\hline
\end{tabular}


Continuação da Tabela 34

\begin{tabular}{|c|c|c|}
\hline DIMENSÃO & PERCEPÇÃO DOS DOCENTES & PERCEPÇÃO DOS ALUNOS \\
\hline Consistência & $\begin{array}{l}\text { Embora haja uma gestão formal, esta não é } \\
\text { percebida/refletida no curso. Há traços de } \\
\text { uma COA do curso, mas ela está difusa e } \\
\text { adormecida. Busca-se valorizar os costumes } \\
\text { da cidade com eventos simultâneos da área } \\
\text { contábil, e existem ações de extensão para a } \\
\text { comunidade. Contudo, a função de liderança } \\
\text { não tem se revelado na condução do } \\
\text { DCIS/UEFS. }\end{array}$ & $\begin{array}{l}\text { Nessa dimensão, a maioria escolheu as } \\
\text { opções de concordância nas duas questões } \\
\text { centrais. Na primeira e quarta questões, } \\
\text { eles optaram pela discordância ou dúvida. } \\
\text { Em geral, predominaram as opções de } \\
\text { concordância, por uma pequena margem } \\
(2,4 \%) \text {, mas não houve tanta consistência } \\
\text { com a percepção dos docentes. }\end{array}$ \\
\hline
\end{tabular}

Pela análise das percepções de docentes e alunos, observa-se que eles parecem guardar coerência na ordem decrescente de importância dada às dimensões: adaptabilidade externa, missão e consistência. E se mostram mais satisfeitos do que os docentes, principalmente quanto às três primeiras afirmações da missão, e em todas as afirmações da adaptabilidade externa. Por meio desse entendimento, apenas houve consistência da primeira e da terceira dimensões com os achados de Uprety e Chhetri (2014) quanto à satisfação dos alunos.

Esses resultados sugerem, aparentemente, que os alunos ainda se mostram satisfeitos com o curso nas duas primeiras dimensões citadas, e que a gestão, junto com os docentes, tem importantes desafios relativos às outras duas dimensões para tentar soerguer o curso.

Na sequência, foram selecionados trechos dos DSC apresentados nas tabelas anteriores, relativos a métodos e técnicas docentes, visando auxiliar na comparação com os referenciais teóricos de práticas docentes, apresentados na seção 3.4.

Desde a sua gênese, o curso de Ciências Contábeis da UEFS teve docentes que eram profissionais de mercado, o que contribuiu para seus traços culturais [...] tecnicistas, profissionais e voltados estritamente para o mercado e a sociedade, e que continua até hoje.

[...] muitos docentes, mormente os da área contábil-financeira, trazem temas atuais do mercado profissional para a sala de aula.

Apesar das desvantagens de o curso ser [apenas] noturno e não ter uma direção atuante, boa parte dos docentes busca apoio de órgãos externos para se qualificar, visando aperfeiçoar o curso e dinamizar a pesquisa e a produção científica, quase inexistente há dez anos.

[...] A maioria dos aspectos positivos do curso pode ser creditada aos docentes que nos antecederam. Estes foram fundamentais no desenvolvimento [...] nos aspectos 
profissional, crítico e conceitual, contribuindo para os alunos se posicionarem de forma cívica, cidadã, política e ética.

[...] Muitos dos atuais docentes foram alunos daqueles mestres que, junto com os alunos e apoiados pela gestão, conseguiam desenvolver uma série de eventos periódicos com temas contábeis modernos, trazendo docentes notáveis do país para [proferir] palestras, seminários e conferências.

Com relação às práticas docentes, referenciadas na seção 3.4, mais precisamente, na Tabela 13, os docentes do curso do DCIS/UEFS parecem ainda estar nas duas ou três primeiras categorias. Contudo, devido à ênfase no aspecto técnico-profissional, os docentes, em geral, concentram-se mais na categoria teórico-profissional, embora pelo menos $50 \%$ dos entrevistados tenham revelado aspectos das demais categorias.

Esta seção é finalizada com elementos para contribuir à resposta da questão da pesquisa (Qual o atual estágio da cultura organizacional acadêmica nas Instituições de Ensino Superior que mantêm graduação em Ciências Contábeis?). Todas as descrições e análises feitas nas seções anteriores foram elaboradas com este objetivo. Os comentários relativos às hipóteses e tese estão tratados na seção 4.3 de fechamento deste capítulo.

A COA do curso de Ciências Contábeis do DCIS/UEFS, pelos vários aspectos apresentados nas quatro dimensões, parece estar atravessando um ciclo de fragilidade, tanto acadêmica como organizacional. Baseado no que se pode extrair dos DSC baseados na fala dos docentes, a COA está atualmente fragmentada, difusa e adormecida, porém latente. Esse motivo parece justificar o ciclo de queda dos níveis de qualidade do desempenho do curso, afetando a sua visibilidade nos cenários local, regional e nacional. As ações de preservação da COA do curso são incipientes na atualidade, embora seus membros tenham conseguido uma evolução crescente e positiva desde a sua implantação até meados dos anos 2000. Além desse referido período do apogeu, merece destaque positivo a concretização do início da realização do projeto DINTER em 2011, com apoio da gestão superior.

Schein (2009) sustenta que a cultura organizacional pode ser mantida, na medida em que seus membros apreendam, solucionem e compartilhem as questões de adaptação externa e integração interna. Os achados de Denison e Mishra (1995) mostram que as suas quatro dimensões da cultura possuem significativa associação positiva sobre a eficácia do 
desempenho de organizações. Desde que intervenções possam ser feitas para melhorar as dimensões da cultura mais afetadas e manter e melhorar as já existentes, a tendência é que o curso volte a se fortalecer, gradativamente, de forma a resgatar e manter a sua credibilidade e visibilidade.

Dos oito trabalhos empíricos apresentados na seção 2.5, seis apresentaram aspectos comuns em seus achados: a característica de que os processos ou dimensões culturais estão relacionados positivamente com melhores resultados no desempenho, incluindo a contribuição de Uprety e Chhetry (2014) que trata da relação entre dimensões da cultura e o nível geral de satisfação dos estudantes. Esses trabalhos destacaram ainda a importância da liderança como um dos elementos que mais influencia a eficácia no desempenho de forma geral.

A verificação empírica propiciada por este trabalho mais o conteúdo dos achados citados no parágrafo anterior poderia ser adotada como premissa fundamental para que o curso do DCIS/UEFS possa redirecionar o seu rumo e tentar resgatar o seu processo de evolução positiva. Considerando ainda, baseado em Hofstede (2003) que o subgrupo de docentes afastados deverá retornar ao curso, resgatando, supostamente, parte da cultura que havia sido extraída da COA do DCIS/UEFS, a situação poderia teórica e parcialmente ser revertida.

Por outro lado, há questões críticas na COA do curso de Ciências Contábeis do DCIS que estão fora do seu controle, tais como:

a) pelo fato de a universidade ser pública, ela é morosa e burocrática na tramitação de assuntos que envolvem tomadas de decisão relevantes, com impacto econômico-financeiro, e os cargos de chefia ou comando possuem um poder discricionário limitado, que se reflete em uma liderança dependente de habilidade política para quem a ocupa. Este resultado está consistente com um dos achados de Schroeder (2010), de que a liderança é determinante para a cultura organizacional e com os achados de Souza Pires e Macêdo (2006);

b) em decorrência do exposto na alínea anterior, é muito difícil o processo de engajamento e integração dos docentes, descritos nos DSC na seção 4.2.2, o qual 'parece consistente com um dos resultados de Locke e Guglielmo (2006), que comentam sobre a importância do papel dos líderes organizacionais no planejamento e implementação de uma mudança planejada, por meio de ações sobre as subculturas (grupo), as quais 
revelaram aspectos positivos significativos, confirmando ser um fator primordial para o sucesso desses tipos de programas; e

c) o conteúdo dos DSC baseados na fala dos docentes revelou ainda que a gestão acadêmica precisa rever cuidadosamente o processo ensino-aprendizagem, porque este se assemelha a uma linha de produção industrial, no sentido negativo do termo, com mais ênfase a traços tecnicistas do que acadêmicos. De acordo com Hoogan e Coote (2013), a forma como as camadas de cultura organizacional, especialmente as normas, artefatos e comportamentos inovadores, medem parcialmente o desempenho da organização parece contribuir para a implantação de formas inovadoras ligadas ao processo ensinoaprendizagem.

Em síntese, se o desempenho de uma instituição de ensino superior depende e é influenciado de forma relevante pela força e solidez da sua cultura organizacional, a redução ou minimização dessa força e solidez da COA implicará na redução ou queda em seu desempenho.

\subsection{Conclusões sobre os resultados da pesquisa (USP e UEFS)}

Nesta seção são reportadas as conclusões deste capítulo. A técnica do DSC permitiu que categorias fossem identificadas, a partir de suas ideias centrais, para cada dimensão da Cultura Organizacional Acadêmica. Ao todo, foram obtidos 14 DSC para o curso da FEA/USP e 12 DSC para o curso do DCIS/UEFS, que permitiram observar as peculiaridades de cada curso.

É preciso considerar e reforçar que as duas IES, embora sejam públicas e estaduais, pertencem a Regiões e estados bem distintos e que as duas universidades, até por consequência, se encontram também em situações bem diferentes. É possível afirmar que o curso da FEA/USP já está consolidado, funcionando em dois períodos e é pioneiro, no Brasil, em implantar os cursos de mestrado e doutorado em Controladoria e Contabilidade. Já o curso do DCIS/UEFS funciona apenas no período noturno, e é possível sugerir que este ainda se encontra em evolução, não possuindo ainda nenhum curso stricto sensu em Contabilidade. 
Por meio de cuidadoso exame dos DSC de ambas as IES, foi possível identificar e extrair trechos assemelhados que parecem comuns aos dois cursos, cujos conteúdos puderam ser organizados e subdivididos em duas partes: uma ligada ao ensino e aprendizagem, e outra ligada ao engajamento e integração dos docentes e à gestão, que são apresentados a seguir.

\section{a) Ensino e aprendizagem.}

Inicialmente, o curso de Ciências Contábeis era visto como instrumental, e a maioria dos docentes era constituída de profissionais de mercado, o que contribuiu para que seus traços culturais possuíssem características profissionais, e mais voltadas para o mercado e a sociedade;

[...] até os anos 2000, os docentes planejavam e davam suas aulas utilizando estilos mais tradicionais, com muita exposição e teorias, contribuindo para aumentar ainda mais a tendência do aluno em adotar uma postura passiva e menos participativa nas aulas;

[...] as universidades atuais perderam aquela imagem sagrada das universidades inglesas e europeias de 700 anos atrás, quando a missão do docente era a busca da verdade e a responsabilidade de passá-la às novas gerações;

[...] creio que o departamento deveria se afastar dessa visão do processo ensinoaprendizagem como se fosse uma linha de produção industrial, no mau sentido, de formar profissionais para o mercado de trabalho;

[...] outro problema que deve ser minimizado no nosso curso, assim como em outras IES públicas no Brasil de hoje, é que boa parte dos docentes possui apenas formação acadêmica, o que se reflete em aulas mais teóricas do que práticas, porém sem o embasamento crítico-reflexivo necessário ao egresso para potencializar sua atuação no mercado e na sociedade.

b) Engajamento e Integração:

Há 20 anos, o engajamento e integração no departamento eram bem melhores do que hoje. Não se trata de saudosismo ou coisas do tipo "na minha época é que era bom", mas não consigo perceber esse processo de engajamento e integração como eu o notava no passado;

[...] geralmente, na atualidade, os docentes cumprem suas atividades, basicamente, isolados;

[...] as atividades da universidade estão um pouco desintegradas, incluindo sua própria estrutura, que conduz a uma individualidade de seus membros, o que é um paradoxo com relação ao significado da palavra universidade. Aqui as faculdades têm vida própria e são isoladas umas das outras;

[...] há uma desvantagem nas IES públicas em relação às IES privadas, que é o aperfeiçoamento moroso da COA, principalmente, quanto ao processo de integração e engajamento dos seus membros. O engajamento é uma das coisas mais dificeis numa universidade pública;

[...] quando estamos na posição de gestores, temos quase que pedir "pelo amor de Deus" para os colegas nos ajudarem nos trabalhos. 
Como se pode observar, em ambos os aspectos, os trechos citados abordam características saudosistas ou críticas. No entanto, parte desses pontos em comum pode ser explicada pelo fato de ambas as IES serem organizações públicas, e, portanto, possuírem características críticas comuns, tais como a burocracia, e limitações do poder de comando, com restrita discricionariedade. Esses pontos são consistentes com os resultados descobertos por Souza Pires e Macêdo (2006), relativos a esse tipo de organização: i) possui cultura burocrática, corporativa e avessa ao empreendedorismo que orienta a prática de gestão; ii) o seu desenho organizacional apresenta formas bastante complexas e níveis hierárquicos múltiplos, demonstrando um paternalismo que gera alto controle de movimentação de pessoal, cargos e comissões; e iii) essas organizações são vulneráveis à interferência política externa.

Quanto aos referidos trechos dos DSC, eles permitem inferir que existem aspectos que precisam ser melhorados, tais como: o caráter profissional do curso, que mais parece uma produção em série industrial, no sentido negativo do termo; a missão da universidade, que hoje não visa mais a 'busca da verdade e a responsabilidade de passá-la às novas gerações’; e o processo de envolvimento, engajamento e integração entre os docentes, que 'é uma das coisas mais difíceis em uma universidade pública'.

Em síntese, o atual estágio da COA, nos dois cursos das duas universidades pesquisadas, apresenta-se em polos diametralmente opostos, ou seja, há força na COA do curso da USP, que se reflete na responsabilidade de manter, no presente, os padrões alcançados no passado e buscar aumentar essa alta reputação e visibilidade do curso no país, na América Latina e em nível global, com orientação estratégica para a internacionalização. Por outro lado, a situação encontrada no curso do DCIS/UEFS é bastante distinta, de acordo com seus docentes. Existe enfraquecimento e fragilidade da sua COA, que vem se mantendo basicamente adormecida e estática, frente às mudanças do ambiente externo, o que se reflete na queda dos níveis de qualidade do curso e dos alunos, e também na motivação dos alunos e até dos docentes.

Há um pequeno trecho de um DSC do curso da FEA/USP que ilustra bem a importância da preservação de sua COA. 
A nossa COA é formada por subculturas; as áreas de Mercado de Capitais, Contabilidade Societária e de Contabilidade Gerencial são um exemplo disso. As crenças, valores e tradições já estão no DNA da COA no departamento, portanto difíceis de serem mudadas, só sendo possíveis aperfeiçoamentos, mantendo-se as coisas boas, úteis e atuais.

O atual estágio da COA nos cursos das duas instituições pesquisadas encontra alguns aspectos críticos comuns. Ambas as universidades possuem características culturais assemelhadas, como alta burocracia, que se traduz em morosidade, relações de poder limitadas, que dependem muito de características pessoais, e falta de carisma de alguns docentes que se sucedem nos cargos de liderança e gestão.

No caso da UEFS, esse aspecto é mais crítico, talvez devido a fatores que estejam fora do controle da administração da autarquia, e que dependem da Secretaria de Educação do Estado. O curso da USP continua sendo a mais importante referência no país, seus docentes possuem a titulação mínima de doutor, e a maioria possui dedicação integral ao curso (RDIDP), enquanto o curso do DCIS/UEFS encontra-se com sinais de queda, de acordo com os seus docentes. Apenas um, dentre eles, possuía regime de dedicação exclusiva (ou integral) na ocasião da pesquisa. Os demais atuavam em regimes parciais. Embora houvesse três doutores no curso, apenas um era doutor em Contabilidade. Quatro docentes estavam afastados, fazendo doutorado, e os demais possuíam titulação de mestre ou especialista. Para eles, o curso do DCIS/UEFS representava uma espécie de complemento de suas atividades laborais.

Parcela majoritária da literatura empírica trouxe duas características em comum: 1) os processos ou dimensões culturais estão relacionados positivamente com melhores resultados no desempenho; e 2) houve destaque para a importância da liderança como um dos elementos que mais influencia a eficácia no desempenho de forma geral.

A verificação empírica proporcionada por este trabalho mais o conteúdo dos achados citados no parágrafo anterior poderiam ser adotados como premissas fundamentais para que o curso do DCIS/UEFS possa redirecionar o seu rumo e tentar resgatar o seu processo de evolução positiva. Considerando ainda, baseado em Hofstede (2003) que o subgrupo de docentes afastados deverá retornar ao curso, resgatando, supostamente, parte da cultura que 
havia sido retirada da COA do DCIS/UEFS, a situação poderia teórica e parcialmente ser revertida.

Espera-se que o objetivo de compreensão da COA tenha sido atingido. Porém, como foram analisadas apenas duas universidades estaduais públicas, é necessária muita cautela no que se refere à generalização dos resultados. A pesquisa apresentou elementos que fornecem evidências, ainda que não conclusivas, de que os resultados decorrentes do desempenho na formação dos estudantes e egressos do curso têm forte dependência da força e solidez da cultura organizacional do curso na IES, força esta materializada na responsabilidade, atitude e empenho de seus membros (docentes) na condução das atividades de ensino e pesquisa.

No curso do DCIS/UEFS, há indicações de que os docentes detenham, parcialmente, as práticas apresentadas na seção 2.4. Foi possível encontrar nos DSC algumas evidências que permitiram fazer associações com a Tabela 14 (síntese das práticas e/ou competências docentes). Porém, em geral, os docentes se identificam com as práticas ligadas à categoria teórico-profissional. No entanto, pelo menos 50\% dos docentes apresentam aspectos das demais categorias, mas parecem buscar se aperfeiçoar, apesar das limitações encontradas. No curso da FEA/USP, a titulação mínima dos docentes é de doutorado, e eles parecem, em geral, deter grande parte das práticas contidas na referida Tabela 14, principalmente as três primeiras.

Por meio da revisão de literatura e da pesquisa no campo empírico, foi possível atingir os objetivos específicos: a) compreender o que é cultura organizacional (CO) e identificá-la em dois cursos de Ciências Contábeis nas duas IES citadas; b) identificar formas e caminhos para compreender, in loco, a cultura organizacional acadêmica existente nas referidas IES; c) identificar práticas docentes associadas com a mudança da COA; e d) identificar alternativas que possam contribuir para o equilíbrio ou adequação entre a COA do curso nas IES e a constante mutação do ambiente profissional externo. Este último parece ter sido atingido na medida em que foram identificados vários DSC, no caso da FEA, que sustentam o alcance deste objetivo. Este ponto é reforçado pelo trecho a seguir.

A trajetória do departamento tem sempre mostrado essa abertura para o novo. Hoje, com o projeto Discovery, busca-se autonomia, internacionalização e uma proximidade maior com a realidade do mercado. Enquanto as IES do país nos enxergam como 
referência, nós pesquisamos as melhores escolas de Contabilidade do ambiente externo, em um processo de internacionalização agora intensificado com o projeto Discovery.

No caso da primeira hipótese: "Quanto mais força e solidez tiver a COA do curso nas respectivas IES, melhores deverão ser os seus resultados em termos de desempenho e visibilidade externa", as descobertas desta tese, tanto as que estão no histórico das duas IES, como as que estão nos DSC elaborados com base nas entrevistas dos docentes, estão alinhadas com quase todos os achados dos referenciais empíricos. No caso da UEFS, os dados apresentados na Tabela 30 (Conceitos do Enade), da seção 4.2.2, evidenciam esse aspecto de forte queda no seu desempenho. Portanto, não foram encontrados motivos para rejeitar esta hipótese.

A segunda hipótese - "A cultura organizacional existente nas IES públicas apresenta baixa adaptabilidade externa, que se reflete em uma baixa integração interna" - parece ter sido verificada, conforme apresentado nos três argumentos a seguir:

Primeiro, o curso da USP, pelo grau de qualificação do seu quadro de docentes e pelo peso da responsabilidade em manter a alta referência e visibilidade do curso, embora consiga se empenhar na criação de mudanças, como a diretriz de internacionalização, não possui alto grau de flexibilidade e capacidade de resposta ao ambiente de negócios (Denison et al., 2012).

O segundo argumento é que a sua burocracia limita as ações, ou seja, de acordo com Denison et al. (2012, p. 7), “organizações com forte senso de propósito e direção geralmente são as menos adaptáveis e mais difíceis de mudar". No caso do curso do DCIS/UEFS, não se pode afirmar que seja uma organização com forte senso de propósito e direção. $\mathrm{O}$ curso parece que vive desconectado da realidade externa, a julgar pelos DSC vistos anteriormente.

Finalmente, o terceiro argumento é que, tanto no curso da FEA quanto no curso do DCIS, o aspecto que mais foi destacado foi a baixa integração entre seus membros docentes. Dois trechos extraídos da citação do DSC consolidado, nessa seção, afirmam "O engajamento é uma das coisas mais difíceis numa universidade pública" e "[...] na posição de gestores, temos que pedir 'pelo amor de Deus' para os colegas nos ajudarem nos trabalhos". 
Quanto à tese, "A cultura organizacional existente nas IES que mantêm graduação em Ciências Contábeis encontra-se difusa em termos de direção, adaptabilidade externa e integração interna", é oportuno trazer à luz alguns elementos vistos nos DSC.

A tese encontra algum respaldo na orientação estratégica do curso da FEA, cuja diretriz de internacionalização pode ser materializada nas ações em andamento, haja vista todo o contexto do Projeto Discovery, além do reconhecimento internacional. Contudo, de acordo com Denison et al. (2012), a direção não se torna eficaz apenas com um forte senso de propósito e direção. Estes aspectos devem ser complementados "por um alto grau de flexibilidade e capacidade de resposta ao ambiente de negócios" (p.7). O trecho a seguir mostra partes dos DSC do curso da FEA que corroboram o fato de que a direção não é percebida como plena.

[...] devido às características da área pública, o poder discricionário de toda a gestão é mínimo, limitado a normas e regras muito rígidas, resultando em uma liderança pouco atuante no contexto operacional.

[...], porém, por sermos uma entidade pública, as ações resultantes da gestão como um todo e o processo de tomada de decisão têm sido muito burocráticos e lentos.

Finalmente, devido ao conjunto formado pelos aspectos descritos anteriormente, adicionados aos argumentos apontados com relação à segunda hipótese, é possível afirmar que a tese foi verificada. 


\section{CONCLUSÕES}

O presente trabalho teve como tema de pesquisa a cultura organizacional de cursos de Ciências Contábeis em Instituições de Ensino Superior (IES) que mantêm este tipo de curso. Foi então criada a denominação Cultura Organizacional Acadêmica (COA). O objetivo geral foi compreender o atual estágio dessa COA em duas IES brasileiras, visando identificar possíveis relações entre essa cultura e os resultados decorrentes do desempenho dessas IES.

A revisão de literatura contemplou as teorias mais relevantes sobre o tema (Schein, 2009; Denison et al,. 2012; e Hofstede, 2003). Buscou-se também identificar a literatura empírica baseada principalmente na abordagem de Schein. Procurou-se ainda mapear o que havia de relevante sobre as práticas e/ou conhecimentos docentes que pudessem ser associados à COA. $\mathrm{Na}$ parte introdutória do referencial, foram abordados aspectos de universidades medievais que, supostamente, ainda estariam presentes nas IES atuais, assim como foi feita uma breve descrição da situação atual do ensino superior no país.

Foram apresentadas duas hipóteses de trabalho: a) Quanto mais força e solidez tiver a COA do curso nas respectivas IES, melhores deverão ser os seus resultados em termos de desempenho e visibilidade externa; e b) A cultura organizacional existente nas IES públicas apresenta baixa adaptabilidade externa, que se reflete em uma baixa integração interna.

A tese que se buscou provar foi a seguinte: "a cultura organizacional existente nas IES que mantêm graduação em Ciências Contábeis encontra-se difusa em termos de direção, adaptabilidade externa e integração interna".

A metodologia utilizada foi predominantemente qualitativa, com base em elementos de etnografia com observação participante, uso de entrevistas, tanto em profundidade quanto semiestruturadas, que foram gravadas para posterior transcrição e edição. Para o tratamento, ordenação e adequação dos conteúdos das entrevistas, utilizou-se a técnica do Discurso do Sujeito Coletivo (DSC), de Lefevre e Lefevre (2012), por meio do software Qualiquantisoft. 
Por se tratar de um estudo em profundidade, o campo empírico compreendeu dois cursos de Ciências Contábeis de duas universidades públicas estaduais, contatadas por acessibilidade. Os cursos pesquisados foram o do Departamento de Contabilidade e Atuária da Faculdade de Economia, Administração e Contabilidade da Universidade de São Paulo (FEA/USP) e o do Departamento de Ciências Sociais Aplicadas da Universidade Estadual de Feira de Santana, na Bahia (DCIS/UEFS).

Na pesquisa foram entrevistados 10 docentes da FEA/USP e oito docentes do DCIS/UEFS. De forma complementar, visando consolidar os achados, foi utilizada a técnica de levantamento com questionário fechado, aplicado a 122 alunos da FEA/USP e 84 alunos do DCIS/UEFS.

Após a coleta e tratamento das informações dos docentes, foram obtidos 28 DSC originais, sendo 14 da FEA/USP e 12 do DCIS/UEFS que estão desdobrados nas quatro dimensões da COA: missão; adaptabilidade externa, integração interna e consistência. Há um DSC de retrospectiva histórica, na visão dos docentes, para cada IES. Foi extraído um DSC de pontos em comum dos DSC das duas IES. Os DSC desdobrados nas dimensões se destinaram a responder à questão da pesquisa: Qual o atual estágio da cultura organizacional acadêmica nas Instituições de Ensino Superior que mantêm graduação em Ciências Contábeis?

$\mathrm{O}$ atual estágio da COA nos cursos das duas universidades pesquisadas encontra-se em polos diametralmente opostos, ou seja, há força na COA do curso da FEA/USP, que se reflete na responsabilidade de manter, no presente, os padrões alcançados no passado, e buscar aumentar a alta referência e visibilidade do curso no país, na América Latina, e em outros países, dada a sua firme orientação estratégica para internacionalização. Por outro lado, a situação encontrada no curso do DCIS/UEFS é oposta. De acordo com seus docentes, o curso desta IES atravessa um período de queda no desempenho e de fragilidade de sua COA, que vem se mantendo basicamente adormecida e estática frente às mudanças do ambiente externo, o que se reflete na queda dos níveis de qualidade do curso e dos alunos, que ingressam em número cada vez menor, e, também, têm influenciado a motivação destes e até dos docentes. 
No caso da UEFS há ainda a evidência de queda de seu desempenho nos exames externos, principalmente no Enade, no qual o conceito da IES caiu de 5, em 2006 para 2, em 2012. Não há esses dados do ENADE para a USP porque esta IES não participa desta avaliação.

A pesquisa apresentou elementos que permitem afirmar que os resultados decorrentes do desempenho do curso nas IES têm forte relação com a força da sua cultura organizacional, materializada na responsabilidade, atitude e empenho de seus membros (docentes e gestores). Por meio da revisão de literatura e da pesquisa no campo empírico, foi possível atender aos objetivos específicos: a) compreender o que é cultura organizacional (CO) e identificá-la em dois cursos de Ciências Contábeis nas duas IES citadas; b) identificar formas e caminhos para compreender, in loco, a cultura organizacional acadêmica existente nas referidas IES; c) identificar práticas docentes associadas com a mudança da COA; e d) identificar caminhos e alternativas que permitissem contribuir para o equilíbrio ou adequação entre a COA do curso nas IES e a constante mutação do ambiente profissional externo.

Quanto às hipóteses, é possível afirmar que ambas não foram rejeitadas pelo exposto a seguir. A primeira hipótese não foi rejeitada considerando que a maioria dos referenciais empíricos apresenta duas características comuns em seus achados: 1) os processos ou dimensões culturais estão relacionados positivamente com melhores resultados no desempenho; e 2) houve grande destaque para a importância da liderança como um dos elementos da cultura organizacional que mais influencia a eficácia no desempenho de forma geral. Portanto, quanto mais força houver nos elementos da COA, maiores e melhores deverão ser os seus resultados em termos de desempenho e imagem no mercado profissional e na sociedade.

A segunda hipótese não foi rejeitada com base nas seguintes razões: i) embora o curso da FEA, pelo grau de qualificação do seu quadro docente e pela responsabilidade de seus membros em manter a alta referência e visibilidade do curso, consiga se empenhar na criação de mudanças como a diretriz de internacionalização, não se constatou alta flexibilidade e rápida capacidade de resposta ao ambiente profissional; ii) sua burocracia limita as ações, ou seja, de acordo com Denison et al. (2012, p. 7), “organizações com forte senso de propósito e direção geralmente são as menos adaptáveis e mais difíceis de mudar", e o curso do DCIS/UEFS não possui esta última característica; a julgar pelos DSC, parece que o curso vive 
isolado no seu ambiente interno; e iii) em ambos os cursos (nas suas IES), o aspecto que mais foi destacado foi o baixo engajamento e integração interna entre os seus membros, mormente os docentes.

\section{Quanto à tese - "A cultura organizacional existente nas IES que mantêm graduação em Ciências Contábeis encontra-se difusa em termos de direção, adaptabilidade externa e integração interna" -, é oportuno trazer à luz alguns elementos percebidos nos DSC.}

A tese encontra algum respaldo na orientação estratégica do curso da FEA, cuja diretriz de internacionalização pode ser materializada nas ações em andamento, incluindo o Projeto Discovery. Contudo, reiterando a afirmação de Denison et al. (2012), a liderança na gestão não se torna eficaz apenas com um forte senso de propósito e direção. Estes devem ser complementados "por um alto grau de flexibilidade e capacidade de resposta ao ambiente de negócios" (p.7).

Tendo em vista o conjunto de argumentos formado pela descrição dos aspectos acima, adicionado aos argumentos relativos à segunda hipótese, é possível afirmar que a tese pôde ser verificada.

Um diferencial deste trabalho é poder disponibilizar para o meio acadêmico, em particular para as IES que mantêm curso de graduação em Ciências Contábeis, revelações de maior profundidade sobre o que parece ser o inconsciente coletivo dos membros acadêmicos deste curso sobre a sua cultura organizacional. Isso propiciou a exposição de aspectos positivos e críticas sobre a evolução da COA de seus cursos (aqui entendidos como oportunidades de melhoria) que podem contribuir para que as IES aumentem a qualificação e a força de sua cultura, com consequências diretas no desempenho e nos resultados gerais.

Concluindo, quanto maior for a força, solidez e qualificação da cultura organizacional acadêmica de um curso de Ciências Contábeis de uma IES, maiores e melhores tenderão a ser os resultados em termos de qualidade, atualidade e visibilidade do curso, incluindo os seus egressos, na sociedade e no mercado profissional.

Como limitações desta pesquisa, podem ser consideradas: i) as duas IES tratadas pelo estudo, embora sejam públicas e estaduais e, por esta razão, possuam características 
semelhantes, estão em situações qualitativas bastante distintas, o que não permite generalizar as conclusões (o curso da FEA/USP possui dois turnos, enquanto o da UEFS só possui o turno noturno); e ii) o afastamento de docentes importantes na UEFS para programas de doutorado (incluindo o Dinter) pode ter provocado algum viés na interpretação dos DSC dessa IES.

Diante dos resultados apresentados nesta tese, recomenda-se para outros pesquisadores: i) investigar este tema também em IES privadas e em outros cursos da área de Ciências Sociais Aplicadas; e ii) adotar uma combinação proporcional de metodologias qualitativas e quantitativas e um recorte longitudinal, que propiciem encontrar resultados mais robustos. 


\section{REFERÊNCIAS}

Abbagnano, N. (2007). Dicionário de Filosofia (5a ed.). (I. C. Benedetti, Trad.). São Paulo: Martins Fontes. (Obra original publicada em 1971).

Adler, R. W., Withing, R. H., \& Wynn-Williams, K. (2008). The influence of Business Case Studies on Learning Styles: an Empirical Investigation. Accounting Education: an International Journal, 17(2), 113-128.

Albrecht, W. S., \& Sack, R. J. (2000). Accounting education: Charting the course through a perilous future (Vol. 16). Sarasota, FL: American Accounting Association.

Alfonso-Goldfarb, A. N. A., \& Ferraz, M. H. (2002). Raízes históricas da difícil equação institucional da ciência no Brasil. São Paulo em perspectiva, 16(3), 03-14.

Alves-Mazzotti, A. J. (2008). Representações sociais: aspectos teóricos e aplicações à Educação. Revista Múltiplas Leituras, 1(1), 18-43.

Andere, M. A., \& Araújo, A. M. P. de (2008). Aspectos da formação do professor de ensino superior de Ciências Contábeis: uma análise dos programas de pós-graduação. Revista de Contabilidade \& Finanças, 19(48), 91-102.

Angrosino, M. (2009). Etnografia e observação participante (J. Fonseca, Trad.). - Porto Alegre: Artmed.

Association to Advance Collegiate Schools of Business [AACSB] (2013). Publications:

White papers. Recuperado em 09 outubro, 2013, de http://www.aacsb.edu/publications/whitepapers/

Bardin, L. (1977). Análise de conteúdo. Lisboa: Edições 70.

Barney, J. B. (1986). Organizational culture: can it be a source of sustained competitive advantage? Academy of Management Review, 11(3), 656-665.

Barreyro, G. B., \& Rothen, J. C. (2008). Para uma história da avaliação da Educação Superior Brasileira: análise dos documentos do PARU, CNRES, GERES e PAIUB. Avaliação: Revista da Avaliação da Educação Superior, 13(1), 131-152.

Borg, W. R., \& Gall, M. D. (1979). Educational research: an introduction (3rd ed.). New York: Longman Inc.

Brown, A. D. (1998). Organizational culture (2nd ed.). London: Financial Times Pitman.

Caena, F. (2011). Teachers' core competences: requirements and development. Education and Training 2020. Thematic Working Group 'Professional Development of Teachers'.

European Commission. Recuperado em 07 outubro, 2013, de http://ec.europa.eu/education/school-education/doc/competences en.pdf 
Cameron, K. S., \& Quinn, R. E. (1999). Diagnosing and changing organizational culture: Based on the competing values framework. New York: Addison-Wesley.

Castro, M. H. M., \& Leite, E. M. (2006). Educação no Brasil: atrasos, conquistas e desafios. In P. Tafner (Ed.). Brasil: o estado de uma nação (Cap. 3). Brasília: IPEA.

Choudhry, R. M., Fang, D., \& Mohamed, S. (2007). The nature of safety culture: a survey of the state-of-the-art. Safety Science, 45(10), 993-1012.

Conselho Federal de Contabilidade (2015). Agência de Notícias. Recuperado em 14 outubro, 2015, de http://www.portalcfc.org.br/noticia.php?new=20820.

Cornachione, E. B., Jr. (2004). Tecnologia da educação e cursos de ciências contábeis: modelos colaborativos virtuais. Tese de Livre-docência, Faculdade de Economia, Administração e Contabilidade, Universidade de São Paulo, SP, Brasil.

Correia, A. (1950). A universidade medieval. Revista da Faculdade de Direito da Universidade de São Paulo, 45, 292-329

Cunha, L. A. (2004). Desenvolvimento desigual e combinado no ensino superior: Estado e mercado. Educação \& Sociedade, 25(88), 795-817.

DaMatta, R. (1986). Exploração: um ensaio de sociologia interpretativa. Rio de Janeiro: Rocco.

Davis, S. M. (1984). Managing corporate culture. Cambridge, MA: Ballinger Publishing Company.

Demo, P. (2004). Universidade, aprendizagem e avaliação: horizontes reconstrutivos (3a ed.). Porto Alegre: Mediação.

Denison, D; Hooijberg, R; Lane, N., \& Lief, C. (2012). A força da cultura organizacional nas empresas globais: como conduzir mudanças de impacto e alinhar estratégia e cultura. (E. Furmankiewicz, Trad.). Rio de Janeiro: Elsevier.

Denison, D., \& Mishra, A. K. (1995). Toward a theory of organizational culture and effectiveness. Organization Science, 6(2), 204-223.

Durand, T. (1998). Forms of incompetence. Proceedings of the International Conference on Competence-based Management, Oslo, Norway, 4.

Faculdade de Economia, Administração e Contabilidade da USP. (2015a). Perfil, missão e valores. Recuperado em 02 setembro, 2015, de http://www.portalfea.fea.usp.br/contabilidade/perfil-missao-valores.

FEA/USP. (2015b). História e Mercúrio. Recuperado em 10 setembro, 2015, de https://www.portalfea.fea.usp.br/fea/historia-e-mercurio.

FEA/USP. (2015c). Pessoas. Corpo docente. Recuperado em 29 outubro, 2015, de https://www.portalfea.fea.usp.br/contabilidade/pessoas. 
Fleury, M. T. L. (1996). O desvendar a cultura de uma organização: uma discussão metodológica. In M. T. L. Fleury, \& R. M. Fischer (Orgs.). Cultura e poder nas organizações (2a ed.). São Paulo: Atlas.

Foucault, M. (2010). A arqueologia do saber (7a ed.). (L. F. B. Neves, Trad.). Rio de Janeiro: Forense Universitária. (Obra original publicada em 1969).

Freitas, M. E. de (2007). Cultura organizacional: evolução e crítica. São Paulo: Thomson Learning.

Freitas, S. C. de (2012). An exploratory study on ENADE evaluation report utilization and its impact on undergraduate accounting program performance in Brazil. Doctoral Thesis, Universidade de São Paulo, SP, Brasil.

Hofstede, G. (2003). Culturas e organizações: compreender a nossa programação mental (1a ed.). (A. Fidalgo, Trad.). Lisboa: Edições Sílabo.

Hogan, S. J., \& Coote, L. V. (2014). Organizational culture, innovation, and performance: A test of Schein's model. Journal of Business Research, 67(8), 1609-1621.

Instituto Nacional de Estudos e Pesquisas Educacionais Anísio Teixeira (2010). Resultados do Enade de 2006. Recuperado em 04 novembro, 2015, de

http://portal.inep.gov.br/Enade/resultados.

INEP (2012). Resultados do ENADE de 2009. Recuperado em 18 maio, 2012, de http://portal.inep.gov.br/Enade/resultados.

INEP (2013). Resultados do ENADE de 2012. Recuperado em 08 outubro, 2013, de http://portal.inep.gov.br/Enade/resultados.

INEP (2014a). Censo da Educação Superior. Recuperado em 03 junho, 2014, de http://portal.inep.gov.br/web/censo-da-educacao-superior.

INEP (2014b). Palestra sobre Resultados do Censo da Educação Superior 2012. Recuperado em 01 julho, 2014, de http://portal.inep.gov.br/web/censo-da-educacao-superior/encontronacional.

INEP (2015a). Ações internacionais. Programme for International Student Assessment (PISA) 2012. Recuperado em 13 outubro, 2015, de http://download.inep.gov.br/acoes internacionais/pisa/resultados/2013/country note brazil pisa 2012.pdf

Jodelet, D. (2001). Representações sociais: um domínio em expansão. In D. Jodelet (Org.) As representações sociais (pp. 17-44). Rio de Janeiro: EdUERJ.

Keyton, J. (2005). Communication and organizational culture. A key to understanding work experiences. Thousand Oaks, CA: Sage. 
Lefevre, F., \& Lefevre, A. M. (2005). Discurso do sujeito coletivo: um novo enfoque em pesquisa qualitativa (desdobramentos) (2a ed.). Caxias do Sul: EdUCS.

Lefevre, F., \& Lefevre, A. M. (2012). Pesquisa de representação social: um enfoque qualiquantitativo. A metodologia do discurso do sujeito coletivo (2a ed.). Brasília: Liberlivro.

Lin, Z. J., Xiong, X., \& Liu, M. (2005). Knowledge base and skill development in accounting education: evidence from China. Journal of Accounting Education, 23(3), 149-169.

Locke, M. G., \& Guglielmino, L. (2006). The influence of subcultures on planned change in a community college. Community College Review, 34(2), 108-127.

Louis, M. R. (1985). An investigator's guide to workplace culture. In P. J. Frost, L. F. Moore, M. R. Louis, C. C. Lundberg, \& Martin, J. (Ed). Organizational culture (pp. 73-93). Newbury Park, CA: Sage.

Marshall, P. D., Dombrowski, R. D., Garner, R. M., \& Smith, K. S. (2010). The Accounting Education Gap. The CPA Journal, 80(6), 8-10

Martins, G. A., \& Theóphilo, C. R. (2009). Metodologia da investigação científica para ciências sociais aplicadas (2a ed.). São Paulo: Atlas.

McCowan, T. (2007). Expansion without equity: An analysis of current policy on access to higher education in Brazil. Higher Education, 53(5), 579-598.

Ministério da Educação (2014). Dados sobre a quantidade de cursos de Contabilidade no Brasil por Estado. Recuperado em 21 maio, 2014, de www.emec.mec.gov.br.

Moscovici, S. (1975). La Psychanalyse, son image et son public (2ème ed.). Paris: Presse Universitaire de France.

Motoyama, S. (2006). USP 70 anos: imagens de uma história vivida. São Paulo: EdUSP.

Motoyama, S., Souza, R. de, Rocha, R. R., \& Santos, W. G. dos (2011). História da Universidade de São Paulo - Apontamentos Historiográficos. Revista Cultura e Extensão USP, 5, 9-17.

Motta, F. C. P. (2008). Cultura nacional e cultura organizacional. Revista da ESPM, 2(2), 17 23.

Ott, J. S. (1989). The organizational culture perspective. Pacific Grove, CA: Brooks/Cole.

Ouchi, W. (1988). Teoria Z: como as empresas podem enfrentar o desafio japonês (10a ed.). (A. B. Simões, Trad.). São Paulo: Nobel.

Peleias, I. R., Silva, G. P. D., Segreti, J. B., \& Chirotto, A. R. (2007). Evolução do ensino da contabilidade no Brasil: uma análise histórica. Revista Contabilidade \& Finanças, 30(número especial), 19-32. 
Pereira, L. C. B. (1997). A reforma do Estado dos anos 90: lógica e mecanismos de controle (Vol. 1). Brasília: Ministério da Administração Federal e Reforma do Estado [MARE].

Perkins, J. A. (1972). Organization and functions of the university. The Journal of Higher Education, 43(9), 679-691.

Pettigrew, A. M. (1979). On studying organizational cultures. Administrative Science Quarterly, 2(4), 570-581.

Pimenta, S. G., \& Anastasiou, L. G. C. (2011). Docência no ensino superior (5a ed.). São Paulo: Cortez.

Rait, R. S. (2007). Life in the medieval university. Cambridge: Cambridge University Press. (Original edition in 1912). Recuperado em 29 maio, 2014, de http://www.gutenberg.org/files/20958/20958-h/20958-h.htm

Santos, N. D. A. (2012). Determinantes do desempenho acadêmico dos alunos dos cursos de ciências contábeis. Tese de Doutorado, Universidade de São Paulo, SP, Brasil.

Schein, E. H. (1984). Coming to a New Awareness of Organizational Culture. Sloan Management Review, 25(2), 3-16.

Schein, E. H. (1985,1992). Organizational Culture and Leadership. San Francisco: JosseyBass.

Schein, E. H. (2004). Organizational Culture and Leadership (3rd ed.). San Francisco: JosseyBass.

Schein, E. H. (2007). Guia de sobrevivência da cultura corporativa (2a ed.). (M. Braga, Trad.). Rio de Janeiro: José Olympio.

Schein, E. H. (2009). Cultura organizacional e Liderança. (A. B. Brandão, Trad.). São Paulo: Atlas.

Schroeder, P. J. (2010). A Model for Assessing Organizational Culture in Intercollegiate Athletic. Journal of Issues in Intercollegiate Athletics, 3, 98-118.

Silva, L. D., \& Fadul, E. (2010). A produção científica sobre cultura organizacional em organizações públicas no período de 1997 a 2007: um convite à reflexão. Revista de Administração Contemporânea, 14(4), 651-669.

Smircich, L. (1983). Concepts of culture and organizacional analysis. Administrative Science Quarterly, 28(3), 339-358.

Souza Campos, E. de (2004). História da Universidade de São Paulo. São Paulo: EDUSP.

Souza Pires, J. C. de, \& Macêdo, K. B. (2006). Cultura organizacional em organizações públicas no Brasil. Revista de Administração Pública, 40(1), 81-105. 
Spink, M. J. P. (1993). O conceito de representação social na abordagem psicossocial. Cadernos de Saúde Pública, 9(3), 300-308.

Srour, R. H. (2005). Poder, cultura e ética nas organizações: o desafio das formas de gestão. Rio de Janeiro: Elsevier.

Tardif, M. (2008). Saberes docentes e formação profissional (9a ed.). Petrópolis: Vozes.

Tierney, W. G. (1988). Organizational culture in higher education: Defining the essentials. The Journal of Higher Education, 59(1), 2-21.

Turner, K. F., Reed, R. O., \& Greiman, J. (2011). Accounting Education in Crisis. American Journal of Business Education, 4(12), 39-44

Uderman, S. (2006). Padrões de Organização Industrial e Políticas de Desenvolvimento Regional: Uma análise das estratégias de industrialização na Bahia. Tese de Doutorado, Universidade Federal da Bahia, Salvador, BA, Brasil.

Universidade Estadual de Feira de Santana. (2015a). Sua história. Recuperado em 10 setembro, 2015, de http://www.uefs.br/portal/a-universidade/sua-historia

UEFS. (2015b). ASPLAN. PDI 2011-2015. Recuperado em 10 setembro, 2015, de http://www.uefs.br/portal/assessorias/asplan/menus/pdi-uefs/PDI\%20Final.pdf/view

UEFS. (2015c). Cursos de graduação. Recuperado em 10 setembro, 2015, de http://www.uefs.br/portal/ensino/graduacao/cursos/

UEFS. (2015d). Cursos de pós-graduação. Recuperado em 10 setembro, 2015, de http://www.uefs.br/portal/ensino/pos-graduacao/cursos/

UEFS. (2015e). Resolução CONSEPE 86/2009 - Normas de Regulamentação do Regime de Trabalho. Recuperado em 30 novembro, 2015, de http://www.uefs.br/portal/downloads/resolucoes/consepe/2009/resolucao-consepe-0862009.pdf/view

Universidade de São Paulo (2015a). Universidade de São Paulo. 80 anos de excelência. Recuperado em 02 setembro, 2015, de http://www5.usp.br/institucional/a-usp/historia/.

USP (2015b). CERT. Comissão Especial de Regimes de Trabalho. Recuperado em 30 novembro, 2015, de http://www.usp.br/cert/outros-regimes.

Uprety, R., \& Chhetri, S. B. (2014). College Culture and Student Satisfaction. Journal of Education and Research, 4(1), 77-92 